UNIVERSIDADE DE SÃO PAULO

ESCOLA DE COMUNICAÇÕES E ARTES

WESLEY AUGUSTO NOGUEIRA

À venda em todas as bancas: relação entre produção e circulação de livros colecionáveis comercializados pela Editora Abril na década de 1970. 


\section{WESLEY AUGUSTO NOGUEIRA}

\section{À venda em todas as bancas: relação entre produção e circulação de livros colecionáveis comercializados pela Editora Abril na década de 1970}

Tese apresentada à Escola de Comunicações e Artes da Universidade de São Paulo para obtenção do título de Doutor em Ciência da Informação.

Área de concentração: Cultura e Informação

Orientadora: Profa. Dra. Giulia Crippa 
AUTORIZO A REPRODUÇÃO TOTAL OU PARCIAL DESTE TRABALHO, POR QUALQUER MEIO CONVENCIONAL OU ELETRÔNICO, PARA FINS DE ESTUDO E PESQUISA, DESDE QUE CITADA A FONTE.

\section{Catalogação na Publicação \\ Serviço de Biblioteca e Documentação \\ Escola de Comunicações e Artes da Universidade de São Paulo \\ Dados inseridos pelo(a) autor(a)}

Nogueira, Wesley Augusto

A venda em todas as bancas: relação entre produção e circulaçăo de livros colecionáveis comercializados pela

Editora Abril na década de 1970 / Wesley Augusto Nogueira. -

- São Paulo: W. A. Nogueira, 2018.

262 p.: il.

Tese (Doutorado) - Programa de Pós-Graduação em Ciência da Informação - Escola de Comunicaçōes e Artes / Universidade de São Paulo.

Orientadora: Giulia Crippa

Bibliografia

1. Mercado editorial brasileiro 2. Livros colecionáveis

3. Editora Abril 4. História do Livro 5. Produção e circulação da informação I. Crippa, Giulia II. Título.

CDD 21.ed. - 020

Elaborado por Sarah Lorenzon Ferreira - CRB-8/6888 
Nome: Wesley Augusto Nogueira

Título: À venda em todas as bancas: relação entre produção e circulação de livros colecionáveis comercializados pela Editora Abril na década de 1970

Tese apresentada ao Programa de Pós-Graduação em Ciência da Informação da Escola de Comunicações e Artes da Universidade de São Paulo para obtenção do título de Doutor em Ciência da Informação.

Aprovado em:

Banca Examinadora

Prof. Dr.

Julgamento:

Prof. Dr.

Julgamento:

Prof. Dr.

Julgamento:

Prof. Dr.

Julgamento:

Prof. Dr.

Julgamento:

Prof. Dr.

Julgamento:
Instituição:

Assinatura:

Instituição:

Assinatura:

Instituição:

Assinatura:

Instituição:

Assinatura:

Instituição:

Assinatura:

Instituição:

Assinatura: 


\section{DEDICATÓRIA}

À minha companheira de vida, que soube compreender e me apoiar em todos os momentos. Muito obrigado, meu amor!

À minha mãe, por tudo!

À minha família, por estar sempre por perto! 


\section{AGRADECIMENTOS}

Há muito a se agradecer quando se faz uma tese. Nenhum trabalho acadêmico é uma atividade solitária. Agradeço a todos que, de alguma forma, contribuíram para o resultado deste trabalho. Muito obrigado!

À Giulia Crippa, pela orientação e paciência de sempre.

Aos professores Marco Antônio de Almeida e Nelson Schapochnik pela participação e valiosas sugestões em minha qualificação.

Aos professores Aníbal Bragança, Alessandra El Farr, Marisa Midori e Sandra Reimão, pela cordialidade e disponibilidade em aceitar avaliar este trabalho.

Aos meus queridos amigos Marcos e Simone, pelas leituras e sugestões sempre pertinentes.

Ao Andre e à Mariany, companheiros até os últimos momentos da finalização do estudo. Obrigado pela força!

À CAPES (Coordenação de Aperfeiçoamento de Pessoal de Nível Superior), pelo auxílio financeiro a esta pesquisa. 
De los diversos instrumentos del hombre, el más asombroso es, sin duda, el libro. Los demás son extensiones de su cuerpo. 


\section{RESUMO}

A tese que se apresenta tem por objetivo compreender o vínculo entre o extraordinário volume de vendas de obras de cunho erudito (literatura clássica, filosofia e teatro) em bancas de jornais e a estrutura editorial, publicitária e distributiva de uma grande empresa de comunicação. Para estudar a questão, estabelecemos: 1) as condições histórico-sociais que permitiram o crescimento de uma pequena editora, fundada por estrangeiros em São Paulo, capital, no final dos anos $1940 ; 2)$ as características materiais e textuais das publicações e sua intrínseca relação como condicionante do perfil de público a que eram destinadas; 3 ) - papel da máquina publicitária da Editora Abril e a competente capacidade de concepção e difusão de discursos promocionais, com eficaz teor persuasivo a segmentos específicos de consumidores; 4) as estratégias de distribuição editorial através das bancas de jornais, um canal distinto do legitimado espaço das livrarias. Conclui-se que, tendo em perspectiva um público pouco familiarizado com esse tipo de produto cultural; um país com precária estrutura produtiva para impressão de livros; um setor editorial com baixa tiragem média; e o reduzido hábito de leitura entre a população, os aspectos estabelecidos se coadunaram de maneira a possibilitar que o fenômeno alta tiragem e venda de livros ditos de "alta cultura" se efetivasse.

Palavras-chave: Mercado editorial brasileiro. Livros colecionáveis. Editora Abril. História do Livro. Produção e circulação da informação. 


\begin{abstract}
The aim of this thesis is to understand the link between the extraordinary volume of sales of scholarly works (classical literature, philosophy and theater) in newsstands and the editorial, advertising and distributive structure of a large communication company. To study the question, we established: 1) the social-historical conditions that allowed the growth of a small publishing house, founded by foreigners in the city of São Paulo, in the late 1940s; 2) the material and textual characteristics of the publications and their intrinsic relation as conditioning of the public profile to which they were destined; 3 ) the role of Editora Abril advertising machine and the ability to design and disseminate promotional speeches with effective persuasive content for specific segments of consumers; 4) the strategies of editorial distribution through newsstands, a distinct channel from the legitimate space of bookstores. It is concluded that, having in perspective an unfamiliar audience with this type of cultural product; a country with a poor production structure for book printing; an editorial sector with low average circulation; and the reduced habit of reading among the population, the established aspects were in line with each other so as to enable the high phenomenon of "high culture" books to be produced and sold.
\end{abstract}

Keywords: Brazilian publishing market. Collectible Books. Editora Abril. History of the Book. Information production and circulation. 


\section{SUMÁRIO}

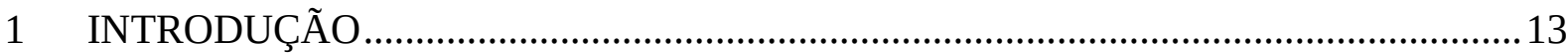

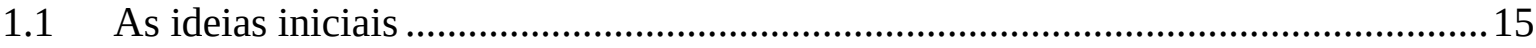

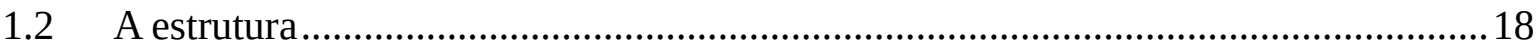

1.3 Métodos e procedimentos .....................................................................................2

2 A HISTÓRIA DE UM MILANÊS NOVAIORQUINO NO PAÍS ONDE NINGUÉM LÊ:

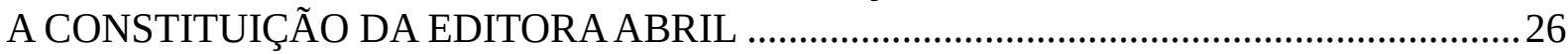

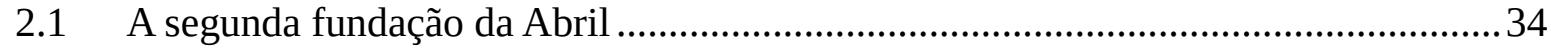

2.2 Dominando o ciclo: editora, gráfica e distribuidora .......................................................39

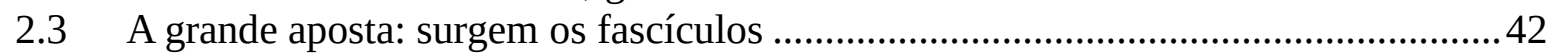

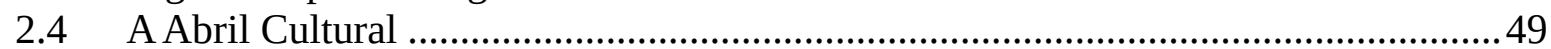

3 DO PROJETO À MATERIALIDADE ...................................................................5

3.1 A euforia econômica faz surgir o público: educação como meio de ascensão ............60

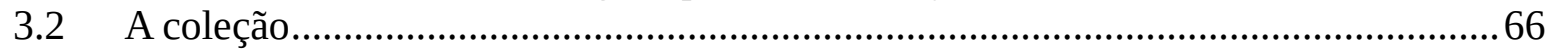

3.3 Uma coleção imortal ............................................................................................ 73

3.4 "Os Pensadores": ou sobre como transformar clássicos da filosofia em best-sellers 99

3.5 Teatro Vivo: o último grande espetáculo da década nas bancas de jornais ...............113

4 O ADUBO QUE FEZ A ÁRVORE CRESCER: PROPAGANDA E PÚBLICO ............131

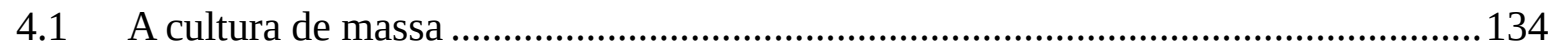

4.2 O pulo do gato de Victor Civita .......................................................................138

4.3 A relação entre consumo e identidade ........................................................................ 140

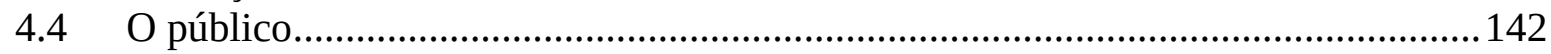

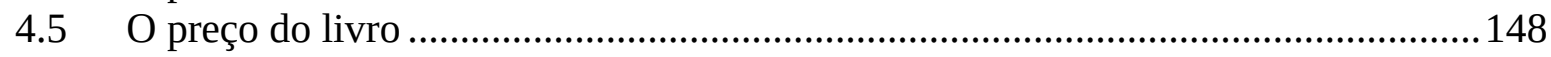

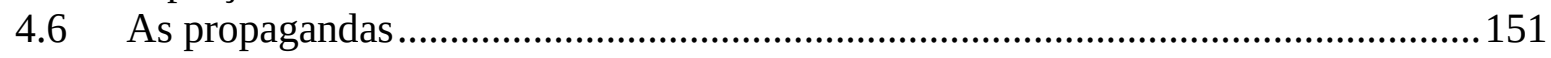

4.7 As coleções da Abril Cultural: a publicidade e seu discurso ......................................156

4.7.1 Os Imortais da Literatura Universal .............................................................160

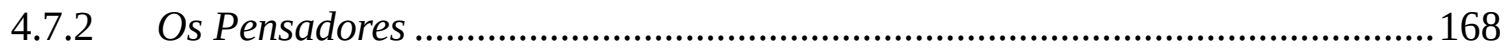

4.7.3 Teatro Vivo ........................................................................................ 174

5 À VENDA EM TODAS AS BANCAS: A CIRCULAÇÃO BIBLIOGRÁFICA EM

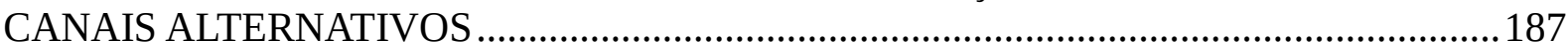

5.1 Dos pequenos jornaleiros às bancas de jornais .........................................................187

5.2 Qual o lugar dos livros? .....................................................................................194

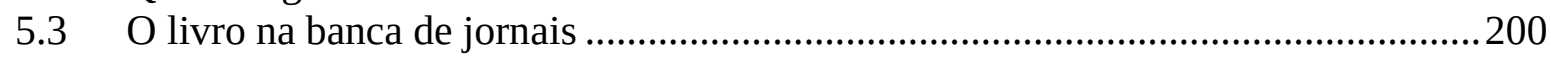

5.4 Outras modalidades alternativas de circulação ......................................................2210

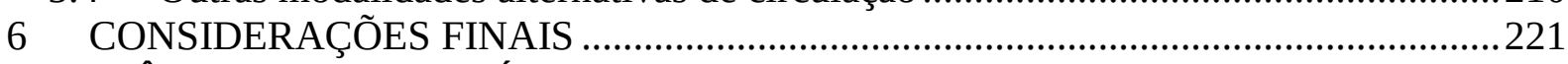

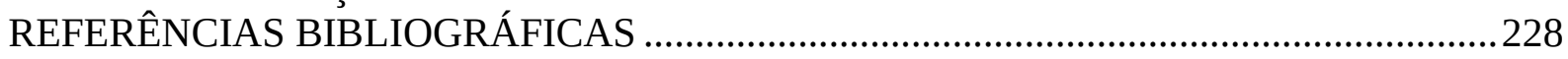

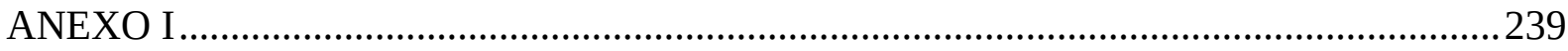

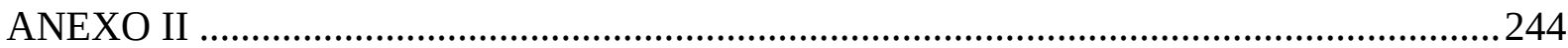

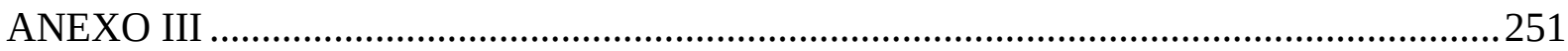

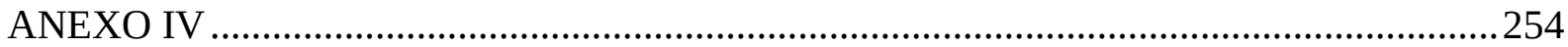




\section{LISTA DE ILUSTRAÇÕES}

Figura 1 - Capa e contracapa de O Gato de Botas, Coleção Contos Abril (1947)

Figura 2 - Página interna e contraguarda da contracapa de O Gato de Botas, Coleção Contos Abril (1947)

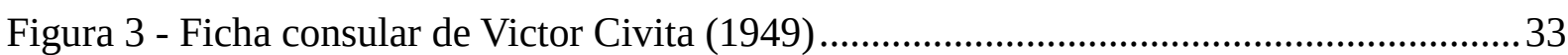

Figura 4 - Anúncio do lançamento de Pato Donald (1950) …..................................................37

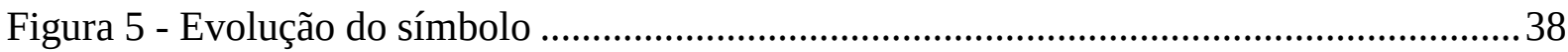

Figura 6 - Primeira sede da S.A.I.B., na Rua Nova dos Portugueses ..................................... 40

Figura 7 - A Bíblia Mais Bela do Mundo, encadernada............................................................. 46

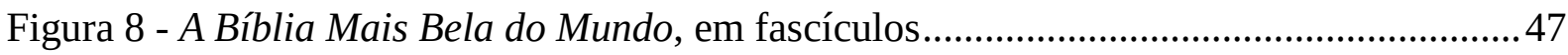

Figura 9 - Peça de divulgação da Coleção Era uma Vez... (1967).............................................. 51

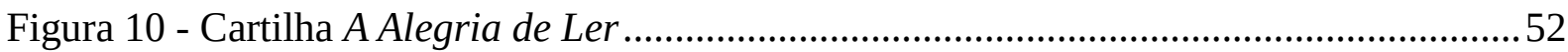

Figura 11 - Primeiros livros individuais, ainda em formato de revista, lançados pela Editora

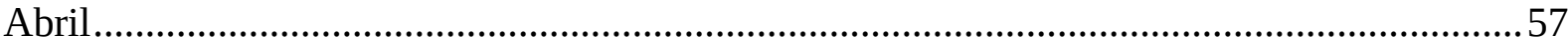

Figura 12 - Estante projetada pela Mobília Contemporânea para as coleções da Abril Cultural

Figura 13 - Estante projetada pela Mobília Contemporânea para as coleções da Abril Cultural

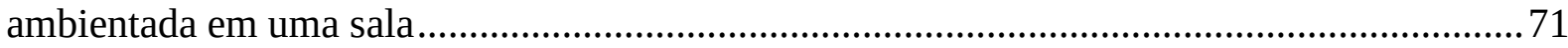

Figura 14 - Padrão de capa e lombada dos exemplares da Coleção ......................................... 82

Figura 15 - Cabeceado padrão utilizado em todos os exemplares da Coleção.......................... 83

Figura 16 - Ficha com o registro do nro. de inspeção para garantia da encadernação .............. 83

Figura 17 - Folha de rosto padrão nos exemplares da Coleção ................................................. 84

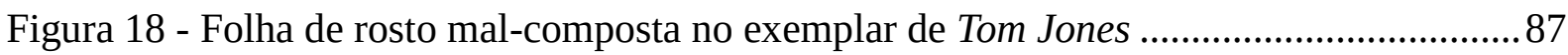

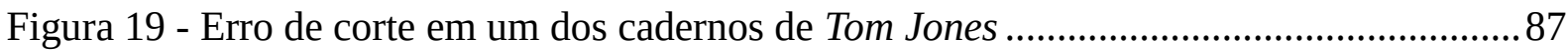

Figura 20 - Página de Tom Jones com diagramação correta .................................................. 87

Figura 21 - Comparação entre um fragmento do miolo de Tom Jones (acima) e As Relações

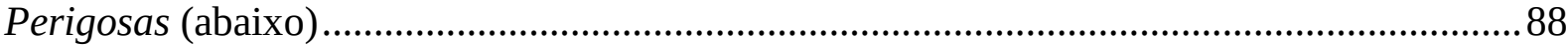

Figura 22 - Diferença de papéis utilizados em um mesmo volume, identificáveis pelo nível de

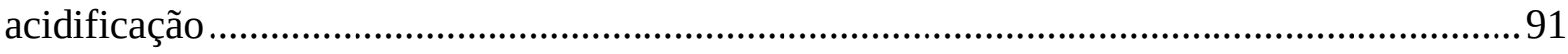

Figura 23 - Diferença de nível de acidificação entre páginas de um mesmo volume ..............92

Figura 24 - Capa e lombada marrom da Coleção Os Imortais da Literatura Universal ........... 93

Figura 25 - Folhas de guarda dos exemplares de capa marrom..............................................93

Figura 26 - Lombada de livro formado pela encadernação das capas “descartáveis” dos fascículos de Os Imortais da Literatura Universal ............................................................95

Figura 27 - Fascículos encadernados e refilados, com a paginação no limite do corte............96

Figura 28 - Interior de um fascículo sobre Gabrielle Colette, ilustrado com um nu de

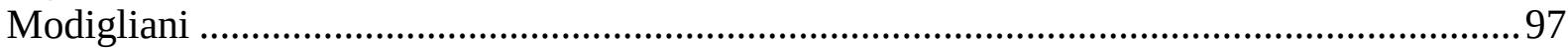

Figura 29 - Contracapa do Fascículo dedicado à Turguêniev, com propaganda do próximo exemplar, Retrato do Artista quando Jovem, de James Joyce....................................................98

Figura 30 - Capa e lombada de um volume da coleção Os Pensadores ..................................106

Figura 31 - Falsa folha de rosto e folha de rosto em Os Pensadores ....................................107

Figura 32 - Detalhe da primeira contracapa do volume dedicado a Pascal, onde se lê "cola". 
Figura 33 - Indicação de patrocínio de Teatro Vivo na abertura e entre os intervalos comerciais do espetáculo O Gesto, A Festa, A Mensagem: 2000 Anos de Teatro ....................................117

Figura 34 - Lombada e capa padrão de um exemplar de Teatro Vivo....................................121

Figura 35 - Folhas de rosto de Estado de Sítio e Marat-Sade ...............................................124

Figura 36 - Peça de lançamento de Máquinas e Metais - 1964 ...............................................154

Figura 37 - Peça televisiva para divulgação da coleção História do Século XX .....................159

Figura 38 - Interior de panfleto de divulgação da coleção Os Imortais da Literatura Universal

Figura 39 - Panfletos de divulgação da coleção Os Imortais da Literatura Universal ...........166

Figura 40 - Propaganda veiculada na Revista Realidade ................................................166

Figura 41 - Panfleto de divulgação da coleção Os Imortais da Literatura Universal.............167

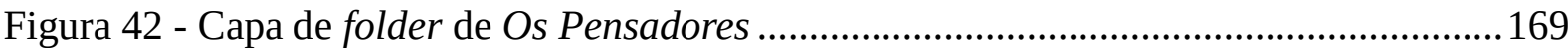

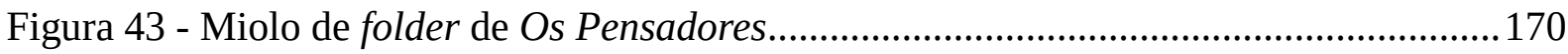

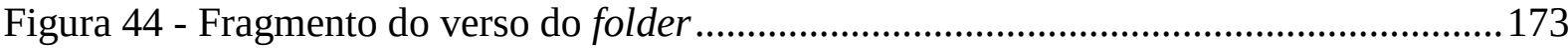

Figura 45 - Panfleto de incentivo à manutenção da coleção ...............................................175

Figura 46 - Folder para promoção da venda por marketing direto ..........................................176

Figura 47 - Peça promocional de Teatro Vivo em duas páginas de Veja ................................178

Figura 48 - Propaganda da coleção de fascículos Nossas Crianças.......................................179

Figura 49 - Folder de divulgação da coleção A Grande Aventura do Homem para jornaleiros

Figura 50 - Propaganda comemorativa “Abril 25 anos” ..................................................... 183

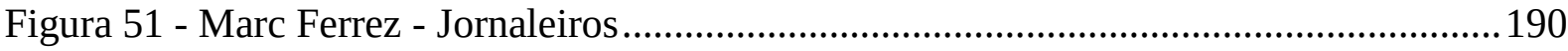

Figura 52 - Hildegard Rosenthal - Menino Jornaleiro (São Paulo/SP) (1939)........................ 190

Figura 53 - Vendedor de Pão Doce - Marc Ferrez - Rio de Janeiro (RJ) c. 1895.................... 192

Figura 54 - Banca de jornal no centro de São Paulo (SP) - Alice Brill (c. 1953) ................... 193

Figura 55 - Capas de exemplares da Coleção Avec ............................................................... 196

Figura 56 - Capas de exemplares da "Edições Segredo”...........................................................197

Figura 57 - Banca de jornais na Praça da Sé (SP) com produtos expostos - Domingos de Miranda Ribeiro - 1966

Figura 58 - Fragmento de peça publicitária voltada a jornaleiros onde se salienta a importância da exposição adequada dos exemplares

Figura 59 - Brindes oferecidos junto à coleção A Grande Aventura do Homem encaminhados

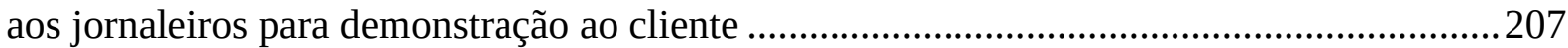

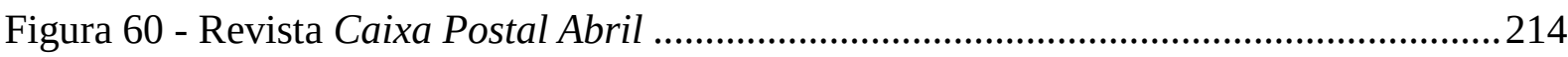

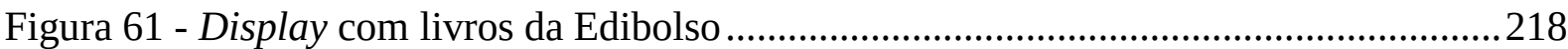

Figura 62 - Sistema de produção dos livros colecionáveis da Editora Abril .........................222 


\section{INTRODUÇÃO}

A publicação de livros pela Abril Cultural, divisão da Editora Abril, foi um fenômeno marcante no mercado editorial da década de 1970, tanto pela relevância e qualidade dos projetos quanto pelo alcance geográfico e social que as edições obtiveram. Em forma de coleções, algumas delas acompanhadas de fascículos, a venda de volumes em tamanho convencional (por vezes de grande formato), em capa dura e acabamento primoroso, ainda é um caso surpreendente, dadas as condições do setor editorial brasileiro naquele período. Os exemplares publicados ainda hoje podem ser encontrados em estantes de bibliotecas particulares, públicas e universitárias e são obtidos com certa facilidade em lojas de livros usados, permanecendo como referências em bibliografias de cursos de graduação e pósgraduação no Brasil.

A partir destas características, junto ao interesse do autor por edições populares, estabeleceu-se a pergunta que deu origem a esta pesquisa: como foi possível realizar, em um país com um público pouco familiarizado com livros encadernados de bom acabamento e luxuosa ornamentação, precária estrutura produtiva para impressão de livros, um setor editorial com baixa tiragem média ${ }^{1} \mathrm{e}$ uma população com reduzidos índices de leitura, um projeto editorial tão singular, que atravessou gerações e ainda hoje, em certos aspectos, nunca mais foi repetido, ao menos nas mesmas dimensões e no mesmo alcance?

Propusemo-nos, como forma de compreender a questão, investigar a produção, a circulação e a apropriação dos livros publicados pela Abril Cultural na década de 1970, período em que se consolida, conforme Ortiz (2006), o mercado de bens culturais no Brasil. O enfoque será nas três coleções de livros mais importantes da Editora: Os Imortais da Literatura Universal, de 1970; Os Pensadores, de 1972; e Teatro Vivo, de 1976. Comercializados em bancas de jornais, pontos alternativos ao espaço institucionalizado das livrarias e melhor distribuídos geograficamente, os livros da Editora Abril alcançaram o grande público ao disponibilizarem textos considerados de "alta cultura", sob a perspectiva apontada por Umberto Eco (2006).

${ }^{1}$ Conforme Vieira (1975), em meados da década de 1970, a tiragem média de um livro técnico nunca era inferior a 10.000 exemplares nos EUA, enquanto, no Brasil, poucas vezes era superior a 5.000 , sendo frequentes tiragens de 3.000 exemplares. 
Tal perspectiva se refere à divisão original proposta por Dwight MacDonald, em 1962, de produtos canonizados pela crítica e que, até então, eram reservados ao limitado público das elites sociais e culturais.

O recorte temporal proposto para os objetivos deste trabalho, os anos 1970, é caracterizado pelas importantes transformações que ocorrem nos âmbitos econômico, político e social e que têm grande influência sobre a demanda e produção não apenas de bens de consumo, mas, também, de bens culturais e simbólicos. Ainda que limitados, houve avanços nas estatísticas de escolarização e renda durante o período, e a industrialização crescente aumentou a oferta de vagas aos poucos profissionais qualificados, elevando os vencimentos do proletário superior. Junto à evolução da renda do trabalhador especializado, surge, nesse período, o que Singer (1981, p. 173-185) denominou "a 'nova' classe média", composta por funcionários assalariados de alta renda que incluem "[...] técnicos, gerentes, assistentes etc. [...]". Eles, em consequência, beneficiaram autônomos e profissionais liberais, que passaram a contar com uma clientela melhor remunerada, sendo esses últimos, inclusive, favorecidos pelo incremento de vagas no ensino superior.

Embora houvesse considerável melhoria da situação econômica nacional, o desenvolvimento não seguiu o padrão apresentado por países centrais, o que leva Ortiz (2006, p. 45) a considerar, devido a isso, que "em termos culturais [...] o processo de mercantilização da cultura será atenuado [e] a 'indústria cultural' e a cultura popular de massa emergente se caracterizam mais pela sua incipiência que pela sua amplitude". A Abril procurou romper com essa condição limitante ao buscar, por si, meios para o desenvolvimento da indústria cultural no país, ao menos no campo da edição de livros e periódicos. Para isso, baseada na grande empresa de comunicação que foi, utilizou-se de sua estrutura editorial, publicitária e distributiva como mecanismo propulsor do extraordinário volume de vendas de obras de cunho erudito (literatura clássica, filosofia e teatro) que conseguiu obter através de bancas de jornais.

Estabelecemos, de maneira que se pudesse adequadamente realizar o estudo, as seguintes estruturas investigativas: 1) as condições histórico-sociais que permitiram o crescimento de uma pequena editora, fundada por estrangeiros em São Paulo, capital, no final dos anos $1940 ; 2$ ) as características materiais e textuais das 
publicações e sua intrínseca relação condicionante do perfil de público a que eram destinadas; 3) o papel da máquina publicitária da Editora Abril e a competente capacidade de concepção e difusão de discursos promocionais, com eficaz teor persuasivo em relação a segmentos específicos de consumidores; 4) as estratégias de distribuição editorial através das bancas de jornais e outros canais de vendas distintos do legitimado espaço das livrarias. Nosso objetivo é, através da hipótese inicial de investigação, demonstrar como esses aspectos se coadunaram de maneira a possibilitar que o fenômeno da venda de livros ditos de "alta cultura" se realizasse, tendo em perspectiva as condições restritivas ao desenvolvimento do mercado que, a princípio, pareciam impedir o avanço da indústria de bens culturais em termos de livros produzidos em uma cultura de massa.

\subsection{As ideias iniciais}

Para compreendermos a importância da divisão Abril Cultural dentro da enorme estrutura econômica e comunicacional da Editora Abril S. A., precisamos considerar alguns pontos de partida, referências básicas para a compreensão de fatos e conceitos que se apresentaram durante o decorrer do estudo. Embora tenha sido um dos principais agentes para o desenvolvimento do mercado editorial brasileiro, não há volume considerável de pesquisas realizadas sobre edições colecionáveis vendidas em canais alternativos de distribuição ${ }^{2}$. No que se refere a estudos sobre a Editora Abril, destacam-se os trabalhos de Mira (1997), que busca compreender o público e o mercado das revistas da Editora a partir da segmentação dos periódicos e seus consumidores, e de Pereira (2009), que investiga o enciclopédico Almanaque Abril, sob a ótica da historiografia e da relação de jornalistas e historiadores com a escrita da História.

No que concerne ao panorama histórico, ressalta-se que, até a década de 1940, o país ainda era industrialmente pouco desenvolvido, situação que só começaria a se alterar a partir dos anos 1950/1960 (SINGER, 1981; FAUSTO, 2001).

2 Considera-se como canal institucionalizado, neste projeto, as livrarias e suas redes, concentradas nas regiões Sul e Sudeste do país e em áreas centrais das cidades, sendo, portanto, pouco utilizadas como equipamento para acesso ao livro e à leitura por habitantes de regiões periféricas. 
Acompanhando o ritmo do país, entre 1930 e 1950 o mercado editorial brasileiro não apresentou crescimento (em 1953 o número de editoras havia regredido a um patamar menor que o de 1936), devido a obstáculos como a tributação do papel (havia subsídios apenas para papel de imprensa) e do livro, que, somados à taxa do dólar, tornavam mais vantajosa a importação que a produção nacional (ORTIZ, 2006).

Apesar das edições apresentarem declínio, o desenvolvimento observado no país após a Segunda Guerra Mundial, junto às políticas de incentivo à alfabetização e à leitura a partir da década de 1960, foram responsáveis pela constituição de um novo público consumidor de livros, mais amplo e menos elitizado, formado pela classe média em ascensão e por profissionais do terceiro setor dos grandes centros urbanos. Nesse contexto, identifica-se, conforme Pignatari (2008), o surgimento no Brasil de uma publicidade mais elaborada, com o intuito de idealizar uma forma de linguagem que outorgasse status e legitimidade a essa classe social em formação.

A comunicação publicitária é instrumento fundamental para o desenvolvimento da indústria cultural, por introduzir significados através de sua linguagem e legitimar produtos e bens culturais. A Editora Abril investiu amplamente na divulgação de suas coleções de livros entre os mais diversos meios, desde suas próprias publicações até periódicos de grande circulação, além de peças radiofônicas, comerciais televisivos, anúncios em outdoors e nas próprias bancas de jornais. Seu discurso publicitário é característico de um novo modelo de circulação de bens simbólicos, alinhado aos padrões de conspicuidade identificados desde o final do século XIX e elencados pelas teorias sociológicas e antropológicas do consumo (VEBLEN, 1983; BAUDRILLARD, 2010; BORDIEU, 2011).

O crescimento do contingente de consumidores, a evolução e serialização dos métodos produtivos e o desenvolvimento dos meios de comunicação, elevando a influência do discurso disseminado pelas propagandas, permitiram a solidificação no país do mercado de massas e fizeram surgir aqui uma indústria cultural, conceito estudado por teóricos da Escola de Frankfurt (ADORNO; HORKHEIMER, 1985; MARCUSE, 1979; BENJAMIN, 2012). Ainda que incipiente, ela se tornaria modelo para a produção de bens culturais a partir de meados do século XX no Brasil.

A produção cultural e de bens simbólicos voltada às massas tem como base a questão do valor de venda e da distribuição. As coleções Abril Cultural, ao difundirem, através da eficiente conjunção destes dois fatores, livros antes restritos a 
um circuito muito específico da população, ampliam o acesso a esses produtos, embora sua apropriação dependa de instrumentos, sobretudo educacionais, que a maior parte do novo público não possui. O apoio para reduzir a deficiência na apropriação dos livros de autores considerados eruditos nas áreas da literatura e ciências humanas se efetiva pelo bom nível das traduções e pela presença de introduções e biografias através dos fascículos, que procuraram familiarizar o leitor em relação ao escritor, o panorama histórico em que viveu e a relação do autor e sua obra com escolas artísticas em que se insere. Essa mediação, claro, limita-se pela própria diferença na formação de indivíduos pertencentes a distintas posições sociais, já que as classes médias não são homogêneas; mas é um elemento, ao menos, de estímulo à incursão em textos incomuns à maioria da literatura de massas, leve e ligeira.

Umberto Eco (2006) discute o consumo cultural entre as massas proporcionado pela indústria cultural, distinguindo apocalípticos, que pretendiam classificá-la como alienante, e integrados, que nela viam a oportunidade de uma circulação menos restrita dos bens culturais. Suas considerações contribuem para a compreensão de como ocorre a recepção de obras do cânone entre os segmentos de leitores de livros populares.

Em relação à formação de um novo público para livros colecionáveis e de caráter erudito, a mediação cultural em seu nível funcional, conforme Davallon (2007), tem por objetivo proporcionar ao público o acesso a "obras (ou saberes) e a sua ação consiste em construir uma interface entre esses dois universos estranhos um ao outro (o do público e o, digamos, do objeto cultural) com o fim precisamente de permitir uma apropriação do segundo pelo primeiro". Mediação que se constrói, nesse sentido, pela fruição de informação e conhecimento entre grupos distintos a partir da intervenção de um terceiro agente, o mediador cultural.

Ainda, as edições de livros da Abril assumem papel relevante para a documentação do estágio de transformações pelas quais passava o setor editorial do país durante o período. Conforme Le Goff (1990, p. 545-553), “o documento não é qualquer coisa que fica por conta do passado, é um produto da sociedade que o fabricou [...]" e "[...] os vestígios da cultura material, os objetos coleção[...]" devem ser considerados como documentos legítimos para a interpretação histórica. O livro, portanto, visto também como produto da cultura material, como objeto de coleção, como forma, incumbe-se de função que ultrapassa os limites do texto nele 
registrado, redimensionando a perspectiva da informação que suporta, tornando-se, em si, fonte relevante para a pesquisa dos processos de produção, circulação e apropriação bibliográfica.

A produção e distribuição de livros, fascículos e periódicos em bancas de jornais, no que tange à cultura material e à apropriação social da informação, não contam com grande volume de estudos. A ausência de um maior número de fontes bibliográficas interpretativas, principalmente no campo da cultura material do livro no Brasil, impõe o desafio de um estudo sem diversidade de referenciais, que demanda maior volume e acuidade na investigação de documentos e fontes primárias como forma de obtenção de dados, bem como a opção pelo método de análise material para que se possa recuperar informações que permitam a adequada investigação do objeto de pesquisa.

\subsection{A estrutura}

Além da introdução e das considerações finais, o trabalho está dividido em quatro capítulos que tratam da fundação e ascensão da empresa; produção e materialidade dos livros; mecanismo e meios de divulgação e dinâmica de circulação das coleções editadas pela Abril durante a década de 1970. Optamos por não segmentá-los excessivamente, permitindo que se construísse um fluxo que percorre a linha temática e estabelece uma unidade ao conjunto, apesar das divisões para fins didáticos. Dessa maneira, o fenômeno do bom volume de vendas que as edições apresentaram são reflexo de um processo contínuo que tem origem no estabelecimento da estrutura empresarial e comunicacional da editora. Tal processo tornou possível a produção de exemplares muito bem-acabados, acima do padrão para o mercado editorial do período, cuja materialidade responde aos anseios de um determinado público-alvo atingido pela massiva propaganda feita pela máquina de divulgação da Abril. A esse público, o eficiente sistema de distribuição da empresa permitiu encontrar com facilidade os livros em todo o país.

Da mesma forma, determinados conceitos são trabalhados ao longo de mais de um capítulo, assim como os panoramas histórico, econômico, social e editorial brasileiro são apresentados conforme se avança nas análises das coleções, 
permitindo uma perspectiva de cada lançamento de acordo o cenário no momento de sua publicação. Pretendemos, com isso, demonstrar que as condições estruturais, materiais, publicitárias (discursivas) e distributivas não eram independentes, e se conjugaram para que o extraordinário nível de vendas se realizasse.

Para iniciar o estudo, abordaremos, no capítulo 2, o percurso histórico da Editora Abril no Brasil, fundada por César Civita no final dos anos 1940 como uma espécie de subsidiária da Editorial Abril, estabelecida desde 1941 em Buenos Aires, Argentina. Acompanharemos os esforços iniciais de Victor Civita para ampliar a empresa, que se ramificou em editora, gráfica e distribuidora, apesar das dificuldades enfrentadas decorrentes da precária infraestrutura nacional na década de 1950. Erigido o conglomerado que se tornou a Abril, é criada a divisão Abril Cultural, responsável pela edição dos fascículos e primeiros produtos culturais, que, a partir de 1970, publicará também livros.

Identificado o alicerce responsável por viabilizar o lançamento das coleções, concentraremos, no capítulo 3 , as análises das características formais dos exemplares, embora também dediquemos espaço às questões textuais, como a tradução. O que propomos é olhar para o livro não apenas como produto editorial, mas também como resultado material do processo de edição, permitindo dar "voz" ao que suas páginas, capas, formatos, mancha tipográfica, seu tipo, sua caixa e peso, diagramação e marcas do tempo, "dizem-nos" como elementos que revelam dados sobre seu processo produtivo, o público a quem se destina e canais em que é comercializado, informações que, muitas vezes, não são evidenciadas por outras fontes e métodos de pesquisa. Em uma ótica quase detetivesca, quais pistas, escondidas na forma do livro, podem ser descobertas a partir um olhar mais atento? Neste capítulo, tratamos, ainda, de questões econômicas e sociais do período e, com um enfoque mais subjetivo, do colecionismo bibliográfico, sob o ponto de vista psicológico e social, investigando de que maneira ele age como força motriz do processo de estímulo à compra dos muitos volumes das coleções editadas pela Abril Cultural.

Dando sequência à dinâmica das coleções, segue-se, no capítulo 4, o componente que chamamos de "adubo", que fez a "árvore", símbolo da Abril, 
crescer. A metáfora mostra-se adequada quando observamos a propaganda funcionando como um agente catalisador da comercialização dos exemplares e convencimento à manutenção de compra ao longo da coleção. Para Darnton,

\footnotetext{
"toda a questão da propaganda do livro requer exame. Muito se aprenderia sobre as atitudes em relação aos livros e o contexto de sua utilização estudando a maneira como eram apresentados - a estratégia do apelo, os valores invocados pelo discurso empregado - em todos os tipos de publicidade [...]" (DARNTON, 2010, p. 141).
}

Procuraremos compreender algumas questões sociais e do imaginário coletivo que condicionaram a produção das propagandas produzidas para a divulgação dos lançamentos da Editora. A comercialização de mercadorias era também a de símbolos; e as análises de peças publicitárias veiculadas pela Abril são instrumentos valiosos para o reconhecimento do público-alvo, identificado na época através de pesquisas de público às quais, infelizmente, o Departamento de Documentação (DEDOC) da Editora nos negou acesso. Procuramos contornar essa restrição construindo a "figura" do consumidor ideal das três coleções através das avaliações pospostas.

Por fim, o capítulo 5 busca determinar o processo de distribuição e comercialização dos exemplares, com ênfase na venda em bancas de jornais, principal canal pelo qual circularam os livros das coleções da Abril Cultural, mas também identificando outras formas de distribuição alternativas às livrarias, utilizadas pela Abril e outras editoras, e que atenderam ao mercado de massa na década de 1970. Por ser a circulação um dos entraves ao crescimento do setor editorial brasileiro, devido ao limitado contingente de livrarias funcionando no país, o estudo da estrutura e métodos distributivos da Abril é relevante para compreendermos as possibilidades de ampliação do acesso ao livro e melhora na tiragem média das edições e barateamento dos exemplares.

\subsection{Métodos e procedimentos}

A pesquisa que apresentamos é de cunho teórico, desenvolvida através de levantamento bibliográfico e documental. Inicialmente, contávamos com alguns 
documentos que, devido a citações em outros trabalhos, sabíamos que estariam disponíveis no Departamento de Documentação da Editora Abril (DEDOC). Infelizmente, apesar de a Editora admitir a existência e armazenamento de tais documentos em boas condições, não tivemos autorização e justificativa do veto a determinados documentos arquivados pela empresa, ainda que tenhamos formalizado o pedido através de carta institucional entregue à responsável pelo setor. A partir deste limitante, foi necessário reestruturar o trabalho para contornar a ausência dessa documentação, essencial especialmente quanto: 1) ao estudo dos processos editoriais (aos quais bonecos, exemplares originais, modelos de edição, planos editoriais e comunicação interna seriam fundamentais) e 2) circulação e público-alvo das coleções, através de pesquisas de público, estatísticas de vendas, dados de comercialização regional dos exemplares e segmentação do mercado, entre outros).

Como nos foram disponibilizados apenas os clippings, digitais e em papel, que o Departamento produziu ao longo dos anos, com peças publicitárias; reportagens (algumas de cunho negativo) em periódicos e discursos dos proprietários da Abril em eventos; além de listagem de exemplares, que, por ter sido feita com os livros da biblioteca da instituição, apresentava falhas, optamos por dar ênfase à questão analítica-investigativa desse material e com ele procurar atingir resultados próximos ao que almejávamos inicialmente.

Contamos, ainda, com a documentação do Arquivo Público do Estado de São Paulo, que muito gentilmente nos atendeu e auxiliou; o acervo digital de periódicos da Hemeroteca Digital da Biblioteca Nacional, de substancial valor para a obtenção de dados históricos da pesquisa; o Acervo Digital da Revista Veja, que permitiu compreender como o principal produto editorial da Abril propagandeava as coleções, além de fornecer, em muitas reportagens, elementos relevantes para a investigação dos processos de edição; os acervos de grandes jornais como O Estado de São Paulo (SP), Folha de São Paulo (SP) e O Globo (RJ); o CPDOC-FGV, Centro de Pesquisa e Documentação de História Contemporânea do Brasil, da fundação Getúlio Vargas; entre outros repositórios pontualmente utilizados, que são indicados nas referências e notas do trabalho.

A bibliografia foi em parte obtida nas Bibliotecas da Escola de Comunicação e Artes (ECA) e da Faculdade de Filosofia, Letras e Ciências Humanas (FFLCH), ambas da Universidade de São Paulo, campus Butantã, que se complementou com 
o acervo pessoal do autor no campo de história do livro e história editorial brasileira. Não se pode esquecer de "centros de documentação" pouco lembrados e valorizados no meio acadêmico, mas aos quais aqui prestamos nossa homenagem: as livrarias de livros usados, sebos, alfarrábios. Nestes espaços não institucionalizados de pesquisa, obtivemos os volumes que são avaliados no capítulo 3, assim como identificamos exemplares ainda com o invólucro original de quando foram vendidos, há mais de quatro décadas, que nos permitiram compreender de que maneira eram comercializados. No interior de alguns volumes, encontramos fichas do Departamento de Capas e Volumes para possíveis reclamações sobre a encadernação, assim como diversas peças publicitárias e panfletos de identificação dos títulos seguintes da coleção. Através das marcas do tempo, que acidificam mais determinados pontos que outros, pudemos reconhecer contingências sobre a utilização do papel para impressão dos livros.

Optamos pelo recorte temporal que abrangesse o período de maior relevância das publicações bibliográficas da Abril Cultural, a década de 1970, embora suas atividades tenham sido estabelecidas em 1966 e encerradas em 1982. A partir de 1970, iniciam-se as publicações pela Editora de livros completos encadernados (anteriormente eram comercializados apenas os fascículos individuais), dentre os quais um dos primeiros projetos foi o lançamento da coleção Os Imortais da Literatura Universal, dedicada a publicar, em capa dura e com texto integral, romances, contos e novelas clássicos e modernos, de valor literário reconhecido pela crítica. Seguem-se outras edições de livros, mas os destaques recaem em Os Pensadores, de 1972, e Teatro Vivo, de 1976, voltadas, respectivamente, a coleções de autores do cânone em filosofia e teatro, ambas em capa dura, sendo Os Pensadores de tamanho maior que as demais. A essas três coleções daremos maior destaque durante o estudo por terem sido inovadoras quando lançadas e, ainda hoje, representarem projetos editoriais célebres por sua qualidade no estabelecimento dos textos, paratextos (estudos introdutórios, notas, índices) e tradução, além da excelente impressão e acabamento, o que os torna referência em boa parte dos currículos dos cursos universitários de ciências humanas atuais.

Ao final dos anos 1970, conforme Hallewell (2005), a concorrência com outras editoras e a dedicação a outros projetos fez com que as edições de livros pela Abril tivessem sua importância reduzida; tal fato, somado aos altos índices de inflação, que requeriam constante reajuste de preço dos exemplares, estimulou a diminuição 
do investimento nessa modalidade editorial. A cisão da empresa em 1982, após a desavença entre os irmãos Roberto e Richard Civita finalizou, de maneira infeliz, a história da Abril Cultural.

A escolha do repertório pautou-se pela busca por fontes e testemunhos em periódicos publicados durante a década de 1970, de maneira que se pudesse caracterizar, resguardadas as limitações, o Zeitgeist, o clima, o espírito do tempo daqueles anos. Para esse objetivo, muito contribuiu a entrevista de Fernando Nuno, preparador de texto de Os Imortais da Literatura Universal e outras coleções, embora em contato tardio devido à dificuldade em identificar profissionais que trabalharam nas coleções ${ }^{3}$ ainda vivos e dispostos a contribuir para o trabalho.

O segundo capítulo foi elaborado fundamentalmente através de pesquisas historiográficas e documentais, enquanto o terceiro valorizou as análises materiais de alguns volumes de cada uma das coleções, feitas sob a ótica da bibliografia material e da bibliografia analítica (MCKENZIE, 1999; GASKELL, 2000; DARNTON, 2010). Ambas contribuem para a reconstituição dos processos produtivos e espaços de circulação dos livros editados pela Abril Cultural, permitindo perceber, conforme Darnton (MCKENZIE, 1999; GASKELL, 2000; DARNTON, 2010, p. 141), “como os leitores entendem os sinais da página impressa[...]". Nesse sentido, a sociologia dos textos, proposta por McKenzie (MCKENZIE, 1999; GASKELL, 2000; DARNTON, 2010), possibilita a interpretação das circunstâncias em que os textos afetam e são afetados pelas sociedades ao longo do tempo. Para isso, procuramos selecionar como amostra três exemplares, publicados um no começo, um no meio e um no fim da coleção, de forma que fosse possível identificar o desenvolvimento do processo produtivo e características particulares de acordo com o período de publicação, uma vez que as coleções demoravam cerca de dois anos para serem concluídas.

Embora duas das coleções analisadas viessem acompanhadas de fascículos à parte, colecionáveis para a formação de outros volumes a serem encadernados, o foco das avaliações foi apenas no livro, com exceção de Teatro Vivo, em que os fascículos são inseridos nos volumes, como elementos introdutórios, em papel

3 A maioria dos fascículos creditava apenas uma pequena parte dos responsáveis por sua elaboração, dificultando o trabalho de se encontrar profissionais que trabalharam na Editora. 
diferente do texto das obras. A aferição das margens foi feita pela medição de amostras de três páginas do início, três do meio e outras três da parte final do exemplar, sempre em mais de um caderno por segmento, de maneira com que se pudesse identificar desconformidades na marginação relacionadas a defeitos nos cortes (refile) no papel, impressão ou encadernação. Para assegurar que possíveis variações não estivessem relacionadas a desproporções da mancha tipográfica, realizou-se também a aferição de seu tamanho, em 5 páginas de diferentes cadernos e regiões do livro (início, meio e fim).

O capítulo 4 foi elaborado através de um estudo teórico, feito por levantamento bibliográfico, de termos e conceitos referentes à "cultura de massa", níveis culturais ("alta", "média" e "baixa" cultura) e indústria cultural, além da relação entre propaganda e identidade; tal relação nos permitiu compreender, junto a elementos da Análise do Discurso, o contexto e o sentido dos discursos publicitários desenvolvidos para a divulgação das coleções. Por esse recurso, concebeu-se o público a quem o discurso se dirigia, permitindo a construção do perfil do consumidor preferencial para cada uma das edições.

Para identificar questões técnicas da propaganda, optamos pelos conceitos definidos por Fernando Almada (1975), publicitário de destaque nos anos 1970, presentes em um capítulo de obra publicada no período (1975), que identifica estratégias e argumentos de marketing e motivações dos consumidores de livros, através dos quais seria possível aumentar o nível de vendas no mercado editorial.

O processo de distribuição e o estudo dos canais alternativos de vendas de livros, abordados no capítulo 5 , foram produzidos através de revisão bibliográfica, embora haja pouco material publicado sobre a circulação de livros para o público de massa; e, principalmente, pela pesquisa em fontes da época, como jornais e revistas, procurando identificar artigos, propagandas, críticas literárias, cartõesresposta e quaisquer outros elementos que permitissem reconstituir a maneira como eram distribuídos os livros em canais alternativos na década de 1970. Procuramos dar destaque às bancas de jornais, por serem o sistema em que circularam as coleções que são objeto de nosso estudo, mas procuramos, também, oferecer um panorama dos diversos canais alternativos, com ênfase naqueles utilizados pela Abril em seus produtos culturais. 
Realizados os preâmbulos e identificados os métodos, seguimos para a São Paulo dos anos 1940, cidade em intensa industrialização, na qual um italiano, de nome Cesare Civita, chega em 1945 para verificar se o país vizinho ao de sua promissora casa editorial tinha a potencialidade que imaginava para implantar uma filial de sua Editorial Abril. 
Da América do Sul Você precisa

E o rio de asfalto e gente entorna pelas ladeiras entope o meio fio

Clube da Esquina ํㅡ 2 (Milton Nascimento, Lô Borges e Márcio Borges)

\section{A HISTÓRIA DE UM MILANÊS NOVAIORQUINO NO PAÍS ONDE NINGUÉM LÊ: A CONSTITUIÇÃO DA EDITORA ABRIL}

No final dos anos 1940, São Paulo era uma cidade transformada e em transformação. Transformada pelo deslocamento do centro de produção e comércio de café da capital federal, Rio de Janeiro, para o então provinciano Estado de São Paulo, desde meados do século anterior, o que modificou profundamente a sua capital devido à confluência da riqueza gerada pelo ouro negro. E em transformação após sucessivos contratempos: primeiro, a crise mundial de 1929, que pôs fim ao ciclo econômico do café; depois, a tentativa fracassada de revolução, no ano seguinte, e as dificuldades enfrentadas pelo país com o início da Segunda Guerra Mundial, em 1939.

Os cenários de bonança e de vicissitude conjugam-se e constituem, econômica e socialmente, a cidade na primeira metade do século XX. A bonança sobreveio por décadas com o período cafeeiro. Região privilegiada por suas terras férteis e vastas áreas disponíveis para o plantio, o Oeste Paulista e o Vale do Paraíba ganharam destaque na produção de café a partir da segunda metade do século XIX. Antes do advento da cafeicultura, São Paulo era uma cidade acanhada, 
com feições coloniais e restrita a um povoado incrustado entre os vales do Anhangabaú e Tamanduateí ${ }^{4}$.

O capital oriundo da produção e do comércio do café, acumulado ao longo dos anos de bonança, permitiu o investimento dos capitalistas do café em novos setores e foi responsável pelo importante desenvolvimento da cidade nas primeiras décadas do século $\mathrm{XX}$, conjugando-se com o processo de industrialização iniciado no final do século anterior. A partir dele, São Paulo se transformaria da antiga província ao maior parque industrial do hemisfério Sul. Em pouco menos de 40 anos, diversas obras infraestruturais foram executadas. Entre elas, vias foram alargadas, dando espaço ao intenso fluxo automotor ${ }^{5}$ e os rios, então predominantes na paisagem urbana, foram canalizados e retificados. Findava-se a antiga cidade do começo do século, com seus sinuosos canais fluviais e ruas estreitas, e surgia a grande metrópole, reconhecida por Fiorello La Guardia, em visita à cidade ${ }^{6}$, como a "Nova York da América do Sul”, que já em $1940^{7}$ era a segunda mais populosa cidade do país (A ESTADA..., 1946, p. 4).

São Paulo foi industrializada também pela atividade de imigrantes italianos, japoneses, espanhóis, alemães, entre outras nacionalidades que compunham 35\% de seus habitantes em $1920^{8}$. A partir da crise de 1929, o processo de industrialização da capital acentua-se, deslocando-se da dependência do capital cafeeiro e da produção de bens de consumo não-duráveis (CANO, 1975) para diversificação de recursos e a produção de bens duráveis. A Segunda Guerra Mundial teve papel fundamental no surgimento de indústrias para atender à demanda interna crescente. A política de substituição de importações fora

4 Para melhor caracterização da cidade no século XIX, recomenda-se os trabalhos de Odilon Nogueira de Matos ("A cidade de São Paulo no século XIX"), de 1955, e o compêndio "História da Cidade de São Paulo", vol. 1, de Paula Porta (Org.), publicado em 2004.

5 Para mais detalhes sobre o plano de avenidas implantado pelo prefeito Francisco Prestes Maia na década de 1930, ver MAIA, Prestes. Estudo de um Plano de Avenidas para a cidade de São Paulo. São Paulo: Melhoramentos, 1930.

6 Fiorello La Guardia foi prefeito da cidade de Nova York entre 1934 e 1945 e esteve no país em fevereiro de 1946 como embaixador especial do governo americano para a solenidade da posse do presidente Eurico Gaspar Dutra.

7 IBGE. Censo demográfico de 1920.

8 lbid. 
implementada pelo governo de Getúlio Vargas já no final de 1937, conforme Fausto (2001), mas teve sua escala ampliada após o início do conflito.

Na década de 1940, a cidade já apresentava um desenvolvido e diversificado parque industrial, que sobrepujava economicamente a capital federal, embora o centro político, artístico e cultural permanecesse no Rio de Janeiro. No final de junho de 1945, Cesar Civita chegou a São Paulo com 400 pesos argentinos e um visto para 60 dias de permanência no país. Havia fundado, quatro anos antes, sua editora na Argentina e possuía a licença para edição dos personagens de Walt Disney na América Latina. Por lá, publicou revistas femininas (Claudia), fotonovelas (Idilio), quadrinhos infantis (El Pato Donald) e até séries de livros. Conforme Spivacow (1995), o sociólogo Gino Germani dirigiu na Abril argentina uma coleção de livros para adultos, Ciencia y Sociedad, a partir de 1945, que, sem êxito, teve seu projeto encerrado em 1948 e o catálogo vendido para a Editora Paidós.

A perspectiva de Cesar Civita em expandir suas ações para outro país não era apenas oportunidade de negócio, mas também o receio de que uma radicalização na política peronista na Argentina pusesse todas as suas realizações a perder. Não estava errado; mas a necessidade de sair de Buenos Aires só ocorreu, de fato, aproximadamente três décadas depois, em 1976. O período de ação de Cesar no Brasil, entre 1945 e a fundação da Editora no país, é obscuro, devido à pouca disponibilidade de dados, mas é provável que tenha procurado estudar o mercado e estabelecer contatos para a viabilização de seu projeto de expansão da editora.

O contrato social da Editora Abril Ltda. foi assinado no dia 16 de dezembro de 1947, conforme o Diário Oficial do Estado de São Paulo (SÃO PAULO, 1948), compondo sociedade entre os italianos Enrico Frisoni (acionista majoritário, com 48\% das ações); Enrico Rimini (com 20\%); Piero Kern e Marcello Frisoni (com 16\% cada). A nova empresa possuía sede à rua Libero Badaró, 158, na sala 2202 do $22^{\circ}$ andar. Tinha por atividades-fim a editoração, "[...] edição, importação e exportação de livros, opúsculos, etc”. Piero Kern e Marcelo Frisoni já eram sócios, no Brasil, da empresa "Kem Comércio e Indústria S. A.", e este último e Enrico Frisoni possuíam, desde 1939 (BRASIL, 1939), uma empresa de preparação e enrolamento de fios para tecidos. É estranho, como também notou Cabral (2006), que uma empresa de 
comunicação tenha sido registrada em desacordo com a legislação vigente (Constituição de 1946), que, em seu artigo 160, proibia estrangeiros ou sociedades anônimas de possuírem empresas jornalísticas ou de radiodifusão no país (BRASIL, 1946).

A nova editora dedicava-se à importação de materiais educativos para crianças, impressos na Argentina. Já nos primeiros anos, apareceram problemas. $O$ Diário Oficial da União, na véspera do Natal de 1948 (BRASIL, 1948), publicou a demanda entre os sócios italianos da Abril e a Comissão de Tarifas, devido a um conferente ter taxado o que, na visão dele, não seriam livros e, portanto, não estariam abrigados de isenção legal de impostos de importação. Tratavam-se "de estampas recortadas, em que as páginas são apenas duas únicas folhas de cartolina da mesma espessura da figura principal recortada e representando a figura de 'Mickey Mouse', divulgada pelo desenhista Walt Disney”. A decisão do secretário da Comissão foi de considerar os volumes como livros e isentar os impostos. Os importadores declararam que os livros seriam para o ensino infantil e, embora não seja possível conhecer o teor e a forma das publicações, é seguro dizer que foram os primeiros impressos de personagens Disney a circularem no Brasil sob responsabilidade da Editora Abril.

É provável que os exemplares apreendidos fossem alguns cadernos escolares com personagens Disney ou estivessem relacionados às primeiras edições da Editora Abril no país. Estas publicações, baseadas em edições idênticas já lançadas na Argentina pela Editorial Abril, pouco conhecidas e ignoradas pelas biografias institucionais da empresa, circularam antes da vinda de Victor Civita ao Brasil, sendo vendidas em bancas de jornais ou livrarias a preços módicos (entre $\mathrm{Cr} \$ 5,00$ e $\mathrm{Cr} \$ 10,00)$. Entre os livros deste primeiro período, encontram-se a Coleção Pequenos Grandes Livros (baseada em Pequeños Grandes Libros, publicada pela Editorial Abril, inspirada em Better Little Books, editada nos EUA pela Whitman Publishing Company), de livros em formato reduzido e com capa dura, vendidos em bancas de jornais, que ficaram conhecidos por "tijolinho". Também foram editadas as coleções A Janelinha (La Ventanita, pela Editorial Abril); Contos de Abril (Cuentos de Abril, inicialmente Pretzel, na Argentina); e Coleção Eu Sou (Yo Soy, pela Abril argentina), todas vendidas em livrarias. 
As obras foram produzidas antes mesmo da fundação da editora. A impressão dos volumes de Contos de Abril foi concluída no dia 1ํ de outubro de 1947, dois meses antes da constituição da empresa. Os livros foram impressos em Buenos Aires pela Cia. Gral. Fabril Financeira S. A. e distribuídos no Brasil pela Editora Brasiliense (Figs. Figura 1 e 2). Entre os primeiros títulos lançados pela coleção estavam Pinóquio; A Viagem Maravilhosa dos Quatro Chinesinhos; O Porquinho Prático; Aventura entre Flores; Os Sete Cabritos; O Gato de Botas; Branca de Neve e os Sete Anões; O Irmão Rabinho; O Circo de Donald; A Pequena Polegar; O Patinho Feio; e O Peixinho de Ouro.

Figura 1 - Capa e contracapa de O Gato de Botas, Coleção Contos Abril (1947)
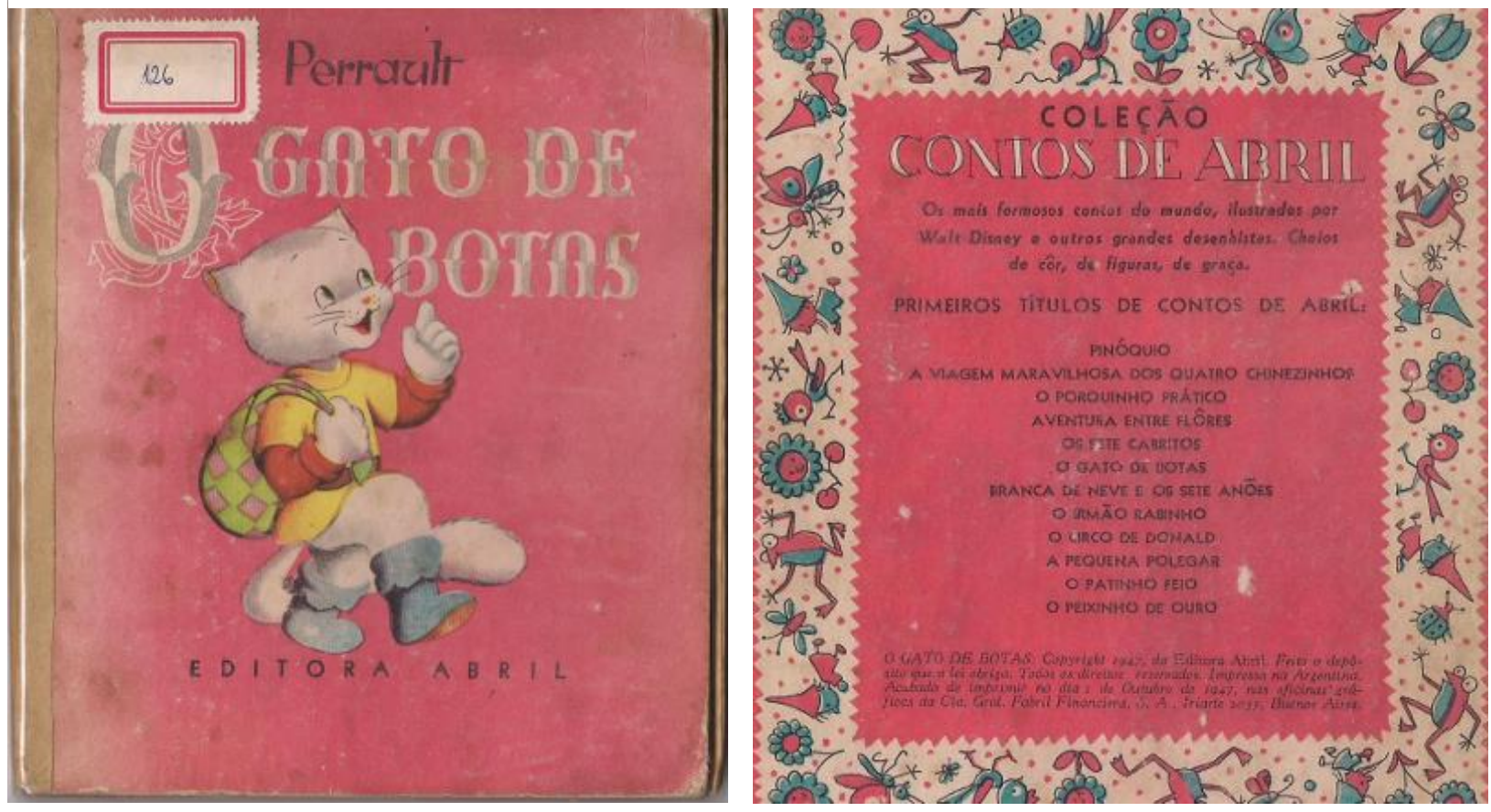

Fonte: acervo pessoal do autor. 
Figura 2 - Página interna e contraguarda da contracapa de $O$ Gato de Botas, Coleção Contos Abril (1947)
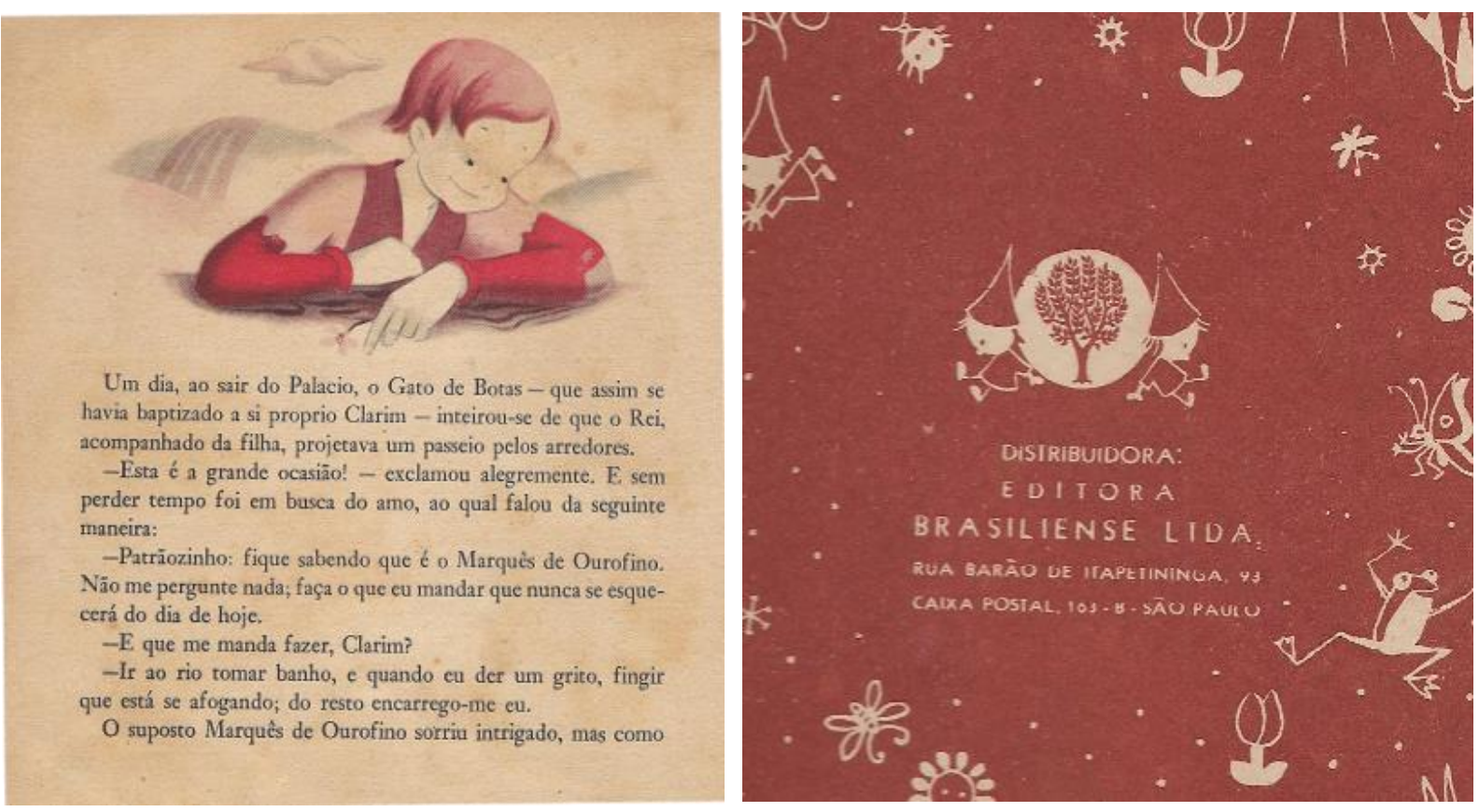

Fonte: acervo pessoal do autor.

A partir de sua fundação até o início de 1950, a Abril permaneceu com um pequeno catálogo de livretos infantis adaptados, sem muito destaque no cenário editorial. Os rumos da editora mudaram quando Victor Civita $^{9}$, então chefe de vendas, vice-presidente (MERCADANTE, 1987) e acionista minoritário (MERCADANTE, 1987; TOLEDO, s. d.) de uma fábrica de embalagens para perfumes finos em Nova lorque, pousa em solo carioca no dia 09 de setembro de 1949, em um avião da Panair, provindo de Buenos Aires, de acordo com as indicações em sua ficha de imigração (Figura 3).

Victor estava na capital argentina a convite do irmão, Cesar Civita, naquele momento já bem-sucedido editor de revistas na Argentina com sua Editorial Abril. Cesar havia vislumbrado no gigantesco país vizinho a possibilidade de expandir a empresa e propôs a Victor (informação verbal) ${ }^{10}$, então em férias com a família em

9 Nascido Vittorio, provavelmente em homenagem a sua mãe, Vittoria Carpi Civita, em 1907, na cidade de Nova lorque.

10 Conforme entrevista de Richard Civita concedida ao autor em 23 de setembro de 2016. 
Amalfi, no Noroeste da Itália, que fosse à Argentina para ver se o negócio da edição de livros e revistas lhe interessaria. Interessou.

Victor veio ao país apenas com a experiência no setor de embalagens nos Estados Unidos e na publicação de "[...] uma revista sobre máquinas para oficinas mecânicas" na Itália, em parceria com o irmão (AQUINO, 1986, p. 233), ligada à empresa do pai (MERCADANTE, 1987). A pequena filial brasileira, que importava livros infantis e operava em uma sala no centro de São Paulo e já tinha quase dois anos de atividade quando Victor Civita chegou ao Brasil, seria o embrião do conglomerado que atingiu a marca de mais de 15000 funcionários, superava 200 publicações e imprimia cerca de 200 milhões de exemplares por ano em 1990, no maior parque gráfico da América Latina (ENTUSIASMO..., 1990). 
Figura 3 - Ficha consular de Victor Civita (1949)

REPÚBLICA DOS ESTADOS UNIDOS DO BRASII

MODELO S.C, 139 FICHA CONSULAR DE QUALIFICACXAO

Esta ficha, expedida em duas vias, será entregue à Polícia Maritima e à Imigraçào no pôrto de destino

Admitido em território nacional em caráter ......tem2onǵxio

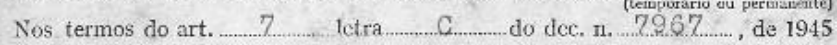

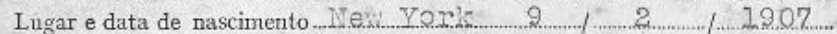

Nacionalidade nort americana Estado civil casado

Filiação (nome do Pai e da Mãe) ……......... Cario Civiț e

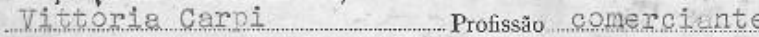

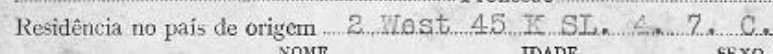

FILHOS
MENORES
DE 18 ANOS

Passaporte n..777728 expedido pelas autoridades deD epartiament

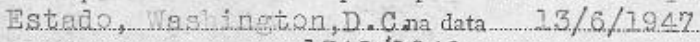

visado sob n $\quad 1342 / 7940$

ASSINATURA DO PORTADOR:

ive. piris

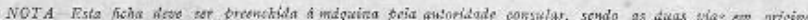

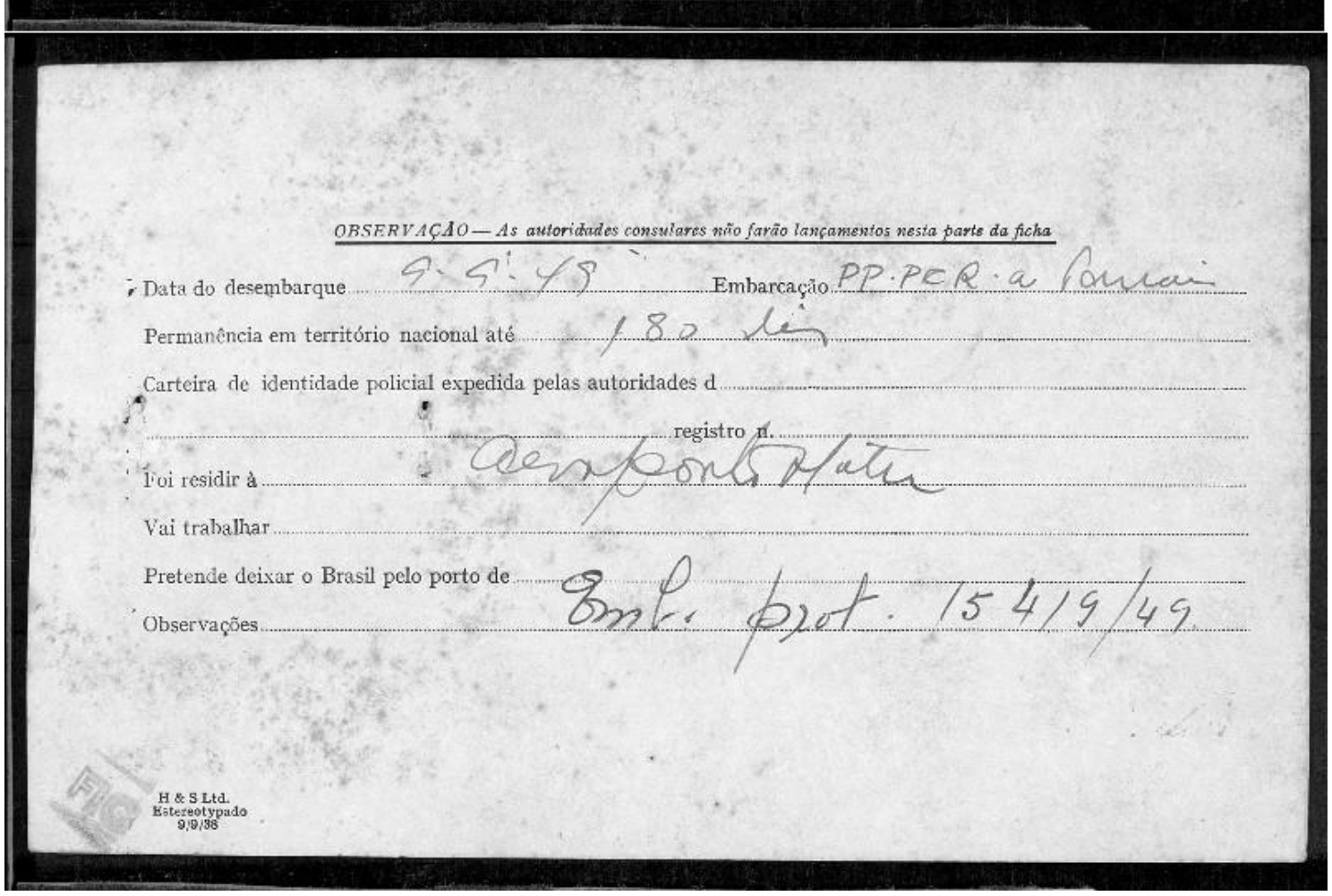

Fonte: Brasil (1949). Disponível em: <www.familysearch.org>. Acesso em: 15 mar. 2016. 


\subsection{A segunda fundação da Abril}

No Brasil, Victor vai primeiro ao Rio de Janeiro e, contrariando a lógica de que a capital federal seria a cidade ideal para uma editora, por concentrar os melhores artistas, jornalistas e profissionais do ramo, desiste de lá iniciar um negócio devido às condições climáticas, que considerava desfavoráveis. Escolhe São Paulo, onde se concentrava o dinheiro e havia um clima bom para o trabalho gráfico-editorial (MERCADANTE, 1987).

Chega definitivamente à São Paulo em dezembro de 1949, hospedando-se, naquela ocasião, no Hotel Senador. A capital, embora pouco proeminente em publicações periódicas, era dotada de um panorama positivo para edição: convergia, conforme indicado anteriormente, grande parte da atividade industrial do país e ampliava sua população pela migração de trabalhadores vindos de outros estados e de cidades de proeminente perfil agrário dentro do Estado. Dispunha, portanto, de capital financeiro e humano para o desenvolvimento de novas indústrias e, na visão de Victor, a indústria editorial e gráfica deveria estar entre elas.

Embora já editasse livros, a Abril não apresentou qualquer publicação periódica durante este primeiro período, que engloba o final de 1947, data de fundação da empresa, até o começo de 1950, quando Victor Civita inicia, de fato, um projeto editorial em solo brasileiro. Conforme depoimento de Richard Civita, filho mais novo de Victor, a Editora Abril foi comprada do tio por seu pai, que estava decidido a iniciar um novo empreendimento no Brasil. De filial da quase homônima casa publicadora argentina, a Abril tornou-se, a partir de 1950, uma editora independente, embora intimamente ligada às publicações de sua irmã. Faltava a Victor, entretanto, recursos para investimento na implantação da estrutura que almejava para a editora. Conforme Scarzanella (2009), em novembro de 1949, dois meses após a chegada de Victor ao Brasil, Cesar envia uma carta a Arnaldo Mondadori, com quem havia trabalhado na Itália, solicitando apoio para o desenvolvimento de uma editora e uma indústria gráfica no Brasil, que carecia de boas publicações e empresas de qualidade no setor. O editor italiano recusa a parceria, o que obriga Victor a recorrer a Nelson A. Rockefeller e sua fundação para desenvolvimento de países latino-americanos, a Economic Basic Economy Corporation (EBEC), operação sempre negada pelo editor, posteriormente. Gonçalo 
Silva Junior (2003) aponta que, na verdade, Victor recorreu a empréstimos com amigos nos Estados Unidos na ordem de 1,5 milhão de dólares.

O fato de Civita ser estrangeiro foi um impedimento para que assinasse os editoriais de revistas e livros publicados pela editora, bem como procurasse não se expor como seu dirigente até que fosse efetivada sua naturalização como brasileiro, em 24 de agosto de 1960 (ARQUIVO PÚBLICO DO ESTADO DE SÃO PAULO, 1980). Já naturalizado, não deixou de enfrentar denúncias sobre o caráter internacional da Abril e de outros estrangeiros comandando veículos de imprensa no Brasil, como as publicadas por Genival Rabelo entre 1961 e 1964, na revista PN, e, com maior alcance, pelos artigos divulgados na Tribuna da Imprensa a partir de janeiro de 1966 e coligidos em livro editado no mesmo ano pela Editora Civilização Brasileira (RABELO, 1966).

Nestes artigos, Rabelo defende que os estrangeiros, com apoio do capital internacional, teriam melhores condições econômicas de concorrência que os editores nacionais, o que resultaria em um monopólio dos canais de imprensa por cidadãos não nativos. Na edição de 11 de dezembro de 1962, o Jornal do Brasil (MONT'ALEGRE, 1962) anunciou, numa coluna de negócios, que a Abril iria estabelecer uma parceria com a Time-Life para a publicação da Revista Panorama, cujo nome o grupo estadunidense já havia, conforme a nota, adquirido da companhia que a publicava em Curitiba. Entretanto, a Abril jamais editou uma revista com esse nome. Genival Rabelo alegou que a publicação não foi efetivada pela Abril/Time-Life porque o diretor da revista paranaense havia pedido alto demais pelo título: 1 milhão de dólares ou $50 \%$ de participação nas ações da editora que seria formada para o lançamento da nova revista (RABELO, 1966).

Em 22 de novembro de 1963, o jornal Correio da Manhã (RJ) (DEPUTADO..., 1963) informava que o Deputado Federal João Dória havia acusado revistas da Abril (Quatro Rodas, Cláudia e Capricho) e agências de propaganda estrangeiras de serem contrárias à Constituição brasileira. Uma Comissão Parlamentar de Inquérito (CPI) foi constituída para investigar a relação do capital estrangeiro com meios de comunicação no Brasil e, devido a isso, a Editora veria seu nome envolvido em uma série de publicações sobre o tema em diversos jornais de grande circulação do país (em especial O Estado de São Paulo (SP); Tribuna da Imprensa (RJ); Jornal do 
Brasil (RJ); Correio da Manhã (RJ) e toda a cadeia dos Diários Associados, de Assis Chateaubriand, até pelo menos o início da década de 197011, publicando, frequentemente, editoriais e notas em suas revistas e outras publicações para desmentir o fato.

Estabelecido na cidade, Victor Civita inicia o projeto das primeiras publicações da Editora Abril no país. Instala-se, inicialmente, à rua Libero Badaró, 158, em uma sala do $22^{\circ}$ andar $^{12}$. Com uma pequena equipe, dirigiu a edição da hoje desconhecida Raio Vermelho ${ }^{13}$, que foi às bancas em maio de 1950, e Pato Donald, publicada dois meses depois, em julho do mesmo ano. O primeiro volume de Raio Vermelho é creditado à Editora Primavera, uma espécie de nome fantasia da Abril. Ambas já eram publicadas por Cesar na Argentina: a primeira, desde 1949, como Rayo Rojo, e a segunda, desde 1944, como El Pato Donald. Pato Donald, em anúncios veiculados na imprensa nacional (Figura 4), na ocasião de seu lançamento, aparece sob a responsabilidade de Jerônimo Monteiro. Victor Civita, por sua condição de estrangeiro, não é citado na peça publicitária.

11 Nelson Werneck Sodré, no capítulo "O controle da Imprensa", que encerra sua obra de maior fôlego, História da Imprensa no Brasil (1999), trata com maiores detalhes sobre as acusações de intervenção estrangeira nos meios de comunicação nacionais durante a década de 1960, pré e pós Regime Militar.

12 Não se pôde verificar se a sala era a mesma indicada no contrato social de fundação da Abril, embora a coincidência entre o endereço e o andar façam crer que seja provável tratar-se do mesmo espaço.

13 A revista Raio Vermelho não é apresentada em nenhuma biografia oficial da editora, nem em entrevistas de dirigentes como a primeira publicação do grupo, devido ao fato de não ter sido bemsucedida. 
Figura 4 - Anúncio do lançamento de

Pato Donald (1950)

\title{
"O Pato Donald"
}

\author{
Sob a direçrio do escritor e * : \\ nalista Jeronimo Monteirn, at i.t. \\ de aparecer nesta capital a re's- \\ to Infantll "O Pato Donald'. "i':A \\ apresenta historias em quaciti..neg \\ vividas pelos conhecidos persona- \\ gens de Walt Disney, entre eles \\ Pluto, Donald, Mlckey. zé Carloca \\ e outros. \\ Impressa em cores, a novel pubil. \\ caçấo, ao mesmo tempo que mar- \\ ca um indlce do desenvolvimento \\ da industria graflca brasllelra, cer- \\ tamente será recebida com N⿴囗十 \\ alegrla pelo publico infantll.
}

Fonte: Folha da Manhã (1950, p. 8). Disponível em: <http://acervo.folha.uol.com.br/>. Acesso em: 29 abr. 2016.

Victor adota a estratégia de supervisionar pessoalmente as bancas de jornais para manter uma relação estreita com jornaleiros e melhorar a exibição de suas revistas. Gostava de dizer que uma de suas funções nos primeiros anos da empresa era "inspetor de bancas". Sua dedicação à editora se reflete diretamente no aumento de vendas e na necessidade da busca por um espaço maior para o escritório. Segundo Gonçalo Silva Junior (2003), a editora transfere-se para três salas contíguas na rua João Adolfo em janeiro de 1951. Entretanto, os créditos do sétimo número de Raio Vermelho indicam que, já em novembro de 1950, a Abril estava no nono andar do número 118 daquela rua, onde ficaria até 1964.

Conforme Victor Civita contou a Cláudio de Souza, um dos primeiros funcionários da empresa (SILVA JUNIOR, 2003), o nome da editora refletia o início da primavera no continente europeu, e seu símbolo representava "[...] a fertilidade, a própria imagem da vida". O símbolo da Abril brasileira, em seus primeiros anos, era o mesmo da irmã argentina: uma pequena árvore com o nome da editora abaixo. Boris Spivakow (1995, p. 26, tradução nossa), criador do nome da editora de Cesar, aponta sua origem conforme sua intenção quando o desenvolveu. $O$ nome Abril foi 
escolhido por dois motivos: "por seu som alegre e vibrante e porque era, de alguma maneira, sinônimo de juventude", além de ser um mês em que é primavera no hemisfério Norte. Entretanto, apenas em 1958 a pequena árvore da Abril passou a estampar as capas das revistas publicadas pela editora. Em agosto de 1967, o logotipo sofreu mudanças na estrutura e as folhas da árvore passaram a ser maiores e em menor quantidade. Quanto à cor, até 1967, variava de acordo com o tom da capa em que seria empregado o logo, sendo encontradas em publicações pesquisadas o verde, azul, rosa, vermelho e preto (Figura 5). A partir de 1967, com a reformulação, passou a ser impresso, conforme os exemplares que conseguimos acessar, em preto, branco, verde ou vermelho, novamente de acordo com o tom da capa. A única exceção com relação ao logo era a revista Realidade, que não apresentava o símbolo da editora, limitando-se a indicar em sua capa a frase "Uma publicação da Editora Abril”.

Figura 5 - Evolução do símbolo

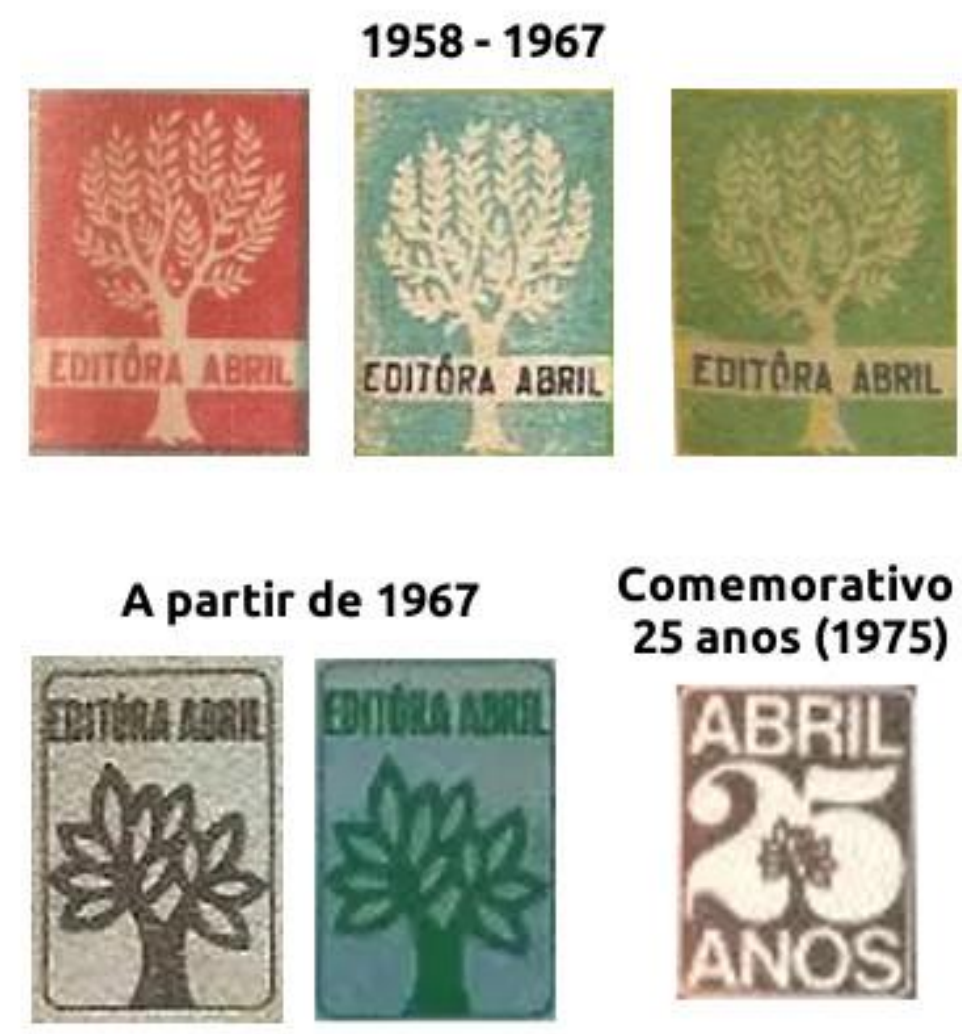

Fonte: acervo pessoal do autor. 


\subsection{Dominando o ciclo: editora, gráfica e distribuidora}

No mesmo período em que se transferiu para um escritório maior, a Editora deu seu maior passo desde o início de suas atividades. Para realizar o projeto editorial pretendido por Victor Civita, era necessária uma gráfica à altura de imprimir em offset a quatro cores e em volume suficiente para atender ao mercado que a editora criaria nos anos seguintes. Surgiu, então, em escritura lavrada em 24 de outubro de 1950 (SÃO PAULO, 1950), a Sociedade Anônima Impressora Brasileira (SAIB) (Figura 6), sociedade composta por Victor Civita e sua esposa Sylvana Civita, acionistas majoritários (1000 ações cada), e os italianos Guido Guastalla, Antonio Ronchi, Aldo Magnelli, Eugenio Rosenberg Colorni e o brasileiro Francisco Finamore (100 ações cada).

A primeira gráfica do grupo, montada a partir do prédio de uma antiga fundição na Rua dos Portugueses, bairro de Santana, zona Norte de São Paulo, dispunha de uma pequena rotativa, uma linotipo, duas guilhotinas de papel, uma impressora de duas cores e uma grampeadeira (SABADIN; PINHEIRO; GABRIELLI, 1982) e uma impressora Webendorfer importada, capaz de imprimir 160 mil páginas por hora ${ }^{14}$. Quando começou suas atividades de fato, em 1952, tornou-se referência em serviços gráficos na cidade de São Paulo, com capacidade produtiva muito superior às necessidades da editora, o que levou a SAIB a oferecer suas oficinas para trabalhos externos a partir de 1956, conforme Silva Junior (2003), embora a gráfica tenha necessitado de muitos ajustes até atingir boa eficiência. $O$ bom desenvolvimento dos negócios editoriais fez com que a Abril, em 1959, começasse a construir o novo prédio da SAIB, na Marginal Tietê, com obra executada pela Racz Construtora, que seria inaugurado em 1964.

14 Conforme dados obtidos em <http://grafica.abril.com.br/historico.php>. Acesso em: 17 fev. 2016. 
Figura 6 - Primeira sede da S.A.I.B., na Rua Nova dos Portugueses

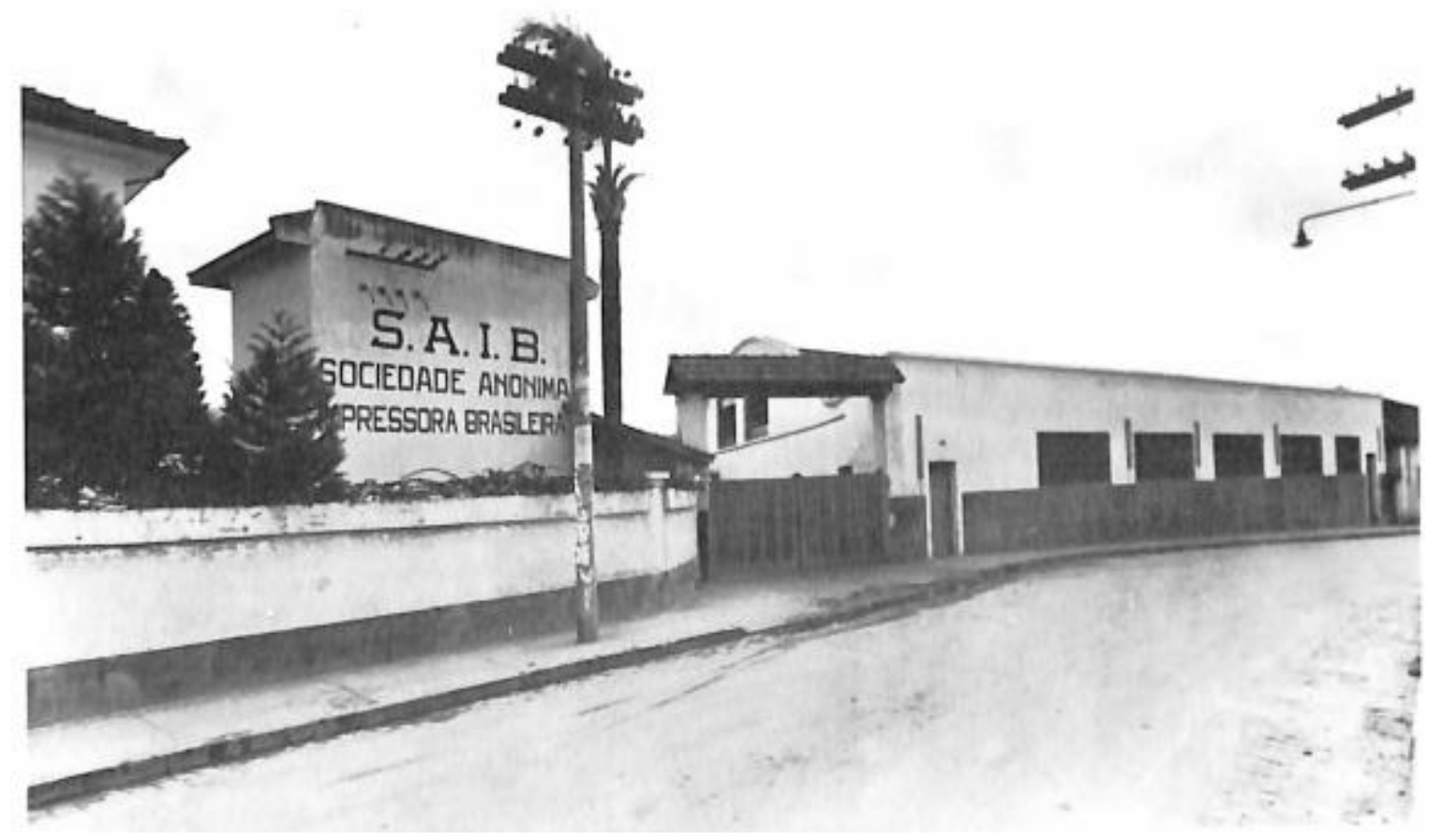

Fonte: Mercadante (1987).

Civita, que já possuía editora e gráfica, ainda enfrentava a dificuldade em distribuir as revistas naquele período. Os pontos de vendas ainda eram escassos, como foram as livrarias 40 anos antes, quando Monteiro Lobato teve a ideia, já mitificada na história editorial brasileira, de escrever uma carta-proposta onde ofereceu a comerciantes em todo território nacional, independentemente do ramo de atuação, a possibilidade de vender em consignação as publicações de sua editora. O próprio Lobato comenta esta ação ${ }^{15}$ :

A mercadoria que produziamos - "livro" - era uma mercadoria sem bocas de escoamento. Não havia pelo país inteiro mais que umas 40 ou 50 livrarias. Ora, como pensar numa industria assim, sem saida para os seus produtos? E a Grande Ideia veiu: romper aquela barragem, rasgar seteiras na muralha, levar os livros até onde houvesse um grupo de fregueses potenciais. [...] com uma circular que eu redigi - e que hoje eu dava um bom dinheiro para te-la em meu arquivo. Essa circular marcou a virada de esquina da nossa cultura. Mandamo-la a uns 1300 negociantes cujos endereços com algum esforço obtivemos: 1300 negociantes de 1300 cidades e vilas do Brasil dotadas de serviço postal - donos de pequenas papelarias, donos de bazar, de farmácias, de lojas de armarinho ou de fazendas e até de padarias... A circular propunha-lhes um negócio novo: a venda duma coisa chamada "livro", que eles receberiam em consignação e, pois, sem empatar dinheiro nenhum. Vendida que fosse a tal misteriosa mercadoria, o negociante descontava a sua comissão de $30 \%$ e nos enviava o saldo. [...] Nenhum dos nomes convidados pela circular recusou o bom

15 Optou-se por manter a grafia original. 
negocio - e passamos de 40 ou 50 vendedores de livros a $1300 \ldots$ (LOBATO, 1955, p. 253-254).

Tendo conhecimento da história desta carta, Cláudio de Souza sugeriu ao chefe a utilização de um sistema parecido, o que foi prontamente aceito por Civita, que, com sua nova versão da carta de Lobato, obteve o retorno de vários interessados em revender suas revistas, para quem os distribuidores foram indicados a atender. Claudio relata que este foi um dos embriões da criação da distribuidora que surgiu alguns anos depois (SILVA JUNIOR, 2003).

Em janeiro de 1959, a editora instalou um escritório comercial no Rio de Janeiro, sede da distribuidora de suas publicações, a Fernando Chinaglia, que foi responsável pelo serviço durante os seus dez primeiros anos de atividade. Civita optou por criar sua própria empresa de distribuição e, após a recusa de empréstimo pelo Citibank, obteve recursos do Banco Nacional (SILVA JUNIOR, 2003) para que, em 1961, a Abril, que já era responsável pela edição e impressão de seus produtos, inaugurasse a Distribuidora Abril, o que the garantiu controle efetivo sobre todo o ciclo produtivo das edições e que, em 1982, se transformaria na DINAP (Distribuidora Nacional de Publicações).

Em 15 de agosto de 1960, chegava às bancas a primeira investida da Editora no setor de livros didáticos: a coleção mensal de revistas de bolso Diversões Escolares, publicada pela recém-criada Abril Didática (Editora Abril Didática Ltda., constituída em 24 de maio de 1960). Originalmente editada na Itália pela Fratelli Fabbri, foi adaptada a temas nacionais, retratados já no número inaugural. Entre eles, um artigo condensado sobre a história do Brasil, "de Cabral à Brasília"; seções como "Viajando pelo Brasil", em que mapas de Estados brasileiros eram apresentados para serem coloridos e identificados de acordo com suas condições geográficas; e "Fototeste", em que uma imagem representativa do país era apresentada e os leitores deveriam responder a algumas questões sobre ela, enviar as respostas por carta à editora, que sortearia, entre os que acertassem as questões, uma assinatura anual da revista.

A revista parece não ter alcançado o sucesso esperado e teve seu nome alterado para Diversões Juvenis a partir do número 18, em fevereiro de 1962. O excesso de textos didáticos não atraiu o público pretendido, crianças em idade 
escolar, que preferiam as histórias em quadrinhos da própria editora em seu momento de lazer. A mudança no nome, abolindo o "escolar", com o intuito de desvincular o periódico da instituição da escola, e adoção do termo "juvenil", mais atrativo, embora não fosse alterada a identificação de ano e numeração, herdados do título anterior, não foi suficiente para fazer a editora continuar apostando na publicação. Teve sua circulação encerrada no número 30, em janeiro de 1963, e foi relançada dez anos mais tarde, agosto de 1973. O selo Abril Didática não foi mais utilizado em nenhuma outra publicação e a Editora só voltaria a publicar obras didáticas cinco anos depois.

Em 1964, 14 anos após o início de fato das atividades editorais, a Abril já não era mais apenas uma editora, mas uma empresa em vias de se tornar um conglomerado, com divisões próprias que atendiam às próprias necessidades e oferecia a capacidade excedente para prestar serviços a outras companhias. Em 1966, conforme Rabelo (1966), contava com 18 publicações em circulação, com impressão de 4,5 milhões de exemplares mensais. Dessa maneira, a Abril era uma empresa muito bem estabelecida no setor editorial e industrial paulista e com uma distribuidora de nível nacional quando começou a investir em um nicho que marcaria quase duas décadas de história da empresa: os fascículos e livros vendidos em bancas de jornal.

\subsection{A grande aposta: surgem os fascículos}

Embora os executivos da Abril acreditassem que os brasileiros não estivessem familiarizados com os fascículos (APOSTA..., 1980), o termo já era utilizado em periódicos que circulavam no país desde 1817. Naquele ano, o "Correio Brasiliense", então editado e impresso em Londres, trazia a notícia do lançamento do "Fasciculo de Dissertaçoens Juridico Praticas", de autoria de Manuel de Almeida e Sousa de Lobão. A "Gazeta do Rio de Janeiro" informa, no ano seguinte, que a mesma publicação, impressa em Lisboa, encontrava-se disponível para compra na loja da Gazeta. Em 1848, o "Diário do Rio de Janeiro" aponta que foram remetidos "[...]ao bibliothecario da bibliotheca[...]" "[...] 6 exemplares do fascículo $6 .^{\circ}$ da Flora Braziliensis publicada pelo Dr. Martius[...]", enviados de Viena pelo ministro da corte. 
A publicação de livros em fascículos, vendidos nas livrarias, já acontecia em 1890, como informava o jornal "A República", na divulgação do romance "Vencedores e Vencidos", cujo primeiro fascículo estava "[...] à venda na conhecida Livraria Queiroz [...]" (VENCEDORES..., 1890). No dia 25 de abril de 1909, o "Jornal do Brasil" anuncia a publicação, pela "Revista da Semana", do romance em fascículos "Caminho da Morte", de Maurice Montegut. A própria "Revista da Semana", na edição daquele mesmo dia, oferece mais informações sobre a publicação: teria "[...] muitas e lindas illustrações, sendo algumas a cores" e os fascículos seriam "[...] nitidamente impressos em bom papel, sem augmento de preço". Ainda, ao fim da publicação, "[...] as [sic] pessoas que apresentarem todos os fasciculos será entregue uma linda capa impressa a cores" (CAMINHO..., 1909). Fascículos, distribuídos em livrarias e bancas de jornais, com encadernação após completa a coleção: modelo muito semelhante ao que a Abril lançaria 36 anos depois.

O termo fascículo foi usado, no Brasil, para referir-se a publicações periódicas em quantidade reduzida de páginas, no sentido mais próximo ao de livretos seriados, num primeiro momento, e de revistas, posteriormente. Era relativamente comum já na década de 1950, período em que a Hemeroteca Digital Brasileira da Biblioteca Nacional aponta 3495 registros para o termo "fascículo". A palavra era, portanto, conhecida, ao menos entre os leitores de jornais e periódicos da época. $A$ novidade dos lançamentos da Abril estava na forma de publicação e de circulação destas edições.

Segundo a definição do dicionário Houaiss, fascículo é "cada um dos cadernos ou folhetos que integram uma obra maior e que vão sendo publicados por partes". A etimologia da palavra, segundo o mesmo dicionário, indica que sua origem está no termo latino "fascicŭlus,i no sentido de 'molhinho, feixinho, fascículo', dim. de fāscis,is no sentido de 'feixe, ajuntamento'". Para os objetivos deste trabalho, de acordo com o que foi editado pela Abril Cultural, compreende-se como fascículos os cadernos de publicação periódica que compõem um ou mais volumes de uma obra maior.

O modelo de publicação de livros em fascículos adotado pela Editora Abril é anterior à sua popularização no Brasil. Foi baseado nos fascículos desenvolvido na 
Itália, onde as restrições econômicas não permitiam a uma parcela dos consumidores do país comprar livros ou coleções prontas à vista. Entre as décadas de 1950 e 1970, assim como no Brasil, houve um importante processo de industrialização e urbanização do país europeu, o que propiciou o surgimento de novos públicos para produtos culturais. A primeira editora a investir no formato de fascículos na Itália foi a Fratelli Fabbri Editori, que, em 1958, lançou nas bancas a coleção Conoscere, dividida em 192 fascículos com 16 páginas em média cada um (CAROTTI; ANDRIANI, 2010).

Bem antes do primeiro fascículo da Abril ir às bancas de todo o país, Civita já conhecia o modelo de edição e havia se preparado para lançá-los. Esperou o momento em que a editora teria condições de sustentar um projeto de custo tão alto e que demandaria uma estrutura robusta para que o volume de oferta o tornasse viável. Em 1961, com a empresa bem estabelecida e com gráfica, distribuição e redação própria, já era possível apostar no negócio dos fascículos. Para isso, conforme Gonçalo Silva Junior (2003), Cláudio de Souza foi enviado à Argentina para estudar a publicação de Conocer, versão portenha de Conoscere, publicada pela editora Codex. Voltou e desenvolveu o projeto da coleção, que foi lançada cinco anos depois, como o segundo produto em fascículos da Abril.

A primeira coleção da editora a ir às bancas foi uma Bíblia, livro comum na casa da maioria dos brasileiros, predominantemente católicos no período. $O$ diferencial encontrado pela equipe de Civita foi trazer da Itália o modelo impresso pela Fratelli Fabbri, que editou La Sacra Bibbia, em grandes e luxuosos volumes fasciculares (31 cm, ilustrados) entre 1963 e 1965. Possuir uma bíblia em grande formato e vários volumes, possíveis de serem adquiridos devido à fragmentação proposta pelos fascículos, parecia ser o que Victor considerava como um produto com grande mercado. Entretanto, outros integrantes da editora não pareciam concordar com o chefe. Conforme depoimento de Victor ao projeto História Empresarial Vivida (AQUINO, 1986), em uma reunião, ele pediu a 12 pessoas que decidissem entre a publicação da Bíblia em grandes volumes, ilustrados em cores, mais dispendiosa para se produzir, ou de uma versão menor e mais econômica, voltada aos jovens. Todos optaram pelo formato reduzido, provavelmente acreditando não haver público para o outro. Civita optou pela bíblia de luxo e a decisão decaiu sobre sua escolha. 
Para Richard Civita, entretanto, a história não aconteceu dessa maneira. A reunião não contou com 12 participantes, mas apenas 5 , do alto escalão da editora: Victor, Roberto, Richard, Luis Carta e Domingos Alzugaray. Victor tinha conhecido na Itália, em 1964, La Sacra Bibbia. Comprou os direitos da Fratelli Fabbri e estava decidido a publicá-la no Brasil. Ao apresentar a ideia na reunião, os outros integrantes Ihe disseram não ser viável fazer uma Bíblia de luxo e colocá-la em fascículo. O público não teria a cultura para apreciá-la. Entretanto, conforme Richard, "Victor sempre ditava e decidia, não importa o que os outros diretores dissessem. Ele escutava, ponderava, mas decidia". E estava decidido que a Bíblia seria publicada e nunca houve outra opção econômica voltada aos jovens. A questão que se discutiu na reunião foi o que colocar na quarta capa de cada fascículo e ficou decidido que seriam publicadas imagens de igrejas brasileiras.

Decidida a publicação, foi necessário encontrar traduções da Bíblia para o projeto. Os editores optaram por uma nova tradução, diretamente do aramaico, hebraico, grego e outras línguas, aproveitando-se do projeto iniciado entre os anos de 1950 e 1960 pelos biblistas da Liga dos Estudos Bíblicos (LEB), conforme Konings (2003). Maria Helena Passos demonstra o apuro com que a editora produziu a versão brasileira de sua Bíblia:

"O Marcos Margulies, diretor de publicações em fascículos, se reunia com a equipe tradutora liderada pelo padre Antonio Charbel. Eu entrava na sala", recorda-se Roberto [Civita], "e encontrava, de um lado, um padre lendo a Bíblia em hebraico e, do outro, outro padre lendo a Bíblia em aramaico. Todos discutiam o sentido correto de uma determinada palavra do texto para encontrar o termo certo em português. E olhe que Margulies era judeu sobrevivente de Auschwitz, imagine só!".

A equipe de 28 religiosos, todos doutores laureados em Ciências Bíblicas, incluía dois que faziam o papel de revisores literários e quatro que procediam à revisão crítica. O primeiro volume trazia prefácio escrito por ninguém menos que o então presidente da Academia Brasileira de Letras, Austregésilo de Athayde. Era o aval literário para uma obra que, até então, os brasileiros conheciam apenas como texto religioso - "um empreendimento editorial que honra o Brasil".

Atestava o imortal a "extrema meticulosidade dos tradutores" ao eliminarem "certos preciosismos clássicos que constituíam uma barreira para o entendimento do leitor dos nossos dias." Afinal, São João Crisóstomo, lembrava, já afirmara que a Bíblia era muito mais necessária aos leigos do que aos que praticam religião em mosteiros e conventos (PASSOS, 2003, n.p).

A partir dos apontamentos de Passos (2003), é importante observar que os editores da Bíblia já tinham em perspectiva o público consumidor dos fascículos ao 
traduzir a Obra. Mais do que realizar uma tradução precisa, procuraram, junto aos especialistas, modernizar a linguagem, por vezes hermética, do texto clássico, para que, já ao adquirir o primeiro fascículo, os leitores pudessem sentir-se atraídos e não subjugados por uma linguagem erudita. Este fator, junto ao formato, e à qualidade da impressão, seria um diferencial em relação às Bíblias disponíveis no país.

Figura 7 - A Bíblia Mais Bela do Mundo, encadernada

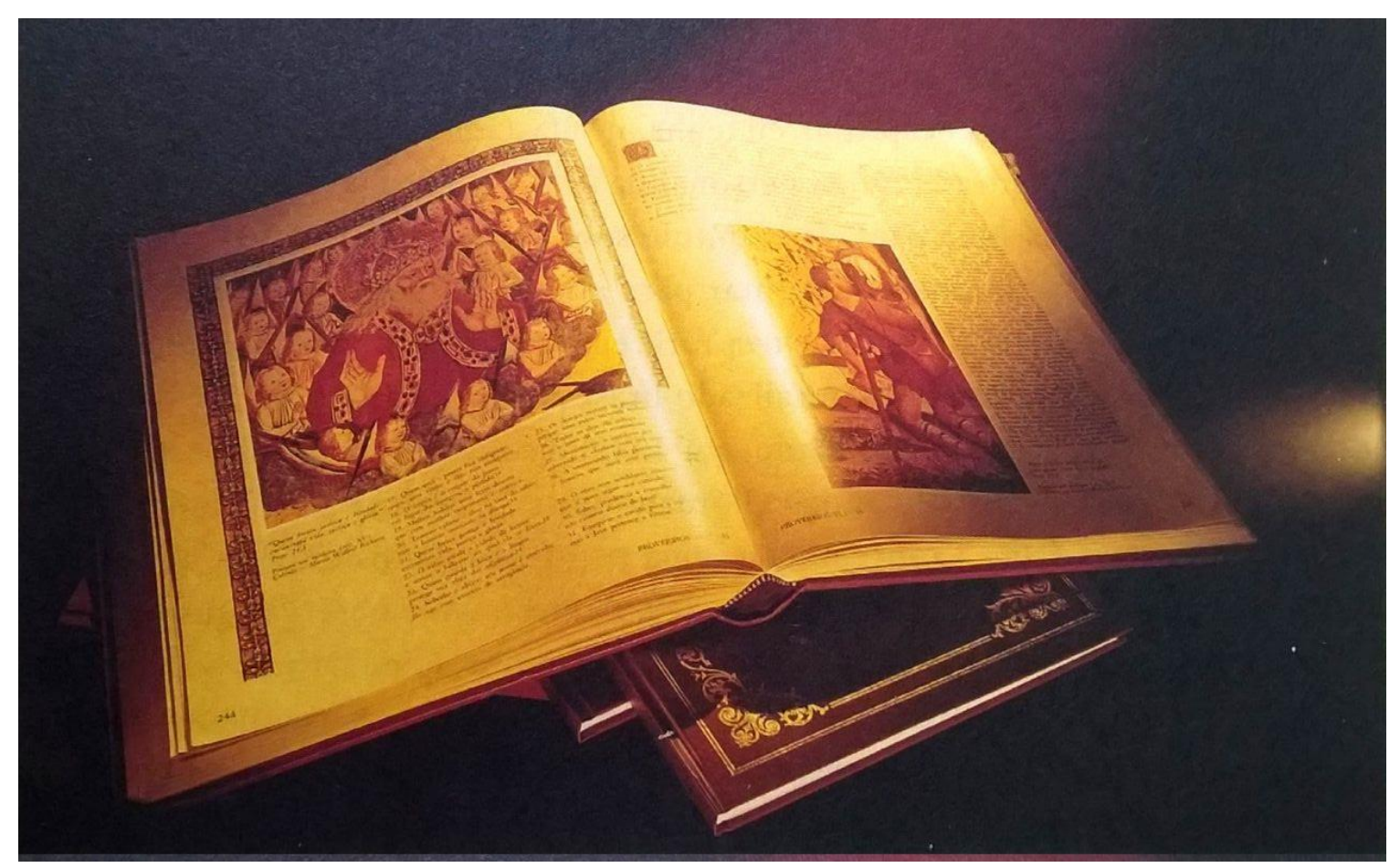

Fonte: Hallewell (2005, p. 678). 
Figura 8 - A Bíblia Mais Bela do Mundo, em fascículos

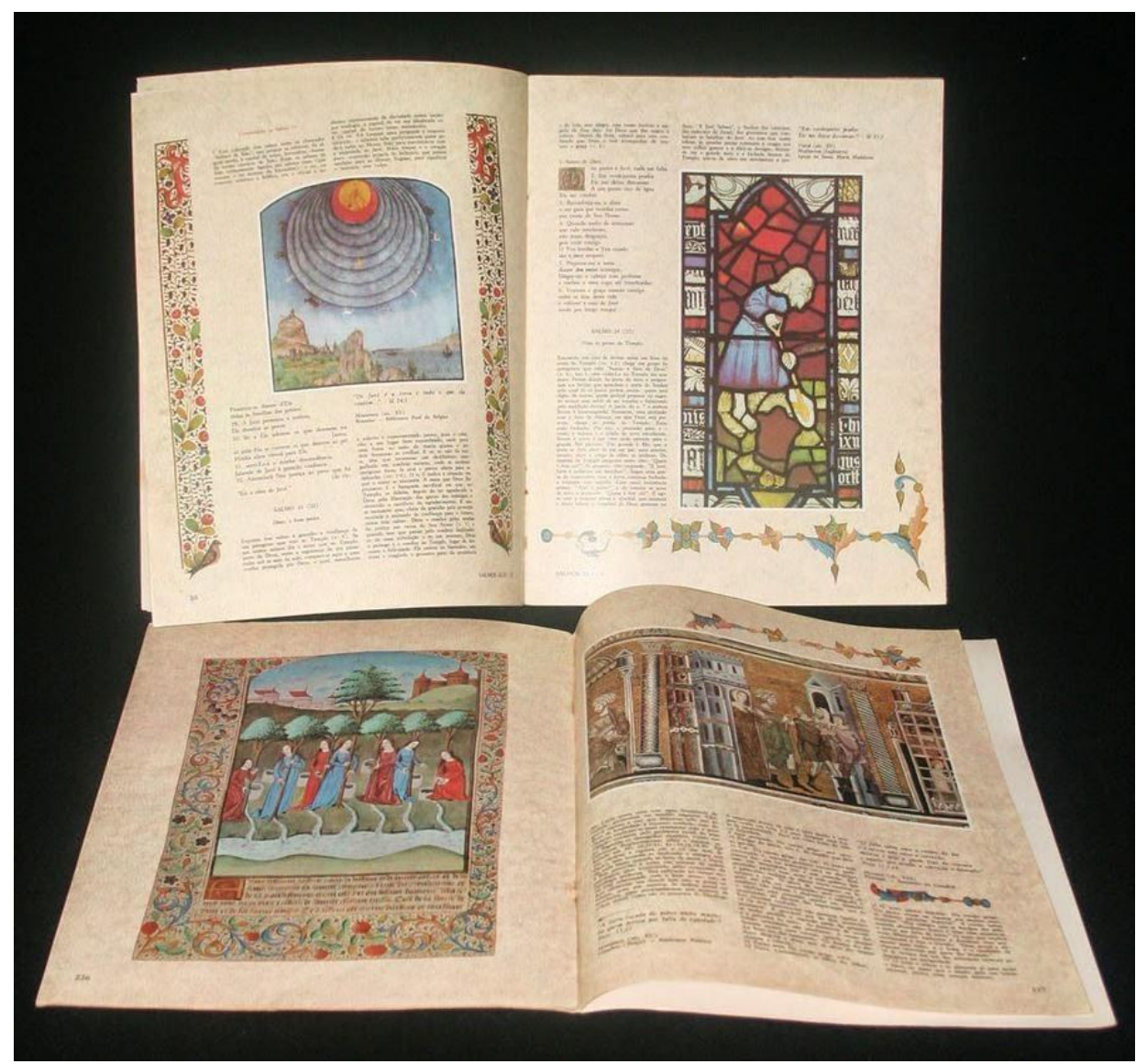

Fonte: Anos Dourados (2015). Disponível em: <http://www.anosdourados.blog.br/2015/02/estante-delivros-biblia-mais-bela-do.html>. Acesso em: 19 abr 2016.

Como um produto editorial completamente diferente do padrão para o segmento, A Bíblia Mais Bela do Mundo (Figs. Figura 7 e Figura 8) foi lançada numa terça-feira, dia 18 de maio de 1965, um dia de tempestade na cidade de São Paulo, em que as bancas estavam fechadas. Isso não impediu que a venda do primeiro fascículo alcançasse a surpreendente cifra de 240 mil exemplares (O HOMEM..., 1965). Também choveu no Rio de Janeiro no dia do lançamento, mas, ainda assim, a Bíblia se esgotou em um dia nas duas capitais, conforme noticiou o Jornal do Brasil (GOMES, 1965), informando que já haviam sido impressos mais 80 mil exemplares para suprir a demanda. A venda volumosa ocorreu devido à confluência de uma série de fatores que serão abordados ao longo do trabalho e que foram responsáveis pelo êxito de muitas outras coleções da Editora, que, de fato, não ocorreu por acaso: o projeto editorial; a qualidade gráfica; a capacidade de distribuição e a propaganda, aliados a um panorama econômico e social favorável. 
Formada por 153 fascículos a serem colecionados semanalmente, a obra completa da Bíblia resultaria em oito volumes, compostos de 2880 páginas e mais de 3000 ilustrações.

Em relação às dúvidas sobre o modelo de publicação, a peça publicitária esclarecia que o formato permitiria uma leitura gradual, devido à periodicidade semanal, e também "[...] mais atraente e interessante [...] aprofundada e meditada", nas palavras de D. Walmor B. Wichrowski, Bispo Titular de Felbes (RS). Além disso, o colecionador era informado de que o formato possibilitava a produção de maiores tiragens e, por consequência, um valor mais acessível. Quanto aos pontos de venda, informa que o reembolso postal não será utilizado, uma vez que as bancas estão largamente presentes em todo o país (ao menos nas praças de circulação das edições) e que nelas se pode encontrar sempre o fascículo atual e os três anteriores. Mesmo que não se conseguisse comprar algum fascículo em bancas, era possível adquiri-los através de pedido à Distribuidora Abril (GOMES, 1965).

A divulgação informa, ainda, que a Bíblia poderá ser encadernada por profissionais do ramo utilizando-se as capas postas à venda periodicamente junto com os fascículos. A coleção se limitaria a 153 fascículos, "nem um a mais, nem um a menos". A garantia de que a coleção não seria abandonada pela editora (e o investimento dos colecionadores desperdiçado) era o nome que a Abril havia construído até aquele ano de 1965. Eram, naquele momento, 15 anos de atividade editorial ininterrupta no país, que lhe valeram o patamar de maior editora do país.

Por fim, o preço, uma dúvida compreensível e esperada. Conseguiria a Editora manter o valor de Cr\$750 do primeiro fascículo, quando, no ano anterior (1964), o país havia atingido o índice inflacionário de 94,12\%? Quais seriam os riscos de o custo do exemplar dobrar caso a alta inflação se mantivesse? Nenhum, conforme o compromisso assumido pela Abril, de manter o valor até pelo menos 1966 e, se possível, "[...] até o fim da obra[...]" (GOMES, 1965).

A Bíblia Mais Bela do Mundo vendeu inicialmente, como já indicado, 240 mil exemplares em seu lançamento, atingindo a estabilidade de vendagem em 160 mil 
exemplares semanais ${ }^{16}$, quando a expectativa era que vendesse 40 mil exemplares iniciais e se estabilizasse em 15 mil (O HOMEM..., 1965). Os conceitos de "vendas iniciais" e "estabilização" são fundamentais para o modelo de negócios dos fascículos. Isto é devido ao cálculo que foi formulado após os primeiros lançamentos de fascículos pela Abril e que permitiam estimar a vendagem em que uma coleção se estabilizaria (média de vendas por número) a partir do volume obtido pelo número inicial. O valor de estabilização, conclui-se, era um percentual sempre constante da venda inicial. Assim, já no lançamento, a Editora poderia prever todo o montante a ser comercializado até o encerramento da coleção, antecipando, por exemplo, se seria deficitária, superavitária ou venderia apenas o suficiente para cobrir os custos. Maria Helena Passos informa que, já

"em junho de 1967, os editores da Abril já conheciam outra curva, negocial. Nas bancas, observaram o desempenho da comercialização dos exemplares, no qual o declínio se estabilizava entre $50 \%$ e $30 \%$ do patamar de largada da coleção. Pela venda do primeiro, já se antevia, com algum rigor, a acomodação futura. O pulo do gato era fazer com que a queda fosse o menos abrupta possível." (PASSOS, 2003, n.p.).

Havia, na produção dos fascículos, a preocupação não apenas relativa à questão formal, mas, também, ao conteúdo. O texto deveria ser claro, conciso e facilmente compreendido mesmo por pessoas com pouca familiaridade com a palavra escrita. Um exemplo foi a preparação da enciclopédia "Conhecer", que durou um ano, e o primeiro fascículo foi reescrito 11 vezes até atingir o "nível de simplicidade e precisão" que os editores almejavam.

\subsection{A Abril Cultural}

A Bíblia Mais Bela do Mundo foi o passo inicial para a grande empreitada que seriam as publicações culturais da Editora Abril. No ano seguinte ao seu lançamento, chegaria às bancas, em setembro de 1966, a Enciclopédia Conhecer, uma enciclopédia ilustrada com periodicidade semanal, mais um sucesso de vendas que deu aos editores a certeza de que este seria um grande nicho no mercado editorial brasileiro: foram 322 mil exemplares vendidos do primeiro fascículo.

16 Conforme Sabadin, Pinheiro e Gabrielli (1982), a venda foi de 150 mil exemplares. Embora sem especificarem se trata-se de venda inicial ou estabilização, é provável crermos que o valor seja referente à estabilização. 
Conhecer foi lançada quando a Bíblia... ainda não havia sido completada, mas o sucesso havia sido tamanho que os editores estavam confiantes de que o segmento de publicações culturais, centrado nos fascículos, não era uma aposta, mas uma realidade, e que ainda havia muito espaço para crescer. A confiança de que muito mais poderia ser publicado era tanta que em Conhecer, pela primeira vez, apareceu nos fascículos o símbolo da Abril Cultural: uma Divisão específica para a edição de obras culturais, fundada em 1966, com sede na rua do Cortume, no bairro da Lapa.

Os primeiros produtos culturais a levarem a assinatura da Abril Cultural, em agosto 1966, foram as coleções de discos Clássicos de Todos os Tempos (10 discos) e Ritmos e Melodias na Música Popular (6 discos), vendidas através de pagamento contra entrega (cobrança domiciliar ao receber o produto). No ano seguinte, completando a Discoteca Abril Cultural, e pelo mesmo modelo de venda, sairiam Era Uma Vez... Vol.1 (6 discos) e Era Uma Vez... Vol. 2 (6 discos) (Fig. Figura 9), ambos com histórias infantis em discos, e Viva a Música (6 discos); Gênios da Música (6 discos); Sempre Carnaval (6 discos) e As 9 Sinfonias de Beethoven (6 discos). Clássicos de Todos os Tempos, Gênios da Música e As 9 Sinfonias de Beethoven foram predecessoras da famosa coleção de discos e fascículos Grandes Compositores da Música Universal (1968) e, junto a Sempre Carnaval, já traziam um libreto ilustrado, uma espécie de fascículo. 
Figura 9 - Peça de divulgação da Coleção Era uma Vez... (1967)

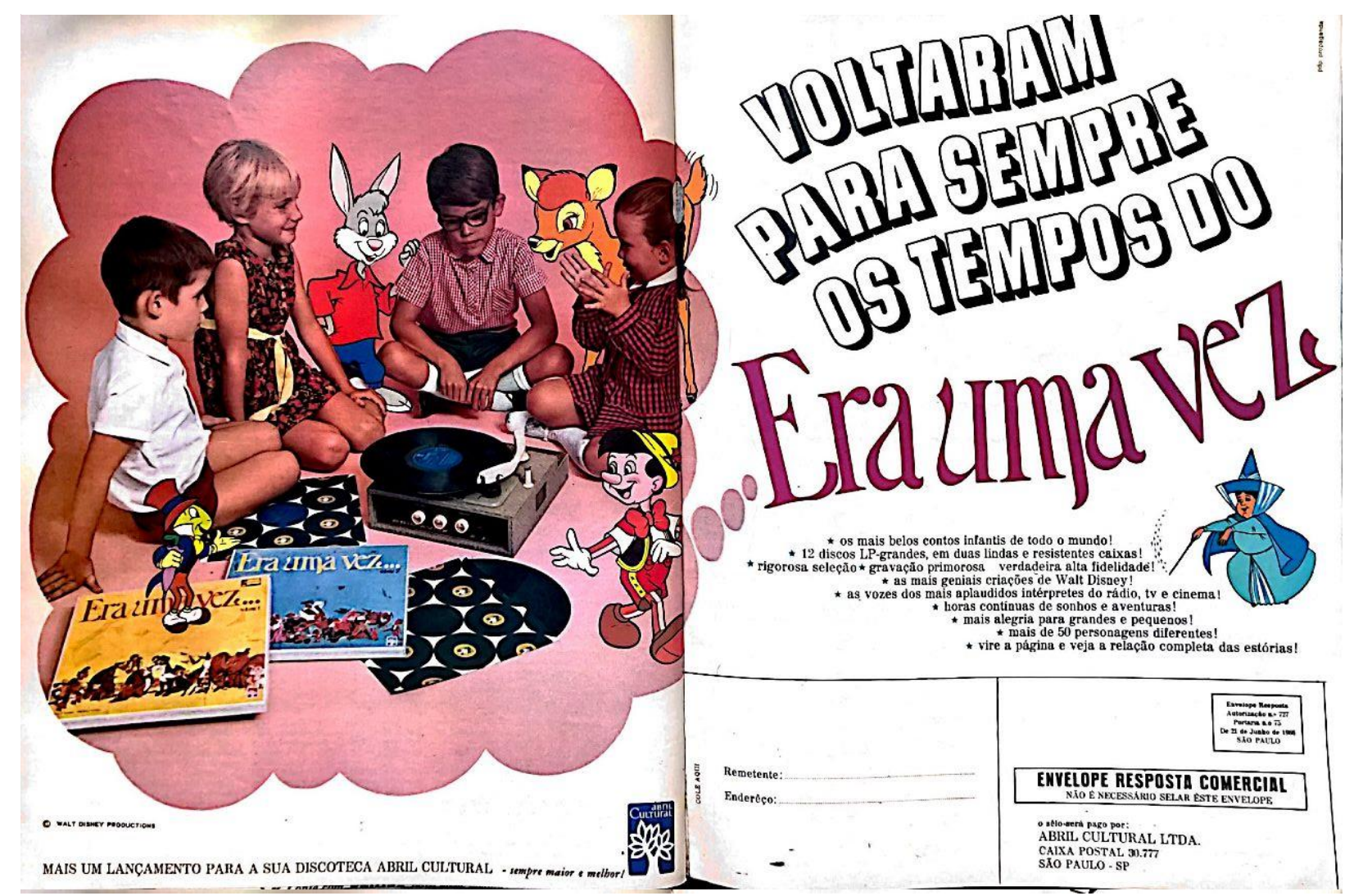

Fonte: acervo particular do autor.

A fundação da Abril Cultural Ltda., em abril de 1966, fez com que o setor de publicações culturais atingisse outro patamar na empresa. Uma equipe de funcionários foi organizada para trabalhar na divisão; estrutura que permitiu à Editora o desenvolvimento de projetos de maior complexidade, e o apuro tanto da forma quanto do conteúdo tornaram-se destaques nos fascículos publicados por ela. Em 1969, o crítico de arte do Jornal do Brasil, Walmir Ayala (AYALA, 1969, p. 2), em um artigo que revisa as melhores iniciativas no mercado editorial de artes do ano anterior, parabeniza Victor Civita e a Editora Abril pela "[...] boa qualidade gráfica, o preço acessível, sobretudo a oferta ampla e descontraída dos álbuns em bancas de jornais [...]", iniciativa que estaria incluindo as massas na elite cultural do país, e levando os leitores "[...] a se expandir humanamente no pleno rendimento de sua sensibilidade". A Divisão ganhou importância na medida em que os fascículos também se tornaram fundamentais para o desenvolvimento econômico da Editora. Em 1972, a Abril Cultural (responsável pelas publicações culturais) já faturava duas vezes mais que a Editora Abril (responsável pelas revistas) (INCESSANTE..., 1972). 
Em 1968, surgiram as primeiras edições para o mercado de livros didáticos sob o selo Abril Cultural. A coleção Alegria de Ler (Fig. Figura 10), composta por livros de leitura para o então ensino primário, foi desenvolvida pelos educadores Adla Neme, Célia Augusta Marques, Celso João Ferreti, Maria do Carmo Guedes e Sylvia Alves, através de seis anos de pesquisas com 600 crianças, que resultaram em um método de ensino "[...] lúcido, adaptado às necessidades do Brasil, integrado no moderno pensamento pedagógico". (CIVITA..., 1968, p. 107). Os livros foram distribuídos através de bancas de jornais e uma peça publicitária de lançamento indicava o preço módico: cada exemplar custava o equivalente a apenas dois maços de cigarros (NCR\$ 1,30). Foram doados, também, em ações do ACISO-EX II (Ação Cívica e Social do II Exército) a regiões inacessíveis do próprio Estado de São Paulo, como o Guaxixi, na llha de Cananeia, litoral Sul do Estado, que foi tema de reportagem pela Revista Realidade (MARÃO, 1970).

Figura 10 - Cartilha A Alegria de Ler

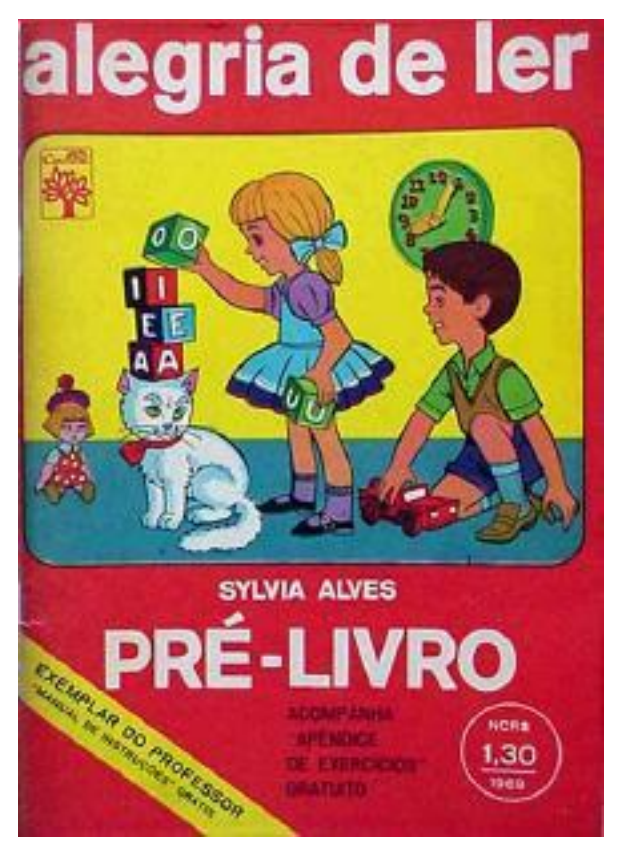

Fonte: Universidade Federal do Rio Grande do Sul. Disponível em:

$<$ http://www.ufrgs.br/faced/extensao/memoria/cartilhas imagens/alegria ler pre.htm $>$. Acesso em: 19 set 2016. 
Pouco após o lançamento da Bíblia, a Abril começa a enfrentar a concorrência de outras editoras que perceberam o potencial do lucrativo mercado dos fascículos. Em junho de 1966, surge a coleção Tecnirama, publicada pela Editora Codex, que, assim como a Abril, possuía uma quase homônima em Buenos Aires (Editorial Codex). Neste primeiro lançamento, a editora adotou a estratégia de reduzir o prazo para se completar a coleção a apenas um ano (a edição da Bíblia, a única na modalidade de fascículos disponível naquele momento, seria completada em mais de três anos). Ainda em 1966, a Codex lança Naturama, enciclopédia em fascículos sobre o mundo animal, e A Segunda Guerra Mundial, um dos primeiros materiais sobre o tema disponível no Brasil. Em setembro de 1967 sairia Georama, enciclopédia geográfica a ser colecionada em 60 semanas. As edições da Codex foram muito bem-sucedidas e as primeiras a rivalizarem com os lançamentos da Abril. Nos anos seguintes, surgiriam outras. Abril e Codex mantinham boas relações, no entanto, como indica o encontro em março de 1967 entre o Diretor da Sucursal Rio da Editora Abril, André Raccah, e Geraldo Mateus, Diretor Geral da Codex (INFORME, 1967).

Em 1969, a Abril publica em fascículos mais uma investida na área da educação: o Ginasial Intensivo - Curso de Madureza - Artigo 99. Em parceria com a recém-inaugurada TV Educativa de São Paulo (TV2, Atual TV Cultura) e Rádio Cultura, os alunos que tivessem interesse no curso intensivo deveriam comprar, na segunda-feira, em bancas de jornais, os fascículos com as aulas a serem transmitidas pela televisão e rádio durante a semana. No primeiro dia de novembro do mesmo ano, a Editora encerrava a publicação de A Conquista da Lua, de Galileu até Hoje, cujos fascículos saíram encartados na Revista Veja, em parte como forma de valer-se do sucesso dos fascículos para alavancar as vendas da revista, então deficitária.

Os anos 1960 encerraram-se acima das expectativas para a Abril: era a maior editora do país, dominava todo o ciclo de produção editorial, com a mais moderna e importante gráfica da América Latina, uma distribuidora de dimensões nacionais e uma gama diversificada de publicações, movimentada pelos melhores profissionais do país, muito bem remunerados por suas atividades. E havia descoberto um grande 
nicho: o das edições colecionáveis em fascículos. Nos seus primeiros quatro anos de atividade, a Abril Cultural publicou apenas fascículos soltos, em capítulos, para a formação de livros a serem encadernados, mas também lançou fascículos com discos. Foi em abril de 1970 que, pela primeira vez, empacotado em plástico celofane, chegaria às bancas de jornais o volume que, em forma e conteúdo, inauguraria uma série de publicações bem-sucedidas durante aquela década: Papillon. 


\section{DO PROJETO À MATERIALIDADE}

Papillon foi, de fato, a primeira experiência da Abril na edição de livros completos, não fragmentados como eram os fascículos, que deveriam ter seus capítulos colecionados ao longo de várias semanas para que se formasse um volume inteiro. Entretanto, a Editora já havia produzido, cinco anos antes, outra publicação cultural na íntegra, que foi envolvida em uma polêmica logo após seu lançamento. Impresso em dezembro de 1964, nas oficinas gráficas da S.A.I.B, com uma tiragem de 55 mil exemplares (FIGUEIREDO, 1965a), no tamanho de $21 \times 27 \mathrm{~cm}, 84$ páginas, capas e contracapas em duas cores (preto e vermelho) e miolo com páginas em preto e branco e algumas a duas cores (preto e vermelho), com papel fabricado pelas Indústrias Leon Feffer, de São Paulo, o livreto Comunismo: de Karl Marx ao muro de Berlim (Fig. Figura 11) criticava negativamente o comunismo e exaltava a "Revolução" de Castelo Branco, justificada, conforme o texto, por uma conclamação popular identificada na "Marcha da Família com Deus pela Liberdade". Esse foi um caso pitoresco e simbólico do perfil dos militares que iniciavam o processo de censura no Brasil naquele período.

A Editora já havia anunciado a obra nos jornais, indicando que as vendas seriam a preço de custo ${ }^{17}$, com o objetivo de advertir, principalmente as classes mais baixas, sobre os "perigos do comunismo". Uma estratégia ao mesmo tempo comercial, por aproveitar-se de um tema em destaque, especialmente após a instauração do Regime Civil Militar no ano anterior; e política, com o objetivo de comunicar aos dirigentes do país seu apoio ao governo e marcar a posição da editora na então efervescente dualidade entre o capitalismo ocidental e o comunismo soviético; a adesão ou oposição ao governo como muitos outros veículos de comunicação fizeram nos primeiros anos do Regime. ${ }^{18}$

17 O valor de capa era de $\mathrm{Cr} \$ 800$. A revista "O Cruzeiro", uma das mais lidas na época, custava Cr\$300. A Revista da Civilização Brasileira, que, apesar do nome, era um livro em formato brochura de mais de 300 páginas, foi vendida por Cr\$1500 em março de 1965.

18 Entre os quais "Folha de S. Paulo" e "O Estado de S.Paulo" (SP), "Jornal do Brasil", "O Globo" e "Correio da Manhã" (RJ). 
Contudo, aparentemente alguns militares não leram nenhum dos anúncios sobre o objetivo e as "boas intenções" da obra, lançada em 03 de fevereiro de 1965. Conforme noticiado pelo Correio da Manhã, em sua edição de 06 de fevereiro de 1965 (ELOGIO..., 1965) e Jornal do Brasil, em edição do dia seguinte (FIGUEIREDO, 1965b), após uma denúncia de que a publicação, bem como sua propaganda (cartazes vermelhos com a foice e o martelo), eram exaltação ao comunismo e seus regimes, o Tenente Rogério Oliveira da Cunha, "[...]escrivão dos IPMs [Inquéritos Policiais Militares] do setor de subversão e comunismo[...]", realizou na sucursal carioca da Editora uma busca e apreensão da obra, autorizada pelo Coronel Gerson de Pinna, com ordens de prender a quem resistisse. Sebastião Martins, gerente da sucursal, precisou convencê-lo de que o conteúdo era o inverso do imaginado, tendo sido, inclusive, escrito por autores estadunidenses. Mesmo com o risco de ter a edição apreendida, "Comunismo: de Karl Marx ao muro de Berlim" foi, naquele momento, considerada a maior tiragem para um livro no Brasil, conforme Miranda (1965), embora em seu formato e extensão estivesse mais próxima de uma revista do que de um livro.

Uma semana após o lançamento de Comunismo, a Abril publicou outro livreto de formato semelhante, mas de qualidade gráfica inferior, denominado Churchill: Herói de Nosso Século (Fig. Figura 11). Medindo 29 por $21 \mathrm{~cm}, 100$ páginas, com capas e miolo em preto e branco, foi impresso também nas oficinas gráficas da S.A.I.B, em fevereiro de 1965. Escrita por Raymond Carter, é uma biografia ilustrada que exalta o então recém falecido ex-primeiro-ministro inglês, reconhecido principalmente por sua atuação durante a Segunda Guerra Mundial e aliança com os Estados Unidos durante o conflito. Esta edição foi a última iniciativa da Editora em produzir, durante a década de 1960, um volume completo, único e não colecionável. A próxima publicação deste tipo ocorreria apenas com o lançamento de Papillon, de Henri Carrière, obra literária best-seller e de grande apelo popular no início dos anos 1970, impressa em formato de livro, numa brochura convencional (2B - 16 por $23 \mathrm{~cm}$ ). 
Figura 11 - Primeiros livros individuais, ainda em formato de revista, lançados pela Editora Abril
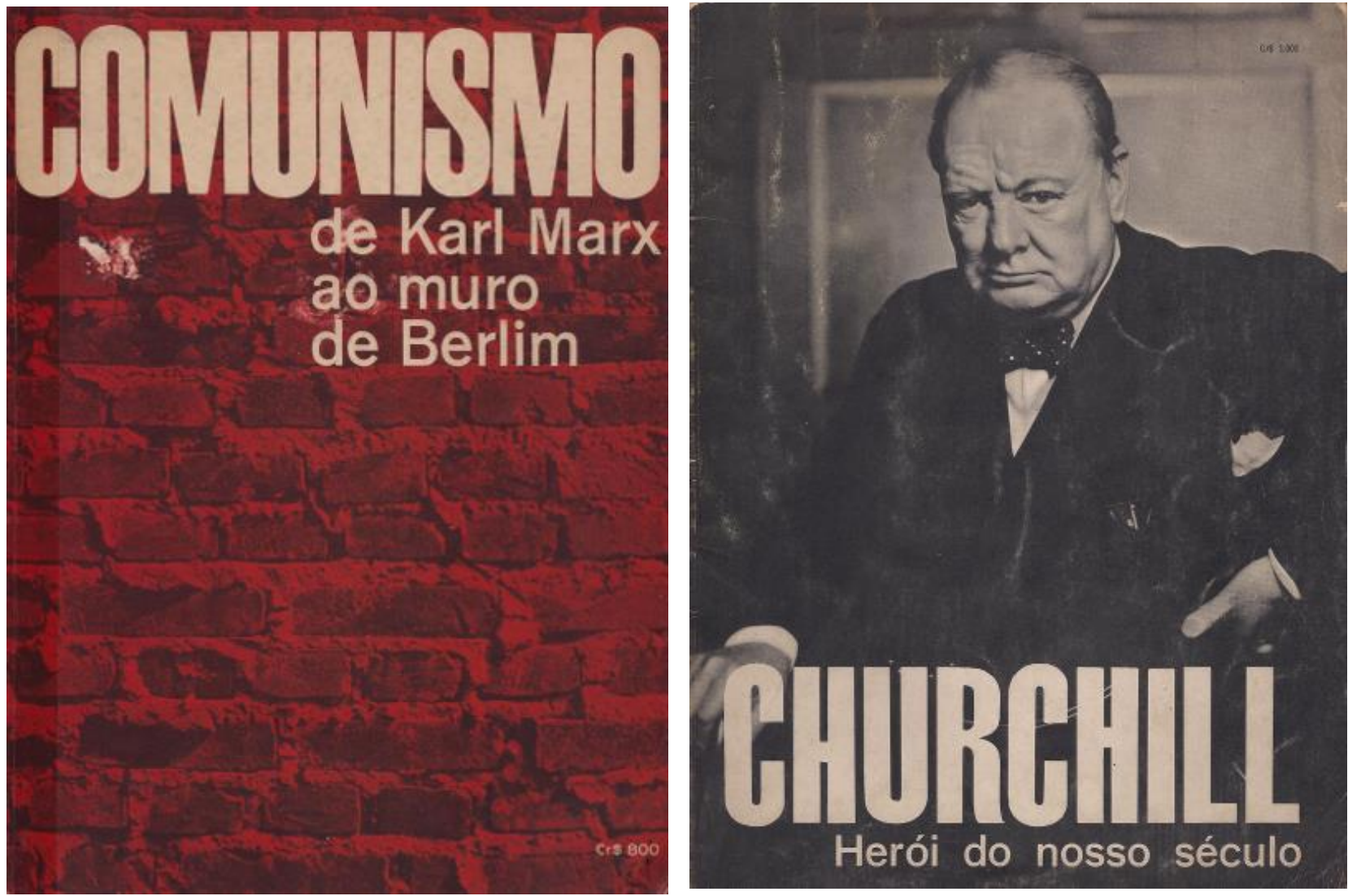

Fonte: acervo pessoal do autor.

Papillon foi impresso pela S.A.I.B. em março e lançado em 23 de abril de 1970. Não foi exatamente uma aposta no escuro, mas uma visão de oportunidade dos editores: a obra original havia sido publicada apenas oito meses antes e vendido mais de 1 milhão de exemplares na França. A decisão de editá-la certamente foi tomada antes de se atingir a marca, mas já com dados seguros de que as aventuras de Carrière eram um best-seller que há muito não se via. O processo de planejamento, tradução, edição e impressão ocorreu em um curto espaço de tempo, estratégia oportuna da Editora para colocar o livro nas bancas quando a versão francesa ainda estava em evidência e acumulando grande vendagem.

No dia anterior ao lançamento em bancas, Veja (A FUGA...,1970) apresentou uma entrevista de quatro páginas sobre a história de Henri Carrière: de sua condenação na França a partir de um suposto erro do judiciário; a transferência para prisões na Guiana Francesa; a fuga cinematográfica após diversas tentativas e o asilo na Venezuela. Em nota de rodapé, a indicação do livro publicado pela própria editora, com valor de venda indicado, embora ainda não estivesse disponível. A 
revista Realidade, em sua edição de abril de 1970, trouxe também em suas páginas um capítulo como amostra da então inédita publicação. Tratava-se do quarto capítulo ("A reclusão"), em que se narra o período em que Papillon ficou preso em uma cela solitária por dois anos devido a uma tentativa de fuga anterior. Ao final, a indicação de que "o livro completo estará à venda no fim do mês" (ELE..., 1970, p.78) ${ }^{19}$.

Conforme Roberto Civita (CIVITA, 1975), Papillon foi um experimento que deu segurança de que seria possível lançar livros em massa através de bancas de jornais. O romance teve impressos, inicialmente, 50 mil exemplares, sendo que 20 mil foram vendidos nas primeiras seis semanas, com base nas propagandas veiculadas pela própria editora. Há referências que indicam terem sido de 15 dias o período em que se esgotou a primeira tiragem (CLEMENTE, 1980), mas parece ser uma conta demasiado otimista, tendo como base as informações divulgadas pela publicidade da própria Editora.

O número de unidades comercializadas de Papillon não é muito claro e, na época, houve questionamentos sobre um possível fracasso nas vendas. Em 18 de junho de 1970, há uma nota no diário carioca Correio da Manhã (LIVROS..., 1970) onde Pedro Paulo Poppovic, diretor da divisão de fascículos da Abril, desmente a informação de que Papillon teria um volume de vendas aquém das expectativas, reafirmando que já havia vendido 20 mil exemplares, em consonância ao discurso das propagandas. Há de se pensar em duas hipóteses no caso: 1) ocorreu, de fato, um fiasco de vendas, e a informação já circulava entre os setores da imprensa (provavelmente pela antecipação por parte de jornaleiros). A editora, procurando reverter a situação, inicia a publicação das peças e remete a nota ao jornal, através de Poppovic; 2) as vendas foram de acordo com o esperado ou acima da meta; porém, com a possibilidade de não ter conseguido alcançar bom volume no Rio de Janeiro ou em outras praças, procurou-se fomentar a circulação nestes locais através de propagandas que remetessem às vendas gerais.

Outro ponto polêmico em Papillon foi a ausência de designação do tradutor da obra, o que foi indicado em algumas notas de lançamento e resenhas sobre o livro.

19 A utilização da máquina publicitária da Abril entre as revistas da própria editora e outros canais será tema do capítulo subsequente. Neste momento, o enfoque será na produção editorial das edições. 
Nesse sentido, Zózimo Barroso do Amaral (AMARAL, 1970, p. 3), em coluna no Caderno B do Jornal do Brasil, datado de 23 de abril de 1970, comenta que o suspense em Papillon não é causado pelas aventuras do personagem principal, mas pelo mistério de quem seria o tradutor da obra. No dia seguinte, Ediberto Coutinho (COUTINHO, 1970, p. 6) produz uma resenha na coluna de livros do Correio da Manhã em que não deixa de apontar a omissão do tradutor, que classifica como "estranha”. No mesmo Correio da Manhã (LIVROS..., 1970, p. 7), houve, no dia 16 de maio, o levantamento da hipótese de que o tradutor poderia ser crítico literário Léo Gilson Ribeiro, de Veja. Já a revista Realidade (PAPILLON..., 1970, p. 12), na edição de número 50, de maio de 1970, apontou que Leandro Konder foi o responsável por coordenar a tradução de Papillon, sem, no entanto, informar quem de fato realizou o trabalho.

Papillon teria muitas outras edições publicadas no país, desde seu lançamento pela Abril. Em 1973, a Difusão Europeia do Livro (Difel) relançou a obra, com a mesma capa e formato da edição publicada pelos Civita. O romance autobiográfico de Carrière foi reeditado em diferentes ocasiões pela própria Abril: apareceu, mais de uma vez, como integrante do Círculo do Livro; fez parte do catálogo da Edibolso, em formato de bolso (1976), e da coleção "Grandes Sucessos", em 1982. Nenhuma das edições de Papillon publicada no Brasil durante a década de 1970 a que tivemos acesso apontavam o nome do tradutor, mas as edições realizadas pela Bertrand, em Lisboa, identificavam Mário Varela Soares como o responsável pelo trabalho. A colação entre o texto publicado em Portugal, na "Coleção Autores Universais", e os publicados no Brasil não deixa dúvidas: todas as edições em língua portuguesa, inclusive a da Abril, apresentam a tradução de Soares. É provável, neste caso, que a Abril tenha adquirido os direitos para publicação de Papillon em língua portuguesa e adaptado a linguagem para o português brasileiro, trabalho este, talvez, executado por Léo Gilson Ribeiro, Leandro Konder ou algum funcionário da Abril Cultural. Não é possível averiguar, no entanto, os motivos que levaram a Editora a omitir o nome do tradutor, nem da editora detentora dos direitos sobre a versão em português.

Por fim, nota-se que, ao contrário da edição original francesa, as nacionais setentistas não incluem a introdução de Jean-Paul Castelnau, responsável por apresentar Carrière à editora Robert Laffont, que publicou a versão original na 
França, nem o ensaio "Papillon ou A Literatura Oral (Papillon ou La Littérature Orale)", de Jean-François Revel. A edição publicada pela Bertrand conta com a apresentação de Castelnau, mas não com o ensaio de Revel.

O sucesso de Papillon é parte de um processo que foi precedido por outras publicações culturais da Abril. O interesse neste tipo de produto editorial está vinculado à constituição econômica e social que se apresentou após 1964, em que a mobilidade social de parte dos trabalhadores fez surgir uma nova configuração da classe média brasileira, que buscava, naquele momento, instrumentos culturais e educacionais para ascender e estabelecer-se em seu novo espaço econômico e social; bem como ansiava por ferramentas de distinção de classe. É importante, portanto, refletir sobre o panorama em que as edições de livros da Editora Abril foram lançadas para compreender a dinâmica de produção e circulação das obras na década de 1970 .

\subsection{A euforia econômica faz surgir o público: educação como meio de ascensão}

Quando Papillon apareceu nas bancas de jornais, haviam se passado cinco meses desde que o Brasil ganhara o tricampeonato mundial de futebol, com uma goleada sobre a Itália na final e uma seleção que encantou o mundo. O "milagre econômico" estava em seu auge e proliferavam as ofertas de bens de consumo, que se tornaram itens de desejo nas grandes cidades. Emilio Garrastazu Médici, o general que vibrava com os jogos da seleção e recepcionara pessoalmente os campeões no aeroporto, havia sido eleito de maneira ilegal após uma "revisão constitucional”, ou seja, claro desrespeito à Constituição estabelecida, algo comum durante o regime civil-militar pós-1964.

A ascensão de Médici tem origem pouco mais de seis meses depois de decretado o Ato Institucional nro. 5 (A.I.5), que, em 13 de dezembro de 1968, autorizou uma série de medidas de exceção que resultaram, entre outras, na cassação de mandatos eletivos; intervenções em Estados e Municípios; cassação de direitos políticos; demissão, remoção ou aposentadoria compulsória de funcionários públicos; confisco de bens; e suspensão do direito ao habeas corpus para crimes 
políticos ou contra a segurança nacional. Em setembro de 1969, o presidente em exercício, Arthur da Costa e Silva, foi afastado do governo devido a problemas de saúde. Em seu lugar, assumiu, ao invés do civil Pedro Aleixo, então vice-presidente, como estava previsto na Constituição, uma junta militar que governou o país até o fim do mandato de Costa e Silva. Em 25 de outubro de 1969, Médici foi eleito indiretamente pelo Congresso Nacional.

Sua gestão foi marcada pelo profundo contraste entre crescimento econômico acelerado e aumento da repressão, sob a forma de censura; perseguições; torturas e desaparecimentos. A inflação foi controlada, os índices de alfabetização e acesso ao ensino superior se elevaram, mas a desigualdade social disparou. No âmbito econômico, o governo conseguiu aumentar a arrecadação, especialmente através do imposto de renda, que cresceu $60 \%$ em termos reais, em 1969, potencializando a capacidade de investimento. A política de créditos permitiu à indústria, em especial a indústria automobilística, desenvolver-se e crescer substancialmente nos governos militares. Conforme Skidmore (1988), as exportações elevaram-se 126\% entre 1970 e 1973, devido aos incentivos tributários e creditícios do governo, o que gerou uma balança de pagamentos favorável. A entrada de capital internacional, através de empréstimos e investimentos, também foi significativa no período e a intensa industrialização do país demandou grande quantidade de bens de capital e insumos importados. Assim, a despeito do intenso volume de exportações, o Brasil tornou-se dependente do capital internacional e a dívida externa subiu sensivelmente a partir de 1968, ano em que se inicia a expansão econômica do "milagre".

A intensa industrialização do país, concentrada nos centros urbanos, expandiu a oferta de emprego nas grandes cidades, embora a perseguição a sindicatos e seus líderes tenha ocasionado o arrocho salarial dos trabalhadores de baixa escolaridade. Houve, apesar disso, ganhos reais de remuneração para algumas categorias, especialmente a de profissionais especializados, com maior grau de instrução. A conjunção entre o arrocho salarial do proletariado e o incremento na renda de profissionais especializados foi responsável por elevar a desigualdade social no país. O número de trabalhadores empregados nas indústrias em geral (extrativa e de transformação) cresceu durante praticamente toda a década de 1970, regredindo apenas nos anos 1980, conforme se pode observar na Tabela 1. Assim, ainda que, de uma maneira geral, o rendimento fosse insuficiente e o custo de uma melhor 
condição de vida muitas vezes estivesse relacionado a múltiplas jornadas de trabalho e ao aumento de membros da família empregados, elevou-se o padrão de vida e o acesso a bens de consumo por parte da população, principalmente na faixa formada pelos habitantes das regiões economicamente centrais (Sul e Sudeste).

Tabela 1 - Pessoal ocupado ligado à produção (Indústria Geral)

\begin{tabular}{|c|c|}
\hline Período & Contingente \\
\hline 1970 & 2.154 .146 \\
\hline 1972 & 2.050 .001 \\
\hline 1973 & 2.689 .446 \\
\hline 1974 & 2.803 .064 \\
\hline 1975 & 3.122 .014 \\
\hline 1976 & 3.273 .774 \\
\hline 1977 & 3.410 .604 \\
\hline 1979 & 3.786 .063 \\
\hline 1980 & 4.073 .753 \\
\hline 1981 & 3.656 .731 \\
\hline 1982 & 3.738 .236 \\
\hline
\end{tabular}

Fonte: Estatísticas do século XX. Rio de Janeiro: IBGE, 2007.

Sob esse cenário, as classes intermediárias, constituídas, em grande parte, por profissionais liberais e o proletariado urbano superior (trabalhadores especializados e de quadros técnicos) conquistaram bens duráveis que se tornaram símbolo de posicionamento social naquele período, como a geladeira, a televisão a cores e o carro próprio. A partir de 1968, o número desses bens vendidos no país tem acentuado aumento, em decorrência das políticas de incentivo ao setor industrial implementadas por Costa e Silva, como a reestruturação da carga tributária para a indústria, oferta de crédito ao consumidor e facilidade para a exportação (SKIDMORE, 1988), medidas que viriam se somar ao reformulado Código Tributário Nacional, implementado em 1966, que havia introduzido o IPI (Imposto sobre Produtos Industrializados) e o ICM (Imposto sobre Circulação de Mercadorias) como tributos simplificadores e redutores da carga fiscal sobre o consumo. 
O incentivo ao consumo, seja através da oferta de crédito aos consumidores ou de auxílios fiscais aos empresários, produziu efeitos benéficos ao governo em dois âmbitos: a percepção de melhora na qualidade de vida por parte da população, através de acesso a diversos bens; e o incremento à atividade industrial e, por consequência, ao sistema econômico como um todo. Em 1975, apenas três anos depois de introduzida no país, a televisão a cores vendeu mais de quinhentas mil unidades e, no mesmo ano, 1029000 refrigeradores foram comercializados $^{20}$.

A partir do cenário de crescimento acelerado, amplificou-se o discurso ufanista de "Brasil Potência" e "país do futuro", fenômeno investigado por Carlos Fico (1997), que demonstrou ter se originado o conceito séculos antes dos governos militares pós-1964, mas recuperado e adotado pelos chefes militares pós-1964. A noção de "ilustração das massas" frutificou e enraizou-se nas classes médias desejosas de participarem do projeto de um país em desenvolvimento que almejava tornar-se potência e mostrou-se útil à propaganda que procurava associar o hábito da leitura e a instrução formal ao conceito de ascensão social. Se o acesso a bens de consumo estava suprido nas classes intermediárias da sociedade, havia, no entanto, a necessidade de algo, ao mesmo tempo, subjetivo e objetivo: o conhecimento.

No que tange à materialização do conhecimento, sob a visão da nova classe média, transformada em público consumidor, o livro era um elemento fundamental e que deveria estar presente nas prateleiras das casas, já que, para as famílias, possui-los era oferecer aos filhos em idade escolar instrumentos para incremento na educação, que se refletiria em mais oportunidades de trabalho e possibilidade de ingresso no ensino superior. Em caráter subjetivo, os livros, em especial aqueles de capa dura, com letras gravadas em dourado junto a belos arabescos e ornamentos, simbolizavam que seus proprietários eram pessoas ilustradas, com acesso ao saber erudito, já que detinham um objeto antes exclusivo às elites. O livro é um recurso eficaz no processo de distinção e investir em obras de luxo era primordial para o posicionamento de uma faixa da população que havia se deslocado de classes mais baixas e que precisava de elementos distintivos para a afirmação do novo estado social.

20 Segundo dados da Associação Brasileira da Indústria Elétrica e Eletrônica, Dados Estatísticos do Setor (Abinee), colhidos em www.ipeadata.gov.br. 
A Bíblia Mais Bela do Mundo foi direcionada a esse público e a Abril soube utilizar, na propaganda, estratégias de convencimento que mobilizaram a compra em massa do primeiro fascículo. Ter em casa uma Bíblia ilustrada, em grande formato e capa dura, com um texto atrativo e compreensível, pelo investimento de apenas alguns cruzeiros por semana, tornou-se uma oferta irresistível. As coleções que se seguiram durante a década de 1960 adotaram as mesmas estratégias, alternando apenas o perfil do consumidor a que se destinavam, com destaque para crianças e jovens em idade escolar, donas de casa desejosas em melhorar seus dotes em culinária e corte e costura e interessados em conhecer a música clássica/erudita.

Em novembro de 1970, quando Imortais da Literatura Universal, a primeira coleção de livros completos é lançada, a Abril contava com dois elementos a seu favor: 1) acreditava a Editora que existia um perfil de consumidor que pudesse estar interessado em obras prontas, cuja coleção produzisse uma pequena biblioteca pessoal, e não apenas uma enciclopédia em vários volumes, como resultavam os fascículos até então; 2) passados cinco anos da primeira experiência com o formato dos fascículos no Brasil, o público já havia adquirido o hábito de colecionar publicações culturais vendidas em capítulos nas bancas de jornal. O modelo de fascículos e o desejo pela formação de coleções pessoais foram bases sólidas do sucesso editorial das publicações culturais da Abril.

A editora adotou o formato dos fascículos e neles investiu para a produção de quase todas as suas coleções e, em geral, apenas livros publicados fora de séries colecionáveis não acompanhavam fascículos. De fato, no que tange às coleções de livros já encadernados, os fascículos eram acessórios do produto principal, e seu valor revelava-se como ferramenta de introdução às obras e mediadoras do processo de apropriação dos textos, além da possibilidade, muito bem trabalhada pelas peças publicitárias, de se formar obras de referência através da encadernação dos livretos durante ou ao final das coleções.

Ainda que os fascículos fossem complementos, atingiram, ao longo dos anos, tal importância e valor na cultura de massas brasileira a ponto de serem promovidos, pela Abril, como uma forma diferente de se vender livros. $O$ enfoque das peças publicitárias e do discurso editorial, inicialmente, apresentou-se no sentido de que se deveria adquirir os fascículos para, por sua vez, ganhar o livro. Assim, comprava-se 
o fascículo e recebia-se, como brinde, o livro. Roberto Civita (1975) defendeu, em uma palestra realizada em 1975, que a Editora iniciou a venda de livros em bancas em 1965, com o lançamento da Bíblia. Para ele, os fascículos eram livros vendidos em capítulos semanais, sendo considerados não um outro formato, mas uma forma diferente de comercializá-los.

O objetivo deste trabalho, no entanto, é a análise dos livros prontos e encadernados, já em seu formato final, como aqueles que poderiam ser adquiridos em qualquer livraria convencional, diferente da perspectiva generalista de Civita e da Abril. Neste modelo alternativo de produção e circulação dos livros, fora do espaço institucionalizado da livraria, a Editora foi bem-sucedida em oferecer obras inacessíveis, seja por impedimentos econômicos, culturais ou de distribuição, a uma parcela da população brasileira sem hábito de comprar, colecionar e ler livros de literatura, filosofia, teatro, entre outros diversos temas em que lançou luz com edições populares vendidas em bancas durante os anos 1970.

Entre os livros encadernados que a Abril editou, Os Imortais da Literatura Universal foi a primeira coleção a chegar às bancas de jornais, em novembro de 1970, apenas seis meses após a publicação de Papillon. O projeto foi um marco na edição e distribuição de obras clássicas no país e iniciou a série de publicação de coleções de livros que consagrariam a editora durante a década de 1970 no campo editorial. O lançamento de um empreendimento desse porte só foi possível porque já existia um público habituado a comprar em bancas produtos culturais colecionáveis, hábito esse criado pelos fascículos. Por isso, ainda que nosso objeto principal sejam os livros, os fascículos comporão algumas análises em determinados momentos da pesquisa. Considerando que os fascículos foram responsáveis por desenvolver, ao menos no que tange às edições da Abril, o hábito de se colecionar produtos culturais vendidos em bancas de jornais, convém, neste momento, avaliar esta questão, especificamente: a coleção e o colecionismo. Não a coleção sob a perspectiva institucional, de formação de acervos, mas pela ótica do colecionador particular, amador, em seu sentido etimológico primeiro, o daquele que ama, reunindo determinados itens buscando completar uma série ou coletar todo o possível sobre determinado tema. 


\subsection{A coleção}

O homem sempre foi um ser colecionador. Desde a Antiguidade, nos rituais funerários na Anatólia e China ou oferendas aos deuses na Grécia; nas coleções de objetos adquiridos ou saqueados por reis e imperadores, como o romano Nero, ou nas relíquias religiosas orientais e ocidentais, a necessidade de reunir objetos esteve presente e evoluiu junto ao próprio desenvolvimento das sociedades no tempo e no espaço, conforme demonstrou Krzysztof Pomian (1984). Coleções modificaram sua composição, essência e finalidade ao longo da História, mas mantêm, através dos objetos, seu caráter de mediadoras entre o visível e o invisível, o que está em nosso tempo e espaço e o que deles se distancia (ou ainda o que não se inscreve no espaço físico ou encontra-se num tempo sui generis).

Se uma coleção de livros é posta em estantes, apenas para contemplação ou como objeto de decoração do ambiente, perde seu valor utilitário como meio de transmissão de informações, mas não deixa de ter função. Sob o ponto de vista do valor da coleção contemplativa, Pomian (1984, p. 54) constata que, embora percam seu valor de uso, os objetos retirados de circulação ainda possuem valor de troca. Este valor origina-se do instinto presente em alguns indivíduos que os predispõem à propriedade ou propensão de acumular certos objetos, cuja posse confere prestígio, testemunhando "o gosto de quem as adquiriu, ou as suas profundas curiosidades intelectuais, ou ainda a sua riqueza ou generosidade, ou todas estas qualidades conjuntamente".

Walter Benjamin (1987, p. 215-223), que além de um renomado pensador e ensaísta foi um colecionador aos moldes clássicos, com paixão pelas obras raras e únicas, expôs suas ideias sobre "o relacionamento do colecionador com seus pertences". Para ele, no entanto, a coleção de livros antigos, raros, está mais próxima da "fonte do colecionador" que a de "novas edições luxuosas". As experiências na aquisição constituem papel fundamental na formação de uma coleção e Benjamin alterna entre livrarias e leilões para rememorar a origem dos itens de seu acervo, cujo traço mais distintivo é a transmissibilidade. A herança é um fator importante na formação de coleções. Seja de um familiar, instituição pública ou privada, o colecionador deseja que sua obra, a coleção, possa, além de representarIhe, sobreviver a si mesmo. Benjamin refere-se a um tipo particular de colecionador, a quem exalta e define como autêntico por fazer parte do círculo de colecionadores 
eruditos, mas o caráter geral de suas análises - o sentimento da posse, a transmissibilidade, a caracterização do proprietário no conjunto de seus livros - pode ser associado também aos colecionadores de obras comuns, como as da Abril.

Tratando de paixões como as coleções despertavam em Benjamin, Basbanes (1995) realiza um interessante e completo percurso histórico sobre a bibliofilia e a bibliomania, por ele denominadas de gentle madness (dócil loucura, em tradução livre), embora, como demonstram as histórias dos vários personagens abordadas no estudo, o furor colecionista que leva as pessoas a dispenderem fortunas, a roubar e até a matar para terem um item especial em sua coleção não seja tão gentil ou dócil como sugere o termo. A coleção, a depender do colecionador, pode flutuar entre a gentileza e a loucura, mais frequentemente caracterizando-se pela segunda.

Embora tenham características em comum, de certa maneira dotadas de uma mesma essência, as coleções podem distinguir-se pelos espaços sociais que os indivíduos ocupam. Este espaço, hierarquizado, define-se pelos tipos de objetos que se coleta e pelos que são coletados. A coleção feita por pessoas de classes mais baixas no interior do país é diferente daquela feita por membros da elite nas capitais. Ainda que os interesses em determinados objetos se coadunem, são peculiares a maneira como se opera o modelo da coleção, a capacidade financeira de se reunir peças, a forma como são expostas e o vínculo entre as peças e o colecionador.

Faria e Pericão, em seu Dicionário do Livro (2008, p. 175), definem “coleção”, no âmbito em que se incluem as editadas pela Abril, como "grupo de publicações distintas, ligadas entre si por um título em comum, cada uma com o seu título próprio e seu responsável, expresso ou não". Ainda, a coleção possui “[...] o seu responsável, singular ou coletivo, pode ser ou não numerada [...]", seguindo, "[...] em geral, a regras editoriais que regem o formato, a capa, as ilustrações, o númeo [sic] de pesquisas, a impressão de um conjunto de textos sobre temas considerados homogêneos pelo editor". Nas análises a serem efetuadas, será possível observar a padronização de elementos como capa e formato dos livros, além da ilustração e composição dos textos, sempre dotados de um título geral para a série e específicos para cada exemplar. Embora se busque uniformidade para o contexto de uma coleção, há desvios que ocorrem devido a erros gráfico-editoriais, mas que não anulam a tentativa de se obter um conjunto padronizado para as obras. 
Sob o ponto de vista antropológico, o estudo de José Rogério Lopes demonstra o caráter intrínseco entre a biografia do colecionador, o enfoque e o modelo de sua coleção, inclusive entre a escolha de expô-la ou não, e a maneira como é feita a exposição. Para o autor,

\begin{abstract}
é importante enfatizar que essas práticas devem ser pensadas em razão da biografia das pessoas, no sentido de que o momento em que se começa a colecionar e os motivos das coleções têm relação com a trajetória de vida das pessoas, e marcam propriedades atribuídas a seus ciclos de vida. $E$ embora se trate de um aspecto sempre subjetivo, a relação que as coleções estabelecem com a vida das pessoas é um motivo interessante para pensar, para pesquisar e, ao mesmo tempo, para compreender a forma pela qual as coleções depois são expostas, ou não, e em que condições, ou atendendo a que intencionalidades (LOPES, 2010, p. 386).
\end{abstract}

A relação entre os ciclos da vida, a biografia e a trajetória pessoal, permite compreender a influência do cenário político, econômico e social dos anos 1970 sobre a população, considerando-se as grandes mudanças no país e seus reflexos nos hábitos das pessoas em determinados estratos sociais. Esses fatores são significantes para a constituição do hábito de se colecionar produtos culturais como os editados pela Abril. O panorama da década de 1970 foi importante agente na caracterização do desejo, dos objetos e dos objetivos de uma parcela da população que, em outro cenário, dificilmente teria condições e entusiasmo pela compra, coleta e exposição de livros de temas considerados eruditos, sob o ponto de vista de sua legitimação pela crítica especializada.

O público da Abril inscreve-se em um grupo muito particular de colecionadores de livros: não são exatamente aficionados, nem especialistas em um determinado tema, do qual, delimitado, pretende-se coletar tudo que for possível em seu melhor estado (que seria o mais próximo à originalidade, não sob o ponto de vista apenas do objeto único, mas também da conservação de suas características). Não tendo recebido como herança o conhecimento que julgavam encontrar nas obras, conectavam-se com o invisível, na definição de Pomian (1984), ao adquirir as coleções. Invisível constituído pelo desejo de um melhor posicionamento econômico social, uma virtualidade que almejavam e só poderia se atualizar, em sua visão, pela mediação de determinados instrumentos, entre os quais, os livros.

O colecionismo, movimento que enseja paixões, sejam as eruditas ou aquelas dos simples objetos de uso comum, como coleções populares de chaveiros, tampinhas de garrafa, latinhas de refrigerante ou cerveja - ainda que estas, a 
depender do colecionador, possam ganhar ares de alta erudição - é um agente mobilizador importante para o consumo de objetos industrializados. Conforme Baudrillard (2009, p. 93-114), o objeto, abstraído de sua função utilitária, reflete a individualidade do sujeito em sua posse. Assim, a propriedade privada de um objeto constitui o arcabouço de sentidos e provê identidade a quem o possui. Para o autor, entretanto, o objeto só se realiza para o sujeito a partir da coleção, "a organização mais ou menos complexa de objetos que se relacionam uns com os outros [e] constitui cada objeto em uma abstração suficiente para que possa ser recuperado pelo indivíduo na abstração vivida que é o sentimento da posse".

O objeto desligado de função utilitária readquire sentido a partir de uma perspectiva relacional, quando está vinculado à coleção, e o valor que se dá às ausências, às peças faltantes, é diretamente proporcional à dificuldade em se obtêlas. A partir dessa premissa, formar a coleção é prover significados aos objetos, mas também às lacunas, aos hiatos, aos espaços vazios que a compõem. A somatória dos significados dos itens (e das faltas) produz o sentido do todo, que é a coleção. Instaura-se, daí, a necessidade de obtenção das partes para dar forma ao conjunto, à série: quando se possui um item, é preciso comprar o posterior; caso não se tenha o anterior e nem haja possibilidade de obtê-lo, talvez não valha a pena adquirir o atual, nem o próximo, uma vez que encerra-se a perspectiva de significar a coleção ao completá-la. Apartado do todo, o objeto colecionável, já abstraído de sua utilidade, deixa de ter qualquer valor. O conceito simbólico da coleção completa dá origem, portanto, ao mecanismo psicológico que rege o hábito de se acumular itens em série, até que se possa satisfazer o sentido, louco ou gentil, do conjunto integral e organizado.

Esse pressuposto é fundamental para a compreensão do volume de vendas que atingem os livros da Abril: após a compra do primeiro exemplar, uma parte dos que a fizeram por mero impulso, seja por influência da propaganda, curiosidade, gosto ou indicação, não voltava a comprar os próximos números ou comprava apenas alguns, esparsos, sem chegar a completar a coleção de fato. Entretanto, aqueles que adquiriram o hábito de colecionar seguiram comprando cada exemplar publicado, ainda que o processo demorasse mais de dois anos, em alguns casos. É o que explica a curva de vendas que se estabilizava a partir de um percentual da comercialização do volume inicial, conforme apresentado no capítulo anterior. A 
casuística do objeto faltante, junto à complexidade cultural, de acordo com Baudrillard (2009, p. 93-114), define a série como elemento constituinte de toda coleção, diferenciando-a da mera acumulação. E o item faltante é responsável por substituir o interesse real pelo formal, "uma pura coação associativa que atua na motivação da compra”.

A editora Abril, consciente desta dinâmica, investiu na formação do hábito de se colecionar entre seu público, porque reconhecia a importância desta prática para a viabilidade de um projeto. Se, inicialmente, havia um motivo real para a compra, após o início e habituação na aquisição e coleção dos livros, o interesse era suplementado pela formalidade do ato de completar a coleção. Esse fenômeno assegurava que o fluxo de vendas seria suficiente para a viabilidade do negócio.

A função semiológica e psicológica do colecionismo para a edição de livros em série vendidos em banca é fundamental, e, ao menos nos primeiros anos após o início da atividade de vendas de fascículos culturais, a Editora procurou investir também na comercialização de acessórios complementares às coleções e que desenvolvessem o hábito de se armazenar os exemplares. A ideia de comercializar mobiliário para a guarda e exposição das coleções surgiu em 1968. Em parceria com a empresa Mobília Contemporânea, do designer francês radicado no Brasil Michel Arnoult, a Abril lançou uma estante compacta (Fig. Figura 12 e 13) (83 cm de altura X $85 \mathrm{~cm}$ de largura $X 31 \mathrm{~cm}$ de profundidade), desenhada para a conservação e apresentação de fascículos encadernados, resistente (estrutura em imbuia maciça com laterais em jacarandá), com prateleiras ajustáveis, de fácil montagem (sem a necessidade de pregos ou parafusos) e modulável, podendo ser expandida vertical e horizontalmente através da compra de outras unidades. 
Figura 12 - Estante projetada pela Mobília Contemporânea para as coleções da Abril Cultural

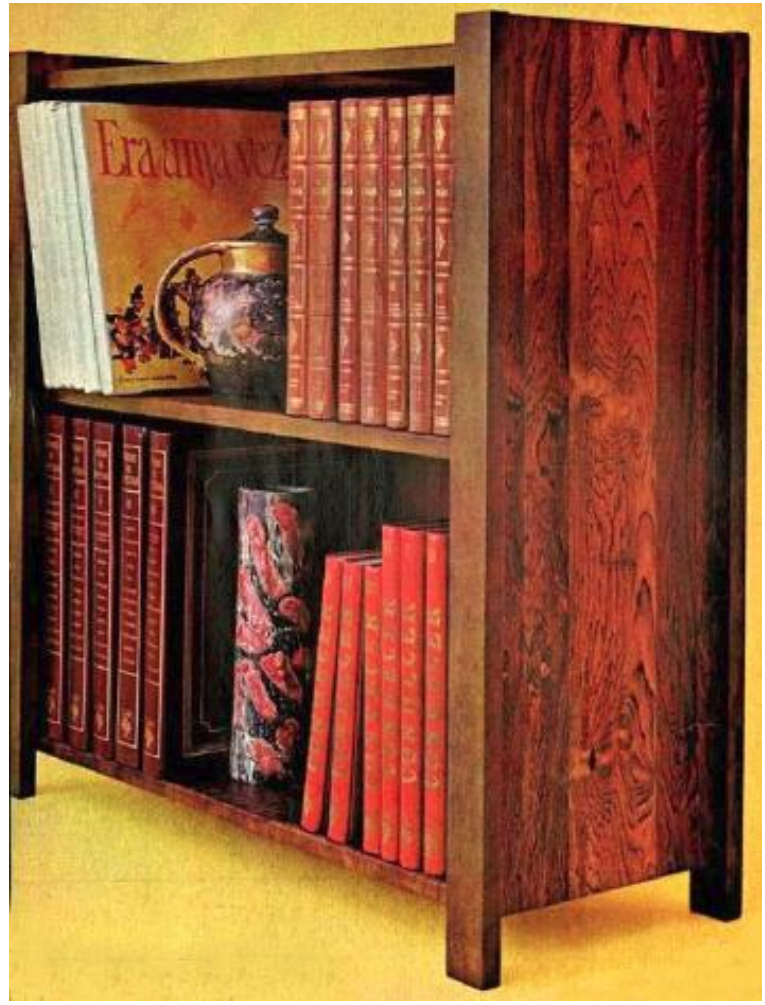

Fonte: Revista Veja (1968a, p. 72).

Figura 13 - Estante projetada pela Mobília Contemporânea para as coleções da Abril Cultural ambientada em uma sala

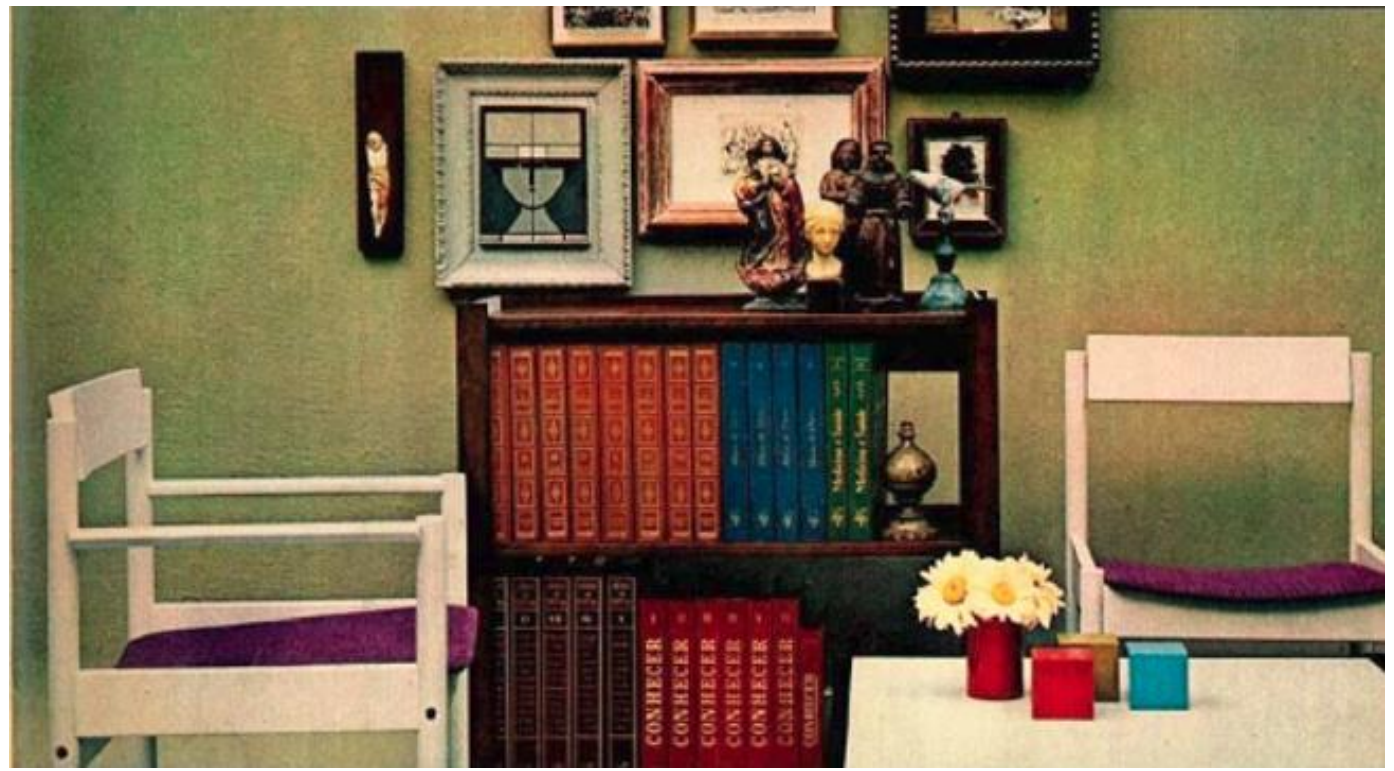

Fonte: Revista Veja (1968b, p. 11). 
Este mobiliário, além do incremento à receita da Abril pela diversificação de negócios e aproveitamento de projetos em áreas diversas, modelo que a Editora utilizaria nos anos seguintes, era, pelo seu baixo custo (Cr\$96 em seu lançamento), um incentivo à exibição e ampliação das coleções, além de funcionar como objeto de decoração para sala de estar ou ambientes compartilhados nas residências. A exposição da coleção era tão importante quanto seu conteúdo.

No editorial de Veja de 08 de outubro de 1969, Mino Carta (CARTA, 1969), então editor da revista, comenta a carta recebida de dona Martha Pinheiro Monteiro, de São Paulo. Nela, a leitora relata o caso de um exemplar da revista, que vinha acompanhado de um fascículo sobre a chegada do Homem à Lua, perdido, aparentemente, em uma faxina. O marido da leitora comprava os fascículos "na banca de costume" mas, depois de lido, o exemplar em questão desapareceu. Dona Martha pretendia encadernar o fascículo junto aos outros da mesma série, para "por o livro na estante da sala". A situação do número perdido se agravou quando a filha, de dezesseis anos, chegou da escola com a tarefa de realizar um trabalho sobre a conquista da Lua, com indicação do professor de "consultar o livro de Veja". O marido de dona Martha procurou, em vão, uma banca de jornais que ainda pudesse comercializar a revista com o fascículo faltante. O caso apenas se resolveu quando a carta foi enviada à redação de Veja, que disponibilizou o número e a filha pôde tirar "uma nota digna das esperanças familiares e o livro de Veja ganhou um merecido lugar na estante da sala".

Este prosaico relato é um retrato dos apontamentos realizados até agora: 1) o colecionismo (na figura do pai que comprava os números na banca habitual); 2) a substituição do interesse real pelo formal (o pai talvez não comprasse todos os números de Veja pelo simples interesse no conteúdo, mas pela possibilidade de colecionar os fascículos que acompanhavam os exemplares e encaderná-los formando um belo volume); 3) a instrumentalidade do livro (enquanto detentor das informações necessárias para o trabalho escolar); 4) o contato com o invisível (na esperança de que o livro mediasse o desempenho da filha, que era a "esperança familiar" de um melhor futuro para o casal); e 5) a distinção através do livro como símbolo de objeto de classe (após ganhar o merecido lugar na estante da sala).

Expostos os conceitos sobre coleção e colecionismo, serão analisadas, agora, as três coleções de livros que foram selecionadas para este estudo por sua 
relevância, sob o ponto de vista da inovação na temática, ineditismo editorial, sucesso comercial. O enfoque será no texto e nas características materiais, especialmente a questão formal, por ser um elemento fundamental para sua aceitação pelo público, a partir do contexto em que foram publicados; e também devido às estruturas materiais guardarem em si, além dos vestígios do tempo, pistas e indícios valiosos sobre o processo de sua produção editorial.

\subsection{Uma coleção imortal}

A coleção "Imortais da Literatura Universal" foi um produto singular à época de seu lançamento, percorrendo a contramão de tudo o que se convencionava comercializar em bancas de jornais até então, tornando-se um marco na história editorial brasileira. Em 1969, a publicação de obras de literatura no Brasil foi de apenas 5,72\% do total de livros publicados naquele ano (68 068 200) (HALLEWELL, 2005, p. 561). A experiência realizada com Papillon demonstrou que era viável o comércio de livros em bancas e os editores da Abril, após o sucesso do romance de Carrière, convenceram-se de que seria possível, e ideal, de fato, ir além: ao invés de optarem por uma coleção de romances contemporâneos de sucesso, preferiram realizar um empreendimento ainda mais audacioso, com a seleção de obras literárias que "dessem um panorama global da evolução literária do século XIV ao século XX" (IMORTAIS, 1970, p. 68).

O responsável por dirigir a coleção foi Ary Coelho, tendo como vice-diretores editoriais, em diferentes momentos da coleção, Manuel Carlos Vieira (nro. 1 - 16), Elzira Arantes (17 - 34) e José Américo Mota Pessanha (34 - 50). O prof. Ângelo Ricci prestou assessoria ao projeto e, com o apoio de professores-consultores, realizou uma pré-seleção de 450 autores, entre novelistas e romancistas, dentre os quais foram definidas 50 obras (Anexo I). Apesar do título, a coleção esteve longe de alcançar um caráter "universal", ao menos geograficamente, devido à limitação de sua abrangência. Houve uma concentração de exemplares dedicados a autores europeus $(86 \%)$ e o restante dos volumes incluíram autores do continente Americano (14\%) - incluídos América Latina e do Norte. A milenar literatura oriental foi ignorada e o mais próximo que a coleção chegou da parte leste do planeta foi na edição dos 
russos Dostoiévski, Turguêniev, Tolstoi e Gógol, assim como não houve nenhum autor africano ${ }^{21}$ ou da Oceania entre o elenco "universal" dos Imortais.

Os editores consideraram que somente um brasileiro, Machado de Assis, poderia ser apontado como imortal e apenas dois autores de língua portuguesa estiveram aptos a receber a honraria: o próprio Machado e Eça de Queirós. Entre os lusitanos, Camões e Fernando Pessoa, já consagrados na década de 1970, ficaram de fora, enquanto autores do Reino Unido e da França constituíram a maioria dos selecionados. Da mesma maneira, no que diz respeito aos gêneros literários, a poesia não é contemplada em nenhum dos volumes, que são todos dedicados à prosa, majoritariamente ao romance. Assim, pode-se considerar que os editores adotaram o termo "universal" para a coleção sob o ponto de vista da universalidade literária, não geográfica, a partir de textos que, por terem sido bem-sucedidos, circularam entre diversos países do globo, afastando-se seu caráter nacionalista ao serem introduzidos no circuito de uma literatura mundial.

O fato de o catálogo da coleção ser questionável sob o ponto de vista de seu título e respectiva abrangência, bem como pelas presenças e ausências, é também resultado das escolhas dos proprietários da Editora; um reflexo da visão de mundo deles, todos nascidos no continente europeu, para os quais os termos "universal" e "imortal" estavam intimamente associados à Europa civilizadora. Tal conceito pode ter influenciado a seleção que fizeram os editores dos 50 autores para a coleção, julgando que a literatura europeia fosse mais representativa que as outras, e que, portanto, merecesse mais espaço. Ainda, é válido considerar a forte influência da França sobre o Brasil, já desde o século XIX, nos costumes, na literatura e nas artes da elite nacional, processo reavivado pela importância dos intelectuais franceses nas ciências humanas na década de 1970, bem como a popularidade obtida pelos protestos estudantis de Paris em 1968, motivando a escolha devido ao aquecido mercado para obras francesas.

É oportuno frisar que o conceito de literatura universal é muito anterior ao uso na coleção da Abril. Goëthe, conforme Kestler (2012), utilizou-o já a partir de 1827, através do termo Weltliteratur, que, para o autor de Fausto, indicava a literatura como resultado da intrínseca universalidade do próprio Homem em seus

21 Com a exceção de Camus, mas que constituiu sua carreira e é reconhecido como literato francês. 
sentimentos e pensamentos, que, dessa maneira, poderia ser produzida, apropriada e reelaborada por povos de diferentes partes do planeta. Para Marx e Engels, em seu Manifesto do Partido Comunista, publicado em 1848, Weltliteratur referia-se à circulação de produtos intelectuais nas sociedades capitalistas. Para ambos os casos, a circulação universal só se pode efetuar pela tradução, devido às diferentes línguas e dialetos nos quais as produções artísticas são escritas e foram produzidas.

A tradução, sob a perspectiva da oferta de autores ditos "universais" no Brasil, é uma condição para a apropriação das obras no país. Os textos da coleção Os Imortais da Literatura Universal, quase todos em língua estrangeira, como se observou, tiveram seus direitos majoritariamente adquiridos de publicações anteriores realizadas por outras editoras, nacionais e portuguesas. Feitas com exclusividade, estão as de Moll Flanders, de Daniel Defoe, por Antônio Alves Cury; Almas Mortas, de Nicolai Gógol, por Tatiana Belinky; e Moby Dick ou A Baleia, de Herman Melville, por Péricles Eugênio da Silva Ramos. Uma reportagem de Veja, publicada uma semana após o lançamento de Imortais..., aponta que uma das traduções novas e inéditas seria a de Pantagruel, de Rabelais, embora este título não tenha feito parte dos 50 volumes finais da coleção, nem nunca tenha sido publicado pela Abril Cultural posteriormente.

Entre os destaques no campo da tradução, pode-se apontar a predominância de obras da Editora Globo de Porto Alegre, que possui dez traduções entre os títulos da coleção (20\%). A Editora, que atuou no cenário nacional entre o final dos anos 1920 e 1986, quando foi vendida à Rio Gráfica, valorizava a tradução de qualidade, algo pouco comum no Brasil naquele período; e implementou, a partir do início dos anos 1940, uma equipe de tradutores contratados e com salário fixo, dispondo de uma biblioteca oferecida pela editora com dicionários e enciclopédias, como "a gigantesca Espasa-Calpe, a famosa Britannica, a Italiana e várias alemãs, francesas, inglesas e americanas" (VERISSIMO, 1978, p. 50). A Globo foi pioneira em adotar uma linha editorial voltada a traduções não só de autores franceses, como era costume no Brasil, mas também de autores contemporâneos estadunidenses, alemães, ingleses e italianos (BERTASO, 1993). Aparecem também como detentoras de boa parte dos direitos de tradução dos livros publicados em Os Imortais da Literatura Universal as editoras Civilização Brasileira (8 títulos), Difusão 
Europeia do Livro (5 títulos) e Martins (4 títulos), três grandes casas editoriais e também reconhecidas pelo bom nível de suas traduções.

Os tradutores da Coleção, de um modo geral, são prestigiados e respeitados por seus trabalhos neste campo, e as edições originais em português foram realizadas por editoras bem-conceituadas. Porém, há uma suspeita de fraude na tradução de Decameron, do renascentista italiano Giovanni Boccaccio: feita por Torriere Guimarães e publicada pela Editora Hemus, apresenta semelhança com a de Raul de Polillo, editada inicialmente pela Martins em 1956. Tal semelhança chamou a atenção de Gabriel Perissé em artigo divulgado na Revista Língua Portuguesa (2006), e, também, a de Denise Bottmann (2008).

Em relação ao trabalho de preparação e edição dos textos, assim como o de encadernação das folhas, se não forem adequadamente executados, podem resultar em falhas graves. No volume de Os Trabalhadores do Mar, de Victor Hugo, em tradução feita por Machado de Assis em 1866 e que foi originalmente publicada como folhetim no jornal Diário do Rio de Janeiro, Junia Barreto (2012) aponta um erro, provavelmente no momento de organização dos cadernos para encadernação. O capítulo que encerra o romance e apresenta o suicídio de Gilliat, personagem central da trama, deixa de ser o último, devido ao deslocamento de um outro, intermediário, para o final do volume. Para compreender o engano, convém conhecer a estrutura da obra: Os Trabalhadores do Mar é dividido em três partes e cada parte é subdividida em livros, que, por sua vez, são separados em capítulos. 0 equívoco da edição da Abril foi ter transferido o capítulo final da segunda parte para a terceira, após o término efetivo do romance. Com isso, Gilliat, depois de tirar a própria vida, aparece no capítulo seguinte, mesmo "morto", travando sua épica luta contra o grande polvo no mar. Finda a batalha, o livro se encerra com o mesmo Gilliat, vitorioso, cantando a canção Bonny Dundee.

A versão utilizada para a reprodução do texto editado na Coleção e vertido em português por Machado de Assis foi publicada em 1866, no Rio de Janeiro, pela Tipografia Perseverança, no mesmo ano em que o romance de Victor Hugo saiu em folhetim. O volume original da primeira edição da tradução, já raro na década de 1970, foi cedido pelo famoso bibliófilo brasileiro Plínio Doyle para que fosse utilizado pela Abril. Através do acervo digitalizado da biblioteca Brasiliana Guita e José Mindlin, que conta com outro exemplar da primeira edição da tradução machadiana, 
pôde-se averiguar que o romance foi publicado com sua estrutura de capítulos correta.

Outra questão, observada em 1979 pela leitora Mônica Moreira de Mattos (1979) em carta enviada ao Jornal do Brasil, é a falta de revisão adequada no texto de $A$ Condição Humana, de Andre Mauraux. Ele tem diversas expressões não adaptadas do português escrito e falado em Portugal para o português escrito e falado no Brasil, já que a tradução do texto utilizado na Coleção foi feita por Jorge de Sena para ser publicada pela Edição Livros do Brasil, que é, à parte o nome, portuguesa.

Além dos problemas já identificados, em ao menos uma obra há condensação e supressão de partes do texto, contrariando a promessa da Editora em entregar um livro "sem cortes ou condensações", como apontou, em 1972, Edson Nery da Fonseca, em artigo publicado no Diário de Pernambuco (FONSECA, 1972, p. 4). No artigo, ele demonstra que o romance histórico "Os Noivos", de Alessandro Manzoni, sofreu cortes "da folha de rosto ao último capítulo", tendo sido retirados o subtítulo e a introdução, além de condensações que tornaram "os longos parágrafos de Manzoni [...] reduzidos a quase versículos na tradução - tradução ou traição? - da Sra. Mariana Guaspari”. Fonseca questiona, ainda, o motivo da escolha da Abril pela tradução condensada publicada originalmente pela editora carioca Irmãos Pongetti na década de 1940 ao invés da integral, editada pela Vozes em 1951. Salomão Jorge, em artigo para O Estado de São Paulo (JORGE, 1975, p. 54), volta a apontar a questão dos cortes na edição de Os Noivos pela Abril, reafirmando as inquietações de Fonseca e indicando que houve uma redução em mais de 200 páginas do equivalente ao texto original. Aurora Fornoni Bernardini, no prefácio da edição completa do romance, publicada pela Nova Alexandria, refaz o percurso das traduções de I Promessi Sposi e confirma o desfalque do texto da Irmãos Pongetti, que foi republicado, além da Abril, pela Tipografia do Centro, de Porto Alegre (s.d), e pela Tecnoprint/Ediouro na coleção Clássicos de Bolso, provavelmente em 1993 (BERNARDINI, 2012), também como "texto integral".

As falhas no texto ocorriam, sobretudo, por dois fatores, conforme identificado a partir do depoimento de Fernando Nuno (Anexo IV) ao autor: 1) sobrecarga de atividades em uma equipe relativamente pequena e sem recursos financeiros 
excedentes; 2) falta de tempo hábil para corrigir determinados erros, quando identificados. No tocante ao primeiro fator, apesar de o volume de trabalho ser grande, não havia destinação de profissionais em quantidade adequada para que a equipe pudesse conciliar as atividades ou mesmo remunerar possíveis colaborações. Um exemplo foi a preparação do texto do número referente à Ana Karênina, de Tolstoi, em que Boris Schnaiderman, tradutor e especialista em literatura russa, então professor de Língua e Literatura Russa da Universidade de São Paulo, auxiliou a edição, corrigindo falhas da tradução feita do francês - e não do russo - que a Abril havia comprado. Entretanto, Schnaiderman não era contratado da editora para o trabalho, nem consultor formal do volume. Nuno, ao sugerir à Abril que o professor fosse recompensado por seu auxílio, recebeu uma negativa como resposta, devido à alegada falta de verba. O agradecimento impresso no exemplar foi tímido demais para a dimensão do trabalho. O segundo fator explica o erro ocorrido em Os Noivos e identificado já na sua publicação: Nuno comunicou aos diretores da Coleção que a tradução do romance de Manzoni tratava-se, na verdade, de uma condensação do original. Entretanto, não havia mais tempo suficiente para corrigir a versão ou providenciar uma nova tradução antes de se publicar o livro, que deveria seguir a sequência da série, divulgada anteriormente no plano da coleção.

Ainda que os critérios de seleção e o cuidado com alguns títulos possam ser discutidos, é inegável o valor cultural da coleção, pela qualidade, de um modo geral, nas traduções dos textos, mas, principalmente, pelo fato de disponibilizar uma literatura pouco acessível à população em geral a valores reduzidos e com distribuição farta em bancas de jornais. Instrumentos fundamentais para a mediação entre o leitor não iniciado e o texto a ser lido, os fascículos que acompanhavam os livros introduziam o público ao contexto histórico em que o autor produziu a obra, abordando também sua biografia e bibliografia. Para sua produção, foi realizada uma pesquisa extensa em acervos da Europa e Estados Unidos "em busca de fotos, quadros e documentos" (IMORTAIS, 1970, p. 68).

Observados os pormenores referentes ao catálogo e ao texto, é necessário que se avalie outra particularidade das coleções, que resulta da convergência entre o panorama econômico social e o colecionismo, temas tratados até o momento. A materialidade dos livros, seu aspecto formal, é reflexo da perspectiva de interesse 
dos colecionadores para o qual foram editados e oferecem pistas valiosas para a compreensão da maneira como o processo editorial estava submetido à expectativa sobre o público consumidor.

Os livros de Imortais da Literatura Universal foram publicados com páginas do miolo no tamanho 13 por 19,2 cm, que resulta em 50 páginas, 25 de cada lado da folha de impressão no formato BB $(66 \text { por } 96 \mathrm{~cm})^{22}$. Este formato é utilizado por questões econômicas, já que permite um melhor aproveitamento da folha e da tinta pela mancha do texto, além de ser agradável para a leitura e o transporte, mesmo em volumes mais grossos, ao possibilitar bom encaixe entre as mãos. Eram lançados lacrados em embalagens plásticas transparentes, com o fascículo incluso no pacote, junto à contracapa.

A capa (Fig. Figura 14) foi produzida em acartonado revestido de papel recoberto com lâminas vinílicas (PVC), de textura emborrachada, que remete à aparência do couro, estendendo-se por cerca de $0,5 \mathrm{~cm}$ para as guardas, formando a seixa. O tamanho é 13,5 por $20,5 \mathrm{~cm}$ com o livro fechado (aproximadamente 14 por $21 \mathrm{~cm}$, o tradicional formato americano, em que parte das brochuras nacionais costumavam - e ainda costumam - ser impressas). Gravados em dourado por hot stamping ${ }^{23}$, apareciam o nome do autor, título do livro e nome da Editora, emoldurados por ornamentos e arabescos retratando folhas, flores e linhas.

A lombada (Fig. Figura 14), lisa, sem nervuras, também continha arabescos e ornamentos, expondo as informações do número do volume, autor da obra, título e símbolo da editora, enquanto a contracapa não ostentava nenhum tipo de impressão. Para as folhas de guarda foi empregado papel de maior gramatura que o do miolo, sem qualquer impressão. Os cadernos foram costurados com linha branca de tecido, e sobre sua lombada foram utilizados cabeceados (fig. Figura 15), tiras de tecido que protegem e adornam volumes em capa dura, com alternância entre o vermelho e o amarelo, tons que se harmonizam aos da capa, oferecendo um aspecto sóbrio e elegante ao conjunto. Os livros eram encadernados nas próprias

$22 \mathrm{O}$ formato foi medido nos exemplares, mas pode haver variações devido ao processo de refile.

23 Técnica de impressão em que uma folha colorida é prensada contra o suporte (cartão, papel, courino etc.) por uma matriz quente com formas em relevo (palavras, desenhos, ornamentos), de maneira que fique gravada em baixo relevo, como um decalque, no suporte. 
oficinas gráficas da editora, em setor dedicado a esta operação, o Departamento de Produção de Capas e Volumes, e passavam por um processo de inspeção registrado em um pequeno bilhete (Fig. Figura 16) em papel, no tamanho de 10,3 cm por $4,1 \mathrm{~cm}$, que seguia em cada um dos livros, como forma de garantia em caso de problemas na encadernação.

Ao abrir os volumes, nota-se que o tipo utilizado em todo o texto é de família com serifas, exceto o utilizado para o nome do autor na folha de rosto (Fig. Figura 17). Esta, por sua vez, segue o padrão "autor - título - símbolo da Editora - data", embora com diferenças de composição em alguns exemplares, como será abordado adiante. As fontes serifadas são as mais utilizadas no corpo do texto de livros extensos, principalmente os de fiç̧ão, por permitirem melhor legibilidade, já que suas hastes são dotadas de pequenos prolongamentos observáveis no limite dos tipos, especialmente notados pelos olhos na parte superior das letras, facilitando a distinção entre as letras, sinais gráficos e palavras. No decorrer da leitura, as fontes serifadas tornam a atividade menos cansativa por facilitar que os olhos compreendam mais facilmente o texto.

O colofão, padronizado, informa o número do fascículo, o nome da coleção e os dados da editora. É possível observar, pelos dados, que o livro é considerado parte integrante do fascículo e não o contrário, ou, como informado, comprava-se o livro e obtinha-se, como brinde, o fascículo. Este tipo de associação foi feito apenas em Os Imortais da Literatura Universal, tendo sido abandonada nas coleções posteriores, mesmo as de livros acompanhados de fascículos. Todos os elementos pré e pós-textuais (falsa folha de rosto, folha de rosto, folha de créditos e colofão) mantêm o padrão de tamanho (corpo) e peso (normal) nos tipos de todos os volumes da Coleção, ainda que, no miolo, haja variações de tamanho entre cada título, sendo os textos de menor extensão apresentados em fontes maiores e os mais extensos em corpos menores.

Conforme Simon Garfield (2012), o espaçamento entre uma linha e outra, a entrelinha, é mais um elemento importante para a leitura, pois quando este intervalo é muito curto, menor que o tamanho do tipo, dificulta a diferenciação entre as linhas, amentando o esforço visual e a fadiga ocular do leitor. Da mesma forma, o espaçamento entre as letras das palavras (conhecido como kerning) e a quantidade 
de palavras por linha (idealmente, as linhas devem ser compostas contendo entre dez a doze palavras) são elementos que devem ser considerados no momento da composição. Já os tipos devem ser escolhidos de preferência entre aqueles que apresentem contraste entre os traços grossos e finos que os compõem, e que a metade superior de suas letras, que tem maior leiturabilidade, possua variedade na largura. Os elementos de espaço e escolha do tipo definem o quão agradável o processo de leitura pode ser e são elementos fundamentais para a experiência do leitor. 
Figura 14 - Padrão de capa e lombada dos exemplares da Coleção

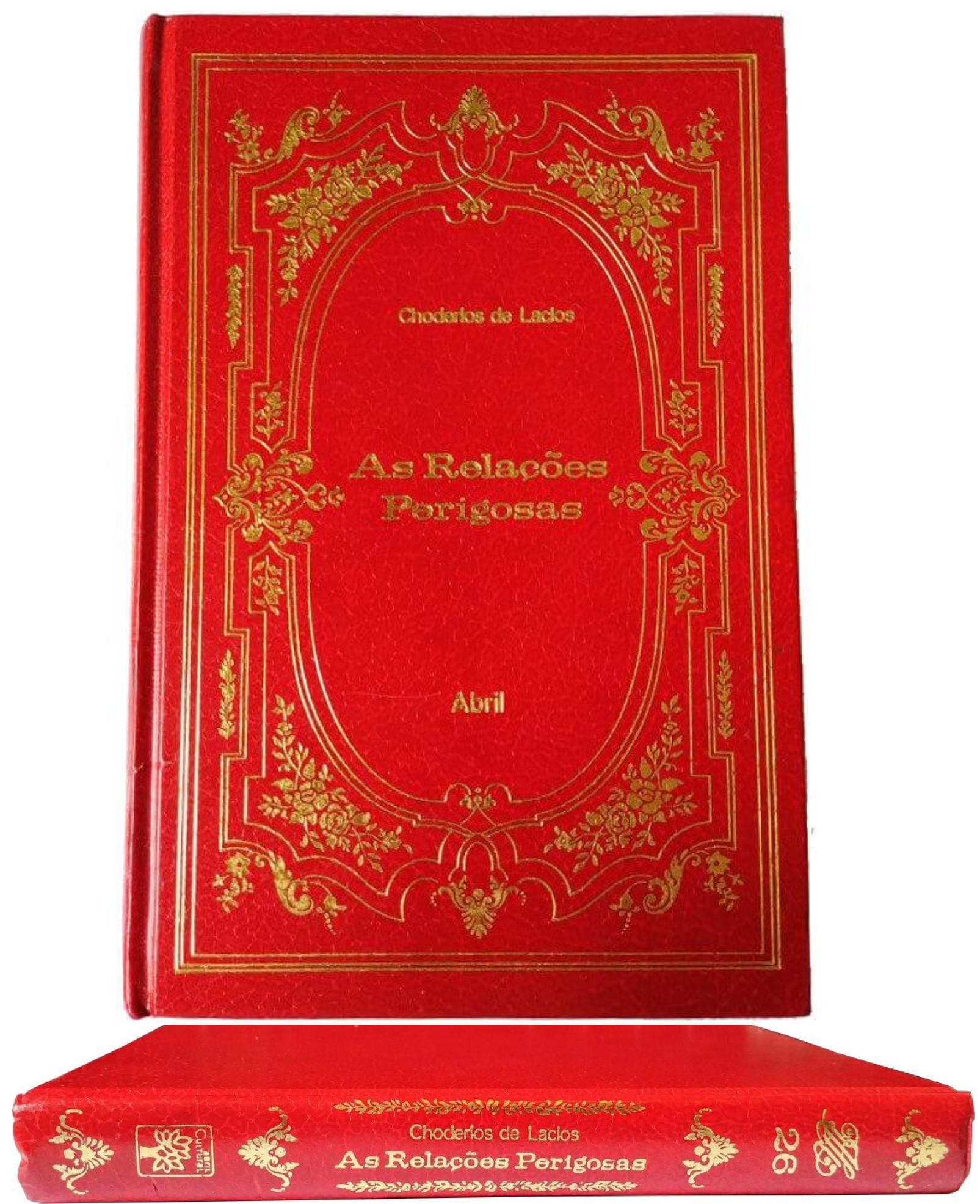

Fonte: acervo pessoal do autor. 
Figura 15 - Cabeceado padrão utilizado em todos os exemplares da Coleção

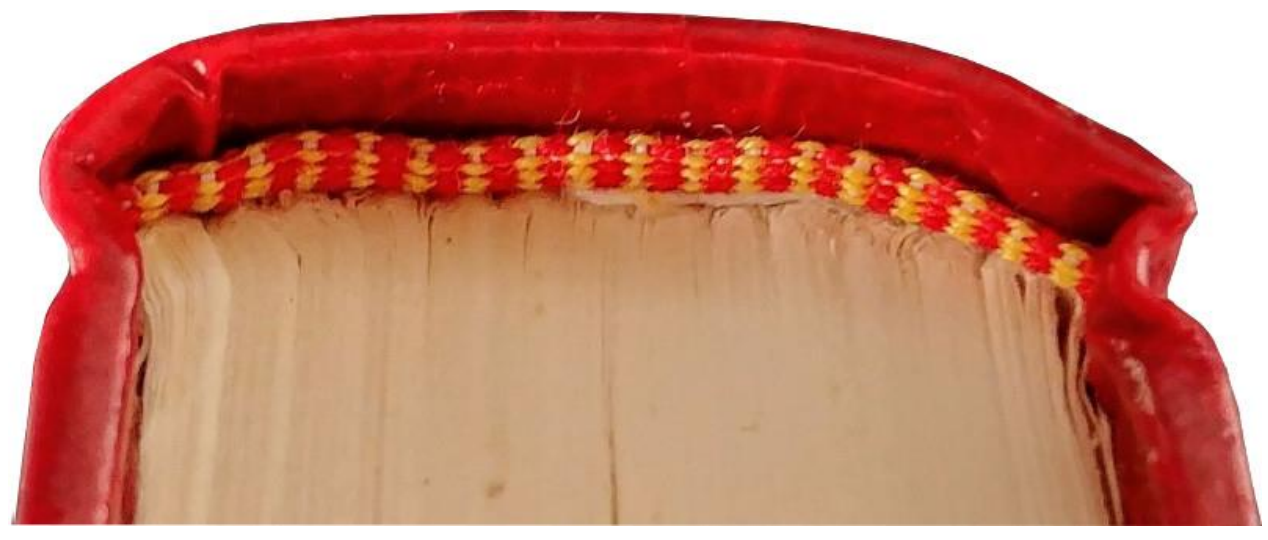

Fonte: acervo pessoal do autor.

Figura 16 - Ficha com o registro do nro. de inspeção para garantia da encadernação

\section{ABRIL S/A. CULT. E IND.}

Depart. ${ }^{\circ}$ de Produção de Capas e Volumes. Em caso de reclamação, favor apresentar esta -etiquêta.

INSP N. ${ }^{\circ}$

$$
78 \% 8
$$

Fonte: acervo pessoal do autor. 
Figura 17 - Folha de rosto padrão nos exemplares da Coleção

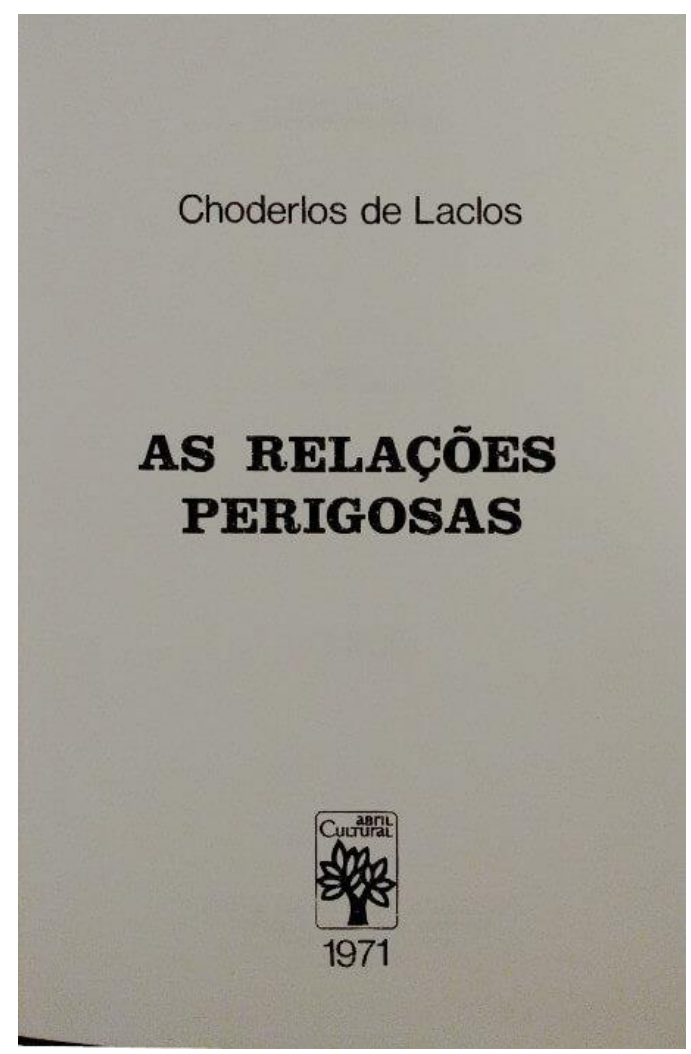

Fonte: acervo pessoal do autor.

Os livros da coleção Os Imortais da Literatura Universal possuíam uma padronização na encadernação, mas o mesmo não ocorria com a composição e diagramação. Conforme indicado, as características poderiam variar de acordo com o tamanho do texto, muitas vezes resultando em escolhas inadequadas para que uma obra mais extensa coubesse nos limites razoáveis de um livro, que não deveria ser espesso demais, a ponto de prejudicar a portabilidade, nem ter a necessidade de ser dividido em mais de um volume. A seguir, serão analisados três títulos diferentes publicados na coleção, para que se possa observar de que maneira foi feita a editoração de cada um.

O primeiro exemplo é Tom Jones, de Henry Fielding, nono título publicado na coleção. O romance possui 620 páginas, numeradas da página 9 à página 614, e é dividido em 18 livros, com capítulos variáveis em cada um, e a espessura é de $4 \mathrm{~cm}$, somados o miolo e as capas. A folha de rosto contém um erro de composição (Fig. Figura 18), apresentando sua linha principal no centro ótico da página e não no terço 
superior, como preconiza Jan Tschichold (2007). Ao se observar as páginas expostas nas figuras 19 e 20, pode-se notar, a princípio, que a mancha tipográfica do texto, elemento constituído pelo conjunto de linhas impressas na página, possui posições diferentes, ocasionadas por erro no refile ou montagem do caderno da figura 19, o que implica em seu deslocamento para a parte superior direita da página, enquanto a figura 20 é um modelo com espaçamento de margens provavelmente projetado pelo diagramador, cerca de $1,5 \mathrm{~cm}$ nas margens superior, inferior e externa e $1 \mathrm{~cm}$ na interna, dimensões também seguidas na maioria dos cadernos do volume. A mancha tipográfica mede 9,9 cm de largura por 16,7 cm de altura (16,8 em determinadas páginas). Encontram-se, ainda, algumas páginas com manchas desalinhadas verticalmente (inclinadas à esquerda).

A escolha por um corpo (fonte) pequeno e entrelinhamento estreito produz uma mancha muito compacta, que pode dificultar a leitura de uma linha a outra e causar a perda de sequência no texto. Como a ficção é um gênero em que as pessoas permanecem por maior tempo no processo de leitura, a atividade se torna exaustiva e a sensação de fadiga e cansaço podem surgir. $O$ que melhora um pouco a legibilidade é a extensão das linhas, que, em geral, não ultrapassam 65 caracteres, quantidade considerada ideal. Acima disso, segundo Jan Tschichold (2007, p. 154), exigem espaçamento de entrelinha generoso para evitar a dificuldade que os olhos têm em saltar de uma linha a outra sem se confundirem, pois "o olho acharia difícil captar a linha seguinte". O autor ainda recomenda que se evite linhas muito grandes ou então se aumente o tamanho da fonte. A legibilidade é um fundamento importante, especialmente quando o público não está habituado à leitura, evitando que uma composição desagradável o afaste.

O segundo exemplar a ser analisado é o volume de número 26 da Coleção, que trouxe a edição de As Relações Perigosas, romance epistolar do autor francês Choderlos de Laclos, em tradução de Sérgio Milliet originalmente publicada pela Difusão Europeia do Livro em 1961, com notas de Yves Le Hir e introdução de Mário da Silva Brito. A introdução e as notas foram excluídas da edição feita pela Abril, que conta com 324 páginas, numeradas da página 11 a 319, num volume de 2,4 cm de espessura e com texto dividido em duas partes, que compõem, em conjunto, as 175 cartas da obra. 
A composição do texto de As Relações Perigosas é mais arejada que a de Tom Jones, com margens superior, inferior e externa de $1,7 \mathrm{~cm}$ e interna de $1 \mathrm{~cm}$. Embora haja muita variação entre os cadernos, a mancha se mostra mais bem distribuída pela página, o que, em conjunto com entrelinhamento maior em relação ao romance de Fielding, torna a leitura de Laclos mais agradável (fig. Figura 21), ainda que o corpo seja o mesmo entre os dois livros. $O$ exemplar que foi analisado contém erros no padrão do refile ou encadernação, resultando em margens que alcançam $2 \mathrm{~cm}$ (externas e superiores); $1,4 \mathrm{~cm}$ (inferiores) e menos de $1 \mathrm{~cm}$ (internas) em alguns cadernos. Estas diferenças também são resultado da variação na altura da mancha, entre $15,9 \mathrm{~cm}$ e $16,7 \mathrm{~cm}$, a maior entre todos os exemplares avaliados, bem como no desalinhamento da mancha tipográfica em relação à página. A folha de rosto segue um melhor padrão de distribuição das informações, com o autor no nível superior da página, título centralizado, editora e ano de publicação na extremidade inferior, apesar de ser aconselhável (TSCHICHOLD, 2007; BRINGHURST, 1996) a concentração das informações principais (autor e título) no topo da página e os dados de edição e ano de publicação na parte inferior. 
Figura 18 - Folha de rosto mal-composta no exemplar de Tom Jones

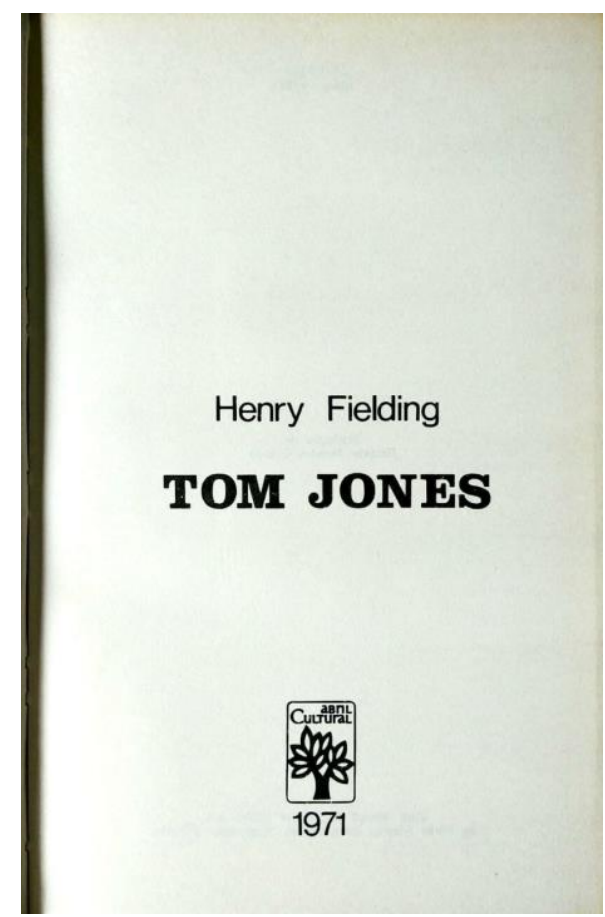

Fonte: acervo pessoal do autor.

Figura 19 - Erro de corte em um dos cadernos de Tom Jones

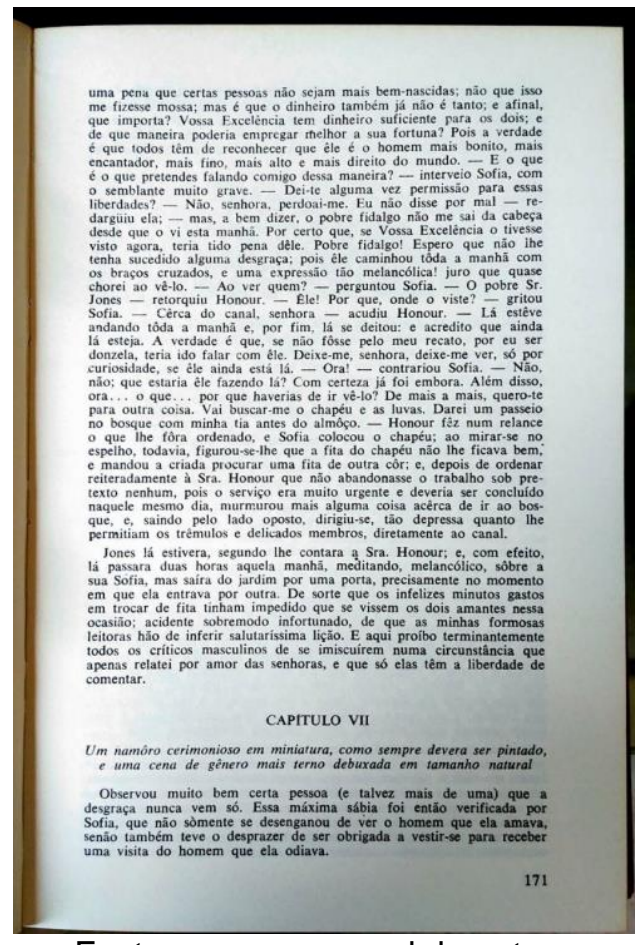

Fonte: acervo pessoal do autor.
Figura 20 - Página de Tom Jones com diagramação

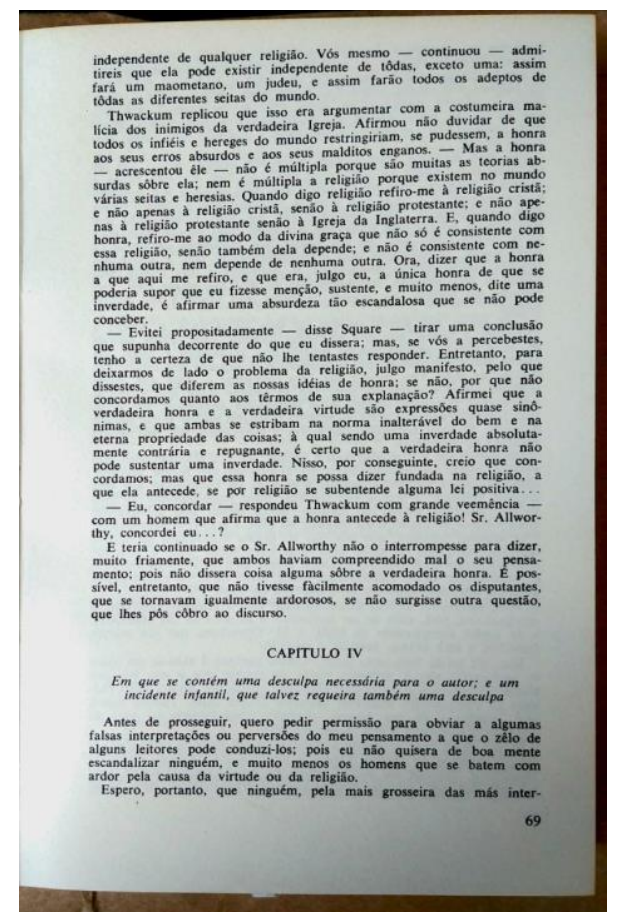

Fonte: acervo pessoal do autor. 
Figura 21 - Comparação entre um fragmento do miolo de Tom Jones (acima) e As Relações Perigosas (abaixo)

O escândalo, portanto, nunca teve acesso à sua mesa; pois, assim como foi há muito observado que se pode conhecer um homem pelos seus companheiros, assim me afoitarei a dizer que se podem conhecer os princípios religiosos e políticos, o discernimento e, em realidade, todo ๑ caráter de um grande homem ouvindo a conversação que se trava à sua mesa: pois, embora uns poucos sujeitos esquisitos expressem em tôda parte seus pensamentos, grande parte do gênero humano tem o suficiente do cortesão para acomodar as suas práticas ao gôsto e à inclinação dos superiores.

do perdidas.

O desejo que tinha de ser informada fêz-me ficar junto da Sra. de Volanges, que se deitou ao chegar; e, depois de ter ceado ao lado dela, com a filha, deixamo-la cedo, a pretexto de que ela precisava de descanso, e passamos ao aposento da pequena. Esta fizera, por seu lado, tudo o que esperava dela: escrúpulos liquidados, novos juramentos de amar sempre, etc., etc. Agiu, enfim, com boa vontade, mas o tolo Danceny não ultrapassou o ponto em que estava antes. Ah, com êsse pode-se brigar; as reconciliações não são perigosas.

Fonte: acervo pessoal do autor.

O terceiro e último exemplar da coleção Os Imortais da Literatura Universal a ser analisado é Ficções, do prosador e poeta argentino Jorge Luis Borges, que encerrou os 50 volumes da coleção, em 1972. Inicialmente publicado pela Editora Globo de Porto Alegre no ano anterior, sob a tradução do poeta gaúcho Carlos Nejar, figurou na lista dos livros mais vendidos no início de 1971 pela editora gaúcha, sendo um dos raros casos de obra com sucesso recente por outra casa a constar em uma coleção da Abril. A edição conta com 192 páginas no miolo, numeradas da 15 a 189, que, somadas à capa, produzem um volume de 1,7 cm de espessura.

A coletânea de contos de Borges possui o mesmo equívoco de outros exemplares em relação à composição da folha de rosto, por centralizar o nome do autor e título da obra. Entretanto, devido ao fato de não ser um texto extenso, a fonte é de maior corpo e as entrelinhas adequadas, proporcionando uma agradável experiência de leitura. As margens apresentam oscilações, com as externas variando entre $1,5 \mathrm{~cm}$ a $1,7 \mathrm{~cm}$; superiores de $0,7 \mathrm{~cm}$ a 2,8 cm; internas entre $1,3 \mathrm{~cm}$ a $1,5 \mathrm{~cm}$ e inferiores entre $1,2 \mathrm{~cm}$ a $2 \mathrm{~cm}$. A mancha tipográfica possui $9,8 \mathrm{~cm}$ de largura e $16 \mathrm{~cm}$ de altura. Entre os exemplares analisados, este foi o único em que foram identificadas variações entre páginas de um mesmo caderno, além de várias 
páginas com manchas tortas (levemente inclinadas à esquerda), em que não é possível reconhecer se se trata de um erro de impressão, refile ou encadernação.

Realizadas as avaliações, observa-se que algumas situações são constantes. Uma delas é o problema de padronização da folha de rosto, que, nos três exemplares, apresentam composições distintas. Em uma coleção, embora seja compreensível a variação na tipografia do texto, devido a diferentes extensões das obras e limitações oferecidas pelo planejamento dos custos, seria ideal que, assim como a encadernação, a folha de rosto fosse bem composta e padronizada entre todos os títulos.

O poeta e tipógrafo canadense Robert Bringhurst (1996), assim como Tschichold (2007), são referências no campo do design de livros. Ambos recomendam, como já informado, a composição da folha de rosto com os elementos principais (autor e título) na região superior da página e a indicação do editor e ano de publicação no segmento inferior. A composição com elementos distribuídos pela página pode ser bonita e correta, se bem composta, mas não é recomendada a concentração dos elementos essenciais no centro. Bringhurst defende a importância do espaço em branco para a estética da composição de uma folha de rosto, já que não se deve "[...] simplesmente descarregar algumas letras grandes e préfabricadas no centro do espaço, nem cavar alguns buracos no silêncio com pesadas maquinarias tipográficas e depois seguir em frente", como fez a Abril em seus exemplares. Trata-se, aqui, de elementos clássicos de tipografia, que parecem ser ideais para uma coleção de obras igualmente clássicas. A composição do livro deve estabelecer um conjunto adequado ao tipo de texto, uma vez que a forma influencia o sentido e a apropriação da informação, conforme estabeleceu McKenzie (1999).

Os três livros analisados cometem, ainda, o equívoco na diagramação das margens em alguns cadernos, provavelmente devido a erros no refile ou na encadernação dos exemplares. As muitas variações de tamanho nas margens podem atrapalhar o leitor em alguns momentos. Conforme Hendel (2003), as margens internas devem ser menores que as laterais, o que produz o efeito de unidade entre o conjunto das manchas paralelas em cada página. A margem inferior deve ser larga o suficiente para que o leitor possa segurar o livro pela sua extremidade sem que os polegares obstruam o texto, da mesma maneira que as 
margens laterais devem ser bem espaçadas para que se possa segurar pelos lados da página sem empecilhos à leitura. Como se vê, além de questões estéticas, a boa proporção das margens possui fundamentos voltados à ergonomia da leitura.

Observadas as individualidades dos exemplares, um elemento fundamental na produção dos livros e que merece destaque é o papel. No que diz respeito ao que foi utilizado na coleção, a análise material de um exemplar, transcorridas quase cinco décadas da publicação, permite que se encontre algumas características interessantes em seu processo de produção. Ao serem analisadas as figurasFigura 22 e 23, é possível notar que algumas páginas de um mesmo volume apresentam uma coloração amarelada, muito distinta das demais, ainda alvas. O amarelamento é resultado da acidificação das fibras de celulose do papel, que ocorre por deficiências na produção, entre as quais a não eliminação da lignina, substância acidificante presente nas plantas e que favorece a degradação acelerada do suporte; utilização de água com ph ácido; e emprego de aditivos químicos que, individualmente ou em reação, são ácidos. Esses fatores, aliados à presença de luminosidade, umidade e temperatura inadequados, aceleram o processo de degradação das fibras celulósicas, tornando o papel amarelado, pouco maleável, esfarelento e quebradiço, promovendo danos muitas vezes irreversíveis à obra.

Convém notar que no início da década de 1970, quando a coleção foi publicada, havia uma crise internacional no fornecimento de papel. Entre 1970 e 1971, houve, de acordo com Roberto Amaral Vieira (1975, p. 157-159), inflação de "30\% no preço do papel nacional", devido à demanda interna superior à oferta e à decisão governamental em estimular a exportação de celulose nacional, a partir de incentivos fiscais, devido à falta da matéria-prima no exterior, diminuindo sua disponibilidade no mercado nacional. Ainda, segundo Vieira (1975, p. 160-162), naquele período, a indústria papeleira nacional, de forma geral, apresentava estrutura obsoleta; baixa capacidade técnica dos funcionários; tecnologia de produção ineficiente; quase inexistência de controles de qualidade e "grande variação na qualidade dos papéis produzidos, entre empresas e até mesmo entre uma partida e outra da mesma fábrica”. Este último apontamento, em especial, pode explicar o motivo de um mesmo exemplar contar com características tão díspares no papel do miolo. 
A diferença entre a presença de acidez nas páginas do volume é um indicativo importante de que foi utilizado mais de um tipo de papel em sua produção, de qualidades distintas, de um mesmo fornecedor ou de fornecedores diversos. As coleções da Abril, conforme Richard Civita (informação verbal) ${ }^{24}$, foram impressas com papel adquirido de duas grandes empresas: a brasileira Suzano e a estadunidense International Paper. Esta última, no entanto, só se inseriu no Brasil em 2000, com a aquisição da Champion Papel e Celulose, o que inviabiliza a possibilidade de ter produzido papel para a Abril na década de 1970, embora a Champion o possa ter feito, pois a subsidiária brasileira da Champion Inc. operava no país desde 1960. O papel adquirido era sempre o melhor disponível, conforme Civita, mas, pelo que indica o exemplar em questão, em alguns casos papéis de menor qualidade precisavam ser utilizados por não haver no mercado quantidade suficiente do insumo usual.

Figura 22 - Diferença de papéis utilizados em um mesmo volume, identificáveis pelo nível de acidificação

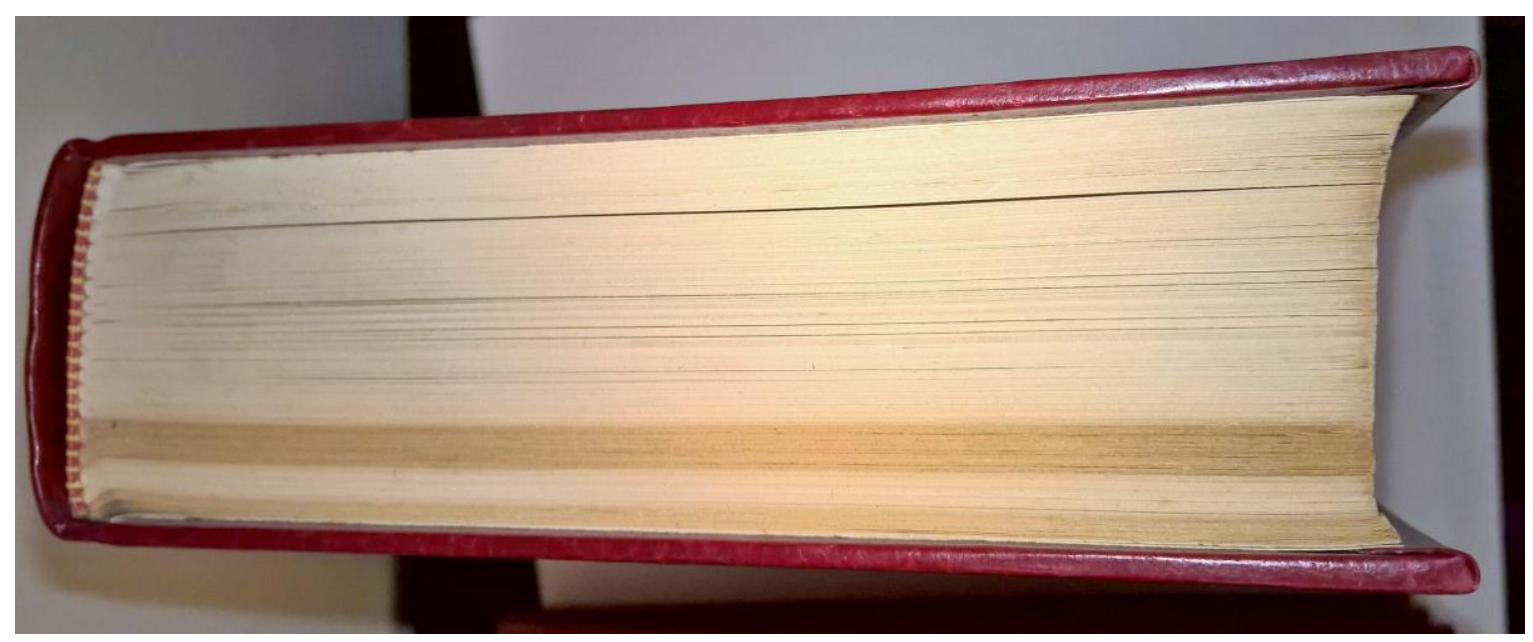

Fonte: acervo do autor.

24 Entrevista ao autor em dezembro de 2015. 
Figura 23 - Diferença de nível de acidificação entre páginas de um mesmo volume

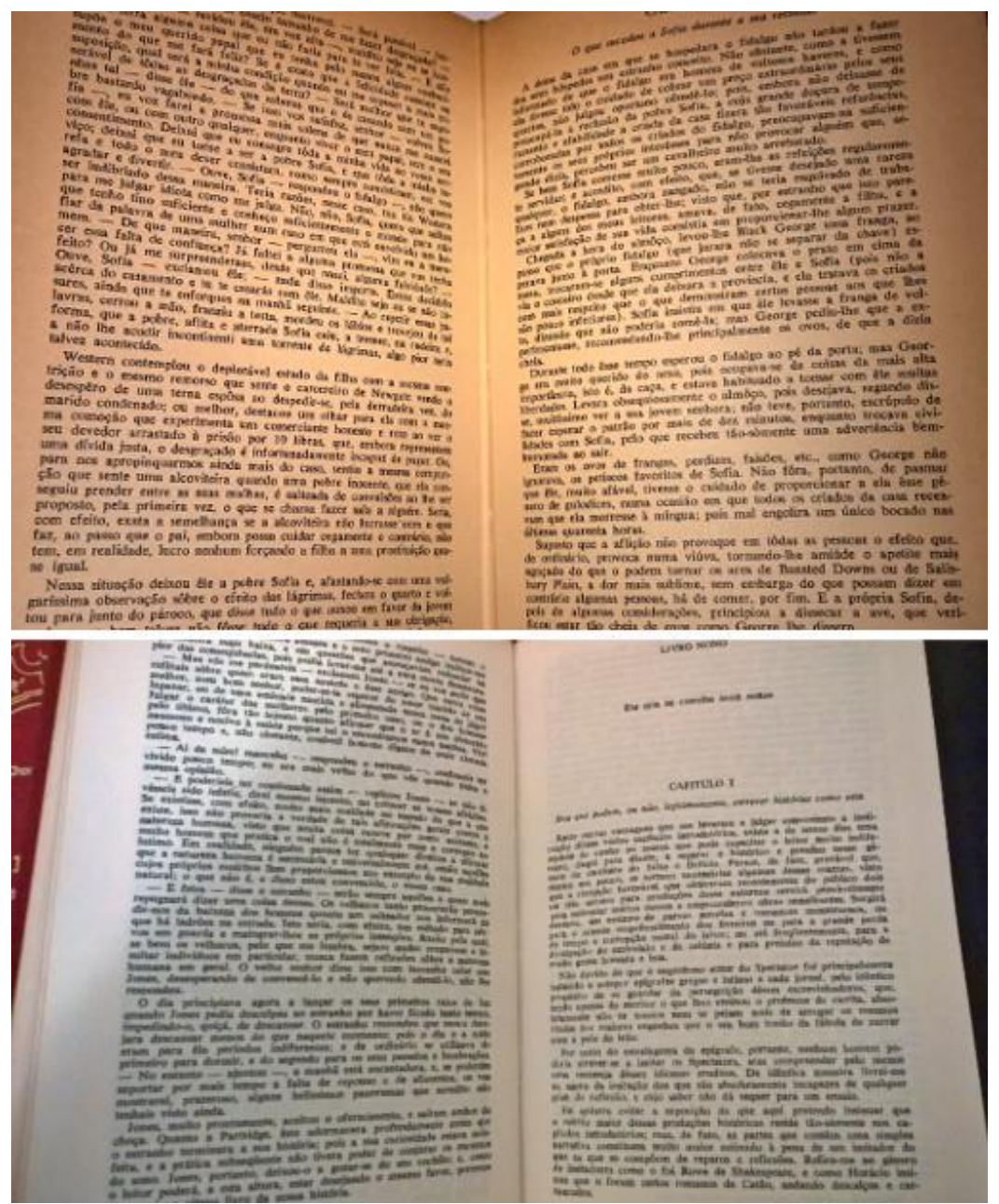

Fonte: acervo do autor.

Voltando à questão da capa, uma situação chama a atenção ao se observar um exemplar da coleção Os Imortais da Literatura Universal, encontrado para comercialização em lojas de livros usados: diferente do padrão identificado nos volumes da coleção anteriormente avaliados, este possui capa e contracapa marrom, sem ornamentos, apenas com a lombada impressa em hot stamping em tom dourado, com o nome do autor e da coleção em fundo verde (Fig. 24). Nas guardas das capas, encontra-se o símbolo da Abril e o nome da Editora impressos em marrom sobre fundo em tom pastel, repetidos várias vezes de maneira a preencher todas as folhas de guarda do volume (Fig. Figura 25). 
Figura 24 - Capa e lombada marrom da Coleção Os Imortais da Literatura Universal

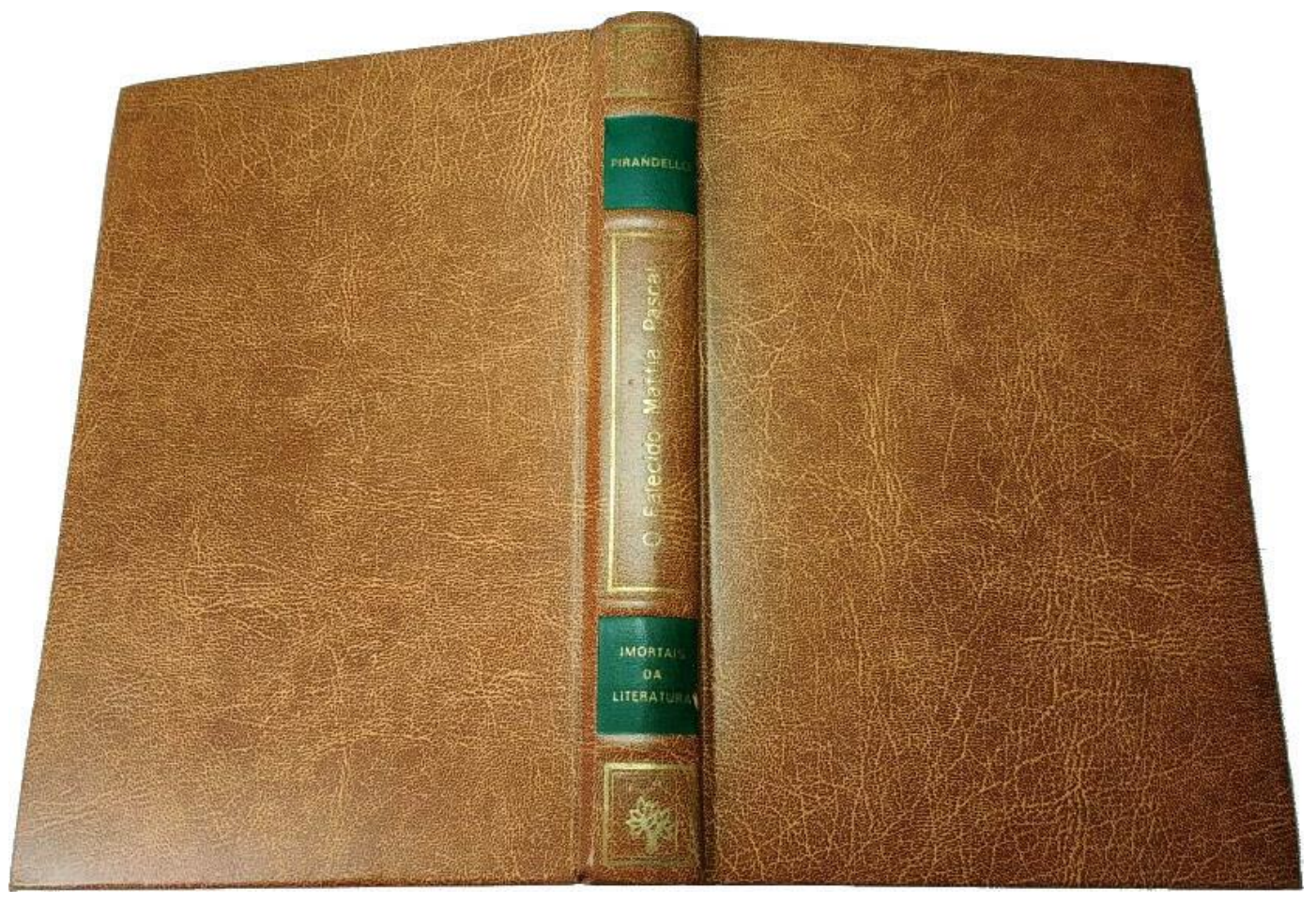

Fonte: acervo pessoal do autor.

Figura 25 - Folhas de guarda dos exemplares de capa marrom

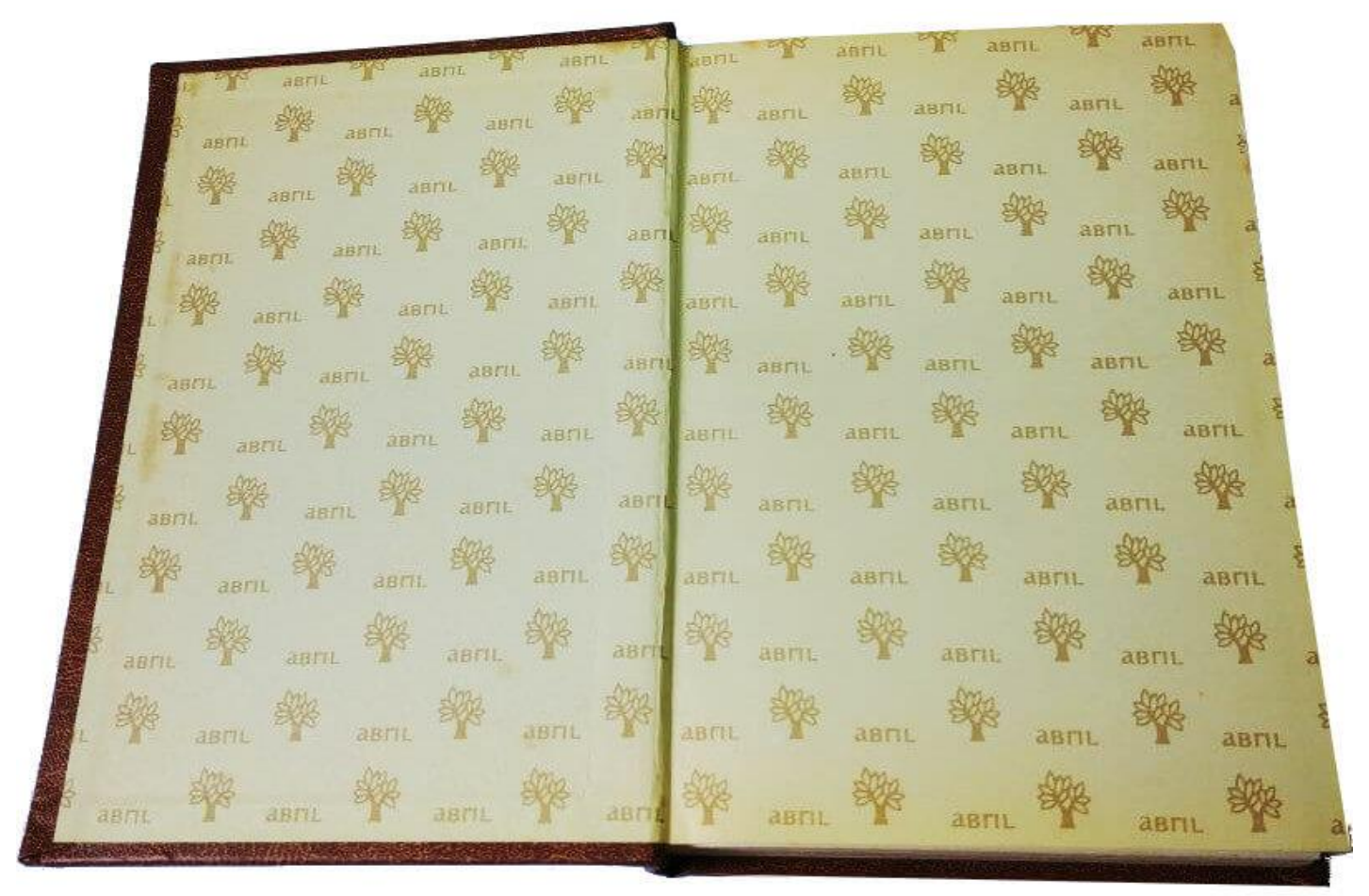

Fonte: acervo pessoal do autor. 
A diferença das capas existia por questões de estratégias de distribuição. A coleção com capa marrom foi editada em 1973 e comercializada completa, pelo sistema porta-a-porta, produzida especificamente para este fim (informação verbal) ${ }^{25}$. No entanto, é possível que tivessem feito parte do sistema volumes que encalharam na venda em bancas, uma vez que o capítulo número um da biografia dos autores (equivalente ao fascículo número um que circulou em bancas de jornais) é datado de 1973, mas o exemplar de As Aventuras do Sr. Pickwick, de Charles Dickens (segundo livro da coleção), traz em sua folha de rosto o ano de 1971 como o de publicação, ou seja, a mesma data dos que foram vendidos com capa vermelha nas bancas. A esta hipótese, corrobora a reportagem sobre a Editora Abril publicada na Revista Expansão, em junho de 1972, onde se informa que "após o término de uma coleção de fascículos nas bancas, ela é transformada em novo produto. É reorganizada e encadernada. Depois é vendida pelo sistema porta-em-porta" (A INCESSANTE..., 1972). A reportagem não deixa claro se os fascículos transformados em coleções de livros eram sobras e recolhas ou novas impressões. É provável que fossem um pouco de cada. Outra possibilidade é que, na reimpressão dos exemplares, os editores não tenham se atentado para a modificação do ano de publicação, utilizando as mesmas matrizes da edição anterior. O sistema porta-a-porta será melhor abordado no quarto capítulo deste trabalho, quando ocorrerá a apresentação das estratégias de distribuição das edições da Abril Cultural.

Não menos importantes foram os fascículos que acompanharam os livros. Responsáveis por introduzir o leitor ao panorama político, econômico e social, bem como apresentar o autor através de sua biografia e bibliografia, constituíram-se em instrumentos fundamentais na mediação e apropriação dos textos. Compostos de 20 páginas em papel couchê de maior gramatura, das quais quatro páginas formavam as capas, que não deveriam ser encadernadas ao final da coleção, ainda que no verso da capa de cada fascículo estivesse a cronologia do autor em questão. Assim a Editora revelava o plano da obra e aconselhava o colecionador, no primeiro fascículo, referente à Dostoiévski:

OS IMORTAIS DA LITERATURA UNIVERSAL trará ao leitor, quinzenalmente, um fascículo e um livro famoso, completo, sem cortes ou condensações. O primeiro contará a história da vida e obra de um grande 
nome da literatura universal. O livro será um dos melhores romances ou novelas do escritor focalizado. Ao final da série, o leitor terá uma coleção de cinquenta obras célebres, e mais três volumes compostos pelos fascículos encadernados.

Cada fascículo terá vinte páginas: quatro capas, e dezesseis páginas internas; apenas estas deverão ser encadernadas. Retiradas as capas dos fascículos, encaderne-os seguindo a ordem dos números que figuram na primeira página. Assim, "Dostoiévski no. 10" constituirá o décimo capítulo da série. As capas serão postas à venda juntamente com os fascículos números 17,35 e 50 . A coleção propiciará ao leitor uma visão básica da literatura narrativa desde a Renascença até o século XX. Este fascículo não pode ser vendido separadamente do livro que o acompanha.

Segundo instruções da própria Abril, os encadernadores deveriam descartar as capas na hora da encadernação, o que fez toda a cronologia dos autores estar ausente dos volumes finais de biografias. Entretanto, durante a pesquisa de fontes para este trabalho, foi possível encontrar, em um alfarrábio, um exemplar formado e encadernado à parte pelo diligente colecionador que antes o possuiu com todas as capas e contracapas dos fascículos, com a lombada inscrita sob o título de "Cronologia" (Fig. Figura 26). É um volume raro, diferente dos outros da coleção, que nas investigações posteriores em sites especializados em vendas de livros, no Brasil e no exterior, não é comercializado junto a nenhuma das coleções completas postas à venda, nem como volume individual, o que permite considerar que a encadernação das "capas descartáveis" não era algo comum.

Figura 26 - Lombada de livro formado pela encadernação das capas "descartáveis" dos fascículos de Os Imortais da Literatura Universal

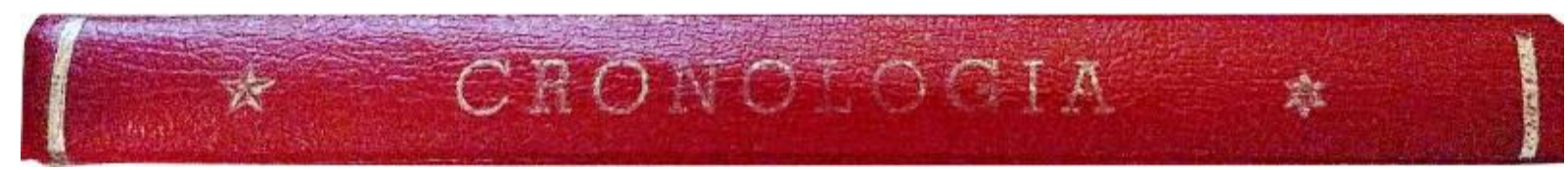

Fonte: acervo pessoal do autor.

Os fascículos eram impressos no mesmo formato dos livros; um erro, visto que, no momento da encadernação, para produzir a folga das capas, o encadernador precisava refilá-los, reduzindo o tamanho das margens (Fig. Figura 27). As capas foram colocadas à venda pela Abril nas bancas de jornais junto aos números 17, 35 e 50, conforme o plano da coleção, e os colecionadores dispunham de uma lista de encadernadores oficiais oferecidos pela própria editora para executar o serviço. Apesar do problema no formato, eram fartamente ilustrados e dotados de um texto em linguagem acessível, além de exibirem imagens que poderiam ser 
consideradas polêmicas pelo público mais conservador em seus costumes, como nus artísticos em alguns números (Fig. Figura 28). Os fascículos constituíam, também, um importante gatilho de compra para o próximo volume da série ao mencionarem, na contracapa, o exemplar subsequente, com uma pequena sinopse da história e grandes ilustrações que retratavam os autores e, em alguns casos, personagens (Fig. Figura 29) da próxima obra.

Figura 27 - Fascículos encadernados e refilados, com a paginação no limite do corte

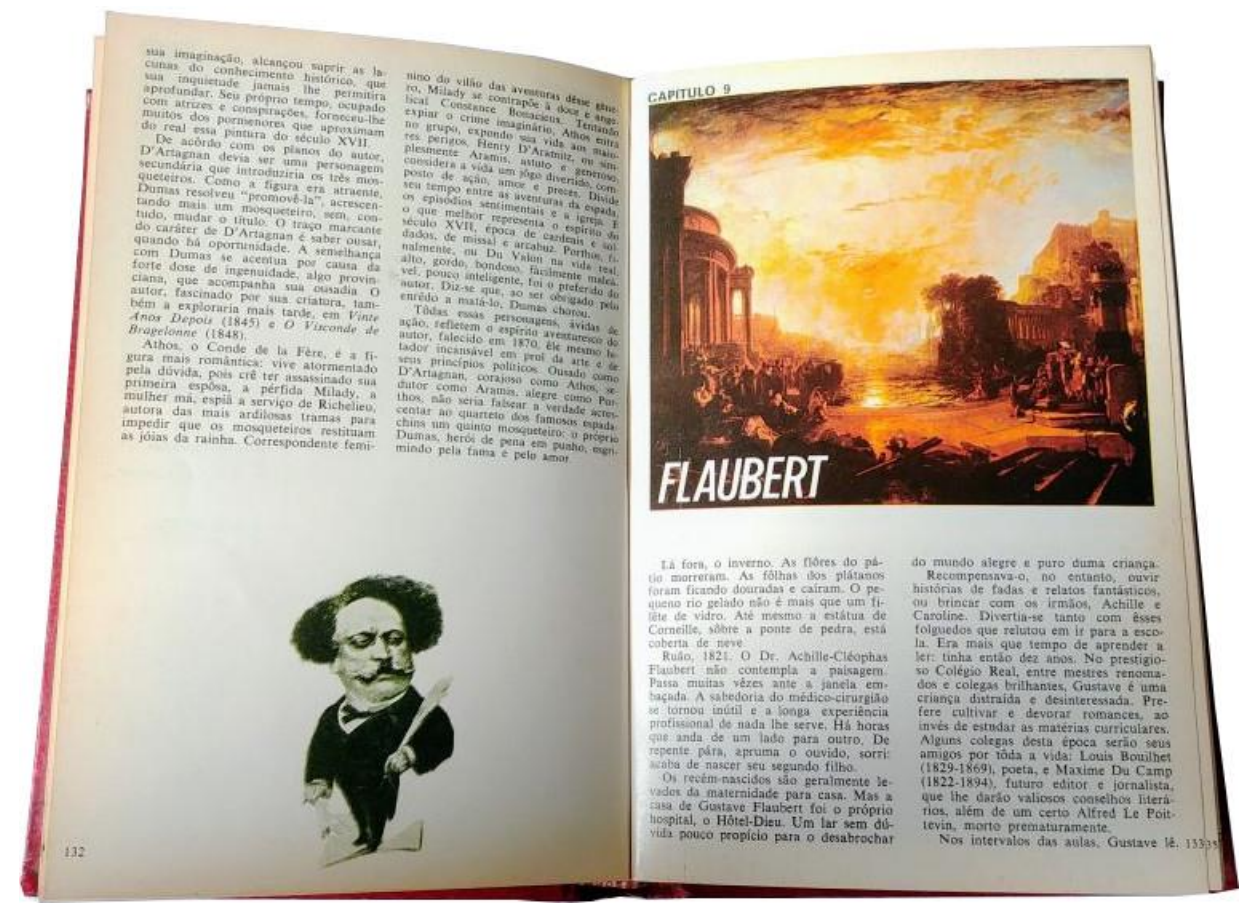

Fonte: acervo pessoal do autor. 
Figura 28 - Interior de um fascículo sobre Gabrielle Colette, ilustrado com um nu de Modigliani

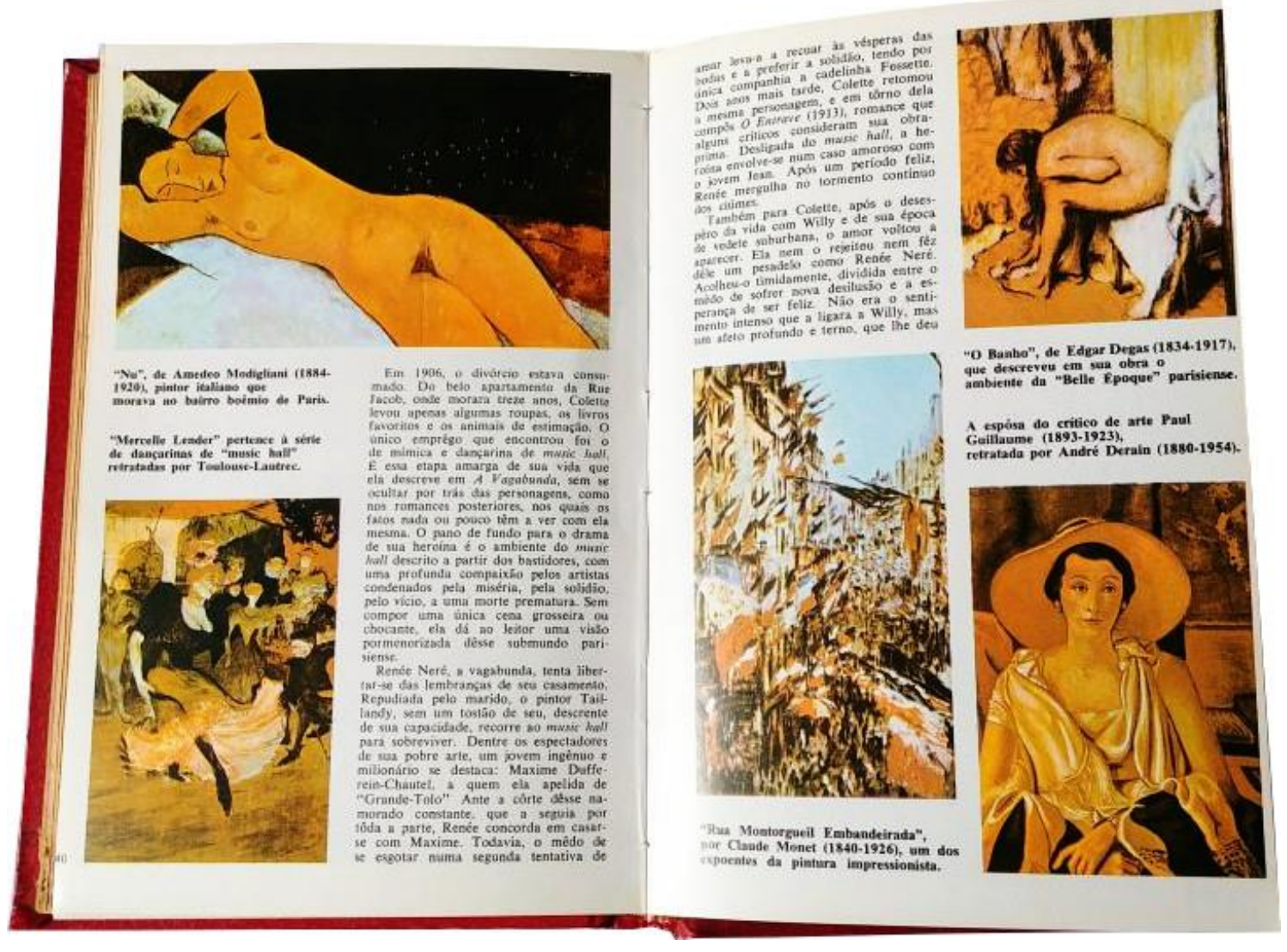

Fonte: acervo pessoal do autor. 
Figura 29 - Contracapa do Fascículo dedicado à Turguêniev, com propaganda do próximo exemplar, Retrato do Artista quando Jovem, de James Joyce

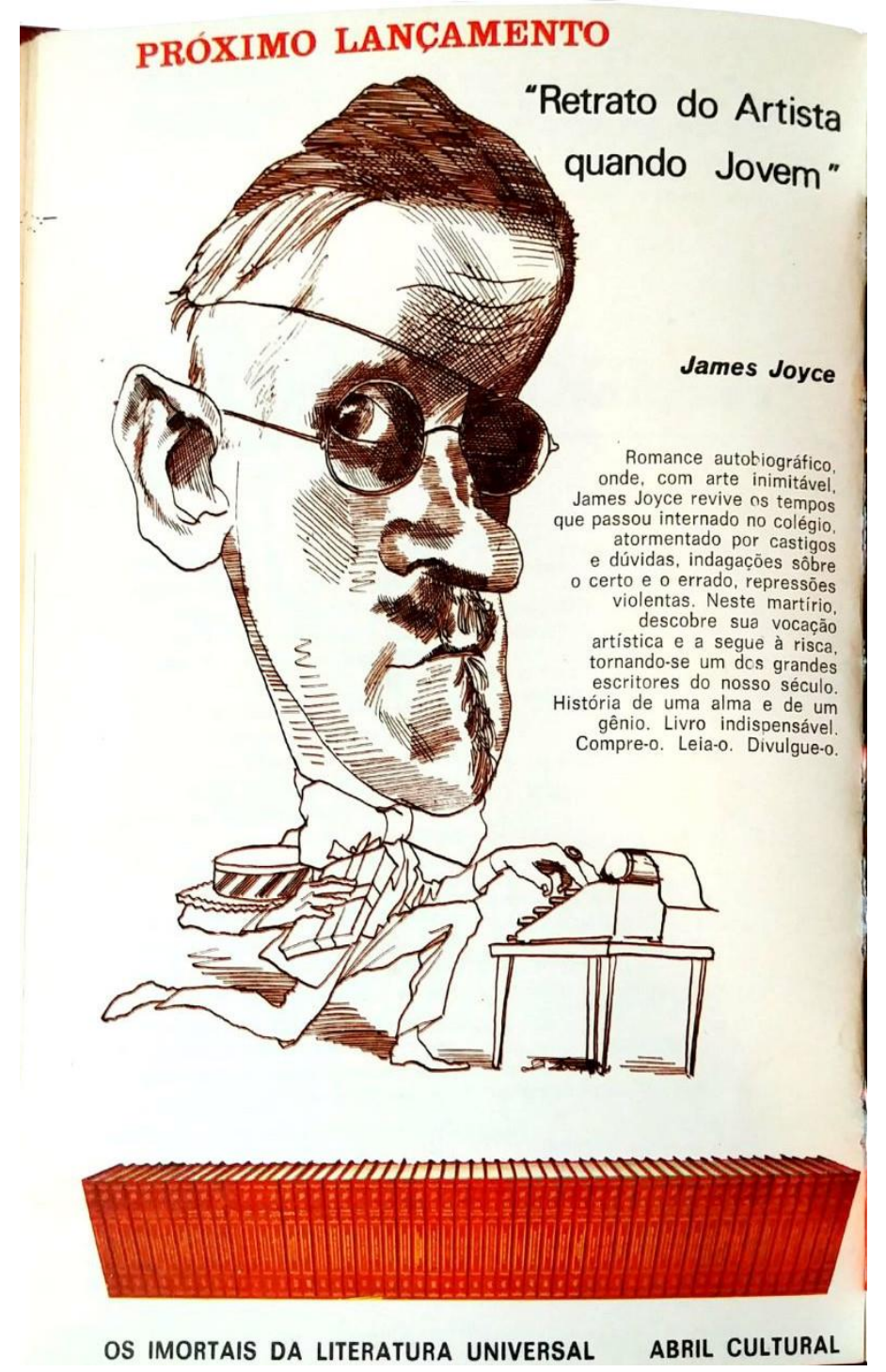

Fonte: acervo pessoal do autor.

A coleção Os Imortais da Literatura Universal encerrou seu ciclo após 100 semanas e 50 livros publicados. Com os fascículos reunidos, os colecionadores puderam formar mais três volumes de biografias, sendo o primeiro composto pelas biografias de: Bocaccio; Cervantes; Fielding; Goethe; E. Brontë; Balzac; Dickens; Dumas; Flaubert; Dostoiévski; Turgueniev; Machado de Assis; Conrad; Joyce; Colette; Thomas Mann; e Hemingway. O segundo volume trouxe: Defoe; Swift; Laclos; Stendhal, Manzoni; Victor Hugo; Eça de Queirós; Tolstói; Hardy; Lawrence; Fitzgerald; Gide; Kazantzakis; Huxley; Maugham; Steinbeck e Sartre. O volume final apresentou as biografias de: Voltaire; Walter Scott; Gógol; Melville; Oscar Wilde; Zola; James; Virginia Woolf; Pirandello; Malaparte; Lewis; Camus, Malraux; Moravia; 
Greene; e Jorge Luis Borges. A vendagem foi de incríveis 5 milhões de exemplares entre os 50 volumes, média de 100mil por título. Apenas da primeira obra, Os Irmãos Karamazov, de Dostoiévski, foram comercializadas 200 mil unidades ${ }^{26}$, o que a fez figurar na lista dos livros mais vendidos de 1971, à frente do best-seller Love Story, de Erich Segal, que vendeu 175 mil unidades naquele ano (BETTING, 1972).

\subsection{Os Pensadores: ou sobre como transformar clássicos da filosofia em best- sellers}

Em 1972, a Editora Abril havia avançado significativamente no mercado de livros completos. Desde a publicação de Papillon, primeiro livro comercializado em bancas, e "Imortais da Literatura Universal", algumas outras coleções de livros foram publicadas. Em dezembro de 1971, a Editora lançou Clássicos da Literatura Juvenil, uma série quinzenal - a primeira sem o acompanhamento de fascículos - com obras clássicas de literatura estrangeira, ilustradas e direcionadas ao público jovem, algumas adaptadas ou recontadas. Os exemplares eram vendidos em embalagens plásticas transparentes, onde um selo prateado com letras pretas era colado, informando, junto ao preço, que os títulos sairiam quinzenalmente, às terças-feiras. Dos 29 volumes que inicialmente a comporiam, a coleção foi finalizada com 50 , provavelmente devido à boa aceitação dos leitores.

Para o mesmo público, mas com histórias de ação e mistério originais e em texto integral, saiu, em julho de 1972, Os Hardy Boys, na Coleção Jovem Detetives, baseada na série de romances atribuídos a Franklin W. Dixon ${ }^{27}$, pseudônimo pelo qual diversos autores escreveram as aventuras dos irmãos Frank e Joe Hardy. Em dezembro seria lançada a coleção de livros Policiais Abril, que se dividia em duas séries: Aço, para romances de espionagem, e Bronze, para romances de detetive. Em pequeno formato $(18 \mathrm{~cm} \times 11 \mathrm{~cm})$ e papel de baixo custo e qualidade, devido ao fraco volume de vendas, foi a primeira e única iniciativa da

26190.300 exemplares. In: A OCUPAÇÃO das estantes. Veja, São Paulo, 24 out. 1973, p. 95. Disponível em:<https://acervo.veja.abril.com.br>. Acesso em: 15 mar. 2017.

27 Franklin W. Dixon foi o nome criado pelo Stratemeyer Literary Syndicate, empresa fundada pelo editor estadunidense Edward Stratemeyer em 1906, sob o qual diversos autores escreveram várias séries de histórias juvenis. Para mais detalhes sobre o autor e a série, consultar os verbetes "Edward Stratemeyer" e "Hardy Boys" da Enciclopédia Britannica, disponível em www.britannica.com. 
Editora em explorar um filão de muito sucesso nas bancas, o de romances policiais e de suspense.

O começo da década de 1970 foi um período de importante crescimento para o país, não apenas econômico, mas também editorial. Conforme Paixão (1997, p. 143) "entre 1969 e 1973 a produção anual de livros triplicou, colocando o Brasil no ranking dos dez maiores produtores do mundo", ainda que mais da metade do mercado fosse representada por obras didáticas. Em 1972, a produção de livros no país foi de aproximadamente 136 milhões de exemplares ${ }^{28}$, cerca de $40 \%$ maior que no ano anterior, que registrou a impressão de 80 milhões de exemplares ${ }^{29}$ (HALLEWELL, 2005, p. 601). Esse boom editorial provocou o aumento do número de editoras e acirrou a concorrência no mercado. Em 1972, a Abril viu surgir sua maior rival no comércio de fascículos em bancas de jornais: a Editora Três.

Fundada em fevereiro de 1972 por Domingo Alzugaray, Luis Carta e Fabrizio Fasano, ex-funcionários da Abril, a nova editora investiu de forma agressiva no mercado de fascículos, lançando diversas coleções, com a política de manter quatro sendo publicadas concomitantemente. No segmento dos livros vendidos em bancas, a Três, já em seu primeiro ano de existência, publicou, em 50 volumes, com capa dura marrom e gravação a ouro, sem acompanhamento de fascículos, a coleção Obras Imortais da Nossa Literatura. Formada por romances, novelas e contos clássicos da literatura brasileira e portuguesa, foi uma espécie de resposta, talvez provocação, aos "Imortais da Literatura Universal” da Abril, ainda não concluída, que, como informado, trouxe em seu catálogo apenas dois autores de língua portuguesa (Machado de Assis e Eça de Queirós).

Além de um recado, Obras Imortais da Nossa Literatura foi uma publicação de oportunidade da Três para não concorrer com a mesma proposta ou ser acusada de plágio. Distribuída pela Fernando Chinaglia, que havia trabalhado com a Abril no início de suas atividades no Brasil, a coleção obteve boa vendagem e foi reeditada dois anos depois, em 1974. Ainda em 1972, a Editora Três investe em livros policiais com a série Super Clube do Crime, publicação quinzenal lançada em dezembro, mesmo mês em que chegaram às bancas os Policiais Abril. Com o mesmo formato e

28136.026 .164

2980.194 .477$. 
miolo em papel de baixo custo, o preço de capa, no entanto, era de Cr\$4, superior aos $\operatorname{Cr} \$ 3,50$ cobrados pela Abril em sua coleção.

Antes comandando praticamente sozinha seu segmento, por conta da concorrência, a Abril foi obrigada a procurar maneiras de diversificar os lançamentos, sejam em fascículos ou livros completos, através da busca por temáticas ainda não saturadas e que pudessem despertar o interesse do público. Não há dúvidas de que os sucessos de Papillon e Os Imortais da Literatura Universal deram à editora a confiança de que havia encontrado um caminho lucrativo dentro do mercado de bens culturais no Brasil. E essa certeza, junto à necessidade de inovação, permitiu e incentivou o investimento em um projeto tão audacioso quanto arriscado como Os Pensadores, o empreendimento mais ousado da Abril Cultural no que tange à publicação de livros em coleções comercializadas em bancas de jornais.

Seja pelo ineditismo de alguns textos em língua portuguesa, pelo formato, pela qualidade das traduções ou pela competente equipe de tradutores de algumas das obras, a coleção, ainda que não tenha sido a de maior vendagem, é a que mais impacto teve, sob a perspectiva da disponibilização de textos de alta erudição e cunho acadêmico ao grande público, em pontos de venda até então incomuns a este tipo de produto cultural. Conforme Roberto Civita (1973), ao apresentar a coleção fora do Brasil, todos the disseram que estava louco, pois a venda de livros como esses não seria possível em nenhum lugar no mundo, seja Inglaterra, Estados Unidos ou Rússia, menos ainda no Brasil.

Antes da Abril, a Editora Vechi, do Rio de Janeiro, lançou, nos anos 1940, uma coleção de livros com um nome semelhante, "Os Grandes Pensadores", que foi, no entanto, comercializada em livrarias e sem a tiragem e o acabamento apresentados pelos Civita. Bem antes desta, a tradicional Laemmert, uma das mais antigas casas editoriais do Brasil, publicou no Brasil sua Bibliotheca Philosophica pelo menos desde o final do século XIX ${ }^{30}$. Também na década de 1940, a paulista Edições e Publicações do Brasil lançou "As Grandes Obras da Filosofia". Outras editoras difundiram obras de filosofia traduzidas para o português, como parte de outras coleções e temas, sem grande destaque.

30 Provavelmente a partir da década de 1890, conforme registros na Hemeroteca Digital da Biblioteca Nacional - RJ. 
Os Pensadores, que levou o subtítulo de "História das Grandes Idéias do Mundo Ocidental", chegou às bancas de jornais dos Estados do Rio de Janeiro, Guanabara e São Paulo no dia 09 de novembro de 1972, uma quinta-feira, dando sequência a "Imortais da Literatura Universal" no que tange à publicação de livros considerados eruditos, sob o ponto de vista da crítica especializada. O projeto da coleção demandou um investimento de quatro milhões de cruzeiros e a formação de uma equipe especializada no assunto (muitos dos quais professores universitários exonerados do funcionalismo público pelo golpe de 1964), que realizou uma investigação sobre tudo o que havia sido publicado no campo da filosofia no Brasil (A GRANDE..., 1972), de maneira que se formasse um conjunto de obras não concebido por reedições de livros anteriormente publicados por outras casas editoriais, como ocorreu em Os Imortais da Literatura Universal, mas títulos em boa parte inéditos no país e em língua portuguesa.

Formado por 50 livros com textos de 109 autores diferentes, o catálogo da coleção (Anexo II) é constituído por filósofos e também grandes nomes muitas vezes mais associados por leitores não especializados às ciências exatas, como Giordano Bruno, Galileu Galilei e Isaac Newton. Assim como em Imortais da Literatura Universal, o Oriente foi ignorado e a série concentrou-se apenas na reunião de autores associados ao Ocidente. Sobre seu plano editorial, nota-se, ao analisar a lista das obras, que foi feita uma distribuição obedecendo à seguinte proporção, em relação aos períodos históricos ${ }^{31}$ :

1) Antiguidade (Até séc. V): 6 livros - 24 autores;

2) Medievalidade (Sécs. V-XIV): 2 Livros - 5 autores;

3) Modernidade (Sécs. XV- XIX): 25 livros - 39 autores;

4) Contemporaneidade (Séc. XX - Atualidade): 18 livros - 40 autores.

31 A classificação histórico-filosófica que se realiza tem por objetivo facilitar a visualização, no espaço temporal, da distribuição dos livros e autores que compõem o catálogo. As divisões de escolas filosóficas e históricas são imprecisas, pois muitos autores apresentam características que os inserem em diferentes categorizações ou antecipam conceitos que são base de outras escolas e períodos. Reale e Antiseri (2003) demonstram, por exemplo, que Santo Agostinho possui atributos do pensamento escolástico medieval, embora o classifiquem na antiguidade tardia, assim como o humanismo-renascentista, associado aos séculos XIV e XV, possui raízes no século V e VI. Alertase, portanto, que a opção que se efetivou tem fins mais didáticos do que pretensão de sistematização. 
A distribuição de livros e autores no catálogo da Coleção deixa claro que, dentro dos objetivos que se espera de uma coleção para o grande público, Os Pensadores é formada por uma extensa quantidade de autores importantes para a história da filosofia e mostra-se bem-sucedida ao cobrir de forma ampla toda a produção do gênero ao longo do tempo e retratar boa parte das escolas filosóficas. O colecionador que completasse a série estaria munido de uma importante biblioteca de textos filosóficos, antes acessíveis apenas em edições em língua estrangeira ou publicações mais caras e de distribuição restrita. Certamente, pode-se discordar de algumas escolhas feitas pelo professor José Américo da Mota Pessanha e sua equipe, responsáveis pela formação do catálogo, entre as quais cita-se a ausência de autores e textos considerados fundamentais, assim como a concentração em temas ou fases de escolas e filósofos específicos; mas, de uma maneira geral, as principais obras da filosofia produzidas da Antiguidade até o início da década de 1970 estão presentes na Coleção. Severino (2009, p. 56-57) indica que, entre os muitos textos clássicos de filosofia traduzidos nos últimos anos, a coleção Os Pensadores, da Abril, merece destaque "pela abrangência dos textos traduzidos, pela qualidade da tradução e pela apresentação das obras".

Uma das lacunas é a ausência de autores da primeira fase da Idade Média, conhecida também como Alta Idade Média. Neste período, os pensadores de maior destaque, Boécio (480 - 524) e João Escoto Eriúgena (ca.810 - ca.870), foram ignorados, ainda que o catálogo aborde de maneira satisfatória alguns dos principais pensadores do período medieval. A opção por não apresentar autores importantes do alto medievo resulta em um lapso mais de 500 anos entre o livro dedicado à Santo Agostinho e o volume com os textos de Santo Anselmo e Pedro Abelardo, reforçando a equivocada visão de um período de "trevas" no pensamento ocidental entre a Antiguidade e Ano Mil.

As traduções apresentadas são provenientes de direitos adquiridos ou versões originais feitas pela equipe de tradutores que trabalhou exclusivamente para a Coleção. Nos volumes com coletâneas de textos de um autor, é comum aparecerem juntas traduções feitas pela Abril e outras com direitos cedidos. Entre os tradutores contratados pela Editora estavam profissionais que, além de verterem os textos em língua estrangeira para o português, eram especialistas nos autores em que trabalharam, como é o caso de Marilena Chauí (Baruch Espinoza) e José Arthur 
Gianotti (Karl Marx). Entre a equipe de tradutores, estava também Fernando Henrique Cardoso, aposentado compulsoriamente, em 1969, pelo Regime Militar, da Universidade de São Paulo, na qual era professor concursado, e que seria presidente do país duas décadas depois.

Em alguns números, além da transposição, os tradutores eram responsáveis pela seleção dos textos. Gianotti esclareceu, em artigo publicado à época do lançamento do livro sobre Marx, os critérios de escolha e tradução, informando que, devido à opção da Editora por publicar textos completos, procurou "[...] tomar alguns exemplos que pudessem frisar os momentos mais decisivos da trajetória intelectual daquele autor":

\begin{abstract}
O Terceiro Manuscrito de 1844 recorda sua filiação a Feuerbach, mostrando ao mesmo tempo como seu projeto de crítica à Economia Política, preocupação constante de toda sua vida, se faz, desde os tempos de sua juventude, a partir da problemática do trabalho. As Teses contra Feuerbach configuram o momento de sua ruptura com sua consciência filosófica, apontando, ademais, para a nova filosofia da práxis. Salário, Preço e Lucro dá uma visão geral de sua doutrina econômica, assim como tira suas consequências políticas mais imediatas. Aproveitar a tradução de Elias Chaves foi um modo de prestar homenagem àqueles que, em condições tão adversas, lograram divulgar o pensamento de Marx entre nós. Para a Crítica da Economia Política representa, sem dúvida, o primeiro resultado da aliança entre Dialética e Economia Política. A fim de salientar a importância filosófica desse escrito foi necessário cuidar para que o vocabulário do idealismo alemão pudesse transparecer na sua versão portuguesa. Este imenso trabalho foi realizado sobretudo por Edgar Malagodi, resumindo-se minha função a indicar os termos que já possuíam tradução corrente. Por isso, numa próxima edição, seu nome deverá figurar em primeiro lugar, corrigindo assim uma injustiça que involuntariamente foi cometida, quando, em lugar do seu, meu nome foi posto em evidência. Para apresentar um texto fiel e ao mesmo tempo fluente de O Rendimento e suas Fontes, um dos melhores exemplos do que possa vir a ser uma análise de ideologia, Walter Rehfeld e eu tivemos um trabalho insano. Como traduzir corretamente um conjunto de notas rápidas, muitas vezes incompletas, mantendo-se, todavia, rente ao texto? Finalmente, foi incluído 018 do Brumário de Luís Bonaparte, na cuidada tradução revista por Leandro Konder, para exemplificar a fertilidade da dialética marxista ao analisar uma conjuntura política. Não é porque o texto foi publicado em Nova York que o original tenha sido escrito em inglês, como infelizmente consta da edição. Este engano, dentre outros, deve futuramente ser corrigido. No entanto, a despeito de todas as imperfeições, é preciso não diminuir o mérito da Editora Abril que teve a coragem de publicar uma seleção de textos de Marx numa edição que, embora popular, procurou respeitar as exigências acadêmicas (FILÓSOFOS..., 1974, p. 23).
\end{abstract}

O excerto mostra, de maneira privilegiada, o rigor adotado por um dos profissionais contratados pela editora e seus colaboradores. A seleção dos textos foi feita de maneira estratégica para situar o leitor em diferentes momentos do pensamento marxista, permitindo a avaliação do desenvolvimento das posições 
políticas e teóricas no decorrer de da vida de Marx. Os tradutores preocuparam-se em fazer refletir a linguagem do idealismo alemão na versão de Para a Crítica da Economia Política e os vocábulos foram cuidadosamente selecionados respeitandose a semântica dos termos originais, da mesma forma que foi vencido o desafio da complexidade de se traduzir breves notas de Marx escritas em alemão. Gianotti também demonstra os erros a que estão sujeitos trabalhos desse porte, como a indicação, na folha de créditos, de um original em inglês que, na verdade, foi produzido em alemão.

O cuidado com que os textos foram selecionados ou traduzidos comprova que os editores se preocuparam efetivamente em entregar uma coleção de alta qualidade e respeitando o rigor acadêmico, embora os livros fossem populares, ao menos no que tange à sua ampla tiragem e comercialização. A escolha por este caminho editorial permite que se considere a coleção Os Pensadores como um produto destinado a capitalizar a Abril não apenas economicamente, mas também simbolicamente, como uma empresa preocupada com seus produtos editoriais, principalmente após as críticas a alguns equívocos cometidos em Os Imortais da Literatura Universal. A escolha da temática foi importante para que se alcançasse um público consumidor diferente, constituído principalmente por estudantes universitários e profissionais com maior grau de educação formal.

No aspecto da materialidade, Os Pensadores foi publicada em volumes de capa dura em tom azul, tamanho 18 por $25 \mathrm{~cm}$ com o livro fechado. A gravação em hot stamping foi produzida em cor dourada, exibindo arabescos semelhantes aos de Os Imortais da Literatura Universal, porém mais sóbrios, sem flores e folhas em forma concreta, utilizando representações de linhas abstratas que se unem e se intercalam produzindo uma moldura que envolve e enquadra o título da coleção e o nome da Editora, posicionados no ponto central da capa (Fig. Figura 30).

O material adotado é o mesmo utilizado em Os Imortais...: um acartonado recoberto por lâminas vinílicas de textura emborrachada, que remetem à aparência do couro e se estendem por cerca de $0,5 \mathrm{~cm}$ para as guardas, formando a seixa. Os cabeceados eram compostos por tiras de tecido alternando as cores azul e branca. A lombada apresenta uma série de oito linhas de arabescos, que separam os elementos de identificação da obra: no alto, seu título e número de sua localização na coleção, escrito em algarismos romanos; ao centro, o nome do autor ou dos 
autores, em caso de coletânea, sem o acompanhamento do título do(s) texto(s); no segmento inferior, o logotipo da Abril Cultural (Fig. Figura 30). O tamanho das folhas do miolo é de 16,5 por $24 \mathrm{~cm}$, formato $38 \%$ maior que o de "Imortais da Literatura Universal", mas de grande aproveitamento da folha de impressão e, consequentemente, custo otimizado, evitando-se desperdícios.

Figura 30 - Capa e lombada de um volume da coleção

Os Pensadores

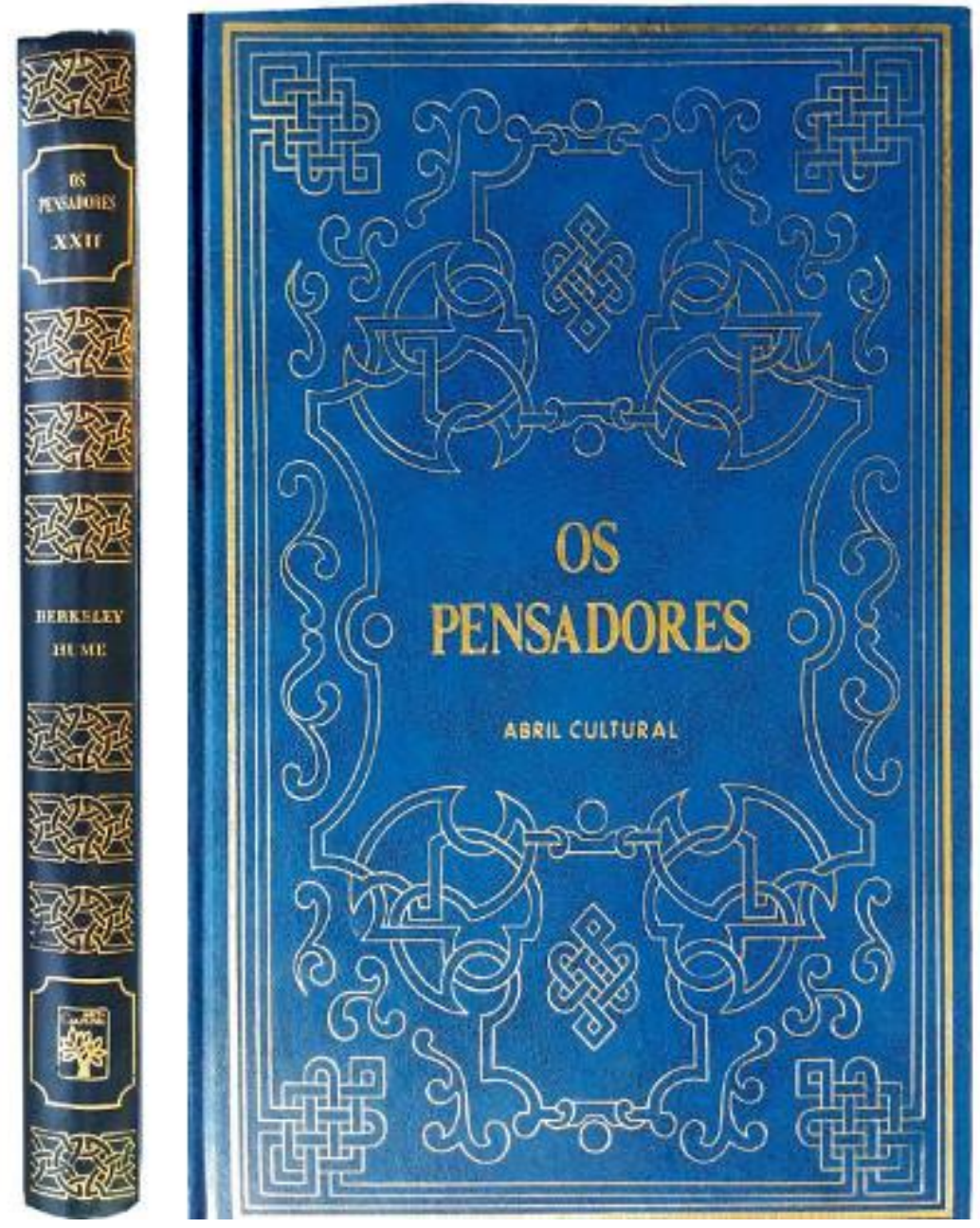

Fonte: acervo particular do autor.

O primeiro exemplar a ser analisado é o volume III da coleção, dedicado a Platão, em que constam seus diálogos ( $O$ Banquete, Fédon, Sofista, Político) em tradução direta do grego. O Banquete foi traduzido por José Cavalcante de Souza e publicado originalmente no Brasil pela Difusão Europeia do Livro, em 1966, na sua coleção Pequena Biblioteca Difel. Os outros três diálogos foram traduzidos por Jorge Paleikat e João Cruz Costa, publicados pela primeira vez em 1945 pela Editora 
Globo de Porto Alegre, na coleção Biblioteca dos Séculos. O volume possui 272 páginas, numeradas de 10 a 269 na parte superior direita das folhas, que, junto às capas, resultam em uma espessura de $2 \mathrm{~cm}$. A falsa folha de rosto conta apenas com o nome da coleção, em caixa alta e tipografia que simula letras em relevo, seguido pelo número da coleção logo abaixo (Fig. Figura 31). A folha de rosto é esteticamente melhor composta que em Os Imortais da Literatura Universal, embora o símbolo da editora e o ano de publicação pudessem estar posicionados na parte inferior, junto ao nome do editor (Victor Civita), ao invés de apresentarem-se separados e deslocados, ocupando um espaço em branco no segmento inferior da página (Fig. Figura 31). A folha de rosto e a falsa folha de rosto seguem o mesmo padrão em outros exemplares, exceto pela indicação do ano de publicação, que está ausente em alguns volumes.

Figura 31 - Falsa folha de rosto e folha de rosto em Os Pensadores

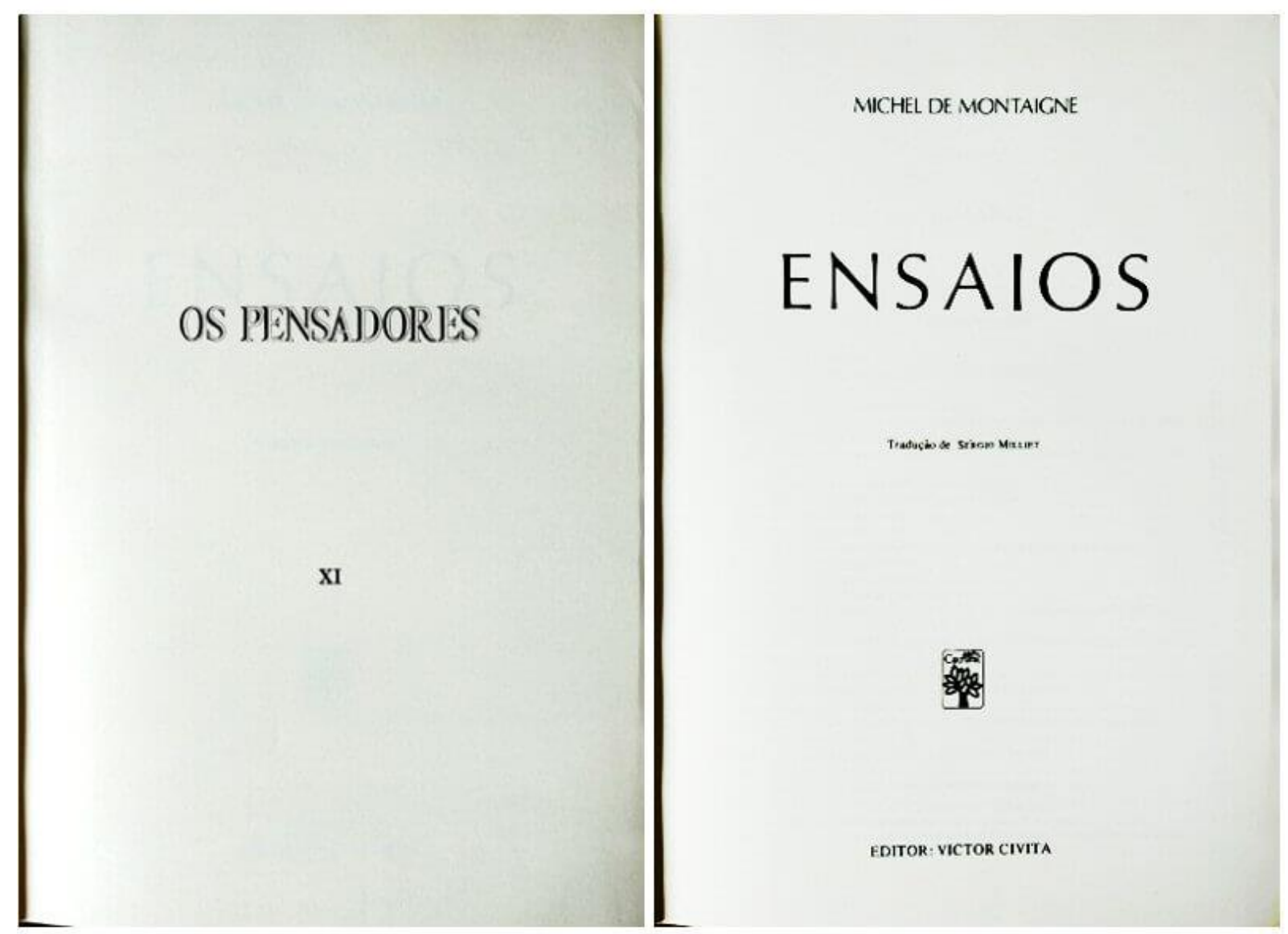

Fonte: acervo particular do autor. 
Os Pensadores tem seus textos dispostos em duas colunas e a Abril divulgou ao público, nas peças publicitárias, que os livros da coleção seriam impressos dessa maneira para facilitar a leitura. De fato, a maioria dos volumes apresenta as colunas duplas, mas, em pelo menos um dos consultados, o texto é composto em coluna simples (vol. XXII, dedicado a Berkeley e Hume, abordado logo abaixo). O volume que reúne textos de Platão possui o recurso de notas críticas laterais que facilitam a identificação pelo leitor do fragmento de texto a que se referem as notas de rodapé. As margens laterais sofrem menos variações que em Os Imortais...: as externas e internas possuem entre $1,5 \mathrm{~cm}$ e $1,8 \mathrm{~cm}$, enquanto as superiores e inferiores contam com maior variação, entre $1,3 \mathrm{~cm}$ a $2 \mathrm{~cm}$. O tamanho do intervalo entre as colunas está padronizado ao longo dos textos em $0,5 \mathrm{~cm}$, com raros momentos em que uma coluna apresenta leve inclinação, onde se pode medir o desnível do espaço interno. O entrelinhamento é adequado, maior que o tamanho da fonte utilizada, o que torna mais fácil a localização das linhas de texto. A mancha tipográfica possui $13 \mathrm{~cm}$ de largura (15 cm se consideradas as notas laterais) e 20,6 cm de altura.

Como padrão da coleção, a composição é feita em fonte serifada, que oferece os benefícios já apontados em relação à ergonomia da leitura, com exceção do nome do autor, título e editor na folha de rosto, bem como o tipo especial utilizado na falsa folha de rosto. Ao topo da mancha, as páginas pares (à esquerda) informam o nome do autor em caixa alta, e as páginas ímpares (à direita), o nome do texto, também em caixa alta. O colofão, em quatro linhas na parte inferior da última página do miolo, não numerada, informa que "Este livro integra a coleção" / "OS PENSADORES - HISTÓRIA DAS GRANDES IDEIAS DO MUNDO OCIDENTAL" I "Composto e impresso nas oficinas da" / "Abril S. A. Cultural e Industrial, caixa postal 2372, São Paulo".

O segundo volume a ser avaliado é o décimo sexto da coleção, que contém os Pensamentos de Blaise Pascal, traduzido do original francês por Sérgio Milliet e publicado inicialmente pela Difusão Europeia do Livro (DIFEL) em 1957, inaugurando a coleção Clássicos Garnier. Sobre essa tradução, há um plágio de Sérgio Milliet identificado por Paulo Rónai e divulgado pela tradutora Denise Bottmann em seu blog ${ }^{32}$, em que trechos inteiros da versão de Paulo M. Oliveira

32 Disponível em: <http://naogostodeplagio.blogspot.com.br/2012/12/sergio-milliet-que-coisa.html>. Acesso em 28 jun 2017. 
(pseudônimo de Aristides Lobo) para a Editora Athena, publicada em 1936, foram copiados. O exemplar conta com uma introdução de Charles-Marc Des Granges, especialista em literatura francesa, e uma biografia de Pascal escrita por sua irmã, Françoise Gilberte Périer. Possui ainda notas do tradutor e do editor, Prof. Vitor Ramos, responsável pela edição da DIFEL. Contém 282 páginas, numeradas de 8 a 280 , resultando, junto às capas, em 2,1 cm de espessura.

O texto foi impresso no mesmo padrão de fonte serifada de toda a Coleção, composto em duas colunas. O corpo do tipo é maior em número dedicado à Platão, com espacejamento entrelinhas adequado. As margens estão dispostas da seguinte maneira: a externa varia entre $1,6 \mathrm{~cm}$ e $2 \mathrm{~cm}$; a interna entre $1,5 \mathrm{~cm}$ e $1,8 \mathrm{~cm}$; a superior entre $1,1 \mathrm{~cm}$ e $1,7 \mathrm{~cm}$; a inferior entre $1,3 \mathrm{~cm}$ e $1,8 \mathrm{~cm}$. A mancha tipográfica possui $13 \mathrm{~cm}$ de largura e entre $20,6 \mathrm{~cm}$ e $20,8 \mathrm{~cm}$ de altura, e o espaçamento entre as colunas varia entre $0,4 \mathrm{~cm}$ e $0,6 \mathrm{~cm}$. Ao final do livro, um índice aponta para os diversos artigos do texto.

O volume inclui ainda uma pequena errata, feita no mesmo papel do miolo, em formato $7 \mathrm{~cm}$ por $12 \mathrm{~cm}$, onde se informa que o número anterior, dedicado a Montesquieu, foi impresso sem a indicação de autoria da introdução e das notas, sob responsabilidade de Gonzague Truc, bem como da tradução, feita por Fernando Henrique Cardoso e Leôncio Martins Rodrigues. Um detalhe interessante, perceptível ao se analisar a guarda da capa, é a presença de uma pequena inscrição, feita manualmente à caneta esferográfica, da palavra "cola" (Fig. Figura 32), provavelmente uma indicação ao encadernador de que ali deveria ser inserida a cola para a encadernação do miolo. 
Figura 32 - Detalhe da primeira contracapa do volume dedicado a Pascal, onde se lê "cola".

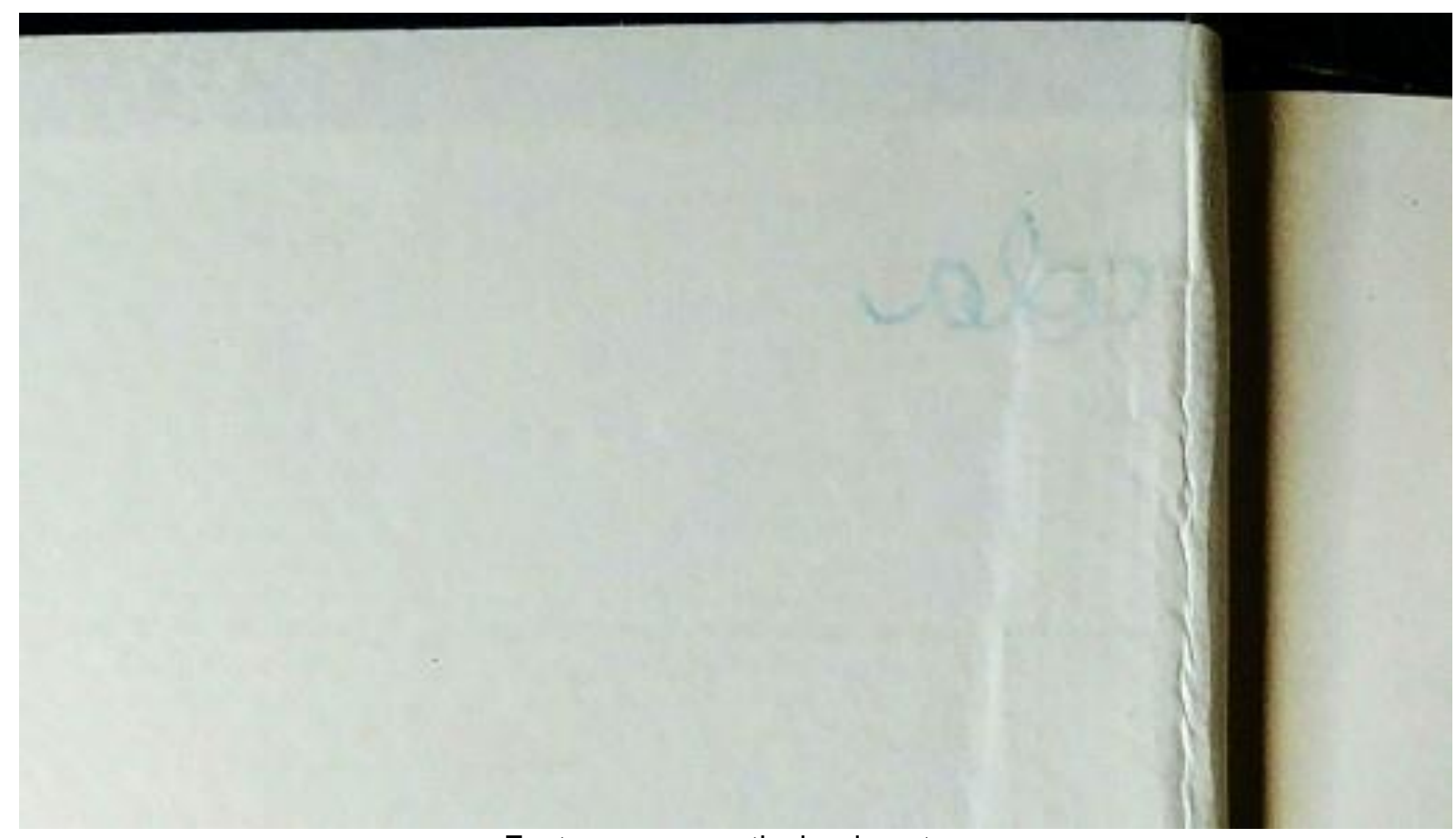

Fonte: acervo particular do autor.

O terceiro exemplar a ser estudado, dedicado a George Berkeley e David Hume, é o vigésimo segundo publicado na coleção. De Berkeley, estão incluídos os textos Tratado sobre os Princípios do Conhecimento Humano e Três Diálogos entre Hilas e Filonous em Oposição aos Céticos e Ateus, traduzidos por Antônio Sérgio e publicados a princípio pela Editora Atlântida, de Coimbra, Portugal. Os diálogos de Berkeley foram lançados originalmente com introdução e notas do tradutor, complementos que não foram utilizadas na edição de Os Pensadores, enquanto o Tratado... apresenta as notas de Antônio Sérgio, conforme a edição da Atlântida. De autoria de Hume, estão inclusos os textos Investigação sobre o Entendimento Humano, traduzido por Leonel Vallandro, com direitos cedidos pela Editora Globo de Porto Alegre, aparentemente sem publicação anterior pela editora gaúcha, e Ensaios Morais, Políticos e Literários, em tradução de João Paulo Gomes Monteiro e Armando Mora de Oliveira, feita com exclusividade para a Coleção. Monteiro, português radicado no Brasil, foi um dos maiores especialistas em Hume do país.

O volume se distingue dos outros analisados principalmente pela composição do texto, feita em coluna simples, embora, no plano da coleção, divulgado em suas peças publicitárias, a Abril tenha informado que os textos dos livros seriam divididos em duas colunas, para facilitar a leitura. Possui 330 páginas, numeradas de 12 a 
325 , resultando, junto às capas, em $2,6 \mathrm{~cm}$ de espessura. A fonte, serifada, é de corpo pequeno, mas há entrelinhamento adequado e a mancha tipográfica possui $13 \mathrm{~cm}$ de largura, sem variações, e de $19 \mathrm{~cm}$ a 19,7 cm de altura. As margens são constituídas conforme os valores a seguir: a externa varia entre $1,7 \mathrm{~cm}$ e 2,3 cm; a interna entre $1,4 \mathrm{~cm}$ e $1,6 \mathrm{~cm}$; a superior entre $1,3 \mathrm{~cm}$ e $1,6 \mathrm{~cm}$; a inferior entre $1,2 \mathrm{~cm}$ e $1,4 \mathrm{~cm}$. Conta com um índice no final do livro remetendo às partes presentes nos textos de cada autor.

Em Os Pensadores, as indicações de ano de publicação não coincidem com o período em que, de fato, as obras foram disponibilizadas em bancas. Volumes publicados no começo da coleção, no final de 1972, traziam data da edição de 1973, da mesma forma que o volume final informa 75, enquanto há indício de que a coleção tenha atrasado seu cronograma, tendo o penúltimo número sido comercializado em 1976, conforme carta de um colecionador do Rio de Janeiro para o Jornal do Brasil em julho de $1976^{33}$. Provavelmente a Editora planejou a coleção com uma ordenação e a alterou devido a opções comerciais ou industriais. Diferentemente do ocorrido em Os Imortais da Literatura Universal, não foram identificadas variações no papel utilizado durante a impressão dos volumes da coleção.

Cada exemplar veio acompanhado de um fascículo colorido, em papel couchê brilhante, com 20 páginas que formavam os capítulos a serem encadernados, totalizando 4 volumes com as biografias, cronologia e bibliografia utilizada para produção de cada fascículo. Observa-se que, diferente de Os Imortais da Literatura Universal, a cronologia foi colocada junto ao conteúdo encadernável do fascículo, corrigindo o equívoco da coleção anterior. Entretanto, manteve-se o erro de editar os fascículos no mesmo formato que a capa dos livros, obrigando o encadernador a refilá-los, o que não ocorreria se tivessem sido impressos com o tamanho idêntico ao do miolo.

Após 52 volumes lançados quinzenalmente nas bancas, Os Pensadores foi concluída, obtendo níveis de venda extraordinários para obras de filosofia, a maioria herméticas ao grande público, e com textos seguindo os rigores acadêmicos de edição. Em reportagem de 1974 (FILÓSOFOS..., 1974, p. 23), quando a coleção já 
havia alcançado o número XXXVI, informou-se que "[...] os primeiros números divulgados pela Abril são surpreendentes": o volume dedicado à Platão havia atingido "[...] 112 mil exemplares. Montaigne, com 64 mil e Sócrates, com 55 vêm em seguida". Entre os oito volumes que tiveram seus dados de venda revelados até aquele momento, o menos comercializado havia sido Descartes, com 41 mil exemplares.

O bom nível de vendas da coleção fez com que fosse relançada diversas vezes: em 1975, reimpressa com o mesmo padrão formal; em 1979, organizada em 68 volumes no formato brochura, com capa cinza apresentando uma imagem do autor selecionado e mesmo tamanho da primeira edição; em 1983, em brochura de formato menor, já após a divisão da empresa entre os irmãos Civita; e outras cinco vezes pela Nova Cultural, que herdou o espólio da Abril Cultural após 1982. Não houve edições com capas diferenciadas para o sistema porta-a-porta, como em Os Imortais da Literatura Universal.

O preço de cada exemplar da coleção Os Pensadores, em formato grande e encadernação requintada, acompanhado de um fascículo, era inicialmente de 15 cruzeiros. Algumas das revistas mais populares do período, como Veja, O Cruzeiro e Manchete, custavam entre $\mathrm{CR} \$ 3,50$ e $\mathrm{CR} \$ 4,00$, o que tornava o valor dos exemplares da coleção, publicados quinzenalmente, não muito distantes aos de um semanário popular, enquanto um livro de tamanho convencional (260 páginas) de outras editoras custava, em média, CR $\$ 23,40$, conforme Hallewell (2005). Ainda que o preço de Os Pensadores fosse bastante atrativo, era muito mais caro que Romances Capricho, coleção de livros de bolso em brochura e papel de baixa qualidade comercializados a Cr\$1 (15 vezes menos) pela própria Abril no início dos anos 1970. Essa diferença não impediu, no entanto, que vendessem, conforme Roberto Civita (1973), mais que os romances baratos de Capricho, de que se esperava melhor volume. Civita preferiu não explicar o fenômeno, assumindo que não havia lógica no que se apresentava. Mas é possível considerar três questões que auxiliam na interpretação do fato:

1) Os Pensadores não tinham concorrência nas bancas. No período em que a coleção foi publicada, muitas editoras comercializavam livros baratos e populares como eram os Romances Capricho e até coleções de literatura de caráter clássico e erudito, como foi o caso da Três, mas nenhuma outra coleção de filosofia foi vendida 
em bancas de jornais nos anos 1970, principalmente com as características da edição da Abril Cultural.

2) Os Pensadores atingia uma faixa social que, embora menos numerosa, era dotada de maior poder de compra. Para este segmento da população, os livros vistos como muito populares não conservavam as propriedades necessárias para a distinção que almejavam, não sendo objetos de consumo conspícuo.

3) O mercado de livros acadêmicos de filosofia, em que também se inseria Os Pensadores, era limitado, e os valores de outras edições, quando disponíveis, eram altos em comparação aos da coleção da Abril, que foi adquirida, completa ou em parte, por estudantes de nível superior, principalmente dos cursos de Filosofia e de Ciências Humanas.

Estes fatores, associados, são uma possível explicação para o desequilíbrio no volume de vendas entre as duas publicações da Editora que, contemporâneas e de valores muito diferentes, possuíam públicos específicos e ofertas de produtos concorrentes distintas. Roberto Civita, devido a sua posição na empresa e como um editor capaz que foi, em seu discurso provavelmente ocultou da audiência, por questão estratégica, o profundo conhecimento que possuía sobre os diferentes consumidores de cada coleção.

O país, a Abril e o mercado de vendas de produtos culturais em bancas de jornais passaria por uma série de transformações até o lançamento da próxima coleção de livros, que completaria a tríade de publicações da Abril dedicada a três diferentes áreas das ciências humanas e das artes. Em Imortais da Literatura Universal, foi contemplada a literatura ocidental, da era moderna à contemporânea; Os Pensadores abordou a história da filosofia por meio de obras originais dos principais filósofos, desde a Antiguidade; e, finalmente, descerravam-se as cortinas para a estreia da última coleção relevante de livros completos e encadernados publicados pela Abril. Teatro Vivo apareceria em 1976, oferecendo ao público textos da milenar arte da representação.

\subsection{Teatro Vivo: o último grande espetáculo da década nas bancas de jornais}

Entre o processo de edição de Os Imortais da Literatura Universal (1970-72) e o lançamento de Os Pensadores (1972-73), o Brasil viveu os mais intensos anos do 
que se convencionou chamar de "Milagre Econômico Brasileiro" (1968 - 1973/74). A economia crescia a índices superiores a $10 \%$ ao ano, financiada pela massiva entrada de capital estrangeiro, devido a uma conjuntura externa favorável. Em outubro de 1973, a OPEP (Organização dos Países Produtores de Petróleo) decidiu reduzir a produção e elevar o preço do barril de petróleo, o que ocasionou um súbito aumento no preço dos produtos dele dependentes e gerou uma crise global que afetou as maiores economias já a partir de 1974. Diante de um cenário de incertezas e alta dos preços, os investimentos externos recrudesceram, obrigando o país a utilizar suas reservas e a voltar-se a novos investidores.

O efeito inflacionário da crise do petróleo produziu um aumento nos custos das empresas que dele dependiam como combustível ou matéria-prima, bem como tornou caro o valor da gasolina e do diesel, utilizados para transporte individual, coletivo e de cargas. A reação foi em cadeia e a inflação superou os 34\% em 1974 e os $46 \%$ em $1976^{34}$. O salto inflacionário tornou mais caro o crédito, base da grande demanda interna por produtos e serviços durante o "milagre", e as classes médias, antes silenciadas pelos benefícios provenientes da euforia econômica, sentiram o efeito da crise e da perda do poder aquisitivo. Assim, quando Os Pensadores terminou de ser publicada, entre 1975 e 1976, as condições do mercado eram diferentes daquelas experimentadas no começo da década. A concorrência de outras editoras no segmento de coleções fasciculares ampliava a necessidade de diversificação e o índice inflacionário já não permitia ao público os mesmos investimentos de antes, quando as classes médias tinham condições de fazer diversas coleções concomitantemente - uma leitora revelou em reportagem da época (RANGEL, 1974) já ter acompanhado oito coleções ao mesmo tempo. Em julho de 1974, Pedro Paulo Popovic, diretor da Divisão de Fascículos, informava que as 21 áreas em que o conhecimento humano havia sido dividido pela editora já haviam sido cobertas até aquele momento (RANGEL, 1974).

Embora a oferta de fascículos fosse grande, no segmento de livros prontos o volume de lançamentos era inferior, ainda que superior ao volume do ano de 1970, quando a Abril, sozinha, estampou nas bancas de todo o país Os Imortais da Literatura Universal, após o solitário teste de Papillon. Em 1973, foi publicada a

34 Índice IGP-DI - Fundação Getúlio Vargas, Conjuntura Econômica - IGP. Disponível em: $<$ http://www.ipeadata.gov.br/>. Acesso em: 23 nov. 2015. 
coleção Biblioteca das Crianças, pequenos livros ilustrados a cores, em capa dura e 34 páginas, abordando temas como "Eletricidade", "O Universo", "Navios Antigos", "Televisão", entre outros, explicados em textos curtos para o público infantil. No início de 1974, a Abril lançou mais uma coleção de livros de literatura completos, em capa dura, mas, ao contrário de Os Imortais..., a coleção Clássicos Modernos se dedicou a autores contemporâneos best-sellers, com obras em sua maioria publicadas originalmente entre os anos 1930 e 1960, algumas das quais, como Spartacus, de Howard Fast; Lolita, de Vladimir Nabokov; Zorba, o Grego, de Nikos Kazantzakis; e Grande Hotel, de Vicki Baum, já haviam sido adaptadas ao cinema com sucesso por grandes estúdios de Hollywood.

A Editora não apostaria em livros de maior formato e extensão após Clássicos Modernos, em parte pelo fato de a inflação ascendente tornar arriscado o empreendimento - com o aumento dos custos de produção, o preço dos exemplares poderia atingir valores altos, intimidando o público, já menos capitalizados que nos anos anteriores. A própria Abril sentira a crise pós-"milagre" e, em 1974, demitiu mais de 100 pessoas, o que fez ser criado, na redação da Abril Cultural, conforme Maranhão (2016, p. 111), o termo "passaralho"35, para definir uma demissão em massa, cuja representação era a figura de um "órgão sexual masculino com asinhas". Aqueles atingidos pelo "passaralho" estariam demitidos.

Em dezembro do mesmo ano, é publicada uma coleção de formato e dinâmica diferentes dos que a Editora vinha apresentando até então: Conte um Conto foi lançada quinzenalmente com quatro pequenos livros infantis por vez, dedicados a estimular os pais a lerem e encenarem as histórias junto a seus filhos. Em 1975, novamente chega às bancas um livro individual, fora de coleção, publicado pela Abril cinco anos após Papillon: Meu Primeiro Dicionário, um volume ilustrado de 60 páginas e capa dura com palavras comuns ao universo infantil e sua respectiva imagem em cada página.

Teatro Vivo seguiu a nova estratégia da Abril para formato de livros completos. A coleção chegou às bancas em 27 de abril de 1976, terça-feira, ao custo de Cr\$30 e tiragem inicial de 70 mil exemplares. Oferecia, junto ao volume inaugural, Hamlet, de William Shakespeare, um livro introdutório sobre a história do teatro, denominado 
Introdução e História, cujo objetivo era esclarecer ao leitor "[...] a evolução dos gêneros dramáticos, as bases da tragédia e da comédia, os métodos de interpretação, de direção, cenografia, figurinos e sobre a função social do teatro" ${ }^{36}$, além de informar sobre as montagens da peça em questão no Brasil e no mundo.

Antes, porém, no dia anterior, às $21 \mathrm{~h}$, foi veiculada em parceria com a TV Tupi de São Paulo e suas retransmissoras em todo o país provavelmente a maior peça publicitária para o lançamento de livros no Brasil: um programa especial, com duas horas de duração, escrito por Flávio Rangel e Millôr Fernandes e dirigida por Flávio Rangel, que reuniu um elenco com os maiores nomes da dramaturgia e da teledramaturgia daquele momento para encenarem 18 episódios baseados em importantes peças de teatro, desde o antigo até o contemporâneo. O Gesto, A Festa, A Mensagem: 2000 Anos de Teatro foi produzido pela agência paulista GANG responsável pela reestruturação da grade e por outras parcerias com a TV Tupi -, com patrocínio de Teatro Vivo (Fig. Figura 33), e contou com a participação de: Antunes Filho, Ariclê Perez, Bibi Ferreira, Beatriz Segall, Célia Helena, Carlos Zara, Cláudio Correa e Castro, Cleyde Yaconis, Dionisio de Azevedo, Edney Giovenazzi, Edwin Luisi, Elias Gleiser, Elis Regina, Etty Fraser, Eva Wilma, Ewerton de Castro, Felipe Carone, Fernanda Montenegro, Geraldo D'el Rei, Gianfrancesco Guarnieri, Henrique Martins, Joana Fomm, João José Pompeo, John Herbert, José Luis Pinho, Laerte Morrone, Maria Della Costa, Maria Isabel de Lisandra, Othon Bastos, Paulo Autran, Paulo Hesse, Raul Cortez, Ricardo Blat, Riva Nimitz, Rodolfo Mayer, Sadi Cabral, Tônia Carrero, Toni Ramos, Xandó Batista e Wanda Stefânia.

A transmissão foi um sucesso (A REDESCOBERTA, 1976) e o programa superou em audiência todas as outras emissoras, mesmo concorrendo com a novela O Grito, da Rede Globo, sendo, devido a isso, reapresentado às segundas-feiras, 22h30, de maneira fracionada, com 30 minutos de duração, pela Tupi.

36 Conforme propaganda veiculada no Jornal do Brasil em 11 de maio de 1976, Caderno B, p. 8. Disponível em: <http://memoria.bn.br/DocReader/030015 09/140343>. Acesso em: 23 jul 2017. 
Figura 33 - Indicação de patrocínio de Teatro Vivo na abertura e entre os intervalos comerciais do espetáculo O Gesto, A Festa, A Mensagem: 2000 Anos de Teatro
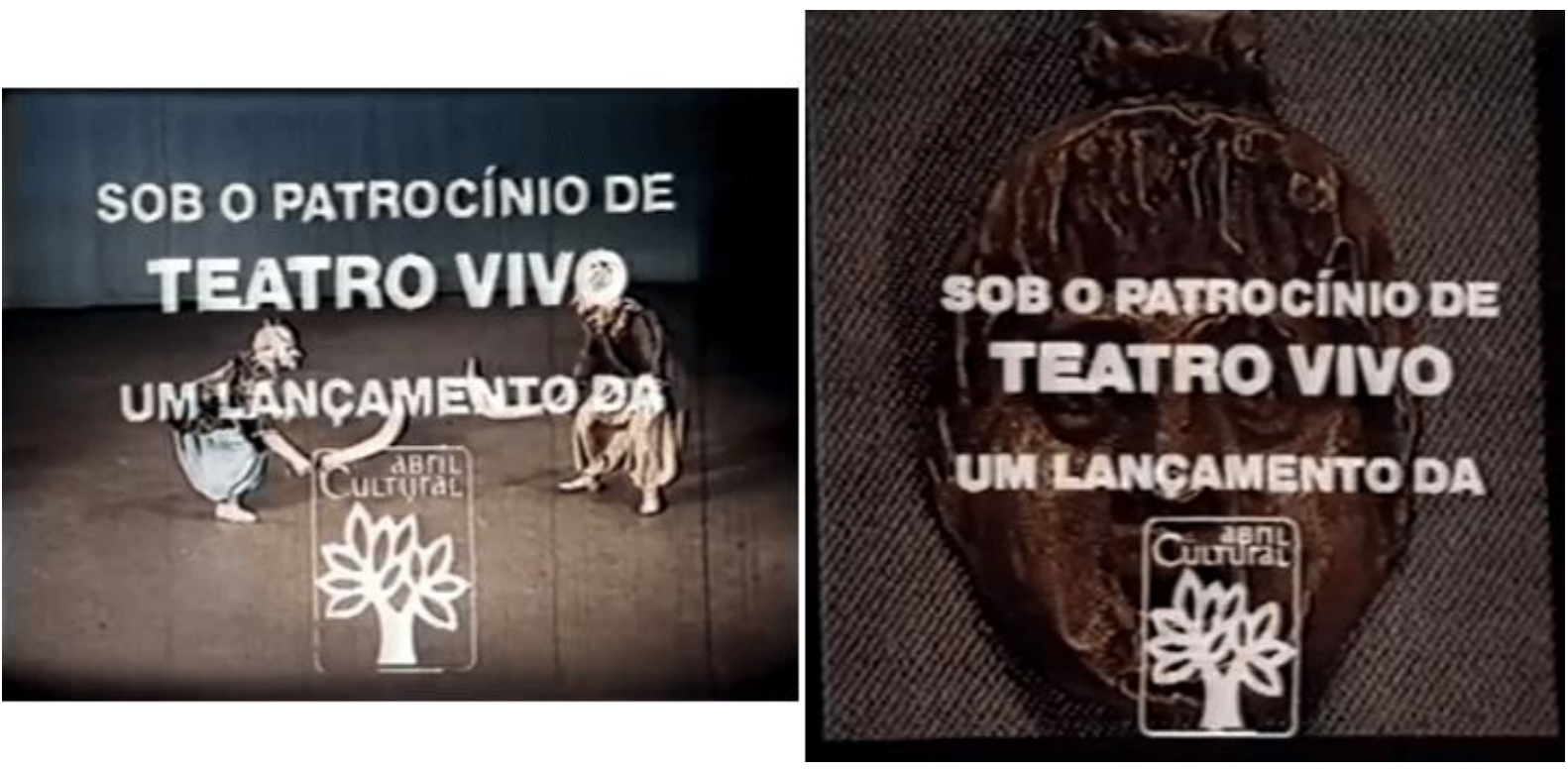

Fonte: Hesse (2015). Paulo Autran e Paulo Hesse. Disponível em: $<$ https://www.youtube.com/watch?v=PbikgepHf6M>. Acesso em: 02 ago 2017.

O espetáculo recebeu resenhas elogiosas de parte da imprensa e Antônio Abujamra (A REDESCOBERTA, 1976) teria questionado o porquê de não se fazer apenas programas como aquele na televisão. Uma análise equilibrada foi realizada por Yan Michalski (1976), com valorização dos pontos positivos (competente seleção dos textos; elenco de estrelas; desempenho extraordinário de alguns atores e atrizes; direção de Flávio Rangel superior ao de diretores de TV) e negativos (apresentação de minientrevistas com os artistas, inúteis pela sua brevidade; presença de Antunes Filho como ator; desnível na qualidade das interpretações; melodrama nas tragédias e tendência à farsa nas comédias). Houve também duras críticas, como no artigo de Helena Silveira (1976, p. 36), romancista, contista e dramaturga, que, dois dias após a apresentação, em um artigo para a Folha de São Paulo, definiu o programa como caricaturado, restrito a "[...] papelões pintados [...]", deixando o telespectador "lesado" e revelando, a quem não o conhecia, "[...] como o teatro é chato", problemas que Silveira relaciona às questões formais, ocasionados devido à falta de adaptação para uma linguagem televisiva. Salvaram-se, para a cronista, apenas os monólogos de Cleyde Yáconis, Fernanda Montenegro, Eva Wilma e a apresentação final de Elis Regina. 
Teatro Vivo foi organizada sob consultoria de Ernesto Sábato, autoridade brasileira em teatro, e o nome adotado pela coleção é homônimo ao grupo fundado por Renato Borghi e Esther Góes em 1970 e ao novaiorquino The Living Theatre, em atividade desde o final da década de 1940. A pesquisa dos textos introdutórios e do volume sobre a história do teatro ficou sob a responsabilidade de Maria Adelaide Amaral, que posteriormente seria reconhecida como uma importante autora de telenovelas e minisséries para a Rede Globo de Televisão. Sobre sua participação na Abril Cultural, a dramaturga revelaria, anos depois, a dificuldade ao ter de decidir entre a Editora e o ofício de autora teatral:

[...] eu era feliz na Abril Cultural. Apesar da ditadura lá fora, éramos uma tribo, uma família, partilhávamos das mesmas incertezas e convicções, abríamos a nossa vida uns para os outros no limite da promiscuidade. Era uma terapia cotidiana. Dar adeus a essa fraternidade seria a solidão, o exílio, o desamparo. [...] Não era o fim da história, como defendia Fukuyama, era o fim de um mundo ao qual eu pertencera, um mundo do martelar das máquinas de escrever, da fumaça dos cigarros, das redações ruidosas. [...] quando penso no que era a nossa vida nos corredores barulhentos da rua do Curtume, o meu coração ainda se aperta (AMARAL, 2016).

Teatro Vivo incluiu desde clássicos da Grécia Antiga (Édipo Rei, de Sófocles; Lisístrata e As Nuvens, de Arisófanes; Medéia e As Bacantes de Eurípedes) e algumas obras modernas (A Mandrágora, de Nicolau Maquiavel; Hamlet, de William Shakespeare; Tartufo, de Molière; Arlequim, Servidor de Dois Amos, de Carlo Goldoni), mas a maioria dos textos foi escrita por autores contemporâneos. Entre brasileiros, apenas dois tiveram espaço na série: Nelson Rodrigues, com Vestido de Noiva, e Oswald de Andrade, com O Rei da Vela. O plano da coleção, divulgado na ocasião do lançamento do volume inaugural, indicava apenas os 12 primeiros títulos $^{37}$, sem menção à quantidade de livros que comporiam a série, diferente do que ocorrera em Os Imortais da Literatura Universal e Os Pensadores, deixando em aberto a duração da coleção. Victor Civita, de acordo com seu filho, Richard ${ }^{38}$, tinha especial apreço por Teatro Vivo, que foi sua "menina dos olhos", devido ao seu entusiasmo pelo teatro e desejo de que a população brasileira assistisse a peças com maior frequência (informação verbal).

37 "Hamlet", William Shakespeare; "Édipo Rei", Sófocles; "Cyrano de Bergerac", Edmond Rostand; "O Rinoceronte", Eugene Ionesco; "Tartufo", Molière; "A Mandrágora", Maquiavel; "Fausto", Goethe; "Um bonde chamado desejo", Tennessee Williams; "Casa de Bonecas", Henrik Josen; "Entre quatro paredes", Jean Paul Sartre; "As três irmãs", Anton Tchecov; e "Pequenos burgueses", Máximo Górki.

38 Entrevista ao autor em abril de 2014. 
O volume inicial, Hamlet, foi traduzido por Péricles Eugênio da Silva Ramos, originalmente publicado pela José Olympio, em 1955, e apresentou as inúmeras notas elaboradas pelo tradutor. A reportagem publicada em Veja sobre o lançamento da coleção (A SUPERESTRÉlA, 1976) informa que alguns de seus textos eram traduções feitas para peças encenadas por diversos grupos no Brasil, mas nunca antes publicadas em livro, cujo acesso seu deu através de contribuição da "Sociedade Brasileira de Autores Teatrais (SBAT)".

No que diz respeito à edição e produção dos exemplares, ao menos um erro grave foi detectado na coleção, apontado pelo cronista Paulo Azevedo Chaves (1976), em sua coluna "Poliedro", no Diário de Pernambuco: o texto de Um Bonde Chamado Desejo, de Tennessee Williams, falha ao saltar da página 168 para a 193, terminando na 209. Para verificar a questão, foi feita a colação entre o volume de que dispomos, publicado em Teatro Vivo; a edição realizada pela editora LP\&M em 2011, traduzida por Beatriz Viégas-Farias; e um exemplar do texto original, editado em 1986 pela Signet Book, do grupo Penguin. Não foi verificado qualquer desfalque no texto, como identificado por Chaves. Entretanto, devido ao fato de os números das páginas apontados pelo cronista serem os equivalentes ao começo e fim de um caderno na edição da Abril, é possível que algumas unidades tenham, de fato, sido encadernados sem ele, resultando na identificada ausência de páginas.

Em relação ao aspecto formal e material, os exemplares, diferentemente das outras coleções estudadas, não eram acompanhados de fascículos, que foram, de certa forma, encadernados nos volumes. Após as folhas de guarda da primeira capa, foi inserido um caderno de 24 páginas, impresso no mesmo tipo de papel (couchê) dos fascículos que acompanhavam coleções anteriores. Nele é apresentada uma introdução à peça e ao seu autor, bem como o panorama histórico de sua produção e uma retrospectiva de algumas encenações já produzidas, no Brasil e no exterior. Como em Imortais da Literatura Universal e Os Pensadores, o fascículo, agora parte integrante de cada volume, tem a importante função de mediar o acesso à obra, especialmente para leitores não iniciados e sem o hábito de frequentar o teatro $\mathrm{e}$ lidar com sua estrutura textual e cênica. Porém, sob a perspectiva comercial do colecionismo, a ausência de um complemento colecionável, como os fascículos, que estimulavam a aquisição do conjunto de livros para que se pudesse encaderná-los e 
obter volumes extras, era um risco ao desestímulo ou redução da frequência de compra dos exemplares.

Os livros também se diferenciavam das outras coleções analisadas pelo formato fechado, 12 por $18 \mathrm{~cm}$, próximo ao de livros de bolso. A opção por um volume reduzido, de menor pompa que os anteriores, pode ser atribuída a dois fatores: 1) 16 dos 35 volumes (45\%) continham menos de 160 páginas, embora fossem compostos em tipos de corpo razoável (não muito reduzidos). Com textos menores, um formato maior talvez tornasse o livro mais próximo a um livreto do que a um livro colecionável ou exigisse um tipo muito grande, desproporcional ao padrão para textos literários; 2) o formato menor era mais econômico, reduzindo o preço de capa de cada livro que, em 1976, já era três vezes superior ao de Os Imortais... e duas vezes superior ao de Os Pensadores, ainda que estes fossem de maior formato. A necessidade de se manter em um valor razoável o preço dos livros ocorreu por conta da redução do poder aquisitivo do público consumidor após a crise do "milagre econômico".

A capa dos exemplares (Fig. Figura 34) tinha o padrão vermelho, e foi feita com o mesmo material das coleções já analisadas: base em acartonado com revestimento de papel recoberto com lâminas vinílicas (PVC), de textura emborrachada, que remetem à aparência do couro, estendendo-se por cerca de $0,3 \mathrm{~cm}$ a $0,4 \mathrm{~cm}$ para as guardas, formando a seixa. O cabeceado inserido não seguia o modelo das outras coleções, manifestando uma alternância entre a cor amarela e uma outra de tom semelhante ao verde claro, que não replicava a cor da capa. Teatro Vivo também se distinguia pela ausência de ornamentos e arabescos, apresentando em hot stamping dourado o nome da coleção, ao topo; o título da obra, em destaque, ocupando o espaço da parte superior até próximo ao meio; o nome do autor, em fonte menor que o título, na parte médio-inferior; e o nome da editora em sua base. A lombada (Fig. Figura 34), também sem ornamentos e arabescos, vinha inscrita apenas com o título da obra, nome do autor e símbolo da editora. Mais uma característica particular da coleção é a ausência de número que identifique os exemplares segundo sua ordem de publicação. Desta forma, a melhor maneira de conseguir uma sequência para o catálogo, além da consulta a fontes da época, é a identificação do mês e ano de publicação no verso da folha de rosto, embora este não seja um método seguro, devido à inconsistência entre o período de 
publicação e sua indicação nos exemplares, conforme ocorreu em Os Imortais da Literatura Universal e Os Pensadores.

Figura 34 - Lombada e capa padrão de um exemplar de Teatro Vivo

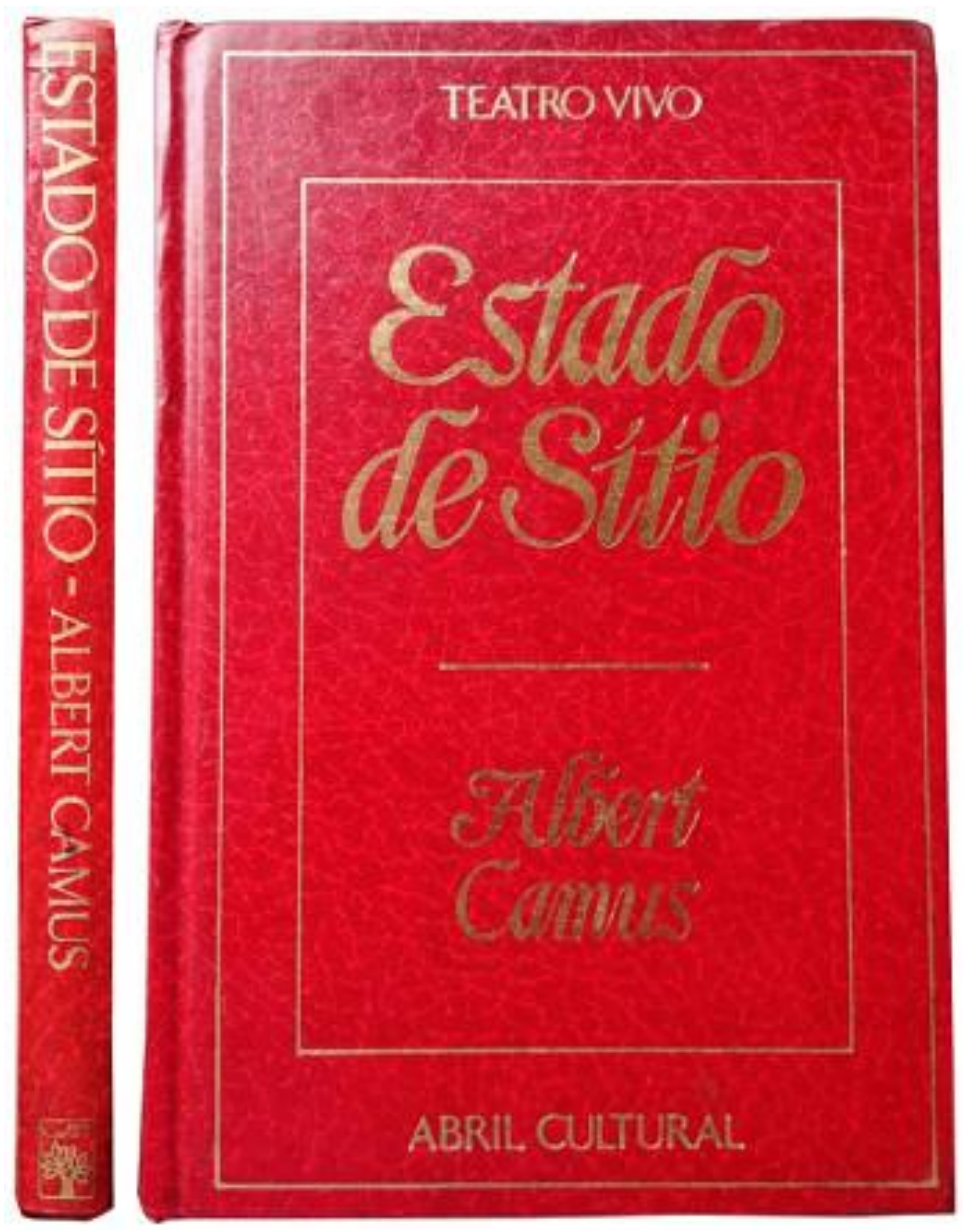

Fonte: acervo particular do autor.

No que diz respeito ao texto, os volumes foram impressos integralmente em fonte serifada (com exceção da identificação de créditos nas estampas do fascículo introdutório), seguindo a organização típica de obras teatrais, com caracterização dos personagens, apresentação prévia de cada cena e diálogos identificados. Ao fim do volume, há sempre o índice, que remete ao caderno introdutório e às cenas da peça. O colofão informa apenas o local de composição e impressão: "Composto e impresso nas oficinas da / Abril S.A. Cultural e Industrial, / caixa postal 2372 - São Paulo". Na seção inferior da página de créditos, todos os livros da Coleção ostentam 
o aviso de que a peça não poderá ser encenada sem a autorização da Sociedade Brasileira de Autores Teatrais (SBAT):

Esta peça, na presente tradução, só poderá ser encenada ou utilizada, no todo ou em parte, seja por que processo for, mediante autorização expressa da SBAT - SOCIEDADE BRASILEIRA DE AUTORES TEATRAIS - Av. Almirante Barroso, 97, $3^{\circ}$. Andar, Rio de Janeiro. Todo abuso será considerado violação da propriedade intelectual, nos termos dos Códigos Civil e Penal.

O primeiro exemplar a ser analisado é Estado de Sítio, de Albert Camus, publicado em agosto de 1977, conforme indicação no verso da folha de rosto. Contém 180 páginas ao todo, mas que possuem numerações separadas. A seção introdutória possui 24 páginas, numeradas em algarismos romanos de IV a XXIII e a peça em si possui 156 páginas, numeradas de 13 a 151, com paginação sempre na extremidade inferior direita. O conjunto do miolo e das capas resulta em uma espessura total de $1,4 \mathrm{~cm}$. O fascículo introdutório conta com 12 estampas em preto e branco, representando Camus (na cerimônia em que recebe o Prêmio Nobel de Literatura, ao lado da rainha Vitória, da Suécia, em 1957; e, também, orientando autores em montagens de suas peças); Sartre (por seu apoio à libertação da Argélia, país natal de Camus); e uma série de fotografias de representações de "Estado de Sítio" em diferentes montagens. A folha de rosto encontra-se no fascículo, na primeira página do livro após a folha de guarda, embora haja uma espécie de segunda folha de rosto abrindo o texto da peça (sem indicação do editor).

A separação entre o caderno introdutório e a peça é visível pela diferença de papéis utilizados (couchê, em um; papel convencional para livro, na outra). Esta condição, presente em todos os volumes da coleção, induz à sensação de que o fascículo, que em outras coleções veio à parte, para ser colecionado, foi introduzido na encadernação, ainda que o projeto inicial talvez não fosse este. No entanto, pode ser que os editores tenham optado pelo papel couchê no caderno introdutório devido a sua melhor representação das estampas inseridas e para demarcar a diferença entre o complemento e o texto da peça.

A folha de rosto é equilibrada, mesmo que não traga a autoria, um erro significativo. Marat-Sade, de Peter Weiss, foi publicado um mês antes que Estado de Sítio e apresenta o nome do autor em sua folha de rosto (Fig. Figura 35). A tradução foi feita por Maria Jacintha, publicada anteriormente pela Livros do Brasil, de Lisboa, em 1949, ano seguinte ao do original francês, editado pela Gallimard. No Brasil, a 
Abril foi a primeira casa a editar a obra. As margens do caderno introdutório seguem a dos outros cadernos, com variação muito pequena: entre $1,7 \mathrm{~cm}$ e $1,8 \mathrm{~cm}$ nas margens externas; $2 \mathrm{~cm}$ e 2,1 cm nas superiores; entre $1,4 \mathrm{~cm}$ e $1,7 \mathrm{~cm}$ nas inferiores (aqui com diferença de 0,1 cm entre o padrão do caderno introdutório e os outros); e $0,9 \mathrm{~cm}$ e $1,2 \mathrm{~cm}$ nas internas. A mancha tipográfica do texto possui $8,7 \mathrm{~cm}$ de largura por $13,8 \mathrm{~cm}$ de altura. A fonte é em tamanho agradável e o entrelinhamento correto, embora em peças de teatro seja menos perceptível um entrelinhamento curto que nos textos corridos de outros gêneros literários. 
Figura 35 - Folhas de rosto de Estado de Sítio e Marat-Sade

\section{Teatro Vivo}

\section{ESTADO DE SÍTIO}

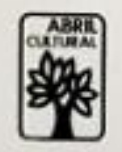

Editor

VICTOR CIVITA

\section{TEATROVTVO}

\section{PETER WeES \\ MARAT-SADE}

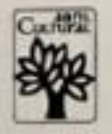

Editor

VICTOR CIVITA

Fonte: acervo particular do autor.

Outro aspecto a se pontuar sobre o exemplar em questão é o fato de estar, ainda, com parte de suas páginas por abrir, indicativo de que o proprietário anterior (ou os proprietários, já que o volume foi adquirido em uma loja de livros usados) não leu efetivamente todo o texto da peça. Esta condição é particular, pois, por falha do refile, algumas páginas permaneceram fechadas, o que não é o padrão da coleção e não permite, portanto, afirmar que em outros volumes os cadernos foram abertos pelos antigos donos.

O segundo livro em análise é Cyrano de Bergerac, de Edmond Rostand, editado em maio de 1976 como o terceiro volume da coleção, após Hamlet e Édipo Rei. Possui 367 páginas, sendo 24 do caderno inicial, numeradas de IV a XX, e 343 referentes ao texto da peça, numeradas de 11 a 337, com espessura total de $2,6 \mathrm{~cm}$, inclusas as capas. O fascículo introdutório possui diferenças em relação a Estado de Sítio: 1) não possui impressão na primeira e na última folha do caderno, o que resulta em páginas em branco, não numeradas; 2) embora tenha menos páginas 
impressas, apresenta 13 estampas (uma a mais que a peça de Camus), sendo cinco delas coloridas e apenas uma retratando Rostand, em preto e branco. A folha de rosto é harmoniosa, composta pelo nome do autor ao topo; o título está próximo ao centro, mas ligeiramente voltado ao segmento superior da página; e o símbolo da editora e o nome de Victor Civita, identificado como editor, ambos no segmento inferior. Nota-se que, com este, já foram identificados três modelos diferentes de folha de rosto nos exemplares, compostos por: 1) "Estado de Sítio", com nome da coleção, título da obra e símbolo da editora e nome do editor; 2) "Marat-Sade", com nome da coleção, autor, título do livro e símbolo da editora e nome do editor; 3) Cyrano de Bergerac, com autor, título da peça e símbolo da editora e nome do editor.

A tradução foi realizada por Carlos Porto Carreiro, embora a Abril não indique na edição anterior. A versão de Carreiro, poeta e membro da Academia Pernambucana de Letras, foi publicada pela primeira vez no começo do século $X X$, pela editora carioca J. Ribeiro dos Santos e reeditada em 1912 e 1922. Em 1944, a Editora Irmãos Pongetti a relança em sua coleção As 100 Obras da Literatura Universal, após a qual seria reeditada em pelo menos outras três oportunidades (1947, 1955, 1966). A publicação em Teatro Vivo foi feita, portanto, dez anos após a provável última reedição da Pongetti, e a anotação de direito autoral da tradução é curiosa: "Tradução publicada com a licença de Carlos Porto Carreiro". Porto Carreiro, porém, faleceu em 1932, não sendo possível que licenciasse sua tradução de Cyrano de Bergerac em Teatro Vivo, publicada mais de quatro décadas depois de sua morte. Não há, nos créditos, indicação de herdeiros ou de instituições responsáveis pelo direito autoral, já que a obra não se encontrava em domínio público, por não terem decorrido mais de sessenta anos do falecimento do autor ou de seus herdeiros, conforme a lei de direitos autorais em vigor no momento (Lei no 5.988 de 1973).

Sobre a composição do texto, pode-se identificar mancha tipográfica de $8,8 \mathrm{~cm}$ de largura por $13,8 \mathrm{~cm}$ de altura. As margens externas possuem entre $1,6 \mathrm{~cm}$ e $1,7 \mathrm{~cm}(1,4 \mathrm{~cm}$ a $1,8 \mathrm{~cm}$ no caderno introdutório); as internas, $0,6 \mathrm{~cm}$ a $0,8 \mathrm{~cm}$ ( $0,9 \mathrm{~cm}$ a $1,3 \mathrm{~cm}$ no caderno introdutório); as superiores, $1,9 \mathrm{~cm}(1,4 \mathrm{~cm}$ a $1,7 \mathrm{~cm}$ no caderno introdutório); as inferiores, $1,5 \mathrm{~cm}$ a $1,6 \mathrm{~cm}(1,6 \mathrm{~cm}$ a $2 \mathrm{~cm}$ no caderno introdutório). Há sete páginas de notas do editor logo após o final do texto da peça 
(60 notas ao todo) e uma folha em branco antes da folha de guarda da contracapa (que não existe após a guarda da capa). A fonte é de bom tamanho, embora menor que nos outros exemplares analisados, provavelmente devido à extensão do texto, e o entrelinhamento é suficiente.

O terceiro volume da série a ser avaliado é Um Bonde Chamado Desejo, de Tennessee Williams. O livro, conforme dados da página de créditos, foi editado em setembro de 1976 e conta com tradução de Brutus Pedreira, ator, tradutor e músico poliglota, personagem relevante para o teatro brasileiro, falecido em 1964, cujos direitos sobre as obras, pertencentes aos herdeiros, desta vez mencionados pela editora, estão sob guarda da SBAT. A tradução de Pedreira, que não tem edição anterior em livro, foi feita para a montagem da peça, realizada em outubro de 1963 (UM BONDE..., 2017), pela “Companhia Maria Fernanda” de teatro.

O volume possui 232 páginas, sendo 20 referentes ao caderno introdutório e 212 ao texto da peça, resultando em uma espessura de $1,8 \mathrm{~cm}$. O primeiro caderno, com a apresentação da obra, autor e montagens, foi encadernado de maneira diferente em relação aos outros exemplares analisados. Nos outros volumes, a guarda é produzida por uma folha de maior gramatura que o miolo do livro, colada metade à capa e mantendo a outra metade solta, como uma folha de guarda. Já neste exemplar da peça de Tennessee Williams, a guarda da capa foi montada pela colagem da primeira folha do fascículo, produzido em papel couchê, diferente das demais guardas e folhas de guarda presentes nos outros volumes da série. A guarda e a folha de guarda da contracapa, porém, seguem o padrão do restante da coleção. O fascículo possui 12 estampas, representando o autor e encenações da peça, sendo quatro delas coloridas.

As margens se apresentam com as seguintes variações de espaços: superiores, $1,4 \mathrm{~cm}$ a $2,1 \mathrm{~cm}(1,6 \mathrm{~cm}$ a $2,5 \mathrm{~cm}$ no fascículo); inferiores, $1,4 \mathrm{~cm} \mathrm{a}$ $1,8 \mathrm{~cm}$ (2 cm a 2,1 cm no fascículo); externas, $1,5 \mathrm{~cm}$ a $1,7 \mathrm{~cm}(1,6 \mathrm{~cm}$ a $1,8 \mathrm{~cm}$ no fascículo); internas, $0,6 \mathrm{~cm}$ a $0,7 \mathrm{~cm}(0,9 \mathrm{~cm}$ a $1,1 \mathrm{~cm}$ no fascículo). A mancha tipográfica mede $8,8 \mathrm{~cm}$ de largura (idem no fascículo) por $14 \mathrm{~cm}(13,2 \mathrm{~cm}$ no fascículo). A fonte mantém o bom padrão dos outros volumes da série, com tamanho adequado e entrelinhamento correto.

Será avaliado, por fim, o livro brinde que foi entregue junto ao primeiro volume da coleção, Hamlet. Este exemplar, denominado "Introdução e História", possui, em 
relação ao miolo, características diferentes dos outros: conta com 64 páginas, impressas todas em papel couchê, divididas em quatro cadernos de 16 páginas cada. As guardas e folhas de guardas são as únicas em papel diferente, de maior gramatura, conforme padrão da coleção. O cabeceado não está presente como nos outros volumes, provavelmente uma opção feita devido ao tamanho do exemplar. Somadas as capas, o livro possui apenas $0,9 \mathrm{~cm}$ de espessura.

A folha de rosto não indica autoria, apenas o título Teatro Vivo, que também é o da coleção, posicionado na parte superior, próximo ao meio da página, além do símbolo da editora e o nome do editor "Victor Civita". São inclusas 39 estampas, sendo 18 coloridas e 21 em preto e branco, retratando autores; encenações em diversas montagens de peças; ilustrações e obras de reconhecido valor na história da arte, todas relacionadas ao universo do teatro, com o propósito de auxiliar na compreensão do texto. Há ainda uma apresentação da coleção por Victor Civita.

Em relação à composição, observa-se uma mancha tipográfica de $8,8 \mathrm{~cm}$ de largura por 13,7 a 14,5 de altura, o que corresponde à maior variação vertical encontrada em todas as manchas analisadas. Duas estampas ocupam toda a área da página, sem margens, e outras duas ocupam o espaço de duas páginas inteiras, também sem margens. Os espaços de marginação estão assim presentes no exemplar: superiores $1,5 \mathrm{~cm}$ a $2,1 \mathrm{~cm}$; inferiores $1,3 \mathrm{~cm}$ a $1,6 \mathrm{~cm}$; externas $1,4 \mathrm{a}$ $1,9 \mathrm{~cm}$; internas $0,7 \mathrm{~cm}$ a $1,2 \mathrm{~cm}$.

É prática, ainda hoje, a identificação de cada caderno de um livro com nomes, siglas ou qualquer elemento que facilite sua montagem no momento da encadernação. Um elemento interessante encontrado no exemplar avaliado é a especificação do segundo caderno: "TEATRO 1 (ENRIQUECIMENTO) - 2 ${ }^{\circ}$. CAD". "TEATRO 1" refere-se ao fato de o volume ser o primeiro da coleção (junto à "Hamlet"); "ENRIQUECIMENTO" demonstra que o livro tinha por objetivo "enriquecer" a coleção, dotando-a de um elemento a mais em relação à simples publicação dos números; " $2^{\circ}$. CAD" é posição a ser ocupada no momento da encadernação. O exemplar, diferente dos demais, apresenta os créditos da equipe que elaborou a coleção, enquanto os outros referem-se apenas aos responsáveis pela produção do próprio volume em que estão inseridos. 
Encerradas as análises realizadas nos exemplares, é possível identificar determinadas características formais/materiais e textuais que revelam particularidades e condições do processo de edição e produção dos livros colecionáveis. No aspecto econômico, os formatos, apesar de distintos nas três coleções observadas, estão dentro da regra de melhor aproveitamento do papel de imprensa, o que reduz perdas e otimiza o gasto com o suporte, que corresponde a uma parcela importante do custo de produção gráfica de um livro. Em relação ao texto, uma opção adotada pela Abril foi a compra de direitos autorais de traduções anteriormente publicadas por outras editoras, muitas delas com edições esgotadas $\mathrm{e}$ fora de catálogo, que poderiam ser negociadas por valores melhores. A característica de reimpressão de obras já comercializadas pelo mercado convencional de livros é um dos métodos mais utilizados em edições destinadas ao circuito alternativo ao das livrarias para se reduzir custos e manter o valor acessível ao grande público, e a Abril fez uso deste recurso sempre que possível, embora também traduzisse textos sem outras versões em português, quando necessário.

Apesar de possuir estrutura privilegiada e uma equipe competente trabalhando na preparação dos textos, alguns deles apresentam sérios problemas de preparação e revisão de texto e encadernação, como se identificou nas análises. Em determinadas obras, a necessidade de se ajustar um texto longo aos limites de um volume produzia livros com entrelinhas inadequadas para o pequeno tamanho dos tipos utilizados. De fato, algumas opções da Abril em relação ao texto fazem crer que a Editora não tinha expectativa de que os colecionadores lessem todas as obras ou que, pela pouca experiência com outras edições, não se importassem com a dificuldade que uma composição mal-feita pudesse provocar no processo de leitura, mesmo que um problema ergonômico pudesse afastar do hábito um leitor iniciante.

Sob o ponto de vista formal/material, os livros da Abril eram, de maneira geral, bem editados, apesar de haver problemas em determinados exemplares (ou lotes deles) que prejudicam uma experiência uniforme de leitura entre os diversos colecionadores. Como a forma determina, condiciona e modifica a apropriação, os leitores da coleção, à parte suas características individuais, experimentaram de maneira distinta os textos literários e filosóficos publicados pela Editora nas coleções que foram objeto de análise. 
As manchas tipográficas possuem muito pouca variação (quando ocorre), motivo pelo qual se conclui que as diferenças observadas no espaçamento das margens advêm de erros gráficos, como problemas no refile, impressão e encadernação, e não de edição dos textos. Embora os defeitos de marginação não sejam equívocos da composição, os problemas com a escolha inadequada de corpo dos tipos, entrelinhamento e páginas de rosto são o que indica que a Editora não esperava que os volumes fossem adquiridos por leitores mais experientes, dotados de capacidade para avaliar estas questões, mesmo que, com o acesso de críticos literários e jornalistas, os defeitos técnicos pudessem ter sido expostos.

Boa parte dos problemas que foram identificados estavam atrelados à necessidade de se reduzir custos: a compra de direitos de edições anteriores, que, em alguns casos, não eram as melhores ou vinham com problemas no texto; o reduzido tempo de edição e produção dos livros, que sobrecarregava a equipe editorial, não suficientemente dimensionada para as contingências dos projetos; a alta tiragem, que diluía as despesas gráficas e editoriais, mas que demandava alta quantidade de insumos (resultando em problemas na demanda de papel pela indústria nacional) e dificultava a correção de falhas após a rodagem de muitos exemplares, o que resultaria em atraso no processo e aumento de custos.

Outro aspecto fundamental para o sucesso das coleções eram suas características materiais. A encadernação, em capa dura ornamentada, remetia ao público a sensação de uma obra de valor maior que o efetivamente cobrado pelos exemplares, da mesma forma que a eles confiava um aspecto muito decorativo, ideal para exposição nas salas de uso comum das casas, onde o conjunto de livros poderia significar mais por sua forma que por seu conteúdo. Márcio Saldanha Marinho (CALDAS, 1974), então diretor do Departamento de Promoção e Pesquisa da Distribuidora Fernando Chinaglia, uma das maiores do país, em reportagem sobre a venda de livros em bancas de jornais feita pelo Diário de Notícias, em 1974, assegurou que grande parte do público consumidor das coleções não as lia, ao menos por inteiro, motivo pelo qual os editores buscavam maior esmero na produção das capas, que deveriam ornamentar as estantes.

Os livros colecionáveis da Abril emulavam, de fato, volumes mais caros, de luxo e desejados por colecionadores experientes e dotados de condição financeira 
diversa do público a quem se destinavam as obras da Editora. Porém, era improvável que colecionadores de livros raros e especiais demonstrassem interesse por aqueles que, em sua visão, seriam comuns, de alta tiragem e vendidos em bancas de jornal. Somado a isto, os visíveis erros na composição e encadernação, também presentes em outras edições convencionais, afastariam o público iniciado, com conhecimento em técnicas tipográficas e editoriais, que procuravam no livro não apenas uma fonte de informação, mas também de prazer estético. A circulação fora das livrarias era também vista com desconfiança pelo público habitualmente consumidor de livros, embora não especialista em artes gráficas, que supunha encontrar nestes volumes textos incompletos, condensados, de baixa qualidade, literatura leve e para consumo rápido.

As coleções da Abril buscavam atender a um público específico e a Editora tinha consciência do que esse público exigia e com o que não se importava, bem como sabia que era, como demonstrou-se, constituído por setores de classes sociais intermediárias que ainda estavam em trânsito e procurando estabilizar-se, econômica e socialmente; e muitos deles pela primeira vez experimentavam a posse e usufruto de bens considerados de elite em anos anteriores. O livro era um deles, e houve uma flutuação entre o desejo pela obra como instrumento educativo e instrutivo e como símbolo de distinção e ostentação, como ficou claro na passagem sobre dona Martha e sua busca pelo fascículo que iria auxiliar a filha em um trabalho escolar e depois terminaria nas estantes de sua sala. Acima disso, as coleções de livros da Abril eram um mecanismo para formação de identidade, em um momento de profundas transformações políticas, econômicas, sociais e culturais no Brasil. A Editora se utilizará desta espécie de vazio gerado pelas condições do período para convencer seu público de que parte da identidade poderia ser estabelecida a partir do consumo de livros que garantiam erudição, preparo e opulência, características observadas e ambicionadas em classes altas. O mecanismo de convencimento e persuasão foram as extensas campanhas publicitárias que antecipavam e procediam ao lançamento das coleções. 


\section{O ADUBO QUE FEZ A ÁRVORE CRESCER: PROPAGANDA E PÚBLICO}

A década de 1960 foi o período das revoluções, da contracultura e também dos golpes; do 1968 da esperança, na França, ao 1968 da desilusão, no Brasil. Mas o desapontamento com a restrição às liberdades não foi generalizado no país. Com o início do "milagre econômico", a facilidade de acesso ao crédito e a bens de consumo melhorou o padrão de vida de uma parcela da população, para a qual as coisas pareciam muito bem. Havia emprego, conquanto se precisasse de turnos extras para complementar renda, carro e casa próprios, com direito à geladeira e televisão. O Brasil era o "país do futuro", ainda que Stefan Zweig já estivesse morto há quase 30 anos. Faltava, no entanto, algo que apenas os bem posicionados socialmente possuíam: cultura. Essa palavra, por vezes hermética, designava a substância que parecia estar ausente e que os crediários não financiavam. Mas, em algum momento, alguém nas TVs, nos rádios, nas bancas, nas revistas, nos jornais, nos outdoors, nos panfletos, em tapumes e muros passou a dizer que não: isso, a cultura, também é para você. Você pode ler, pode ler com seus filhos, com sua esposa. Pode ouvir e fazer. Pode ser melhor. Pode parecer melhor. Pode, enfim, ter o privilégio. Devagar, no seu tempo e para o seu bolso. Por uma módica quantia, em todas as bancas de jornais.

A máquina de sugestão que é a propaganda trabalhou a todo vapor na década de 1970, que foi também o período em que a publicidade feita no Brasil alcançou nível internacional de desenvolvimento, com excelente qualidade técnica das peças e campanhas, de acordo com o que de melhor se fazia nos países de maior tradição. Tal patamar foi alcançado por fatores contextuais, entre os quais: a Lei $n^{\circ} 4680$, promulgada em 18 de junho de $1965^{39}$, que regulou o exercício das atividades de publicitários e de agenciadores de propaganda, estabeleceu regras para a remuneração e conduta dos profissionais, além de proporcionar melhores condições aos trabalhadores do setor e maior garantia às agências, que puderam se estruturar de forma adequada e investir no aperfeiçoamento de seu trabalho criativo; o período de euforia econômica entre o final da década de 1960 e meados da

39 Disponível em: <http://www.planalto.gov.br/ccivil 03/Leis/L4680.htm>. Acesso em: 22 ago. 2017. 
seguinte, em que se estabeleceu condições favoráveis ao surgimento, de acordo com Roberto Dualib ([1980?]), de novos profissionais no mercado, competentes e preparados para atender à nova demanda de clientes. O resultado desse processo de modernização e profissionalização transformou o mercado de publicidade nacional em um dos dez maiores do mundo (SALLES, [1980?]).

O crescimento da atividade industrial fez surgir a necessidade de se explorar e/ou formar novos públicos consumidores. A oferta de produtos semelhantes ampliou a concorrência e a disputa pelo consumidor passou a ser travada também nos veículos de massa (televisão, rádio, revistas, jornais, outdoors, cinema, entre outros) através de peças publicitárias. A competição pelo público modificou a forma como as agências trabalhavam. A propaganda baseada na intuição, comum em anos anteriores, foi substituída, segundo Márcio Moreira ([1980?], p. 49) pela “[...] adoção de técnicas que permitem ao publicitário conhecer melhor o consumidor. É a chegada do marketing como um todo". A necessidade de se produzir retorno financeiro condizente com o investimento do cliente tornou inevitável que as pesquisas de público fizessem parte do cotidiano das agências, para que pudessem segmentar suas peças de acordo com cada produto e seu consumidor em potencial.

Os avanços obtidos e a qualidade da propaganda feita no Brasil foram motes para o amplo investimento em publicidade por parte das empresas nacionais e internacionais que atuavam no país, conforme é possível observar no Quadro 1. Nem mesmo a crise experimentada após o fim do milagre foi suficiente para reduzir as verbas gastas com divulgação de produtos e serviços. Em 1974, quando se começou a sentir os efeitos da instabilidade econômica, houve queda no nível de crescimento, que se acentuou em 1975, mas que se seguiu de dois excelentes anos para o setor (1976 e 1977); consequência, provavelmente, das investidas de Geisel e seus Planos Nacionais de Desenvolvimento. Apenas no final da década, em 1979, já com o cenário que se agravaria nos anos 1980 em vista, ocorreu a primeira retração. 
Quadro 1 - Investimento em propaganda

\begin{tabular}{|c|c|c|}
\hline Ano & Valor (milhões Cr\$) & Crescimento Real (\%) \\
\hline 1972 & 3460,0 & 17,8 \\
\hline 1973 & 4490,9 & 12,3 \\
\hline 1974 & 6300,1 & 9,0 \\
\hline 1975 & 8200,5 & 1,9 \\
\hline 1976 & 13650,4 & 20,2 \\
\hline 1977 & 22675,4 & 27,3 \\
\hline 1978 & 33813,0 & 5,1 \\
\hline 1979 & 59265,3 & $-1,9$ \\
\hline
\end{tabular}

Fonte: Meio \& Mensagem ([1980?], p. 75).

As classes médias foram um dos públicos preferenciais das empresas para ofertarem seus produtos. Apesar de não ser o estrato com maior poder econômico, era onde, nos centros urbanos, boa parte da população com capacidade e potencial de compra para bens culturais se localizava. A partir disso, uma das funções da propaganda foi convencer os componentes dessa camada social a investirem em produtos culturais ao invés de pouparem o excedente de capital, movimentando, assim, a indústria cultural ainda incipiente no país durante a década de 1970, conforme Miceli (2005), devido ao limitado alcance da escolarização no Brasil.

O discurso publicitário foi responsável, portanto, por introduzir entre os setores intermediários da sociedade uma demanda pelos produtos culturais, como os comercializados pela Abril Cultural, que eram distintos dos periódicos publicados pela Editora Abril. Para que esse propósito fosse satisfeito, os profissionais de marketing das agências contratadas pela empresa ocuparam-se da criação de identidade com os produtos classificados como de "alta cultura", integrantes do conjunto de símbolos da sociedade de consumo pós-industrial. Ao induzirem o indivíduo a depositar, no ato de consumir, a satisfação do desejo pela participação em um determinado padrão de vida, associado a estratos sociais superiores, incentivaram, ao mesmo tempo, a competição dentro da própria camada social pela posse de objetos distintivos e ostentatórios que começavam a circular entre classes médias. 
Esse processo origina um circuito de eventos causais em que o sujeito, persuadido pela propaganda, adquire determinado item por sua associação a uma classe mais alta, impelindo os demais membros da mesma classe, por não possuírem o produto, a sentirem-se "inferiores", e também o adquirirem para corrigir a defasagem. Tal dinâmica identitária, além de multiplicar o poder de circulação dos bens simbólicos, produz uma dualidade subjetiva: precisa-se do produto para ser outro, mas, da mesma forma, para ser o que se é. $O$ incômodo e a frustração que este modelo provoca levam à permanente insatisfação pessoal vinculada às ações $e$ bens dos outros, que passam a ser o inferno ${ }^{40}$.

Tem-se, então, a dupla função de integração e diferenciação, que Baudrillard (2009, p. 188-189) define como paradoxo, pois "[...] somos induzidos a comprar em nome de todo mundo, por solidariedade reflexa, um objeto sobre o qual nossa primeira providência será usá-lo para diferenciar-nos dos outros". Nesse processo, identificam-se propagandas da Abril que comunicam ao público de que muitos já estão colecionando, mas que "você" colecionar é um "privilégio". Como os privilégios são prerrogativas de especificidade, produz-se o paradoxo. Nota-se que o discurso se condiciona mais pelo acesso a um produto considerado de elite, erudito, legitimado, do que pela limitação de pessoas que o possuem.

\subsection{A cultura de massa}

O processo de desenvolvimento industrial do Brasil, especialmente na década de 1970, multiplicou a oferta e o acesso a eletrodomésticos, automóveis, eletroeletrônicos, vestuário, bebidas e toda sorte de bens de consumo, que a publicidade passaria a persuadir à compra, como vimos. A cultura, especificamente 0 produto cultural, foi também um importante mercado, dominado por grandes empresas de comunicação. Entre seus bens, o livro ganhou destaque fundamentalmente pela ação da Abril. A propaganda de livros, até então restrita a

40 O filósofo existencialista Jean-Paul Sartre, em sua peça "Entre Quatro Paredes" (Huis Clos), publicada pela primeira vez no Brasil em 1977, na coleção "Teatro Vivo", faz Garcin compreender, após uma clausura forçada com três outros personagens, que o inferno não é composto pelo cheiro de enxofre, fogueira ou grelha, como se imagina; mas pela presença do outro, com todos os olhares que lhe consomem. 
anúncios em classificados dos jornais, quase perdidos entre tantos outros, ou peças nas sessões literárias, que nem todos os jornais possuíam, passou a ser feita como as de outras mercadorias, em diversos veículos: de rádio à televisão, através de intervalos comerciais e patrocínio a programas; outdoors; anúncios de mais de uma página em periódicos de grande circulação; marketing direto e todo tipo de mídia que pudesse comunicar aos possíveis consumidores sobre a existência das coleções.

O investimento era na ordem de milhões de cruzeiros, que apenas uma companhia com a estrutura econômica da Editora Abril poderia realizar. O custo, diluído entre as dezenas de volumes da coleção, tornava viável o que para um único título seria impensável; e uma ampla gama de potenciais leitores (ou potenciais consumidores) poderia, a partir daí, ter contato com aquela "mercadoria chamada livro", como propôs Lobato (1955) em 1918, passando a fazer parte das mensagens cotidianas que Ihes eram comunicadas à exaustão. Assim, estava constituída uma "massa" de indivíduos que se tornaria o público-alvo de fascículos e livros colecionáveis.

Os livros da Abril foram algumas das raras publicações bem-sucedidas em disponibilizarem textos de "alta cultura" no circuito da chamada "cultura de massas". Considerada aqui sob a perspectiva apontada por Umberto Eco (2006), a "alta cultura" origina-se da divisão proposta por Dwight MacDonald de produtos canonizados pela crítica e que, até então, estavam reservados a um público limitado às elites sociais do país, em oposição à cultura de massa (itens populares, de ampla circulação) e à média cultura (que pretende se passar por alta cultura, forjando-a). Eco (2006, p. 54-56) adverte, porém, que a "alta cultura" não pode ser unicamente vinculada às elites, uma vez que nem todos os seus membros a apreciam, estando sujeitos ao consumo de produtos de outros níveis culturais, da mesma forma que indivíduos de classes inferiores, através de coleções "populares", podem usufruir dos "valores superiores" da cultura das elites. Os "níveis", por sua vez, não representam necessariamente o valor dos bens simbólicos, pois há um intrincado conjunto de julgamentos que formam um "panorama mais complexo do que se crê" e cada obra pode exercer diferentes funções em diversos estratos. 
Para o panorama brasileiro do início da década de 1970, Sérgio Miceli (2005) defende que estavam presentes, sob a ótica do capitalismo "central", determinadas características que restringiam a cultura de massa: relação de dependência na determinação do sentido dos níveis culturais; limitada autonomia simbólica dos bens culturais; sociedade industrial de consumo reduzida aos centros urbanos de maior concentração demográfica; limitação, nestes mesmos centros urbanos, de parte da população à mera condição de subsistência; inibição da formação de "massa" devido ao remanejamento radical das classes; ausência de um caráter nacionalista unificador na formação da cultura de massas como ocorreu em países capitalistas centrais.

Ainda sob o ponto de vista de Miceli, pode-se dizer que a Abril e outros meios de comunicação produzem uma espécie de cultura de massa "à brasileira". De certa maneira, a dependência nacional ante a cultura hegemônica internacional se dá pela influência de uma burguesia estrangeira mais bem desenvolvida que a nacional. $O$ resultado dessa dependência pode ser constatado na composição do catálogo das coleções de livros da Editora, sempre favoráveis à cultura estrangeira, o que deu origem à noção de cultura clássica que enviesou a escolha nos editores, conforme fica demonstrado por Fernando Nuno $^{41}$ (Anexo IV), preparador de textos na Abril Cultural e, posteriormente, editor na Círculo do Livro, em entrevista ao autor. Questionado sobre o motivo de a seleção sempre privilegiar autores estrangeiros, declarou:

\footnotetext{
"talvez não fosse nem consciente para nós, editores, mas se Machado de Assis e Victor Hugo, por exemplo, eram clássicos, acabavam integrados em duas categorias distintas, não a mesma: o clássico brasileiro e o clássico estrangeiro. Então, quando se falava em grandes clássicos da literatura, eram lembrados só os estrangeiros" (informação verbal).
}

Nota-se, pelo depoimento de Nuno, que havia um conceito enraizado nos profissionais da Editora de que a literatura brasileira, ainda que "clássica", era uma categoria à parte, que não foi associada à "universalidade" dos clássicos que compunham a coleção "Imortais da Literatura Universal". Essa ideia esteve presente nos critérios dos editores, que, diferentemente dos proprietários da Abril, eram 
brasileiros, e como "[...] clientelas intelectuais[...]" coube a eles ${ }^{42}$ administrar "não só as condições de dependência que regulam a reprodução material, mas também a produção teórica e ideológica que dissimula o novo esquema de dominação" (MICELI, 2005, p. 136).

A cultura de massa surge quando "[...] as massas ingressam como protagonistas na vida associada, corresponsáveis pela coisa pública" e, a partir disso, seu "[...] modo de pensar, de imaginar não nasce de baixo: através das comunicações de massa, ele lhes é proposto sob a forma de mensagens formuladas segundo o código da classe hegemônica", tornando-as consumidoras de "modelos culturais burgueses, mantendo-os dentro de uma expressão autônoma própria". Mesmo que a cultura de massa comunique padrões de vida que não fazem parte de sua vida, as massas a assimilam como situações-modelo (MICELI, 2005, p.24). Martin-Barbero (2009, p. 52-56) situa o aparecimento das massas por volta de 1835, cujo conceito é pela primeira vez apresentado na obra de Alexis de Tocqueville, "De la démocratie em Amérique", a partir dos efeitos visíveis da "industrialização capitalista sobre o quadro de vida das classes populares", "[...] que afeta a estrutura profunda da sociedade [...]", ameaçando sua ordem. Compensa-se uma possível desagregação social com a uniformização das massas, através da conversão dos governos (e posteriormente da estrutura industrial) em "órgãos da tendência e dos instintos das massas".

A estrutura da cultura de massa é resultado, portanto, da necessidade, nas sociedades industriais, que diversas entidades têm de se comunicar com toda a população. Para que essa comunicação se efetive, é necessário que haja uma inevitável "adequação à média", que determina alguns dos defeitos identificados no fenômeno de massificação cultural, "[...] entre os quais o conservantismo estético, o nivelamento do gosto pela média, a recusa das propostas estilísticas que não correspondem ao que o público já espera, a estrutura paternalista da comunicação dos valores". Contudo, é incorreto estabelecer que tenha substituído a cultura superior, quando, de fato, apenas possibilitou a estratos populares o acesso a bens dos quais antes estavam segregados, viabilizando o contato com itens que, apesar 
de massificados, tinham valor cultural, como ocorreu pela revolução dos paperbacks, livros de menor formato em brochura, na América do Norte (MICELI, 2005, p.44).

No contexto da indústria de produtos culturais massificados, Eco (2006, p.51) defende a importância dos "homens de cultura" como agentes produtores de políticas e ações culturais mediadoras. A Abril seguiu esta linha ao adotar uma parceria longa e duradoura com professores e intelectuais da Universidade de São Paulo (USP), que, frequentemente, contribuíam nos processos de formação do catálogo das coleções, tradução de obras estrangeiras e redação de introduções e fascículos mediadores da apropriação dos textos. Enquanto parte da intelectualidade discriminava qualquer possibilidade de se produzir uma alta cultura para as massas, os especialistas da Abril oriundos da USP procuraram formas de auxiliar na mediação dos textos para um público sem instrumentação educacional suficiente para apropriá-los. No caso das coleções da Editora, a presença dos "homens de cultura" tem por função mediar a apropriação da cultura hegemônica internacional que simboliza a dependência brasileira, conforme proposto por Miceli.

\subsection{O pulo do gato de Victor Civita}

A alta cultura, em contraposição à cultura de massa, está relacionada com a legitimidade que lhe confere a crítica especializada e a sociedade, como um todo. $A$ crítica utiliza-se de meios considerados autorizados, como colunas em periódicos de boa reputação, publicação de livros de caráter analítico, participação nos círculos sociais e acadêmicos onde se encontra a elite intelectual capaz de ratificar posições que categorizam produtos culturais em diferentes níveis. Já a sociedade, de maneira geral, reconhece e autentica determinados bens pela influência da própria indústria cultural, que lhe internaliza o valor de determinados padrões através de veículos de massa. Nos jornais onde os especialistas analisam determinadas obras, encontramse os dois elementos: a legitimação pela crítica e pela comunicação de massa.

A avaliação que se faz de um produto cultural e sua consequente categorização, todavia, é um elemento subjetivo que se modifica no espaço-tempo, ou seja, o que é autorizado e reconhecido em um determinado tempo histórico ou 
região geográfica pode não sê-lo em outro e vice-versa. Luiz Costa Lima (1978) observa que Decameron, de Bocaccio ${ }^{43}$, surgiu como uma manifestação do que hoje se conhece como literatura de consumo fácil, embora atualmente seja considerado "cultura superior". A própria cultura popular, aqui definida na perspectiva daquela produzida e emergente do povo, nos mais diversos rincões, já foi subjugada e posteriormente legitimada. Do mesmo modo, há bens legitimados pelo nível cultural em que estão inseridos, mas que não resistem a análises sobre sua qualidade estética / artística. A identificação, muitas vezes, se dá pelo contraste entre as "qualificações" da cultura: o "bom" só o é em comparação ao "ruim".

Como forma, mesmo que não explícita, de dimensionar a importância de seus produtos, a Abril utiliza o contraste, subjacente no ponto de vista de seu público-alvo, entre a "alta cultura" e cultura de massas, popular. Esse "pulo do gato", muito associado à figura de Victor Civita, que, como constatado no capítulo 2, optou por uma edição em grande formato e fartamente ilustrada da Bíblia, em contraposição ao lançamento de outra menos suntuosa, foi um trunfo da Editora: produzir obras dentro do circuito da cultura de massas que eram associadas àquelas consumidas pelas elites.

No que tange ao campo editorial, o livro barato, em papel de baixa qualidade, tamanho reduzido e textos de leitura ágil é o que primeiro se associa a um produto massificado. Livros em grande formato, capa dura gravada em dourado com ornamentos e papel de boa qualidade não eram relacionados às massas. Logo, é possível determinar uma configuração: para as classes médias, se o interesse é apenas na leitura ou como passatempo, compra-se o livro de fácil consumo, descartável, procurado pelo menor preço e sem apelo à distinção. Para estabelecer um padrão de diferenciação, adquire-se as coleções da Abril. Em outras palavras, a empresa revolucionou o campo editorial no Brasil não por introduzir o livro ao circuito das bancas de jornais e do grande público, o que já havia sido feito antes, mas por comercializar, nesse circuito, obras de "alta cultura", de "luxo". Indo além: os livros vendidos pela Editora, caso fossem incluídos em outro círculo distributivo, como as livrarias, institucionalizadas e legitimadas para e pela elite econômica e intelectual,

43 Interessante notar que Decameron foi publicado em "Imortais da Literatura Universal", retornando, pelo volume de circulação, à modalidade "popular", ainda que, como literatura legitimada pelo cânone crítico, não tenha deixado de ser considerada "alta cultura". 
poderiam ser categorizadas como "alta cultura", mesmo que apresentassem equívocos no conteúdo, que, certamente, outros livros de cunho erudito igualmente continham. Claro está que o volume, o canal e o público são os condicionantes do "nível cultural" em que as coleções da Abril se inserem.

Luiz Costa Lima (1978) assinala que "[...] a distinção abissal entre as duas modalidades [cultura de massas / alta cultura] pertence meramente ao campo da expectativa de generalidade inconsciente". Quando se desloca um produto que pelo senso comum deveria ser destinado a outro circuito, é natural que se manifeste um estranhamento, uma desconfiança. O papel da publicidade é também romper essas barreiras, condicionando à aceitação o que antes era visto com ressalvas, como poderemos observar nas análises de algumas peças. Estabelece, ainda, enquanto veículo de massa, a relação entre consumo e identidade, fundamental para o efeito persuasivo de seu discurso.

\subsection{A relação entre consumo e identidade}

Os meios de comunicação de massa servem à sociedade, do mesmo modo que a refletem (STEINBERG, 1970). A materialidade e o catálogo dos livros da Abril, conforme abordamos no capítulo anterior, demonstram de que maneira a edição de seus livros na década de 1970 refletia parte da sociedade brasileira naqueles anos. A formação das elites foi alterada com o desenvolvimento das democracias modernas, que as tornou mais diversificadas e menos estratificadas, especialmente nas sociedades ainda em desenvolvimento, como o Brasil, o que promoveu diferentes modos de manifestação cultural (MANNHEIM, 2008). Essa característica possibilitou o fluxo entre diferentes classes de acordo com a alternância de ciclos econômicos, estimulando migrações entre as faixas sociais, o que ocasionou uma espécie de "desconforto" em relação aos novos padrões em que os indivíduos eram inseridos. Todo repertório cultural de hábitos e gostos era posto à prova para que se pudesse constituir a nova posição social. Na busca por elementos de identificação, os objetos associados a classes mais altas, em parte pela influência dos veículos de massa, passam a ser desejados e o consumo desponta como elemento regulador e condicionante. 
A partir dessa perspectiva, ao mesmo tempo em que se deseja fortalecer a posição recém-adquirida, os itens de luxo ou aqueles que estejam vinculados à "cultura superior" tornam-se elementos de classe que passam a compor o arquétipo de bens de consumo considerados restritos a níveis sociais superiores, funcionando como elementos de distinção. No entanto, a própria noção de mercadoria de luxo, exclusiva, pode ser questionável, conforme Appadurai (2008, p. 59), pois a fronteira entre produtos comuns, de massa, e aqueles de luxo é modificada historicamente e, mesmo em um dado momento, "[...] algo que dá a impressão de ser um item homogêneo, em estado bruto e de um campo semântico extremamente restrito, pode se tornar muito diferente no decurso da distribuição e do consumo". A forma, os canais e o público, como se identificou, podem modificar a concepção que se tem de um determinado objeto.

Assim, embora a classificação de um produto esteja submetida ao viés subjetivo e de fundamentações ideológicas particulares aos níveis sociais e culturais, a introdução de novos signos, através da circulação de bens simbólicos, tende a reconfigurar aspectos da identidade pelo processo comercial que rege a indústria cultural. A publicidade e os veículos de mídia são responsáveis pela criação e mediação da rede de significados que são consumidos pelo público e produzidos sob a ótica primordialmente econômica da indústria cultural, que, além do mero entretenimento, procura arquitetar a relação entre consumo e identidade. O público identifica-se com o programa da TV, com o estilo de música do rádio, com a revista que se lê, com o filme do cinema, os livros e a literatura, que, por sua vez, além de serem objetos de consumo, transferem seu prestígio às marcas e produtos que lhes patrocinam e viabilizam. A aquisição de um artigo inserido em uma indústria cultural é a compra não apenas do objeto, mas de toda a rede sígnica que o contempla.

Este processo estrutura a noção de que, numa sociedade de consumo, estar ausente da cadeia de comercialização é perder a capacidade de se identificar ou ser identificado pelos outros. Isso ocorreu, conforme Jhally (1990, p. 195-197), devido ao mercado e à propaganda terem ocupado o espaço vazio deixado pela extinção das antigas formas de pensamento e ideologias após a revolução industrial, que deslocou populações de seus locais de origem para grandes centros produtores urbanos em que a cultura tradicional não tinha lugar e função, substituindo o valor de uso pelo valor de troca. As mercadorias, esvaziadas do sentido antes estabelecido 
pela relação entre artesão e produto, são ressignificadas pelos efeitos da publicidade, cujo poder se manifesta na criação de sentidos para o ser humano, que dele necessita para compreender "[...] o mundo [...] e nós mesmos". Nessa perspectiva, Baudrillard (2009) interpreta a propaganda como um "álibi" da necessidade em fazer sentido e se relacionar com o mundo. O resultado do processo de ressignificação dos objetos fez com que a sociedade deixasse de ser constituída por classes sociais, que se converteram em classes de consumo, nas quais seus devotos seguem a religião da propaganda (JHALLY, 1990), onipresente.

Não é, pois, o livro que distingue, mas, sim, a forma do livro e os sentidos que o discurso publicitário emprega para convencer a audiência de que aquele livro, aquela coleção são superiores aos outros livros e às outras coleções, mas não aos livros e coleções destinados às elites, e sim aqueles considerados de massa, para grande público. Esse fator foi bem caracterizado, no capítulo três, quando apontamos que a coleção "popular" da Abril (Romances Capricho) vendia menos que a coleção "de luxo" (Os Pensadores). De fato, todas as tentativas de comercializar romances populares de baixo custo foram fracassadas ${ }^{44}$, demonstrando que os consumidores, sob efeito do discurso publicitário, dissociaram os livros colecionáveis "de luxo" da Abril dos demais vendidos no mercado de massas.

\subsection{0 público}

A leitura e o consumo de livros sempre foram um hábito muito restrito no Brasil. O elevado índice de analfabetismo entre a população durante muito tempo impediu qualquer tentativa de ampliação do público leitor, que esbarrava em questões estruturais do país, como se vê. Entre 1950 e 1970, a população com mais de 15 anos capaz de ler saltou de 49,4\% para 66,2\%, o que, em consequência, reduziu o índice dos que não possuíam essa aptidão de 50,6\% para 33,8\%45. 0 maior contingente de alfabetizados, entretanto, não resultou em um maior volume de leitores. Consciente do problema, o governo brasileiro, a partir da solicitação de

44 Policiais Abril, em suas duas séries, Ouro e Bronze, não passaram do $12^{\circ}$ volume.

45 O maior volume de alfabetizados concentrava-se nas cidades. As áreas rurais ainda contavam com grande número de analfabetos, assim como as regiões periféricas do país. 
Maria Alice Barroso, diretora do Instituto Nacional do Livro (INL) ${ }^{46}$, passou a veicular, no início da década de 1970, anúncios televisivos de incentivo à formação do hábito de leitura. Elas mostravam

o filme de um garoto que entra numa biblioteca e escolhe um exemplar. Enquanto o folheia, uma série de imagens aparece no vídeo. Da História do Brasil aos grandes personagens do século $X X$ e de velhos conquistadores às conquistas mais recentes. No fim, uma única frase "Em cada livro, um mundo novo" (MAIS..., 1971, p. 57).

Além das propagandas de incentivo à leitura desenvolvidas pelo INL, 0 número de bibliotecas, equipamentos fundamentais para a ampliação do acesso ao livro, apresentou acentuado crescimento durante os anos 1970. Em 1968, existiam, em todo território nacional, 2155 bibliotecas. Esse valor chegou a 2517 em 1971 e saltou para 3519 em 1974, atingindo 5571 em 197947, o que demonstra que em menos de dez anos (1971-1979) o número de bibliotecas no país mais que dobrou. Significativa para esse fenômeno foi a criação do Serviço Nacional de Bibliotecas Municipais, pela lei $n^{\circ} 5.422-A$, de 25 de abril de 1968, "[...] destinado a programar e a promover a instalação e a manutenção, diretamente ou através de convênios, de bibliotecas em todos os municípios brasileiros ${ }^{48}$.

Ainda assim, o reduzido mercado editorial do país da década de 1970 estava concentrado nas publicações feitas nos estados do Rio de Janeiro (Guanabara/Rio de Janeiro) e São Paulo. Esses Estados foram responsáveis por $81 \%$ de todos os títulos editados em território nacional em 1963, com domínio de 95\% da tiragem, sendo que $28 \%$ do total de exemplares era de obras didáticas (MICELI, 2006). Dessa maneira, praticamente todos os livros produzidos no Brasil naquele ano foram impressos por editoras paulistas ou cariocas, num mercado dependente da produção de obras didáticas e de compras governamentais. Em 1972, o volume de

46 Conforme artigo veiculado em Veja, 01 dez 1971, p. 57.

47 Conforme dados do Anuário Estatístico do Brasil (1971, referente a 1968; 1974, referente a 1971; 1976, referente a 1974; e 1983, referente a 1979). Até a década de 1980, os dados incluem apenas as bibliotecas Universitárias, Especializadas, Populares e a Biblioteca Nacional, excluindo as bibliotecas escolares. Para efeito comparativo, foram desconsideradas dos dados referentes a 1979 as bibliotecas escolares (9479) e as definidas na categoria "outras" (781).

48 Texto completo da lei disponível em <https://www.planalto.gov.br/ccivil 03/leis/1950-1969/15422a.htm>. Acesso em: 25 set 2017. 
publicações entre Rio e São Paulo atinge $71 \%{ }^{49}$, uma redução, mas que ainda demonstra a grande concentração da indústria editorial no eixo Rio-SP, que também era o maior mercado consumidor.

O crescimento da alfabetização, o incentivo à leitura através de propagandas e projetos, a ampliação do número de bibliotecas, além de incentivos à indústria de livros e de suprimentos ${ }^{50}$, ampliou a capacidade produtiva brasileira no ramo editorial, mas o acesso permanecia restrito devido ao valor das publicações e pouca quantidade de livrarias existentes no país. A mobilidade social que se apresentou especialmente na década de 1970, com o crescimento econômico, foi determinante para a expansão do mercado de massa editorial brasileiro, submetido à dinâmica industrial de produção e circulação de bens culturais, por ter proporcionado a uma parcela da população a melhora nos rendimentos, de forma que houvesse um excedente a ser investido em mercadorias não essenciais à subsistência.

A partir do exposto, compreende-se que o mercado de massa de bens culturais no Brasil da década de 1970, no que se refere à circulação de livros e discos, era um segmento de classes médias, por serem produtos vendidos a preços mais elevados; portanto, menos acessíveis que programas de televisão, cinema, rádio, entre outros, concentrado nas grandes cidades, particularmente no Rio de Janeiro e São Paulo. Considerados gêneros supérfluos, o restrito orçamento das classes baixas não lhes permitia tais "luxos", como a compra dos livros da Abril, pois havia outras prioridades, e seu consumo cultural era destinado a artigos de menor valor ou gratuitos.

A "pesquisa sobre o padrão de vida do trabalhador paulista" (O SINTOMA..., 1969), realizada pelo DIEESE (Departamento intersindical de Estudos Estatísticos e Socioeconômicos), informa que, em 1969, o trabalhador havia perdido $60 \%$ de seu salário real em relação a 1958. Durante os anos 1970, o percentual do orçamento gasto por esta parcela da população com despesas de "leitura" caiu, conforme o

\footnotetext{
49 De acordo com o IBGE, baseado em dados do Serviço de Estatística da Educação e Cultura. Disponível em:

$<$ https://seculoxx.ibge.gov.br/images/seculoxx/arquivos download/cultura/1974/cultura1974 aeb47.p df $>$. Acesso em: 18 set. 2017.

50 Em 1967 foi promulgada a imunidade tributária para livros e em 1977 foi instituída a política integrada do livro.
} 
DIEESE, dos já reduzidos 0,4\% em 1969 para 0,35\% em 198251, o que significa que apenas a família que ganhasse mais de quatro salários-mínimos em 1970 (Cr\$2916,80 em São Paulo) poderia, investindo 0,4\% de seu orçamento em "leitura", adquirir um exemplar de Os Imortais da Literatura Universal, vendido a $\operatorname{Cr} \$ 10$. O valor de investimento em "leitura" proposto pelo DIEESE é uma média e as famílias podem optar por gastar mais (ou menos) que o valor médio em livros e periódicos, de acordo com suas necessidades.

As elites intelectuais e econômicas, situadas em outra esfera social e cultural, além de terem acesso a produtos de maior valor, em geral recusam os itens populares, massificados, que veem como "inferiores". São os "apocalípticos", como define Umberto Eco (2006): associam bens oferecidos às massas como degeneradores culturais, símbolos da decadência do conhecimento erudito antes subordinada às classes altas. O fato de se afirmar que o consumidor de livros editados pela Abril não era composto pelas classes baixas e altas não significa que tais estratos se abstivessem de consumir as coleções bibliográficas da Editora, mas, sim, que não foram eles o público prefigurado durante planejamento comercial das obras $^{52}$.

Os livros completos e colecionáveis da Abril são lançados apenas em 1970, auge do "milagre"; porém, o sucesso dos fascículos ocorria há cinco anos, como vimos anteriormente. É importante que se ressalte, no entanto, que os fascículos, espécies de livros "a prestações”, como definiam os Civita, por serem publicações de reduzido número de páginas, eram mais baratos, sendo compatíveis com o orçamento do consumidor das classes médias para gastos culturais. O "milagre" produz uma nova classe com condições de adquirir não apenas os fascículos, mas os livros completos, que custavam cinco vezes mais ( $\mathrm{Cr} \$ 10$ de Os Imortais da

51 DIEESE. Comparação das estruturas orçamentárias nas últimas décadas. Disponível em: <https://www.dieese.org.br/metodologia/pof3.xml>. Acesso em: 25 set. 2017.

52 Havia diferenças de público entre os temas das coleções bibliográficas e entre livros e fascículos. Entre os livros, as coleções dedicadas à literatura eram consumidas preponderantemente pelas classes $\mathrm{B}$ e $\mathrm{C}$, enquanto as de livros de maior interesse no meio universitário, como "Os Pensadores" e "Os Economistas", esta de 1982, tinham um bom público da classe A. Já os fascículos de enciclopédias apresentavam bom volume entre a classe D. Apesar das variações, as classes $\mathrm{B}$ e $\mathrm{C}$, em todos os casos, estavam à frente das outras no perfil de consumo. Os dados são relativos ao começo da década de 1980, publicados por Miceli (2005). 
Literatura Universal contra Cr\$2 de "Grandes Personagens da História Universal", editados em 1970).

Para o fenômeno dos livros da Abril, o panorama é relevante, como pudemos observar. $O$ expressivo desenvolvimento da economia nacional ampliou e enriqueceu a classe social intermediária no Brasil, bem como alterou seu mecanismo de ascensão após o Regime Militar, tendo sido determinante para a demanda por educação que se acentuou nos primeiros anos da década de 1970. Se antes, de acordo com Romanelli (1991), a promoção social ocorria através de poupança, investimento em pequena empresa ou negócio próprio, reprodução do capital e nova poupança, passou, a partir do modelo econômico então adotado, a acontecer através da ascensão dos funcionários nas hierarquias empresariais. $O$ deslocamento hierárquico requeria empregados qualificados para ocuparem funções cada vez mais técnicas, bem como o próprio acesso às organizações tornava-se difícil sem que se alcançassem níveis mais altos de educação formal. Os produtos culturais da Editora atendiam a duas necessidades, portanto: primeiro, como símbolo de "status cultural para a classe média em ascensão, especialmente em países onde ainda são poucos os livros de texto e não existe movimento editorial intenso", conforme indica Pedro Paulo Poppovic, diretor de fascículos da Abril Cultural (RANGEL, 1974); segundo, como ferramenta educacional, pois as coleções dotam seus consumidores de instrumentos de capacitação que representarão uma vantagem na competição por novas posições profissionais, em uma concorrência por vagas de emprego.

Como as classes médias eram numerosas e com diferentes perfis de acordo com sua posição, as pesquisas de público foram fundamentais para que a Editora pudesse produzir o discurso publicitário mais efetivo para a persuasão do público específico para cada coleção, bem como o veículo mais adequado para atingi-lo. Thomaz Souto Correia, Vice-Presidente de Revistas da Abril em 1980, destaca que a pesquisa de público, para auferir o interesse de diversos segmentos, foi uma grande novidade na década de 1970 (CORREIA, 1987). O período representou, além do mais, a introdução dos sistemas computadorizados, que facilitou e agilizou o processo de pesquisas. Infelizmente, não obtivemos, devido à recusa dos responsáveis pelo Departamento de Documentação da Abril, o acesso às pesquisas 
realizadas para a especificação do perfil de potenciais consumidores de cada coleção.

Dentro do perfil de público, conforme esclarece Fernando Almada ${ }^{53}$ (ALMADA, 1975, p. 239), há diferenças entre "[...] o comprador final, que adquire algo para seu próprio uso"; aquele que adquire o produto para um terceiro e também o "influenciador da compra". Em relação à frequência de aquisição, identificam-se, conforme a nomenclatura inglesa, três grupos de consumidores: 1) os heavy-users, composto pelos clientes frequentes e fiéis; 2) os medium-users, aqueles que consomem com menos frequência que o primeiro grupo, mas ainda de maneira significativa; e 3) os light-users, compradores eventuais, de "de-vez-em-quando". Há também os clientes potenciais, aqueles que poderiam se tornar consumidores, mas, "[...] por alguma razão não o fazem". Cada uma destas categorias de público "[...] exige tratamento específico e sua eleição como audiência-alvo depende da perspectiva de resposta e dos objetivos do anunciante". Os heavy-users, embora constituam apenas $20 \%$ do total de consumidores, respondem por $80 \%$ das compras, o que os faz terem a preferência das empresas em suas campanhas publicitárias.

No caso dos livros da Abril, havia o comprador já fiel à dinâmica das coleções de fascículos, mas que não estava acostumado a adquirir volumes completos. Assim, ao mesmo tempo em que eram heavy-users dos fascículos, formavam parte do público potencial para as coleções bibliográficas, que também era constituído por indivíduos que não colecionavam os fascículos, mas que poderiam ter interesse em colecionar livros.

Os influenciadores de compra são uma audiência-alvo à parte e devem ser sempre considerados (ALMADA, 1975, p. 241). Os professores podem influenciar seus alunos a comprarem determinados livros, obrigatórios ou não (lembremos, novamente, da carta de dona Martha, cujo professor da filha indicou um fascículo publicado junto à Veja como fonte de pesquisa para os alunos). Igualmente importantes são os críticos literários, que têm como leitores heavy-users de livros,

53 Almada trabalhou, nos anos 1970, como diretor de criação das agências McCann Erickson Publicidade, Standard Propaganda, Mauro Salles/Interamericana e J. Walther Thompson, algumas das maiores empresas do setor a operar no Brasil naquele período. 
mas pouca influência sobre o público como um todo, diferentemente de colunistas de assuntos gerais, duas categorias para os quais a Abril tinha por hábito remeter amostras de suas edições. Há, ainda, o "líder de pequenos grupos - família, clube, vizinhança, escritório, escola - sempre responsável pelo primeiro degrau no decurso da informação", comunicando às pessoas próximas de seu círculo social o que "viu, leu e ouviu, quase sempre com um toque de interpretação pessoal". Almada cita também como grande influenciador o "balconista de livraria", o que, no caso das edições da Abril Cultural, é substituído pelo jornaleiro.

A correta identificação do público consumidor está relacionada com a estratégia de precificação que a Editora Abril impôs às suas coleções. Compreendendo o consumidor, é possível conhecer seu poder de compra, o valor de seu excedente orçamentário para investimento em produtos culturais e quanto estaria disposto a gastar, desse excedente, para adquirir os livros da Editora. Em conjunto, o preço, fácil disponibilidade (venda em bancas) e massiva propaganda tornavam as coleções objetos de desejo pelo público-alvo quando eram publicadas. Antes mesmo de cada produto chegar às bancas, o consumidor já as conhecia e sabia, como, quando e onde poderia encontrá-las.

\subsection{O preço do livro}

A propaganda e os veículos de massa são ferramentas fundamentais na constituição do que se compreende como a indústria cultural. As coleções da Abril, como elementos pertencentes a esse circuito de produção dos bens simbólicos, são produzidas "[...] a baixo custo e com rentabilidade dos investimentos, buscando, consequentemente, a máxima extensão de mercado, cuja sanção é fundamental para a definição do produto cultural" (SEVERINO, 1986, p. 95).

O domínio de quase toda a cadeia produtiva, o modelo de coleções e as altas tiragens permitiram à Abril cobrar preços muito abaixo do que normalmente custariam livros com o mesmo perfil. No entanto, apesar de terem um baixo preço de venda, não eram os mais baratos disponíveis, principalmente se considerada a circulação em bancas, como vimos. A propaganda teve um importante papel na 
percepção de valor dos livros perante o público, que os considerava "baratos" pelos "benefícios" que ofertavam, mas não se pode desconsiderar o impacto que a marca "Abril Cultural", pelo seu prestígio, tradição e nome, promoveu como "prova de apoio"54 à compra.

A fidelidade à marca ou à série, nas indústrias culturais, é um ativo a ser conquistado, pois, em uma economia de mercado, qualquer nicho com lucratividade acima da média atrairá, sem dúvida, um grande número de concorrentes. Quando a empresa pioneira detém tecnologia ou modelos que constituam barreiras de entrada aos concorrentes, ela consegue se manter em posição de destaque por mais tempo. Caso as barreiras sejam frágeis, a competição se acirrará e inúmeros outros agentes começarão a produzir o mesmo item; se não igual ou melhor, ao menos mais barato. A qualidade das edições, da impressão, do papel; a parceria com jornaleiros e baixo preço são estratégias que a Abril empregou para se proteger de outras editoras com interesse no negócio de coleções fasciculares e de livros. Tanto que, durante a década de 1970, apenas a Editora Três, formada por dissidentes da Abril, como observamos, ingressou no mercado de coleções bibliográficas vendidas em bancas, sem, no entanto, conseguir tomar o lugar dos Civita.

Ao analisar o preço do livro no Brasil dos anos 1970, fica evidente a relevância da propaganda para o bom volume de vendas das obras da Abril. Mesmo inscrevendo-se no âmbito dos produtos culturais de massa de baixo custo e sendo mais baratas que a média das edições convencionais, comercializadas em livrarias, havia oportunidades de se adquirir livros de qualidade a preços módicos. Uma delas eram as liquidações, realizadas para reduzir os encalhes e estoques em livrarias. Carlos Drummond de Andrade (ANDRADE, 1970, p. 8), em uma crônica publicada no Jornal do Brasil em agosto de 1970, relata a surpresa, que Ihe vinha na forma de um "soco-na-cara", e a frustração "de ver pilhas de livros de boa qualidade vendidos a preço 'de banana'": "por toda a cidade há portas e cartazes chamando para a torração de volumes a 2 cruzeiros ou até menos. O livro que custava 12 a 15

54 Almada (1975, p. 243) indica que a "prova de apoio" é "o argumento final ou a informação complementar que dá credibilidade à promessa [feita pela propaganda]". Entre as provas de apoio, estão o "[...] próprio nome do autor, seu prestígio, currículo, posição ocupada, autoridade no assunto, popularidade. Ou então no endosso de quem tenha aquelas mesmas condições, numa espécie de testemunho. O sucesso do livro é prova de apoio. Até o prestígio, a tradição e o nome da editora podem ter esse peso. Também são provas de apoio as informações sobre uso ou adoção em escolas ou outras entidades de renome". 
cruzeiros baixou a quase zero". O poeta, dando voz às "pilhas de livros", ressente-se que fossem negociados a preços irrisórios, desvalorizando o trabalho do autor, que havia feito tudo para produzir um volume "belo e digno de leitura". Drummond demonstra em sua crônica conhecer a dinâmica da oferta e procura que atingia também os bens culturais, ao indicar que havia apenas cinco mil leitores em todo Brasil para obras consideradas "de melhor qualidade". Ainda assim, preferiu deixar a "explicação" para "a página de assuntos econômicos".

Em uma iniciativa do Estado em reduzir artificialmente o preço dos livros, no ano de 1970, o Instituto Nacional do Livro (INL) fechou parcerias com diversas editoras nacionais ao comprar parte das tiragens e distribuir os exemplares a bibliotecas públicas. No ano seguinte, já com algumas obras literárias e acadêmicas editadas $^{55}$, o valor girava em torno de Cr\$10 para os livros de ficção, em associação com editoras renomadas como José Olympio, Civilização Brasileira, Agir, Melhoramentos, Sabiá, Globo, entre outras, e Cr\$25 para os universitários, editados em parceria com a Universidade de São Paulo (USP) (DIAS, 1971).

Mesmo no mercado convencional de obras comercializadas em livrarias, não eram raras as opções mais baratas (embora com acabamento e formato inferiores). Em agosto de 1971, por exemplo, quando cada um dos dois volumes quinzenais de "Imortais da Literatura Universal" custava Cr\$10 nas bancas de jornais, o valor para livros de ficção em um volume (em geral, brochuras) era entre Cr\$3 e Cr\$22, conforme preços indicados no suplemento literário Jornal do Brasil (RJ) daquele mês. Os livros provenientes das parcerias do INL eram comercializados entre Cr\$5 (De uma Noite de Festa, de Joaquim Cardozo, publicado pela INL/AGIR em brochura de 150 páginas, no formato $12 \mathrm{~cm}$ por 18,5 cm) e $\mathrm{Cr} \$ 12$ (A Casa Verde, de Mario Vargas Llosa, publicado pela INL/Sabiá em brochura de 380 páginas, no formato $14 \mathrm{~cm}$ por $21 \mathrm{~cm}$ ). Livros de bolso populares da Coleção Saraiva, em brochura de pequeno formato com papel de baixa qualidade, custavam $\operatorname{Cr} \$ 3$. As Edições de Ouro (Tecnoprint) ofereciam clássicos, como algumas obras de Kafka, por valores entre $\operatorname{Cr} \$ 2,50$ ( $A$ Metamorfose, $12 \mathrm{~cm}$ por $20 \mathrm{~cm}, 137$ páginas) a $\operatorname{Cr} \$ 6$ ( $A$ Colônia Penal, $11 \mathrm{~cm}$ por $16 \mathrm{~cm}, 283$ páginas).

55 Não se incluem dados sobre os livros didáticos, obras com maior contingente no projeto. 
Percebe-se, portanto, que os livros da Abril não eram os mais baratos disponíveis no mercado (embora, certamente, os mais em conta se considerados seu acabamento e formato). A propaganda valorava suas edições e convencia o público de que o custo era atrativo, considerados os "benefícios" que ofereciam. Entre as editoras de fascículos, a Abril se esforçava para manter os valores baixos, mesmo em um período de inflação. Em carta ao Jornal do Brasil ${ }^{56}$, um leitor de Georama e Naturama, publicadas pela Editora Còdex, reclamava de seus constantes aumentos de preço, enquanto a Editora Abril mantém os preços "fixados por longos períodos" (ROTINA..., 1968).

Avaliada a situação do preço do livro no início da década de 1970, compreende-se que não foi este o fator primordial de motivação à compra das coleções bibliográficas da Abril Cultural. Sem dúvidas, a onipresente propaganda de divulgação feita a cada lançamento foi um fator fundamental para a ampla circulação que os volumes alcançaram, tendo em vista principalmente o gênero de texto que veiculavam. Compreender essa dinâmica é fundamental para interpretar o fenômeno da venda em massa de livros em bancas de jornais pela Editora.

\subsection{As propagandas}

A publicidade "não mais se trata de uma lógica do enunciado e da prova, mas sim de uma lógica da fábula e da adesão", da crença. Deixou o simples discurso informativo sobre o público para ir mais fundo, agindo em seu inconsciente, convencendo-o de que há uma instância social que "[...] aceita informá-lo sobre seus próprios desejos, preveni-los e racionalizá-los" (BAUDRILLARD, 2009, p.175-176). poder do discurso publicitário reside na crença que nele se deposita, ainda que, objetivamente, não se creia no produto. Nesse sentido, o discurso, em muitos casos, se torna mais importante que a própria mercadoria.

A ampla divulgação de novas edições não era comum, devido, principalmente, ao alto custo envolvido, que era inviável para publicações individuais e de baixa tiragem, como era o padrão no mercado editorial brasileiro. A campanha para uma nova coleção chegava a custar, em 1974, Cr\$10 por exemplar que se desejava 
vender do primeiro número, conforme indica Pedro Paulo Poppovic (RANGEL, 1974). Assim, se o plano era vender 100 mil exemplares do volume inaugural, o investimento em peças de divulgação poderia chegar a um milhão de cruzeiros, o que apenas uma grande empresa, como a Abril, poderia financiar.

Existia, ainda, uma outra barreira: a da visão de sacralidade em que permanecia envolvido o livro, visto como um artigo nobre e elitista, não sujeito a ser propagandeado como um produto qualquer, o que impedia que algumas editoras e autores aceitassem inseri-lo no circuito produtivo da indústria cultural de bens simbólicos comercializados para as massas. Almada considera esse conceito "elitista" e defende que

o livro é um produto, como os detergentes, os automóveis, os desodorantes e tantos outros exemplos disponíveis.

A livraria é uma loja, uma casa de comércio, um ponto de venda como os supermercados, padarias, farmácias e quitandas.

A infeliz rotulagem do livro como produto nobre é elitista e preconceituosa, sobretudo quando há tantas oportunidades para a massificação da informação e da cultura.

O editor é um industrial, como os fabricantes de Coca-Cola, e o dono da livraria é um comerciante, como o dono do Peg-Pag.

Esta colocação inicial do problema é indispensável para a discussão profissional e descontraída dos aspectos promocionais e publicitários da indústria e do comércio do livro, dos mais fascinantes produtos que existem no mercado (ALMADA, 1975, p. 233).

Almada, um publicitário, e, portanto, falando a partir da posição de sua classe, deixa transparecer que o deslocamento do livro de seu lugar sagrado, de veneração limitada ao pequeno grupo de iniciados, para o espaço profano da cultura de massas, é um recado, não isento de interesses, aos editores para que invistam na promoção de seus livros. Mas sua defesa do livro como produto, ainda que o rebaixe de bem cultural a bem de consumo, colabora, sem dúvida, para estimular uma nova visão sobre o mercado, na perspectiva em que a Abril habilmente inseriu suas publicações. Diferentemente de editoras tradicionais, topou falar com um público com quem os demais editores não se comunicavam e utilizou seu poder econômico para arriscar-se na aposta de que existia uma demanda latente por livros (não necessariamente pela leitura) no país.

Desde o lançamento de A Bíblia Mais Bela do Mundo, a Abril sempre procurou abrir espaço no mercado para suas publicações culturais com ampla oferta de peças promocionais. Entre 1966 e 1967, a agência que criou as campanhas publicitárias 
das coleções foi a PDP Propaganda (Promoção, Divulgação e Produção); e, a partir de 1967, a Standard Propaganda, uma das mais tradicionais agências brasileiras, criada em 1933, tornou-se responsável pela produção e divulgação das campanhas. A relação da Abril com as agências era tão estreita que, segundo informa Alzira Alves de Abreu e Christiane Jalles de Paula em seu Dicionário histórico-biográfico da propaganda no Brasil, o publicitário Sergino de Souza criou para a Editora as coleções Os Pensadores, Gênios da Pintura e Mitologia, sendo que pela peça Londres sob bombardeio, desenvolvida para divulgar a coleção História do século $X X$, ganhou o prêmio "Lâmpada de Ouro", da ABP (Associação Brasileira de Propaganda), conforme detalharemos mais à frente.

A Abril sempre foi inovadora em suas promoções e já em 1964, ainda antes das publicações culturais, portanto, o lançamento da revista Máquinas e Metais surpreendeu pela inovação na campanha. O primeiro exemplar da revista, distribuída gratuitamente nas indústrias, foi entregue dentro de um cilindro de metal, remetendo ao título do periódico e segmento de seu público, com um selo onde se lia "Mais um novo produto da indústria metalúrgica" (fig. 36). A promoção foi efetiva, pois "em poucos dias os círculos interessados souberam da existência do novo veículo" (NOGUEIRA, 1964, p. 6). 
Figura 36 - Peça de lançamento de Máquinas e Metais - 1964

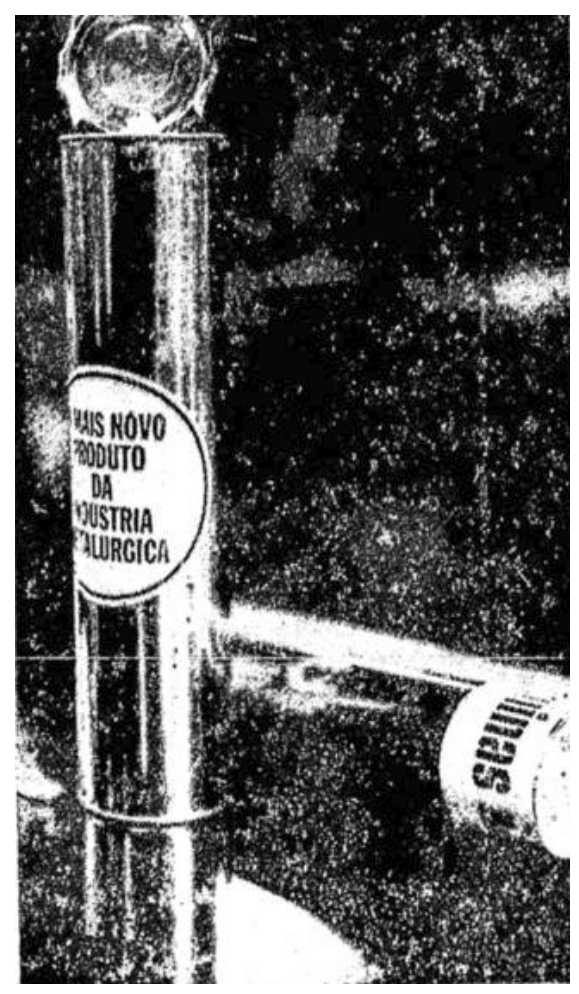

Fonte: Folha de São Paulo, 18 jul. 1964, p. 16. Disponível em: <http://acervo.folha.uol.com.br/fsp/1964/07/18/2/>. Acesso em: 12 out. 2017.

O livreto Comunismo - de Karl Marx ao muro de Berlim foi outro exemplo em que a propaganda se refletiu em grande procura pelo produto. Funcionários de livrarias em São Paulo (a edição foi vendida em bancas e livrarias) informavam que a procura pelo volume estava muito alta mesmo antes de estar disponível para venda. Uma das estratégias de promoção era a colagem de cartazes em tapumes da cidade, onde se via em grande formato o símbolo comunista da foice e do martelo em vermelho, abaixo da palavra "CUIDADO".

Em 1968, mais um ousado lançamento: para divulgar Grandes Compositores, uma coleção de fascículos acompanhados de discos abrangendo os maiores nomes da música clássica, a Abril promoveu dois concertos na cidade do Rio de Janeiro, ambos realizados pela Orquestra Sinfônica Nacional, regida pelo maestro John Neschling e com solos de Jacques Klein. O primeiro espetáculo aconteceu na Sala Cecília Meireles, dia 09 de novembro, às 16h, e o segundo no Auditório da TV 
Globo, no dia seguinte, às 10h. Foram executadas a Sinfonia do novo mundo, de Dvořák, e o Concerto no 1 para piano e orquestra, de Tchaikovsky.

No ano seguinte, foi publicada a coleção Arte nos Séculos. Afora as peças de lançamento, a Abril apostou em outra estratégia: alugou um estande na X Bienal de Arte de São Paulo e ofereceu aos visitantes o primeiro volume da coleção, que foi encadernado com os 14 fascículos já publicados. Entre os compradores do volume, foi sorteada uma obra do artista plástico nipo-brasileiro Yutaka Toyota, premiado na edição daquele ano.

A Abril soube utilizar, além de seu poder econômico, o poder midiático de que dispunha por possuir diversas revistas segmentadas, nas quais podia divulgar os próprios produtos para o público adequado a cada um deles. Um caso, de certa forma até curioso, é identificado em uma promoção da Revista Intervalo, periódico da empresa voltado ao mundo televisivo e de celebridades. A "Copa Mancada" foi uma seção da revista em que, durante a Copa do Mundo de 1970, foram publicados equívocos cometidos pelos narradores de futebol, anotados e enviados à redação pelos leitores. Os dois locutores com mais erros ganharam uma coleção da Enciclopédia Conhecer e os participantes com mais pontos receberam duas bicicletas Monark. Os vinte próximos colocados no ranking de contribuições foram premiados com exemplares de Papillon e a Abril aproveitou a divulgação dos resultados para promover o livro através de uma pequena sinopse.

Observa-se, pela variedade dos exemplos apresentados acima, quão diversas eram as estratégias utilizadas pela Editora para divulgar seus produtos culturais, dependendo do perfil de consumidor a quem queria alcançar. Quando as coleções de livros começaram a ser lançadas, a Abril já possuía, portanto, vasta experiência na promoção de suas edições, o que lhe facilitou a arriscada aposta, devido ao valor de investimento envolvido, na produção de volumes completos comercializados em bancas de jornais. Esse know-how, assim como a profissionalização do setor publicitário e o incremento das pesquisas de público, foram basilares para a eficácia das propagandas que se seguiriam a partir de 1970. 


\subsection{As coleções da Abril Cultural: a publicidade e seu discurso}

As campanhas publicitárias para os lançamentos de novos produtos abrangiam, de maneira geral, o período de dez dias antes e depois da estreia nas bancas (RANGEL, 1974). Quase sempre de grande alcance e envolvendo toda diversidade de mídias possíveis, o resultado era compensador pela alta vendagem que obtinham os primeiros números, mas o elevado custo envolvido não permitiria que se mantivesse a propaganda constantemente ativa durante os dois ou mais anos pelos quais se prolongavam as coleções. Nesse aspecto, o colecionismo, de que tratamos anteriormente, tem papel fundamental: à Editora, bastava convencer o público de que comprasse os primeiros fascículos, de maneira que se despertasse o interesse pela coleção. A partir de então, a própria dinâmica de se colecionar fazia com que um determinado número de leitores permanecesse fiel, adquirindo cada exemplar subsequente durante o período da coleção, sem a necessidade de nova promoção. Os consumidores que não continuassem acompanhando a coleção eram compensados pelos que compravam exemplares avulsos, de seu interesse, sem, no entanto, ter o desejo de formar o conjunto da série.

Apesar da diversidade de veículos e canais utilizados pela Abril em suas propagandas, poucas são as peças fora do circuito impresso de periódicos, panfletos, folders e cartas comerciais disponíveis para consulta. Optamos, desse modo, por dar ênfase a análises de promoções realizadas através destes meios. Ainda assim, foi possível acessar a campanha em vídeo que deu a Sergino de Souza o prêmio da ABP em 1974 (Fig. 37) ${ }^{57}$. Nesta peça, pessoas encontram-se em um bar (um pub na Inglaterra durante a Segunda Guerra Mundial), enquanto Winston Churchill discursa aos ingleses preparando-os para uma possível invasão alemã ${ }^{58}$. Após alguns segundos de discurso, ouve-se uma sirene e barulhos de

57 Há outras peças, raras, referentes a coleções de fascículos em vídeos disponíveis no site YouTube (www.youtube.com.br).

58 O discurso ficou conhecido como "Never was so much owed by so many to so few" e foi proferido em 29 de agosto de 1940. O fragmento utilizado na peça é este: "The gratitude of every home in our island, in our Empire, and indeed throughout the world except in the abodes of the guilty goes out to the British airmen who, undaunted by odds, unweakened by their constant challenge and mortal danger, are turning the tide of world war by their prowess and their devotion. Never in the field of human conflict was so much owed by so many to so few. (Prolonged cheers.) All hearts [...]". A fala completa está disponível em <https://www.theguardian.com/century/19401949/Story/0,128255,00.html>. Acesso em: 14 out. 2017. 
bombardeio. Os frequentadores fogem enquanto as luzes do local se apagam. No decorrer da peça, com 45 segundos de duração, o narrador, em off, apresenta a coleção: "Século XX: dramas que traumatizaram gerações. 'História do Século XX', todos os fatos que influenciam sua vida hoje estão na 'História do Século XX'. Nas bancas o primeiro fascículo".

Em outra campanha televisiva, para divulgação do relançamento da Enciclopédia Conhecer (Série Azul), de abril de 1968, o tom é diferente daquele sombrio bombardeio do pub inglês. O filme inicia-se com a imagem de uma banca de jornais, onde estão pendurados diversos exemplares de Conhecer. Diversas crianças correm, com um exemplar da enciclopédia em mãos, e reúnem-se em um banco de alvenaria, onde folheiam o fascículo. Na sequência, um pai, acompanhado de seus filhos, um menino e uma menina, chega à banca e analisa o produto. A cena corta para uma jovem sentada em um sofá, provavelmente em uma sala de estar, lendo o fascículo como se fosse uma revista, com a enciclopédia, encadernada, à mostra na estante ao fundo. Encerra-se o vídeo com vários pais indo à banca adquirir Conhecer e realizando a leitura com seus filhos. Não se vê nenhuma mãe realizando a compra. O narrador, em off, informa: "Em setembro de 1966, o pai de Maria Lúcia Amorim começou a colecionar Conhecer. Hoje, ela é a primeira da classe. Seria uma injustiça se você não desse esta oportunidade a seus filhos. Por isso, Abril Cultural lança 'Conhecer Série Azul', a reedição, fascículo por fascículo de 'Conhecer', a mais completa enciclopédia semanal. Agora, você também poderá aprender, como se estivesse lendo uma revista, um mundo de conhecimentos. 'Conhecer Série Azul' já está nas bancas por apenas oitenta e cinco centavos cada fascículo. Não perca essa nova oportunidade de colecionar 'Conhecer Série Azul'. Um lançamento Abril Cultural".

Como podemos observar, há, no discurso da peça, algumas passagens que se repetiram nos primeiros anos do comércio de fascículos. Por exemplo, a ênfase no fato de que o fascículo era uma maneira de se "aprender como se estivesse lendo uma revista" foi uma maneira que a Editora encontrou de persuadir o públicoalvo, reticente à compra de enciclopédias, vistas como herméticas, difíceis, complexas, a adquirir o "conhecimento em fatias", vendido de forma fracionada durante cada semana. A oportunidade de tornar os filhos "primeiros da classe" também foi uma estratégia de convencimento para este tipo de produto. Na imagem, 
tem-se a figura onipresente do pai de família, responsável pela educação e compra da coleção, outro recurso muito presente nas campanhas.

As propagandas televisivas foram constantes nas coleções da Abril, especialmente as enciclopédicas, de público mais amplo, pelo alcance que suas transmissões obtinham já naquela época. É importante notar que a televisão foi um veículo que cresceu consistentemente durante a década de 1970, fazendo com que se concentrassem neste canal boa parte dos investimentos publicitários, que passaram "[...] de 39,6\% em 1970 para 57,8\% em 1980 [...]" (MICELI, 2005, p. 221). Ainda assim, a mídia impressa era um valioso meio para divulgação de produtos culturais, especialmente aqueles também impressos, por atingir o consumidor já habituado à prática da leitura. 
Figura 37 - Peça televisiva para divulgação da coleção História do Século XX
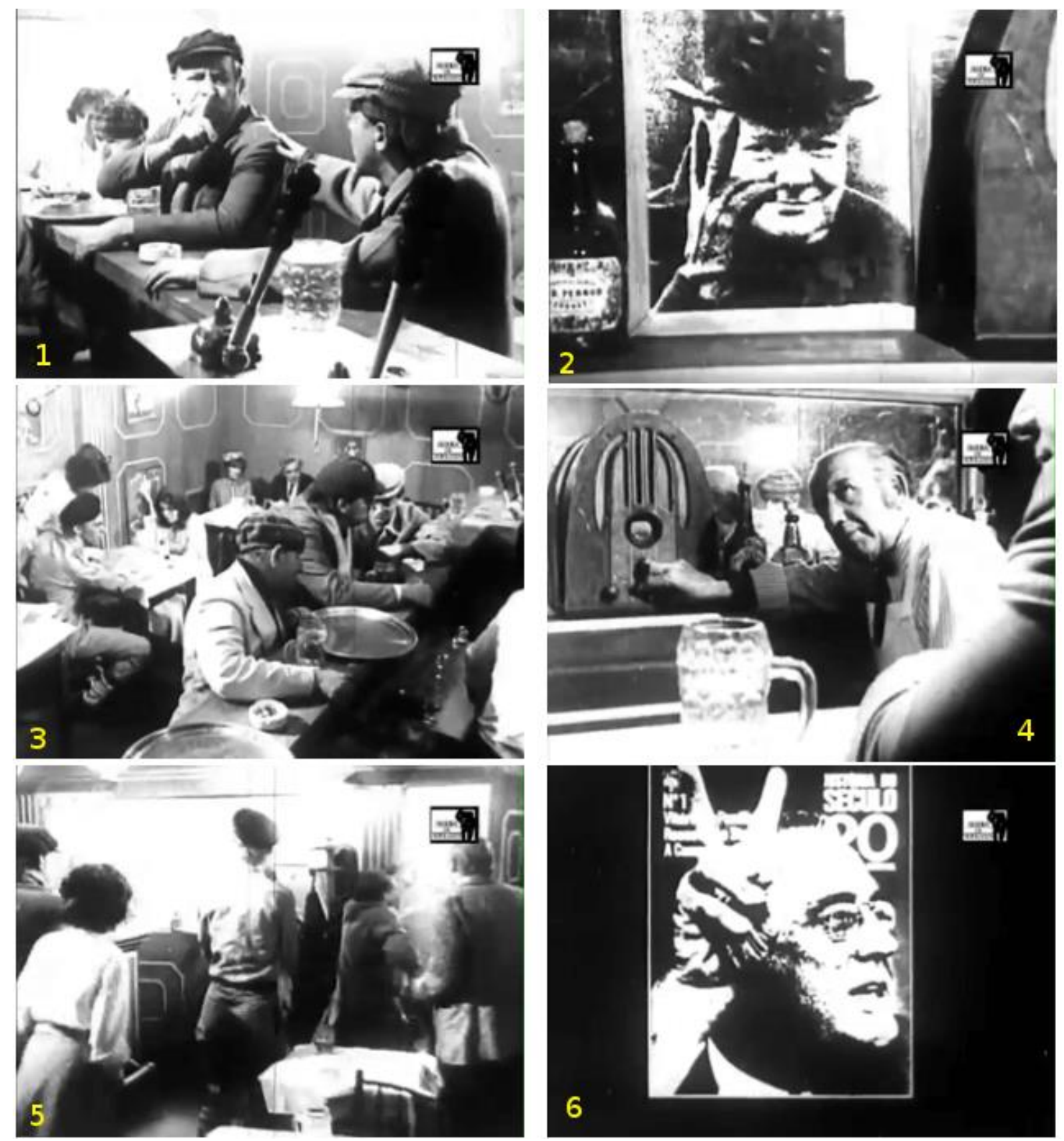

Fonte: ZAPPIENS. Disponível em: <www.zappiens.br>. Acesso em: 25 mar. 2015. 


\subsubsection{Os Imortais da Literatura Universal}

Imortais da Literatura Universal inaugurou a série de coleções de livros que a Editora Abril, através de sua divisão, a Abril Cultural, lançaria durante a década de 1970. Sua divulgação utilizou vários canais, como "[...] 'Out-doors', anúncios em jornais e revistas, mala-direta, TV, cinema e rádio" (XAVIER, 1971, p. 6). O públicoalvo era composto por leitores não habituados à literatura de cunho erudito, vista aqui em contraposição aos textos leves, estruturalmente simples e ágeis dos romances populares. Já no primeiro volume, Dostoiévski, há, logo de início, duas barreiras a se romper: 1) o fato de a literatura russa ser, em 1970, praticamente desconhecida no Brasil, com raras traduções de seus autores fundamentais; 2) aos que em algum momento tiveram contato com a obra de Dostoiévski ou outros autores da coleção, era necessário desfazer o estigma de obras herméticas, inacessíveis, embora, de fato, parte dos textos fossem dotados de construção semântica complexa.

Ao analisarmos a figura Figura 38, um panfleto de lançamento da Coleção, provavelmente veiculado como mala direta ou inserido junto a alguma revista da Editora $^{59}$, constata-se, a princípio, o destaque que os volumes têm em conjunto, com a lombada e suas dourações expostas, como ficariam em uma estante. A força dessa representação remete às considerações anteriormente feitas sobre 0 consumo dos livros para distinção e a importância que havia em se editar as obras em capa dura e com inscrições douradas, como é o arquétipo do livro erudito, vinculado às elites, no imaginário popular. O primeiro volume, seu fascículo e a coleção iluminam um fundo propositalmente escuro. Os textos são separados, referindo-se, à esquerda, junto ao livro, ao enredo do romance e, à direita, junto ao fascículo, a importância deste complemento para a compreensão da obra.

A descrição da história de Irmãos Karamázov poderia referir-se a praticamente qualquer outro romance, desconsideradas as particularidades como nome dos personagens e condições históricas da Rússia czarista. Expressões

59 O Departamento de Documentação (DEDOC) da Editora Abril separa estas peças em pastas, identificadas unicamente pelo nome da coleção e data de lançamento. Não há nenhum tipo de informação adicional, mas, pelo formato, acredita-se que tenha sido uma campanha veiculada junto de algumas revistas da Editora, em seu miolo, ou por meio de mala direta ao público-alvo. 
clichês como "cheias de paixões e ódios", "você vai entrar no coração de cada personagem", "cada linha vai ser uma aventura" retratam a necessidade que os redatores da peça sentiram em ambientar a obra de Dostoiévski para o leitor de outros tipos de romance, a que estavam habituados. As informações referentes ao fascículo cuidam de tornar mais familiar o autor, pois a biografia revelará "o verdadeiro Dostoiévski. Um homem profundo. Cheio de desejos e vontades impulsivas. Um homem que se entregou de corpo e alma em tudo que acreditava", destacou-se "nas lutas sociais, políticas e literárias", que o levaram à perseguição pelo czar e degredo na Sibéria.

Revela-se, pela forma de comunicação, que o público-alvo era jovem e deveria sentir-se identificado com a impulsividade, os desejos, as vontades e o idealismo de Dostoiévski. Em 1970, muitos jovens que também seguiram seu ideal e se rebelaram contra o autoritarismo instaurado no país sofreram consequências: ao invés do degredo na Sibéria, a rebeldia Ihes custou a prisão, tortura, morte e exílio. Compreende-se, assim, como a peça procura relacionar os anseios juvenis e a realidade político-social brasileira à biografia do autor, de maneira que estabelecessem vínculos com o público e se eliminasse o distanciamento com um produto cultural de consumo pouco comum à sua camada social. $O$ extenso romance foi vendido da mesma forma que uma história sentimental e de aventura, despertando o interesse em sua leitura. 
Figura 38 - Interior de panfleto de divulgação da coleção Os Imortais da Literatura Universal

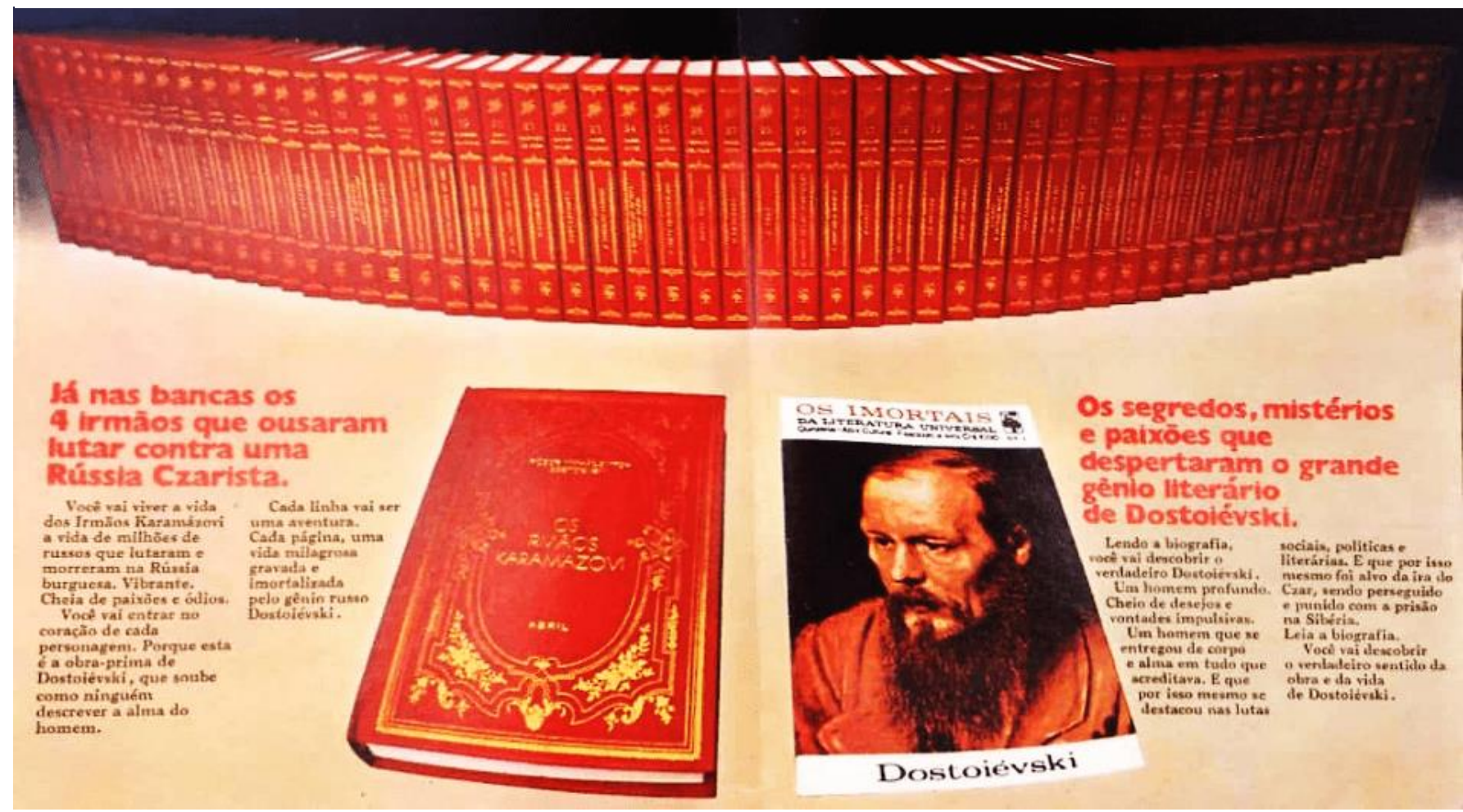

Fonte: DEDOC Abril.

$\mathrm{Na}$ avaliação da peça da figura Figura 39, em conjunto à da figura 40, é possível identificar a mudança no estilo discursivo. O destaque, agora, é para a importância da coleção e seu papel como bem de distinção simbólica. Na figura Figura 39, duas palavras do enunciado representam e descrevem todo o contexto da imagem: "privilégio" e "monumental". A imagem não poderia ser mais clara: a pilha de volumes da Coleção, em grande escala, centralizada e ocupando quase toda a área da página, impõe-se como um monumento ao conhecimento, às artes, à literatura, enfim, ao saber erudito representado pelos livros e seu suntuoso formato. O homem, reduzido, posto a escanteio, torna-se ínfimo perante o poder que emana da cultura bibliográfica. Sua insignificância, porém, é remediada pelo fato de ser ele um "privilegiado", posição esta que o distingue dos demais. A posse da coleção deixa, então, de sobrepujar o distinto senhor para dele tornar-se um suporte, sustentáculo de suas ambições sociais e econômicas. "Monumental" e "privilégio" são duas palavras, como se vê, que valoram a coleção em relação às outras: enquanto uma contrasta com a banalidade dos livros "comuns", a outra cuida de 
exaltar o consumidor rebaixando todos os outros que não têm acesso aos mesmos produtos.

A Figura 40 adota a mesma linha semântica da anterior, já no título da peça definindo uma alcunha à "coleção dos privilegiados" 60 . Segue destacando a extensão do primeiro volume, "626 páginas", e suas qualificações: "[...] luxuosamente encadernado." "Com as capas gravadas em ouro. Finamente acabadas". Nota-se que as pausas impostas pela pontuação ressaltam a descrição. Os fascículos, por sua vez, não ficam atrás e são "ricamente ilustrados". Percebe-se que os advérbios "luxuosamente", "finamente", "ricamente" têm por função enaltecer a coleção, derivando dos adjetivos "luxuoso", "fino", "rico", relacionados às elites e ao alto padrão de vida. Segue-se com a repetição da ideia de que adquirir a coleção é um privilégio e "privilegiado" será quem puder tê-la em "sua estante". Aqui, retorna-se à questão da estante como suporte para símbolos distintivos a serem exibidos nas áreas de acesso comum da residência (principalmente nas salas de estar), de que tratamos no capítulo precedente. Apela-se, em seguida, para o valor dos livros sob o ponto de vista da qualidade dos autores e respectivas obras, o que, junto à indicação do catálogo parcial da coleção, com 32 títulos, funciona como prova de apoio à compra.

$\mathrm{Na}$ figura Figura 41, é possível avançar na interpretação dos elementos formadores do perfil de público para a coleção. A peça demonstra a importância do fascículo biobibliográfico que acompanha cada exemplar como instrumento de mediação à leitura dos textos ficcionais, através da apresentação do panorama político-social em que o autor viveu. Ao mesmo tempo, apela-se para o caráter da distinção, pois, ao serem encadernáveis, os fascículos formavam volumes adicionais, possibilitando a formação de uma coleção à parte, integrada à principal, "[...] tão rica e luxuosa quanto à primeira", com capas gravadas "[...] em ouro".

A imagem posicionada na parte inferior esquerda da página é relevante para que se compreenda parte do contexto brasileiro da década de 1970. É possível

60 A questão do privilégio na sociedade e cultura brasileiras reflete-se no teor dos discursos das peças. Gilberto Freyre, Sérgio Buarque de Hollanda e Roberto da Matta são alguns dos que se dedicaram a tratar o tema. Mais recentemente, o sociólogo Jessé de Souza deu-Ihe destaque em "A tolice da inteligência brasileira", no qual faz uma crítica ao pensamento dos intelectuais brasileiros sobre 0 assunto. 
identificar um homem, aparentemente um pouco mais velho que o presente na figura Figura 39, sentado em uma poltrona em que lê o que parece ser um dos exemplares da coleção61. Ao seu lado, uma mulher, sua esposa, segura nas mãos o fascículo do exemplar. Atrás de ambos, uma criança, filho do casal. Aqui, retoma-se a configuração abordada na análise da propaganda televisiva de Conhecer, em que o homem exerce a função de provedor material e intelectual da família, aquele autorizado a ter acesso ao conhecimento e transmiti-los aos demais membros. À mulher, fora da poltrona, afastada da leitura séria, é oferecido o fascículo, didático, introdutório, colorido e superficial.

Os anos 1970 foram de profundas transformações no país e no mundo e uma delas era a emancipação da mulher do papel subalterno ao homem. Não se pode dizer que a Abril desconhecia este movimento e suas consequências no consumo. Entre as revistas que editava, estava Claudia, no catálogo de periódicos da empresa desde 1961, voltada à "mulher do lar", cujas preocupações principais eram o cuidado com a casa e a alimentação do marido e dos filhos. Procurando atingir um público feminino voltado não mais aos afazeres domésticos, mas concentrado em sua carreira profissional, no mercado de trabalho, sexualidade, participação social, entre outros, lançou a revista Nova (versão brasileira da Cosmopolitan), em $1973^{62}$. A personagem feminina da peça é uma mulher de Claudia, e não de Nova, como se vê, porque a estratégia publicitária era atingir o homem, jovem, com família recémformada.

O consumidor em potencial de uma coleção de livros clássicos não é, de maneira geral, diferente daquele de livros populares, apenas as motivações de compra é que são distintas. A forma como se apresenta o enredo de Os Irmãos Karamázov nas peças publicitárias indica que o leitor de romances de aventuras, velho-oeste e policiais, muito comuns naquele momento e considerados de menor

61 É seguro, pelo volume de páginas, afirmar que seja um livro. Entretanto, a capa parece flexionarse levemente ao ser manipulada, o que seria um indício de que se trata de uma brochura, que não é o padrão de encadernação dos exemplares da coleção. Como a foto do panfleto é de tamanho reduzido e baixa qualidade, não foi possível definir qual seria o volume manipulado pelo homem. Independentemente do formato, o fato de o volume ser um livro não invalida o teor da análise efetuada.

62 A pílula anticoncepcional foi fundamental no processo de emancipação da mulher a partir de 1960, ano em que foi aprovada sua comercialização nos EUA. No Brasil, a venda da pílula iniciou-se em 1962. Pode-se dizer que "Cláudia" era uma revista da mulher pré-pílula, e "Nova", a da mulher pós-pílula. 
qualidade, seria aquele para quem a Abril imaginava vender sua coleção. Quando analisados em conjunto, a apresentação do enredo e o discurso sobre a materialidade, importância e a conspicuidade da obra levam a crer que se trata de um público composto por leitores oriundos de classes mais baixas e habituados a uma outra tradição ficcional, que ascenderam socialmente a partir do amplo crescimento econômico do período e procuravam meios de se estabelecerem e se distinguirem no novo estrato recém-conquistado ao consumir bens de luxo e considerados de "alta cultura", embora ainda estivessem vinculados ao gosto pela estrutura e estética de enredos comuns aos romances populares. 
Figura 39 - Panfletos de divulgação da coleção Os Imortais da Literatura Universal

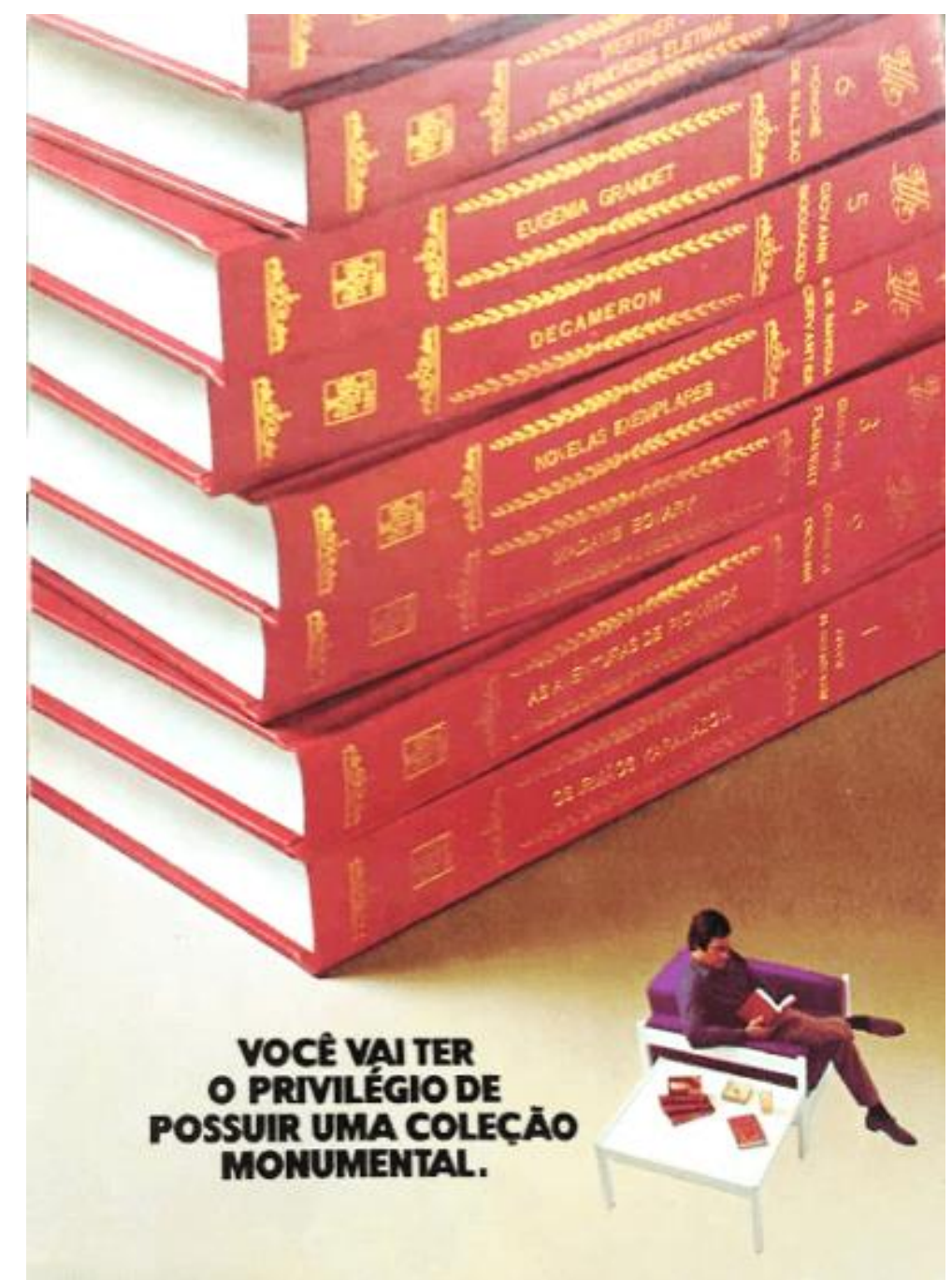

Fonte: DEDOC Abril.
Figura 40 - Propaganda veiculada na Revista Realidade

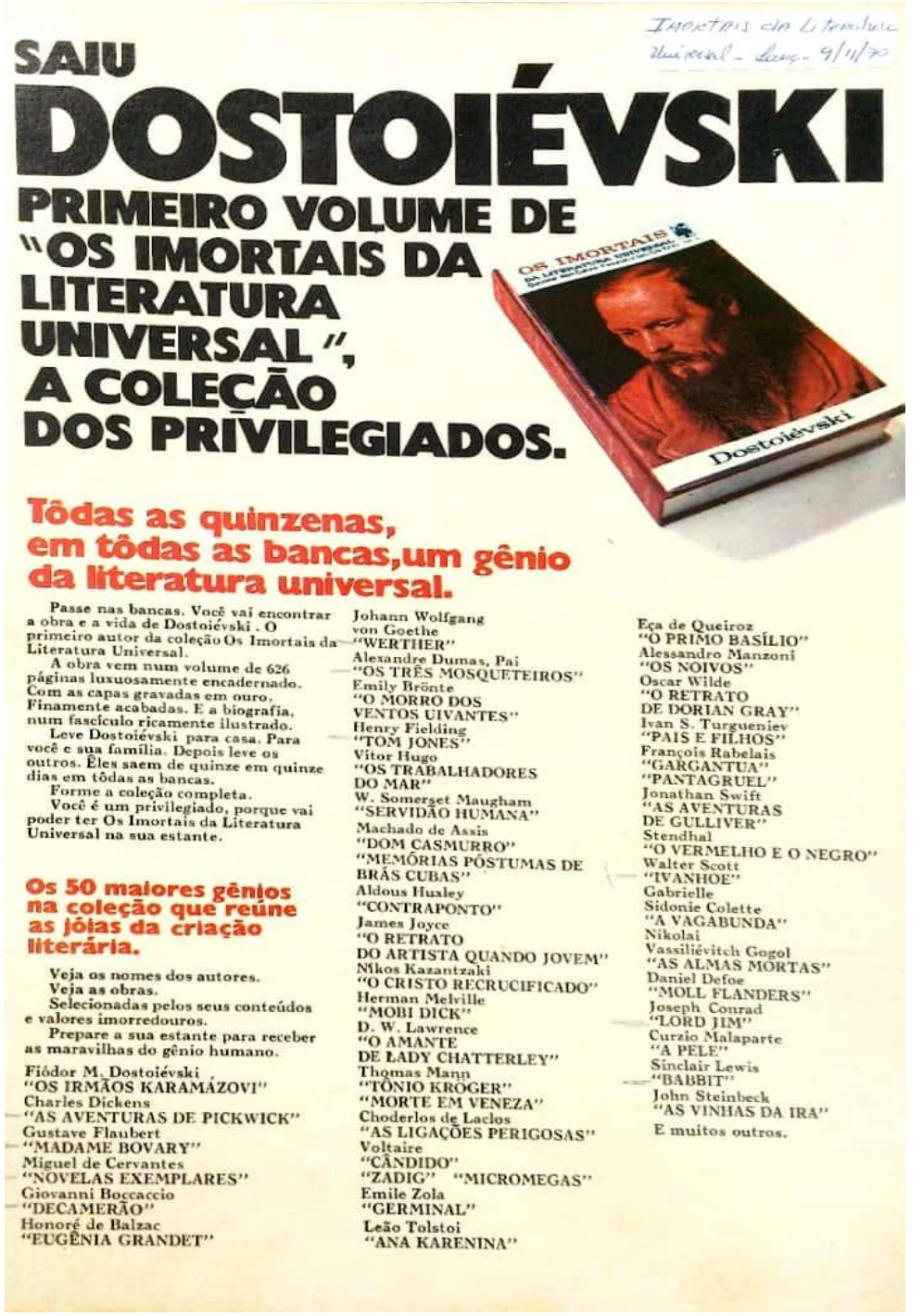

Fonte: DEDOC Abril. 
Figura 41 - Panfleto de divulgação da coleção Os Imortais da Literatura Universal

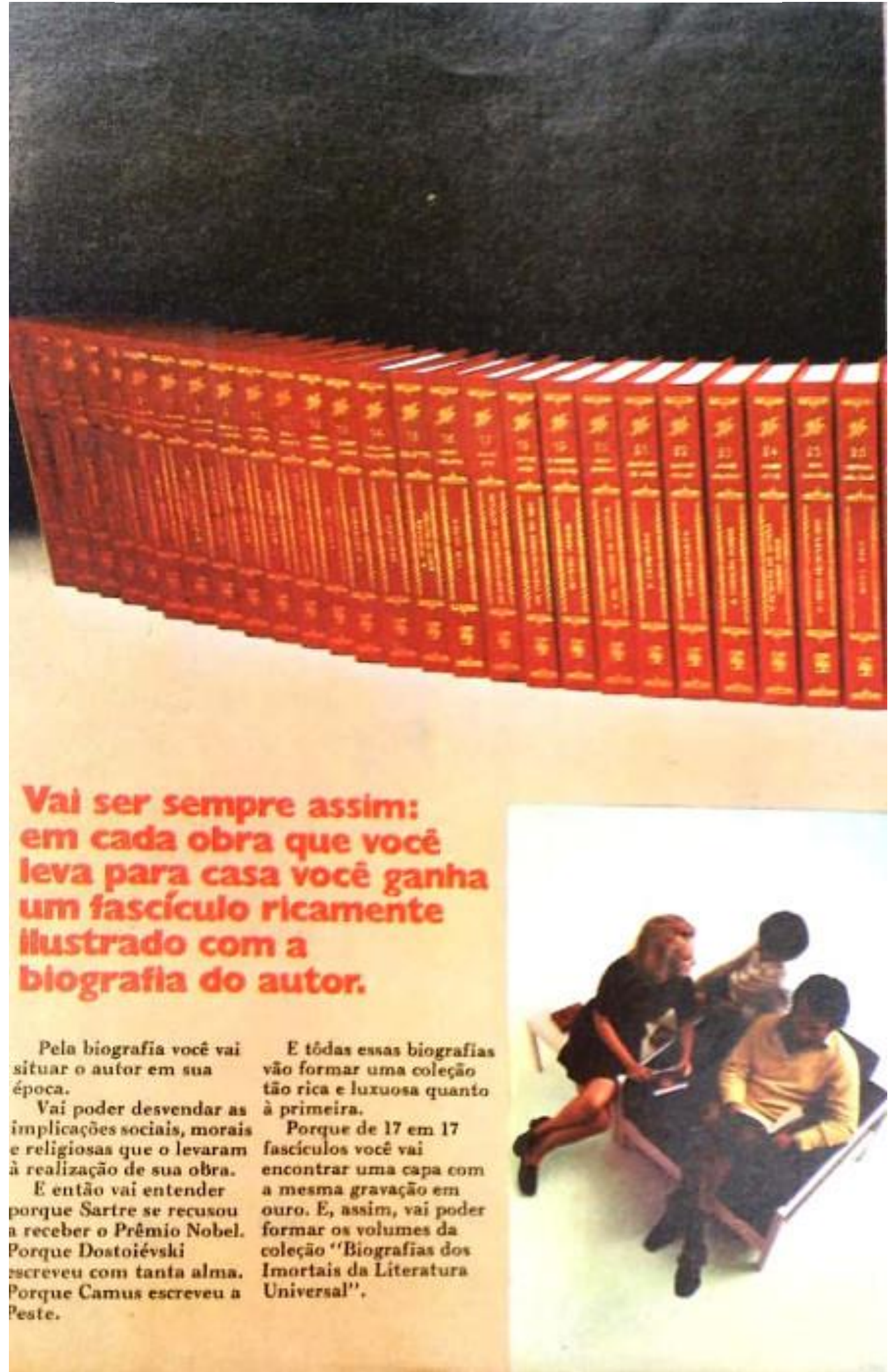

Fonte: DEDOC Abril. 


\subsubsection{Os Pensadores}

A coleção Os Pensadores foi publicada quando a Abril já possuía segurança no mercado de livros completos comercializados em bancas de jornais, devido ao bom volume de vendas de Os Imortais da Literatura Universal. Pedro Paulo Poppovic, em reportagem veiculada na Revista Veja sobre o lançamento da coleção, dá indícios sobre o tipo de discurso que as peças publicitárias adotariam ao revelar que a propaganda procurava convencer o leitor de que as ideias filosóficas não são “ociosas, vazias e distantes" (A GRANDE..., 1972), demonstrando que a filosofia poderia responder a questões práticas do momento e da vida cotidiana, em vez de limitar-se ao plano da especulação. Para Poppovic, os consumidores pretendidos pela Abril eram "os estudantes, de um lado, e, de outro, um público em ascensão social que procura se cercar da segurança de obras de valor" (A GRANDE..., 1972, p. 115).

A imagem observada na figura Figura 42 é a capa de um folder de divulgação de Os Pensadores. Nota-se que a comunhão entre enunciado e imagem foi pensada para causar impacto na audiência e estimular a abertura e leitura da peça. O públicoalvo está representado nessa cena: um jovem, sexo masculino, classe média. Porta um exemplar da coleção à mão, estendendo-o ao senhor, de terno e óculos, logo ao seu lado. Não se consegue estabelecer, ao certo, se ambos leem juntos a obra ou se o jovem estende ao senhor o livro em busca de sua opinião ou aprovação em algum ponto do texto ${ }^{63}$. Mas não há dúvidas de que o idoso simboliza a figura do "intelectual", do "professor", do "especialista" bem-sucedido. A relação triangular entre "jovem (público)", "senhor (intelectual)" e livro é resumida pelo enunciado: "Você é mais respeitado na medida em que sua cultura aumenta". "Você" refere-se ao jovem da imagem, que representa o público-alvo. "Respeitado" relaciona-se com o idoso (alta classe), agente legitimador. E a "cultura" é representada pelo "livro", detentor simbólico do acesso ao conhecimento. Assim, o livro é capaz de inserir o "leigo" (jovem) na "cultura" do "erudito" (senhor), fazendo-os compartilharem o olhar, tornando o jovem respeitável.

63 Pela posição da mão esquerda do "senhor", é provável que a segunda hipótese seja mais plausível. 
Figura 42 - Capa de folder de Os Pensadores

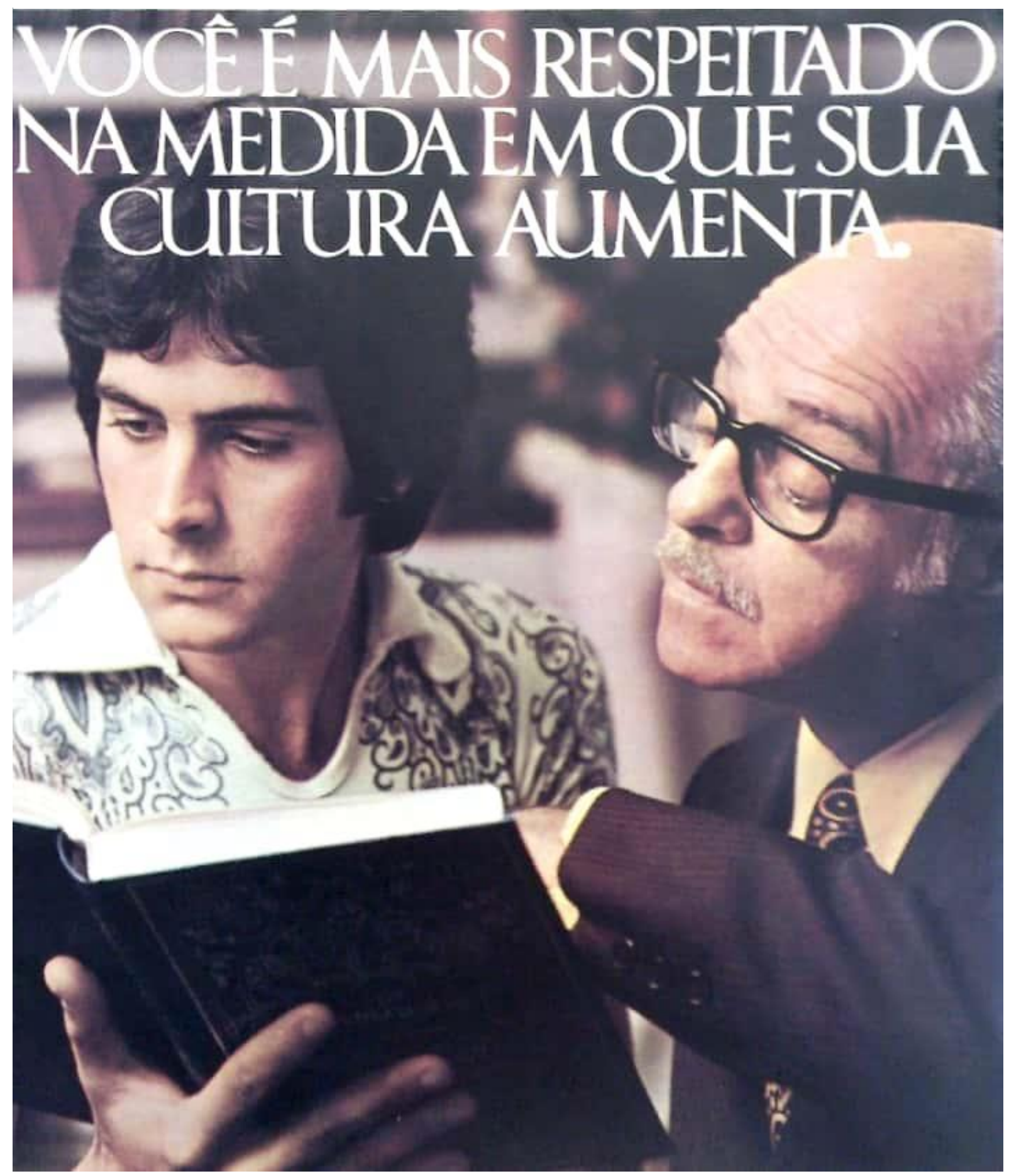

Fonte: DEDOC Abril. 
Figura 43 - Miolo de folder de Os Pensadores

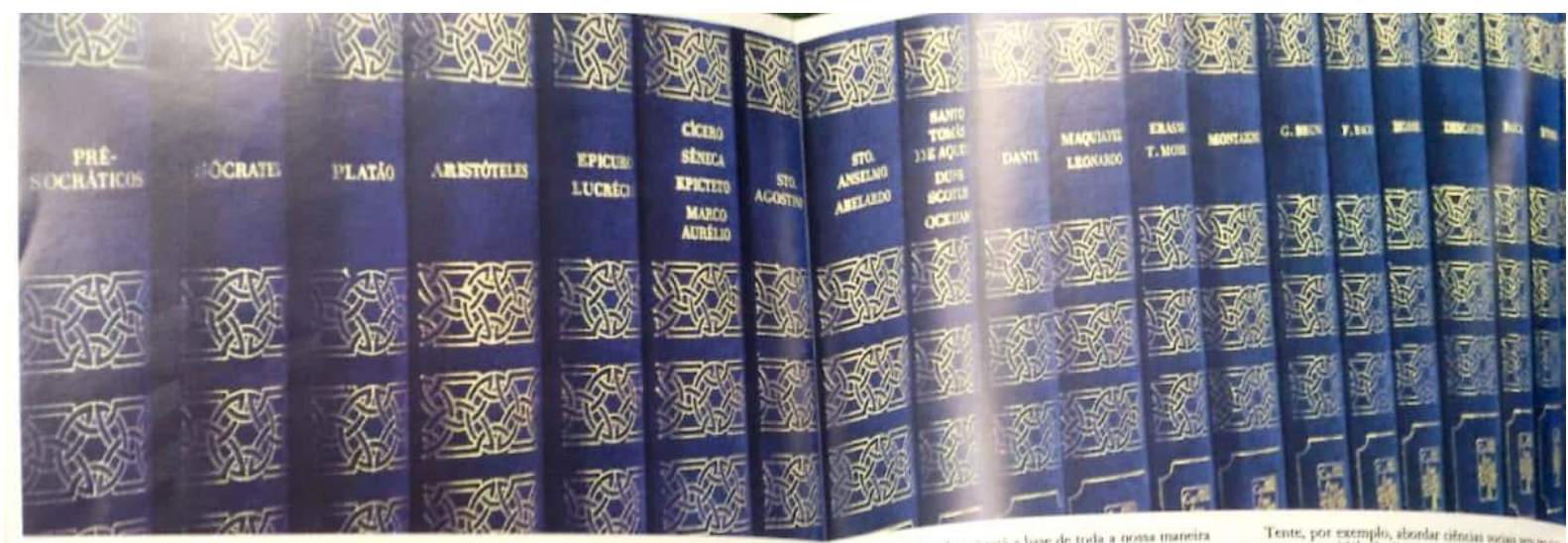

GEMTR A ABRIL CUITUIRALORGULHA-SE DE ADRESENTAR

S羿 UMDOS MAIORES EMIPRENDIMENTOSEDITORIAS

E. DE TODOS OS TEMPOS.
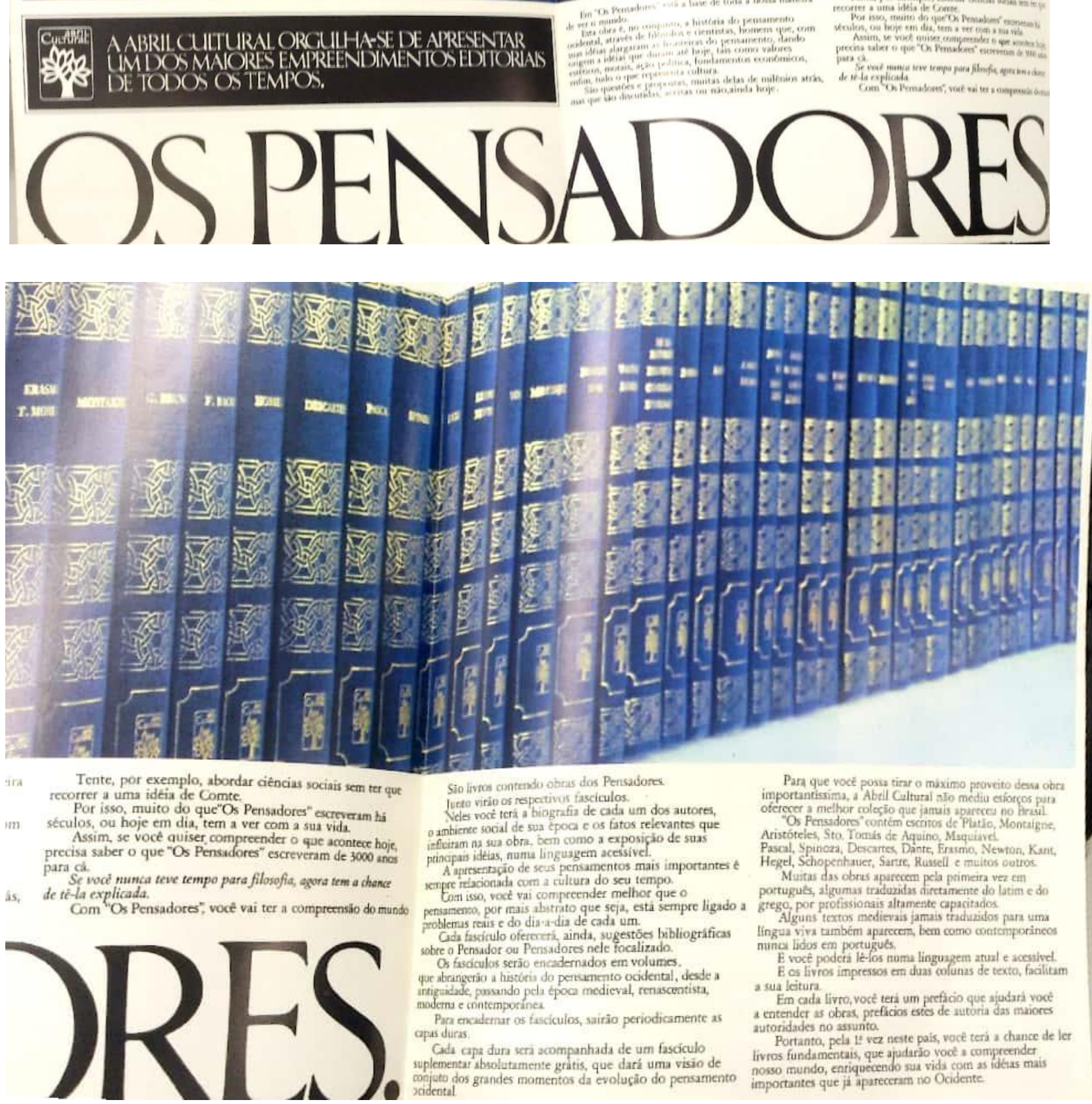

Fonte: DEDOC Abril. 
Ao se abrir o folder (Fig. Figura 43), tem-se, na parte superior, uma fileira de livros formada pela reunião dos volumes da coleção, novamente dando destaque à capa dura com lombada gravada e dourações. No segmento inferior, o título da coleção, com tipos em caixa alta de grande tamanho que acompanham a metade do comprimento dos exemplares na parte superior. Entre os dois elementos, na página esquerda, há um quadro de fundo negro, onde se lê, em letras brancas de bom contraste, o anúncio de que "a Abril Cultural orgulha-se de apresentar um dos maiores empreendimentos culturais de todos os tempos". Aqui, o nome da Editora é utilizado como prova de apoio à compra e a concepção majestosa, imponente, repetindo o tom "monumental" de Os Imortais da Literatura Universal, funciona como elemento valioso para a diferenciação do projeto em relação a outras publicações de filosofia ou humanidades.

$\mathrm{Na}$ sequência, o texto procura ajustar-se aos objetivos propostos por Poppovic, reduzindo a percepção especulativa e pouco pragmática que a filosofia possui perante o senso comum, situando-a como campo essencial para interpretação dos fenômenos do cotidiano e do presente: "os pensadores são a base de nossa maneira de ver o mundo", pois deram origem a "[...] ideias que duram até hoje [...]", "[...] valores estéticos, morais, ação política, fundamentos econômicos, enfim, tudo que representa cultura". "São questões e propostas, muitas delas de milênios atrás, mas que são discutidas, aceitas ou não, ainda hoje". A palavra "hoje" está presente duas vezes nos três primeiros parágrafos, reforçando a utilidade, naquele momento, de ideias que popularmente poderiam estar associadas ao passado, obsoletas e inadequadas. Na sequência, mais um indicativo sobre uma parcela do público, formada por universitários de cursos voltados às ciências humanas: "tente, por exemplo, abordar ciências sociais sem ter que recorrer a uma ideia de Comte". O discurso reitera, nos próximos dois parágrafos, o valor da filosofia para a atualidade e a práxis cotidiana: “[...] muito do que 'Os Pensadores' escreveram há séculos, ou hoje em dia, tem a ver com sua vida" e "[...] para compreender o que acontece hoje [...]" é necessário voltar ao que Os Pensadores "[...] escreveram de 3000 anos para cá".

Após deixar claro ao leitor que a filosofia é "útil" e "atual", o texto procura romper outra possível resistência do público: o pensamento filosófico como algo hermético. $\mathrm{O}$ instrumento mediador, claro, é o fascículo, que "explicará" a filosofia, 
através da "biografia de cada um dos autores, o ambiente social de sua época e os fatos relevantes que influíram na sua obra, bem como a exposição de suas principais ideias, numa linguagem acessível". Os principais pensamentos dos filósofos são relacionados "[...] com a cultura de seu tempo", para que se compreenda que "[...] por mais abstrato que seja[m], está[ão] sempre ligado[s] a problemas reais e do diaa-dia de cada um [dos leitores]". Novamente, observa-se a presença do pragmatismo como justificativa para a compra e a presença de "[...] sugestões bibliográficas [...]" reforça a ideia de um público universitário, com maior grau de instrução formal.

Algumas características exclusivas da coleção acentuam a noção de "privilégio", ainda que, diferentemente de Os Imortais da Literatura Universal, não esteja presente o termo: “[...] a melhor coleção que jamais apareceu no Brasil”, com obras editadas "[...] pela primeira vez em português, algumas traduzidas diretamente do latim e do grego [...]", incluindo "[...] textos medievais jamais traduzidos para uma língua viva, bem como contemporâneos nunca lidos em português". Já entre os benefícios da coleção, estão a "[...] impressão em duas colunas de texto [...]", para facilitar a leitura, algo que não foi implementado em todos os volumes, como vimos, e prefácios escritos pelas "maiores autoridades no assunto" para auxiliar o leitor a "[...] entender as obras [...]".

A parte de trás do folder concentra-se em destacar, novamente, a relação do pensamento filosófico com a vida prática da atualidade, através de exemplos como Platão e o significado da arte; Comte e Max Weber e o comportamento social do homem; John Locke e a Constituição americana; Santo Agostinho e a teologia moderna; Bacon e o método indutivo, raiz da sistematização do método científico; entre outros. Também reestabelece o discurso do privilégio: "Mesmo que as pessoas nasçam iguais, quanto mais o tempo passa, mais desiguais ficam. Umas ficam mais cultas, outras menos". A solução para essa "desigualdade" é o acesso à cultura, representado pela Coleção.

A peça, ao ser fechada64 (Fig. Figura 44), designa, definitivamente, a coleção como elemento cultural que se traduz em pertencimento. A frase "uma coleção que 
não pode faltar em uma casa onde a cultura é respeitada" atua como elemento persuasivo ao conduzir o público à crença de que, caso não possua a coleção, a cultura não é respeitada em sua casa - o que, obviamente, não é verdadeiro. $A$ casa, como espaço privado de convívio da família, sendo um lugar onde "se respeita a cultura"65, terá, por certo, pessoas que "gostam de ser mais inteligentes, cultas e atualizadas", contanto que em suas estantes esteja a coleção Os Pensadores. Reconhecer na coleção a reunião de best-sellers que "nunca sairão da lista" é mais um apelo ao leitor da classe média ascendente, íntimo, provavelmente, dos mais vendidos, mas estranho aos símbolos da "alta cultura" clássica.

Figura 44 - Fragmento do verso do folder
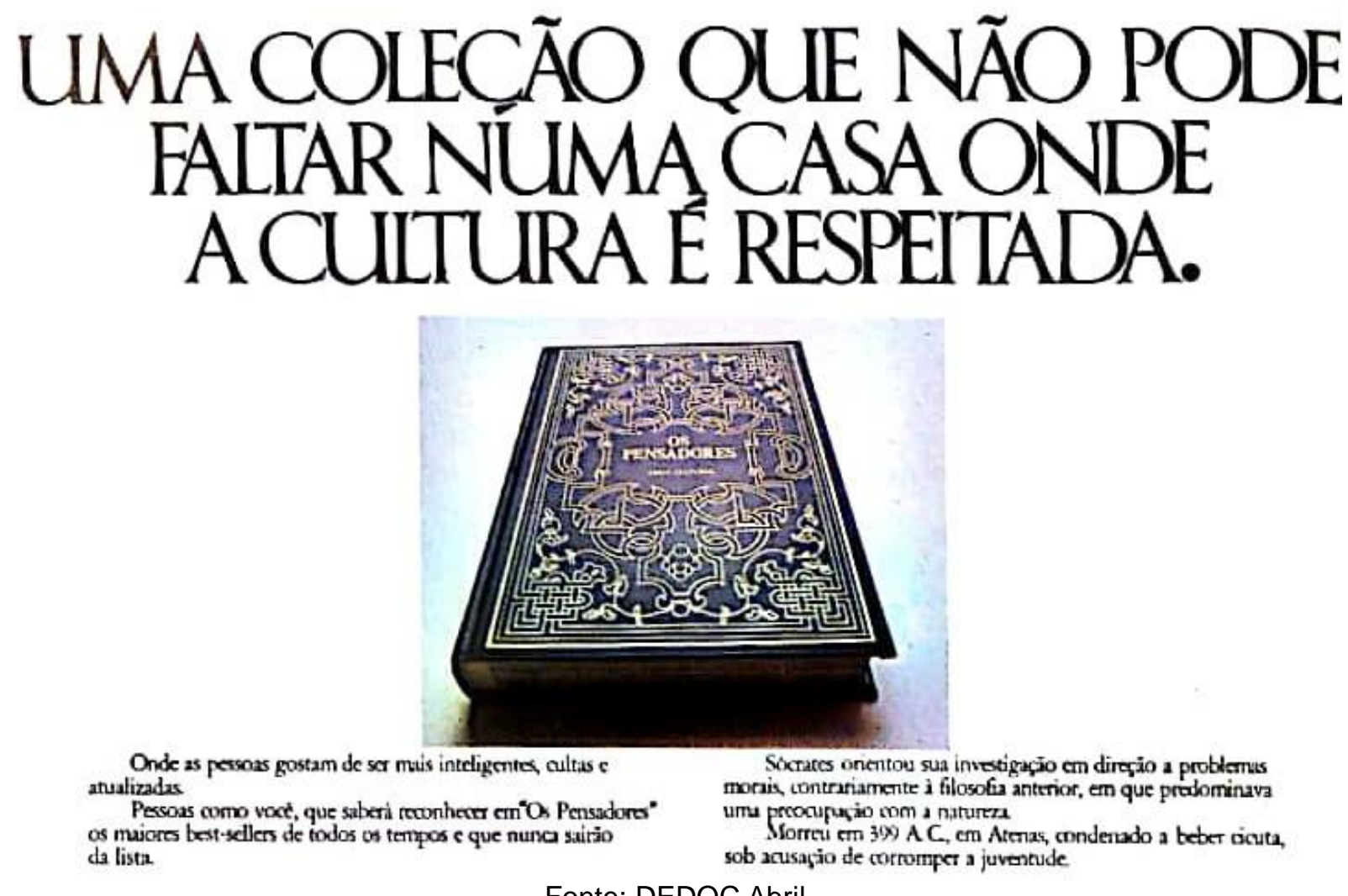

Fonte: DEDOC Abril.

Por fim, é importante registrar que em nenhuma das propagandas consultadas há destaque ao volume "luxuosamente encadernado", "com capas gravadas a ouro", "finamente acabadas". Ao contrário de Os Imortais da Literatura Universal, o luxo material da encadernação dos volumes não é utilizado como

65 Aponte-se a arbitrariedade do termo "respeito", como condição para a relação com a "cultura". 
recurso persuasivo, provavelmente pelo entendimento, por parte da Editora, de que o público-alvo da coleção teria real interesse na leitura dos exemplares e a valorizasse mais como instrumento cultural que, ao ser apreendido, levaria à distinção, além da simples posse e exibição dos volumes. A ênfase na acessibilidade da filosofia através dos elementos paratextuais e na sua função prática corrobora esta perspectiva.

\subsubsection{Teatro Vivo}

Lançado em 1976, Teatro Vivo foi a última grande obra, no que tange a uma coleção de livros completos, editada pela Abril Cultural nos anos 1970. A crise do país e a concorrência com outras editoras no mesmo segmento, no entanto, não fez com que a Abril se tornasse mais parcimoniosa em suas ações de marketing. Conforme destacamos, o projeto e patrocínio da peça $O$ Gesto, A Festa, $A$ Mensagem: 2000 Anos de Teatro, idealizada pela agência Gang, mostrou que a Editora ainda se mantinha à frente das demais no que diz respeito à utilização de sua máquina publicitária. Não apenas a divulgação, mas o discurso parece não ter sentido os efeitos da crise econômica: com formato menor dos volumes e "fascículos" inclusos nos próprios exemplares, a coleção, mais compacta, não deixou de lado as hipérboles também presenciadas na promoção de Os Imortais da Literatura Universal e Os Pensadores.

As estratégias adotadas no discurso publicitário de Teatro Vivo eram, em certos aspectos, semelhantes às de Os Imortais [...]. Havia a necessidade de se atingir a um público-alvo que não era iniciado na leitura de peças teatrais, embora frequentasse o teatro para assisti-las. Os anúncios foram produzidos, dessa forma, utilizando expressões familiares ao meio teatral para aproximarem seu público das peças escritas. No panfleto (Fig. Figura 45) que acompanhou Hamlet, o primeiro livro da série, expressões como "bem-vindo", utilizada para recepcionar a plateia, e "não perca a continuação deste espetáculo" procuram despertar o desejo pela manutenção da compra dos exemplares da coleção, maior desafio dos editores. A valoração da coleção, "[...] tão importante quanto as mais importantes peças teatrais [...]" é um reforço ao estímulo de se seguir a série. 
O folder (Fig. Figura 46) que acompanhou a proposta de venda dos 10 primeiros volumes da coleção, oferecidos pelo canal de marketing direto, retoma alguns elementos já observados nas análises anteriores. Aqui, tem-se, mais uma vez, como em "Os Imortais [...]", o destaque para a materialidade dos exemplares, "[...] em rica encadernação, gravados a ouro!"; mas, diferentemente da coleção de clássicos da literatura, aborda-se a questão da qualidade das traduções, produzidas "com absoluta fidelidade", aspecto também tratado nas campanhas de Os Pensadores. Introduz-se, além disso, um atributo até então não registrado, a raridade. Ao assinalar a coleção como "o início de uma biblioteca de livros raros", é adotada uma estratégia retórica que remete, novamente, ao conceito de privilégio: claro está que não se trata de livros raros, devido à alta tiragem das obras, mas de produtos de acesso restrito, não inseridos anteriormente sequer no circuito convencional das edições para livrarias. Neste ponto, a ideia de "álibi" proposta por Baudrillard parece adequada: mesmo que soubessem que os livros não eram "raros", já que todos com condições de pagá-lo poderiam possui-los, o consumidor valia-se da propaganda como álibi para sua necessidade, refletida na compra da coleção, de fazer sentido à existência e diferenciar-se socialmente.

Figura 45 - Panfleto de incentivo à manutenção da coleção

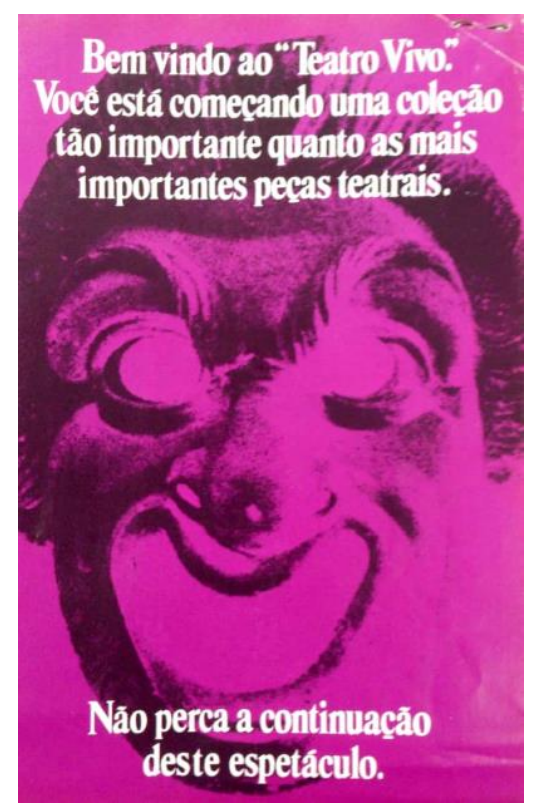

Fonte: DEDOC Abril. 
Figura 46 - Folder para promoção da venda por marketing direto

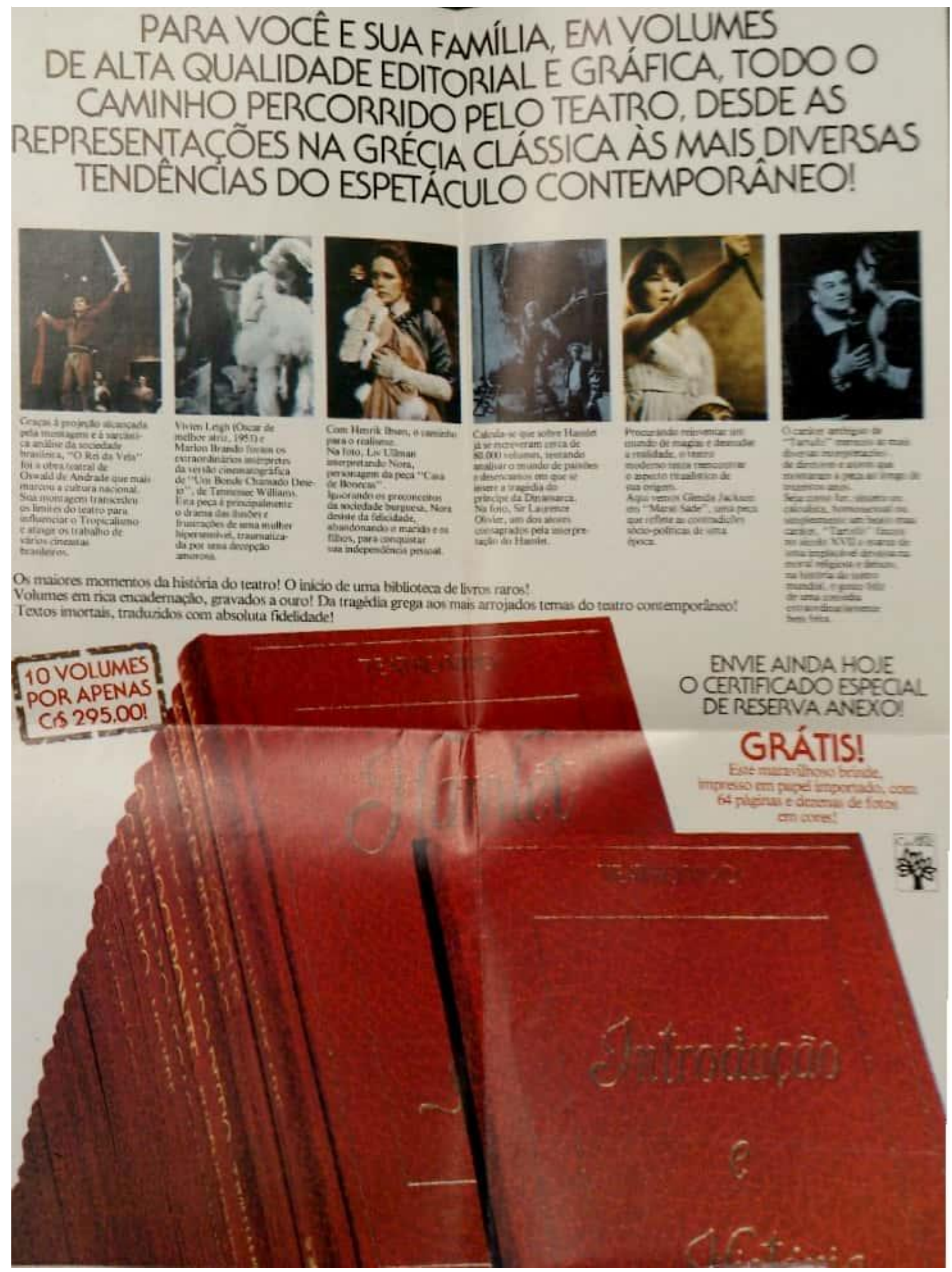

Fonte: DEDOC Abril. 
A revista Veja trouxe em sua edição número 399, que circulou dia 28 de abril de 1976, uma peça de divulgação de Teatro Vivo que ocupou duas de suas páginas (Fig. Figura 47). Apresentando imagens de cenas teatrais em pequenos quadros, bem como a reunião de um grande "elenco de autores" à direita e os volumes incompletos da coleção na parte inferior, esta propaganda retoma, assim como a anterior, aspectos do discurso de Os Imortais da Literatura Universal e Os Pensadores. Logo no início, o público é informado sobre a influência dos "[...] conflitos sentimentais, morais, políticos e sociais [...]" sobre os autores da coleção, um discurso muito semelhante aos das "[...] implicações sociais, morais e religiosas [...]" que levaram escritores de "Os Imortais [...]" a produzirem seus textos. O apelo ao enredo sentimental tradicional dos romances populares é perceptível no trecho “'Teatro Vivo"” irá emocionar você, provocando raiva, vontade de chorar ou rir, sentimento de pena, solidariedade [...]", assim como a passagem "[...] ajudará você a compreender suas próprias reações diante da obra do teatro e da vida" introduz, no texto teatral, um sentido prático, aplicável à vida cotidiana, como fez o discurso de Os Pensadores com a filosofia. Da mesma forma, o "monumental" de "Os Imortais [...]" é substituído por "[...] um dos mais importantes documentos de cultura para o conhecimento e interpretação dos períodos da história da humanidade [...]", enquanto "[...] um dos maiores empreendimentos culturais de todos os tempos" segue a estratégia de Os Pensadores.

A redução no formato demandou o esforço extra dos publicitários para explicar ao público o motivo de os volumes não terem tanta pompa quanto o das outras coleções. Por se tratarem de textos teatrais, o menor formato é mais prático, pois os livros "[...] permitem uma leitura cômoda, são fáceis de manusear, e se encaixam perfeitamente no espaço normal de uma estante". Como os móveis da "Mobília Contemporânea" produzidos para armazenar as coleções de fascículos já não eram mais comercializados, o consumidor utilizar o espaço disponível nos seus móveis já não seria um problema para a Abril. Em cada um dos volumes, agora encadernados, os "fascículos" permanecem como instrumento de mediação para acesso ao texto teatral, pois neles encontrará, o leitor, "[...] a biografia do autor, apreciações críticas, históricas, e uma grande quantidade de ilustrações mostrando pessoas, fatos e locais relacionados com a vida e obra do autor, as principais cenas das montagens nacionais e internacionais". 
Figura 47 - Peça promocional de Teatro Vivo em duas páginas de Veja

\section{"TeatroV}

Abril Cultural apresenta uma

olesăo taio importante quanto as
nais importantes pesas teatrais.

Uma obra sobre os conflitos senti-
nentais, morais, politicose sociais, vi-

idos descle os termpos dos gregos ate
loje, na interpretaça de seus mais

ofocles, Moliere, Brecht, Prindello

kett, lonesco, Tennewsee Williams
dososoutros autores que marcaran

poca.
Em cada volume de "Teatro Vivo",
oć́ encontrará aleme do texto com.

octe encontraras alem do texto con.
leto das pecas, a biografia do autor.

preccicuos criticas, historicas, eum
rande quantidade de ilustraçóe

as principais cenas das montagens

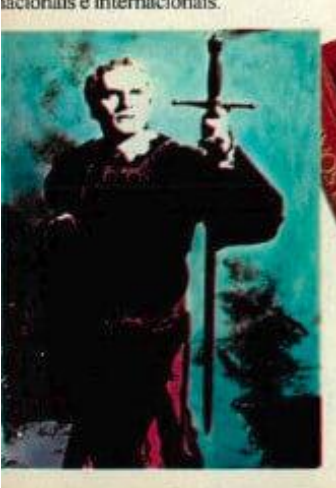

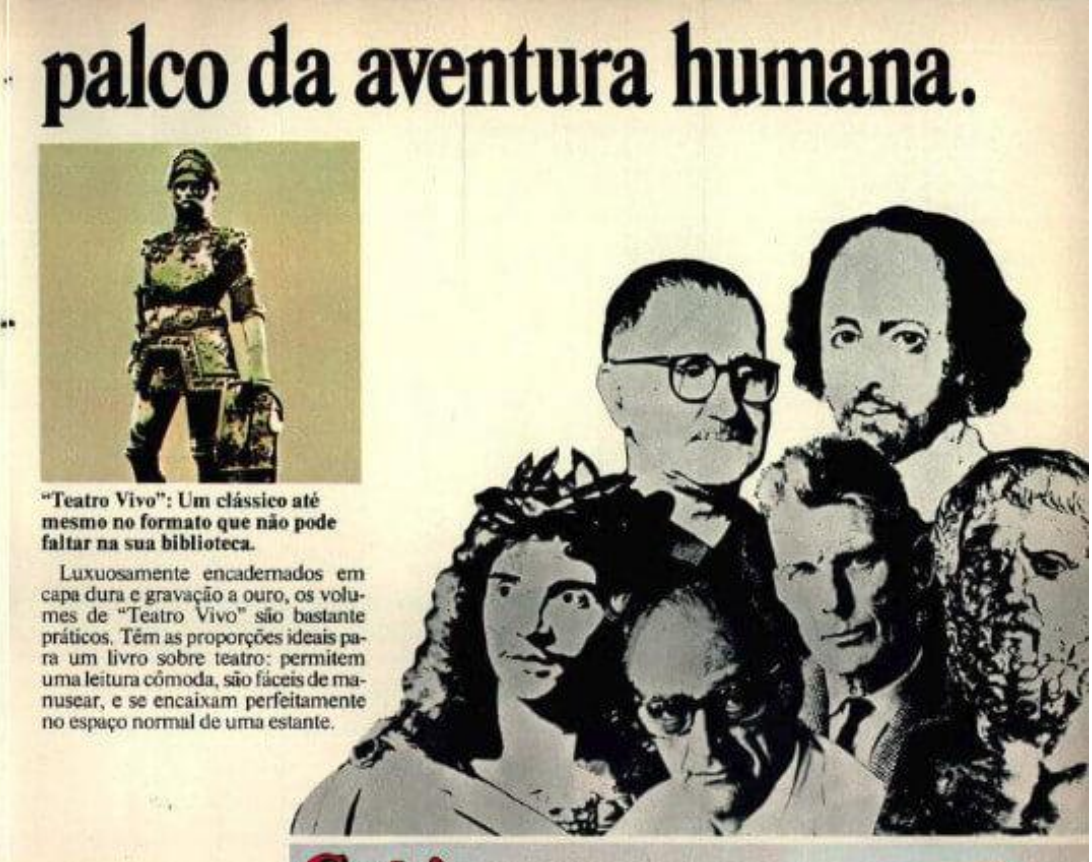

\section{Grentis}

Um livro sobre a historia do teatro.

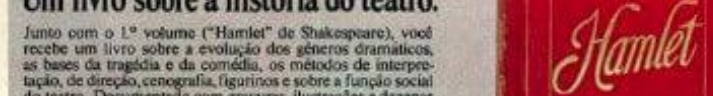

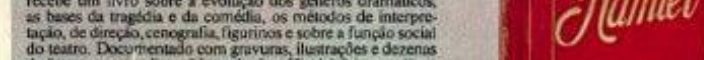
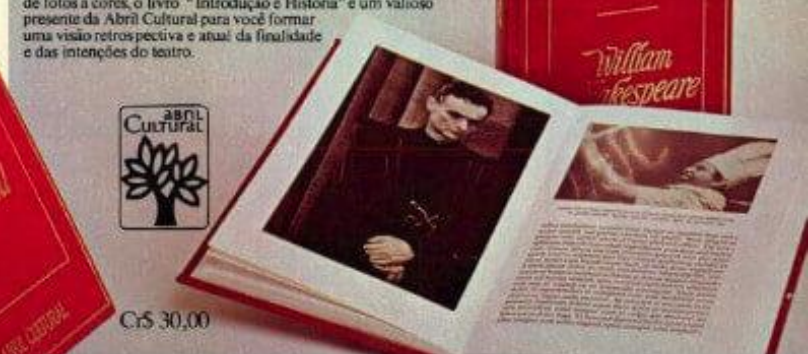

Fonte: DEDOC Abril. 
Interessante notar que, apesar de se tratarem de propagandas de textos teatrais, as peças não apresentam "cenas" fotografadas com modelos, como ocorreu nas coleções anteriormente avaliadas, com quem o público pudesse se identificar de maneira mais direta. Do mesmo modo, em nenhuma das campanhas de coleções da Abril a que tivemos acesso foram retratadas pessoas negras, provavelmente devido à preponderância de brancos nas classes médias, o público-alvo. A mulher também não tem papel de destaque no discurso das coleções de livros, como vimos: está em posição acessória em Os Imortais da Literatura Universal e sequer é retratada em Os Pensadores. O público dos livros colecionáveis vendidos em bancas não foi, portanto, preponderantemente feminino. Em compensação, em fascículos de enciclopédias como Nossas Crianças (Fig. Figura 48), a mulher teve papel de destaque: com o filho ainda bebê no colo, o fascículo em outra mão, a moça ou senhora que examinasse a peça de Nossas Crianças e as comparasse às de Os Imortais [...], que seriam veiculadas dois meses depois, saberia que sua função, conforme as imagens, limitava-se a cuidar dos filhos, tarefa, aliás, que em nenhum momento do texto é atribuída também ao homem, reforçando estereótipos relacionados ao papel do homem e da mulher na sociedade. Publicadas em 1970, essas ações de marketing reproduziam a organização social do período ao terem em vista o consumidor em potencial para cada uma das coleções.

Figura 48 - Propaganda da coleção de fascículos Nossas Crianças

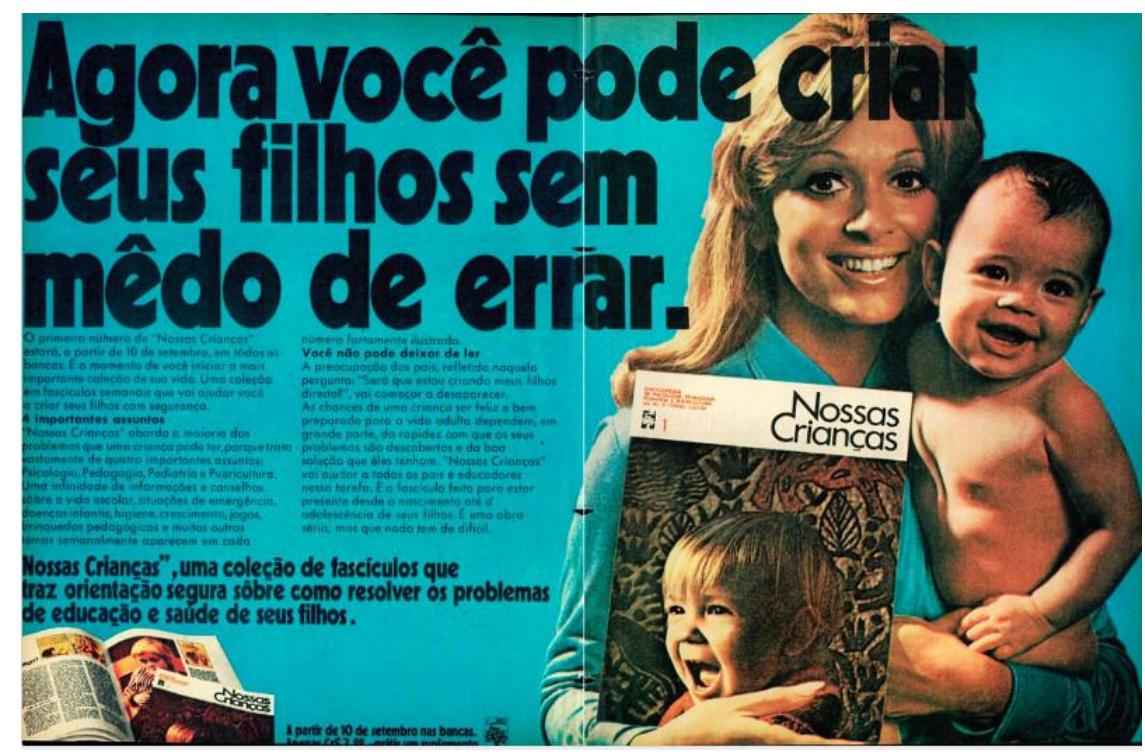

Fonte: Revista Veja no.105. Disponível em: <acervo.veja.abril.com.br>. Acesso em: 27 out. 2017. 
Além das peças voltadas ao consumidor final, existiam outros tipos de ações de marketing que convém abordarmos. A primeira delas é dedicada ao intermediário no processo de venda dos livros em bancas de jornais, o jornaleiro. Seu papel e valor para o processo distributivo das edições será melhor abordado no próximo capítulo; então, nos deteremos aqui, exclusivamente, sobre as questões discursivas da promoção que os envolvia.

Ao se observar a figura Figura 49, um folder distribuído pela Editora aos jornaleiros, constata-se a remodelação da linguagem em relação às peças avaliadas anteriormente. Agora, distancia-se do jogo retórico que procura atender às necessidades objetivas ou subjetivas do público para concentrar-se no pragmatismo das questões financeiras e de estratégias de venda. Há apenas um parágrafo explicando a temática, pois boa parte dos consumidores que a procurava nas bancas já teria contato prévio com alguma das formas de promoção da Abril, e, mesmo assim, seu texto é voltado mais à economia que o comprador teria ao formar a coleção em "[...] apenas 42 fascículos" do que ao conteúdo da obra. 

jornaleiros

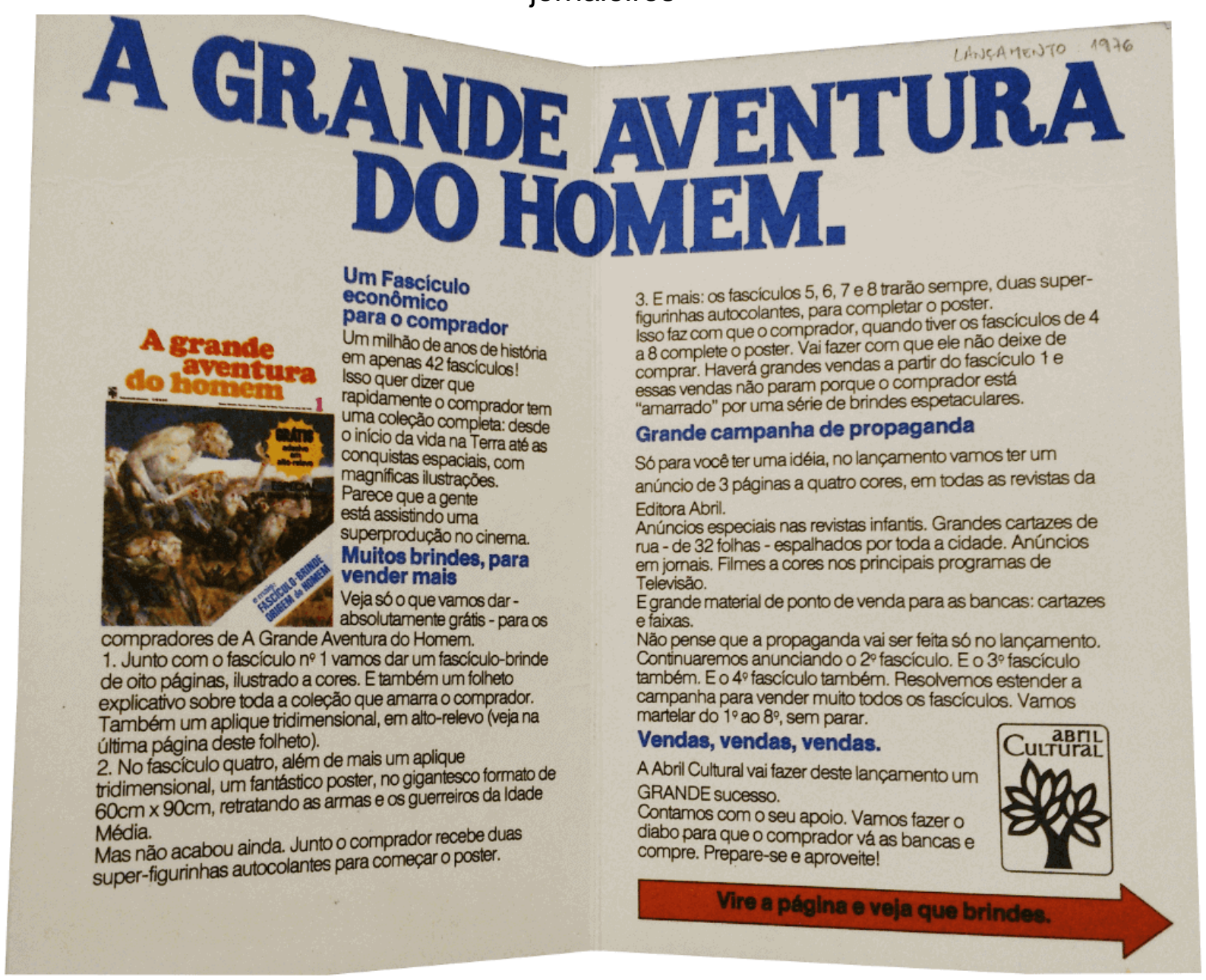

Fonte: DEDOC Abril.

O principal objetivo da campanha é convencer o jornaleiro de que a coleção de fascículos $A$ Grande Aventura do Homem é um produto com alto potencial de venda (e, consequentemente, ganhos para o comerciante). No segundo parágrafo, são destacadas as "vantagens" que o comprador obtém ao adquirir o produto, vantagens que se deve informar ao cliente como forma de convencê-lo. O pleonasmo em "[...] absolutamente grátis [...]" é utilizado conscientemente para reforçar o benefício em se iniciar (e seguir) a coleção. O fascículo extra, entregue como presente junto ao primeiro volume, é acompanhado de "[...] um folheto explicativo sobre toda a coleção que amarra o comprador", aos moldes do que foi apresentado em Os Pensadores. Aqui, a Editora é franca e objetiva ao afirmar seu esforço em manter o público fiel à coleção até o último número, através de estratégias que pudemos acompanhar nas campanhas avaliadas. Entre os brindes 
oferecidos aos clientes, um pôster em grande formato $(60 \mathrm{~cm}$ por $90 \mathrm{~cm}$ ), com duas figurinhas autocolantes, é ofertado junto ao quarto número da série e, para completá-lo, deve-se adquirir os fascículos cinco, seis, sete e oito, que trarão as estampas restantes. E, novamente, a propaganda insiste que o comprador ficará "amarrado", desta vez "[...] por uma série de brindes espetaculares [...]", condição para que haja "[...] grandes vendas a partir do fascículo 1 [...]", garantindo receitas constantes sem o risco de encalhe após o lançamento.

A seguir, a informação de que a coleção será divulgada em "[...] anúncio de 3 páginas a quatro cores, em todas as revistas da Editora Abril" é uma demonstração de uso do poder comunicativo da própria Editora em favor da divulgação das coleções. A segmentação de um mesmo produto para diferentes públicos se revela nos "anúncios especiais nas revistas infantis" e a onipresente máquina de propaganda é representada pelos "grandes cartazes de rua [outdoors] - de 32 folhas - espalhados por toda a cidade. Anúncios em jornais. Filmes a cores nos principais programas de Televisão", além de "[...] grande material de ponto de venda para as bancas: cartazes e faixas". Ao possível receio de que o esforço de divulgação fosse apenas dedicado ao lançamento, o jornaleiro é informado da "insistência" do marketing em anunciar o "[...] $2^{\circ}$ fascículo. E o $3^{\circ}$ fascículo também. E o $4^{\circ}$ fascículo também", até o oitavo fascículo, martelando "[...] do $1^{\circ}$ ao $8^{\circ}$ sem parar". A construção das frases, curtas, pontuadas, indicando pausas, com a repetição do advérbio "também", dá ênfase à "insistência" e remete ao "martelo" comunicativo a que estaria exposto o consumidor. O resultado são "vendas, vendas, vendas", já que a "Abril Cultural" faz "o diabo para que o comprador vá as [sic] bancas e compre", possibilitando bons ganhos ao revendedor.

A propaganda ofertada aos jornaleiros expõe o caráter mercantil da Editora, sob a ótica estritamente comercial. A Abril é uma empresa, mesmo inserida em um contexto cultural, que precisa, como as outras, auferir lucros e elevar sua participação no mercado em cenário competitivo. Mas não tardaram a aparecer críticas de que, por trás do discurso "iluminista" de educação das massas e de culto ao livro como produto cultural, o objetivo fosse estritamente econômico. As críticas despertaram a reação da Editora, que aproveitou a comemoração de seus 25 anos 
de atividade $^{66}$ para veicular em suas revistas uma peça (Fig. Figura 50) onde procurou reposicionar a sua marca ao valorizar suas realizações, coragem e Figura 50 - Propaganda comemorativa "Abril 25 anos"

ousadia.
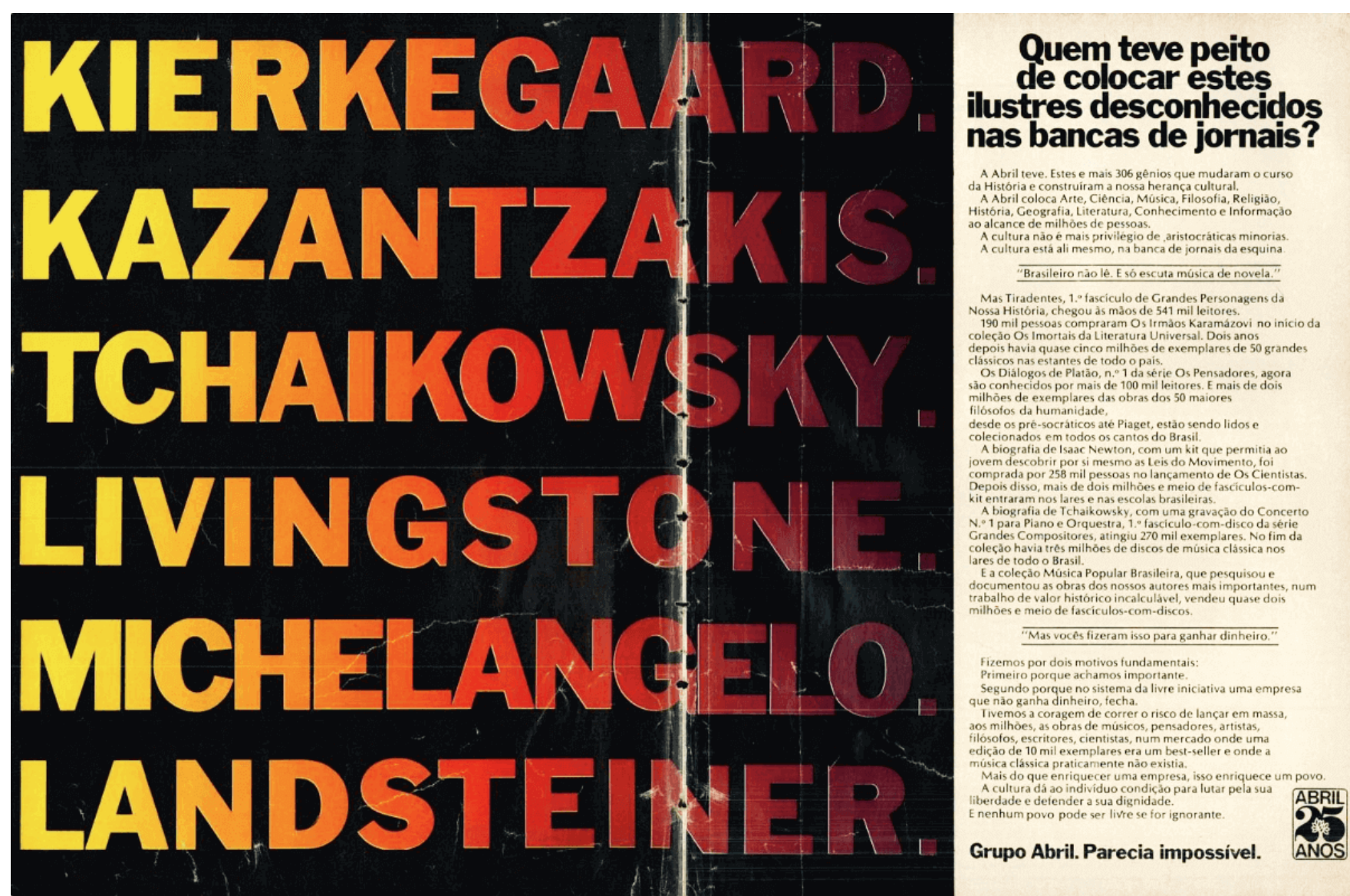

Fonte: Revista Veja, n. 339, p. 44-45. Disponível em: <https://acervo.veja.abril.com.br>. Acesso em: 27 out. 2017.

O discurso começa por defender a coragem da Abril ao investir em produtos culturais, vendidos "[...] na banca de jornais da esquina", num país onde a cultura era "[...] privilégio de aristocráticas minorias", pontuando a relação que afirmamos durante este capítulo entre cultura erudita e alta classe social. A partir da noção comum de que "brasileiro não lê" e "só escuta música de novela", segue informando uma série de dados sobre a vendagem de diversas coleções, que, por si, justificam,

$66 \mathrm{Na}$ verdade, em 1975 a Editora Abril contava com 28 anos de idade, uma vez que foi fundada em 1947, embora, na história veiculada pela empresa, a fundação seja sempre associada ao momento em que Victor Civita inicia as publicações à frente da Editora. 
na visão da Editora, a importância de ter realizado os projetos. Atinge, por fim, o ponto central da campanha, que foi rebater as críticas de que "[...] vocês só fizeram isso para ganhar dinheiro". A resposta sobre o porquê de ter editado as coleções parte de dois motivos, julgados "fundamentais": o primeiro, vago, é de ter achado "importante"; o segundo, sincero, "porque no sistema da livre iniciativa uma empresa que não ganha dinheiro, fecha". Nota-se que a ordenação dos apontamentos estabelece todo o sentido da peça, que é de defender as realizações como algo acima dos princípios econômicos, mesmo que sejam "fundamentais".

Segue-se informando do "risco" que a Editora correu ao introduzir no circuito de massas as "[...] obras de músicos, pensadores, artistas, filósofos, escritores, cientistas", a partir de uma realidade restritiva onde "[...] a edição de 10 mil exemplares era um best-seller e a música clássica praticamente não existia”. Chegase, então, à conclusão de que, pelos empreendimentos e respectivo sucesso, "[...] mais do que enriquecer uma empresa, isso enriquece um povo", pois "[...] a cultura dá aos indivíduos condição de lutar pela sua liberdade e defender sua dignidade", combatendo a "ignorância" que os impede de sua libertação. A estratégia retórica parece reverter de maneira satisfatória a acusação de mero comércio que os críticos imputavam à Editora, ao mesmo tempo em que procura convencer o público da importância civilizadora da Abril para o povo ignorante do Brasil. A tentativa de vender sua marca converte-se, portanto, em um reforço dos estereótipos do brasileiro (e sua cultura popular) como primitivos e dos editores e cultura estrangeiros como civilizadores.

Embora o discurso tenha um caráter ideológico, é preciso ressaltar que, do ponto de vista de sua profissionalização, é fundamental a noção de que uma editora é uma empresa, sem que isso tenha que restringi-la à mera condição de publicadora de impressos de rápido consumo. Os livros, conforme aponta Dessauer (1979, p. 29) "são veículos de ideias, instrumentos de educação e recipientes de literatura. Mas a tarefa de dar-lhes existência e fornecê-los a seus leitores é um trabalho comercial que requer todos os recursos e habilidades do administrador e do empresário". Sob este aspecto, a Abril foi muito bem-sucedida em demonstrar que era, sim, possível comercializar edições de qualidade ao grande público, através do uso correto de 
ferramentas de marketing e distribuição em pontos alternativos, algo antes visto como inadequados para a "sacralidade" do livro.

A análise de algumas peças publicitárias veiculadas para o lançamento das coleções nos permite constatar que a Editora se utilizou das modernas técnicas de propaganda e pesquisa de público para segmentar e estabelecer um perfil preferencial de consumidor para o qual elaborava seu discurso e de quem soube despertar o interesse para viabilizar suas coleções. Através das avaliações, pudemos inferir que a expectativa de consumidor para os "Imortais da Literatura Universal" era contemplada por jovens, do sexo masculino, pertencentes à classe média em ascensão, interessados em literatura clássica mas leitores habituais de romances populares. Já o público de Os Pensadores era masculino, possivelmente universitário ou de uma classe média já introduzida a produtos culturais eruditos, que se interessava por filosofia, mas a considerava um campo hermético, especulativo, que trata de questões antigas que não dizem respeito aos problemas cotidianos. O leitor interessado em Teatro Vivo era mais próximo àquele de "Os Imortais [...]" do que daquele de Os Pensadores, apesar de o discurso se utilizar de alguns elementos comuns à coleção de filosofia da Abril. Era jovem, de classe média ascendente, leitor habitual de livros populares, mas interessado em artes e cultura, como forma de distinção perante os membros de seu grupo social, buscando nas artes respostas para questões que Ihes afligiam.

Como a apropriação dos textos é um fenômeno de difícil mensuração, abordar as estratégias de apropriação, através da materialidade, do perfil de público e dos discursos publicitários é um caminho para tentar compreender o fenômeno editorial dos livros vendidos em bancas de jornais durante a década de 1970 pela Abril Cultural. A forma como as peças são apresentadas, em textos maiores, corrobora as considerações feitas por Baudrillard (2009, p. 179) acerca da propaganda: somos "[...] conquistados pela solicitude que se tem ao falar conosco, nos fazer ver, em ocupar-se conosco". O consumidor, ao ser informado pela Abril que foi "escolhido" para ter o "direito" a usufruir de um bem cultural, indispensável a "uma casa onde a cultura é respeitada", sente-se prestigiado e, vendo atendidas suas aspirações através do produto oferecido, torna-se predisposto a adquiri-lo. As 
bancas de jornais, disponíveis em grande quantidade nas vias de grande fluxo das cidades, cumprem o papel final no círculo: a venda ao leitor. 


\section{5 À VENDA EM TODAS AS BANCAS: A CIRCULAÇÃO BIBLIOGRÁFICA EM CANAIS ALTERNATIVOS}

\subsection{Dos pequenos jornaleiros às bancas de jornais}

O comércio de livros e periódicos em bancas e outros pontos espalhados pelas vias urbanas é uma atividade antiga e seu início confunde-se com o próprio desenvolvimento da impressão. Conforme Labarre (1981, p. 71), "depois de 1550, vê-se mesmo os capelistas venderem, em meio a mercadorias muito variadas, livros de Horas baratos e folhetos de algumas páginas, que descrevem novidades sensacionais ou acontecimentos prodigiosos". Os livros de Horas, em particular, constituíram um considerável mercado, não apenas entre letrados, mas também entre analfabetos. Em 1583, "Simmon Marion constata que o sucesso desses livros é tal, que 'um número infinito daqueles mesmos que não sabem ler sentiriam vergonha se não tivessem Horas'” (LABARRE, 1981, p. 72), anunciando que, já nos períodos iniciais da imprensa, os livros atendiam a necessidades subjetivas além da leitura de instrução ou lazer, estendendo o caráter pragmático para o campo simbólico.

Ainda no início do século XVII, aparece no Conto de Inverno de Shakespeare a figura do mercador de livros das ruas, representado pelo personagem Autolycus, "[...] que vendia baladas nos cruzamentos da cidade de Londres" (MOLLIER, 2009, p. 19). Cem anos depois, a comercialização do conhecimento já não era algo novo, mas é a partir desse período que se torna um grande negócio (BURKE, 2003). Em 1712, Paris contabilizava 120 mascates autorizados a negociar livretos na rua (MOLLIER, 2009, p. 22) e, em 1848, W. H. Smith \& Son "[...] abriam a primeira banca de livros de ferrovia, na estação de Euston, em Londres. [...] As bancas de livros [...] vendiam também revistas e jornais, para que os viajantes tivessem ampla escolha de material de leitura" (MANGUEL, 1997, p. 167).

No Brasil, o surgimento das bancas não está ainda bem estabelecido, mas provavelmente ocorreu em consequência da venda avulsa de jornais. O primeiro comércio deste tipo de que se tem notícia foi feito na cidade do Rio de Janeiro, 
então capital federal, em 185967, com a comercialização de "A Actualidade" (REBELLO, s.d) por escravos de origem africana, vindos da Costa do Ouro, que ficaram conhecidos como "minas" por serem inicialmente negociados para fazendas em Minas Gerais (BAHIA, 2015; REBELLO, s. d.). Em São Paulo, capital, a venda de jornais fora do sistema de assinaturas se deu, segundo Sodré (1999, p. 226-227), com "A Província de São Paulo", em 1876, comercializado pela primeira vez pelo ajudante de impressor Bernard Gregoire, através da utilização de buzinas para atrair a atenção dos transeuntes. "Logo depois, entretanto, os outros jornais acompanharam a inovação: surgiram os jornaleiros, depois as bancas e os pontos, e a disputa por pontos".

Durante o princípio do comércio ambulante de periódicos, o trabalho infantil, ainda sem qualquer controle, impunha a jovens de famílias humildes a desgastante tarefa de repassar à clientela, aos gritos e por longas horas, a folha de notícias do dia ou do período. Em 1926, o leitor Aguinaldo de Mendonça escreve ao Jornal do Brasili $^{68}$ solicitando ajuda ao dr. Mello Mattos $^{69}$ para os "pequenos jornaleiros", que "[...] procuram na venda dos jornaes o sustento de suas famílias". De um deles, ouviu Mendonça que, após o término de seu expediente, com receio de voltar para casa devido ao horário, "[...] encostava-se no batente da porta do ex-Odeon, ou dormia nos carros da Central do Brasil”. A esses meninos anônimos (Figs. 51 e 52), Heitor dos Prazeres escreveu, em 1933, a "Canção do Jornaleiro", em apoio à campanha do diário carioca "A Noite" pela melhora em suas condições de trabalho, cujo sucesso contribuiu para a fundação, em $1940^{70}$, da instituição que ficou conhecida como "Casa do Pequeno Jornaleiro 71 ":

67 Por volta de 1860, em Bahia (2015).

68 Jornal do Brasil, n. 127, de 29 mai. 1926, p. 10. Disponível em: <http://memoria.bn.br/DocReader/030015 04/46813 >. Acesso em: 09 nov. 2017.

69 Trata-se do jurista e professor José Cândido de Albuquerque Mello Mattos, primeiro juiz de menores do Brasil e da América Latina, que promulgou, em 1927, o também pioneiro código "para assistência e proteção à Infância e Adolescência", conhecido como "Código Mello Mattos". Disponível em: <http://www.migalhas.com.br/Quentes/17,MI47249,11049Primeiro+codigo+de+infancia+e+adolescencia+faz+80+anos+e+e+tema+de $>$. Acesso em: 09 nov. 2017.

70 Darcy Vargas, esposa de Getúlio Vargas, encabeça a campanha para arrecadar fundos e viabilizar a instituição, que tem por objetivo cuidar de menores jornaleiros e, posteriormente, meninos carentes. Mesmo com a deposição do marido em 1945, recusa-se a abandonar a instituição. Os detalhes da criação e dedicação de Darcy Vargas à Casa do Pequeno Jornaleiro 
Olha a noite,

Olha a noite,

Eu sou um pobre jornaleiro,

Que não tenho paradeiro,

$\mathrm{Ai}$, ninguém tem vida assim,

Digo adeus a toda gente,

Às vezes fico contente,

Ninguém tem pena de mim.

Eu vivo sempre a sofrer,

Óh, que destino é o meu,

Eu que fui sempre jogado,

Vou vivendo amargurado,

Óh que sorte Deus me deu.

Olha a noite,

Olha a noite.

Eu vivo sempre a sofrer,

Óh, que destino é o meu,

Eu, que fui sempre enxotado,

Vou vivendo amargurado,

Óh, que sorte Deus me deu.

Olha a noite,

Olha a noite.

Quando o sol vai se escondendo,

Eu vou me entristecendo,

Porque tenho coração,

Vivo sempre amargurado,

Como as folhas a meu lado,

Cumpri com a minha missão.

Eu vivo sempre a sofrer,

Óh, que destino é o meu,

Eu, que fui tão maltratado,

Vou vivendo amargurado,

Óh, que sorte Deus me deu.

Olha a noite,

Olha a noite,

Olha a noite,

Olha a noite.

podem ser obtidos em carta manuscrita de Alzira Vargas do Amaral Peixoto, filha de Darcy e Getúlio, disponível em <http://docvirt.com/docreader.net/FGV AVAP VPU/3439>. Acesso em 09 nov. 2017.

71 O verso "Olha a noite" é uma referência à chegada do alvorecer, mas também ao grito dos jornaleiros, oferecendo o jornal "A Noite". 
Figura 51 - Marc Ferrez - Jornaleiros

(Rio de Janeiro/RJ) (c. 1899)

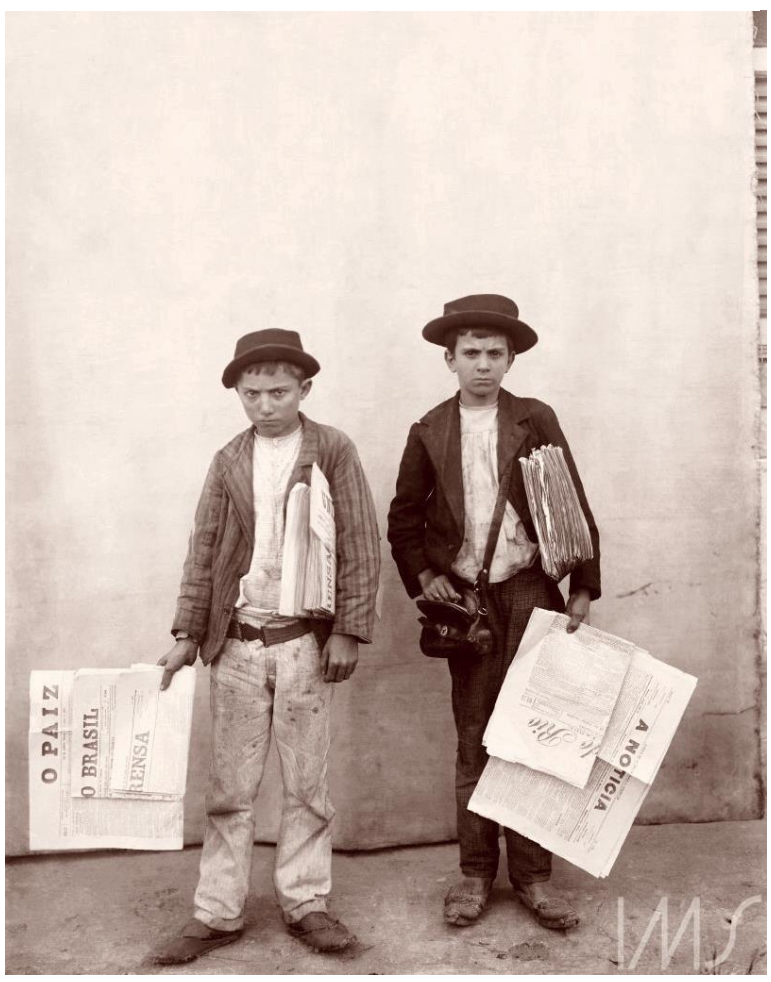

Fonte: Acervo Fotográfico Instituto Moreira Salles (IMS). Disponível em: $<$ http://fotografia.ims.com.br/>.

Acesso em: 09 nov. 2017
Figura 52 - Hildegard Rosenthal - Menino Jornaleiro (São Paulo/SP) (1939)

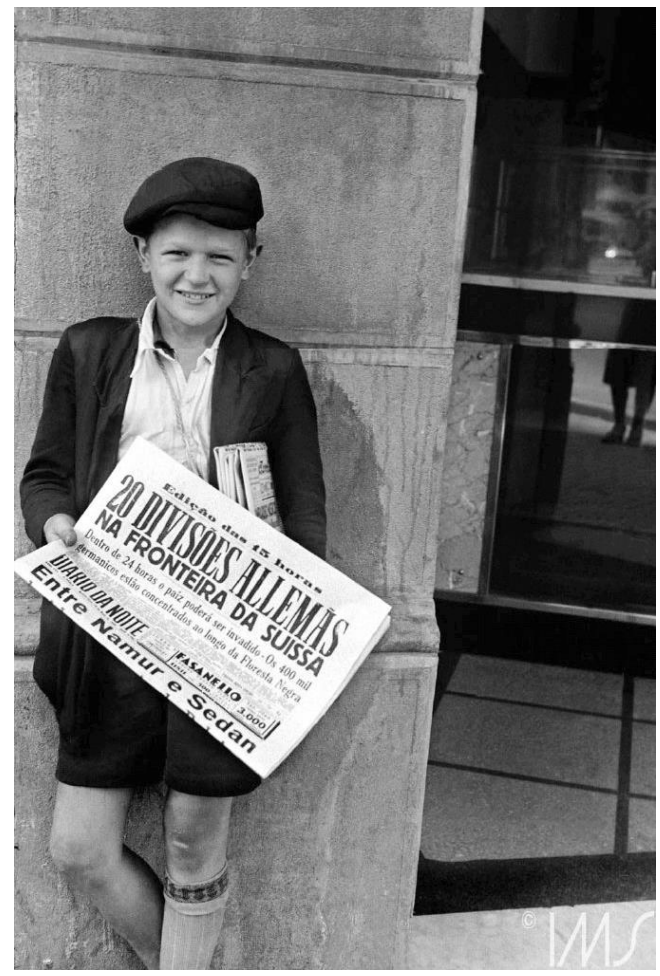

Fonte: Acervo Fotográfico Instituto Moreira Salles (IMS). Disponível em: $\frac{<\text { http://fotografia.ims.com.br/> }}{\text { Acesso em: } 09 \text { nov. } 2017}$

A primeira menção que se pôde encontrar com o termo "banca de jornaes", forma ortográfica vigente à época, foi em uma notícia veiculada em "O Século" (RJ), publicada em 26 de junho de 1907, informando que o italiano Salvador Cataldo, que possuía uma "[...] banca de jornaes no gradil do Theatro S. Pedro de Alcântara [...]", apresentou um mal-estar logo ao chegar em seu local de trabalho e, embora levado "[...] por um de seus empregados [...]" à farmácia Marques, na praça Tiradentes, não resistiu e faleceu logo depois (O SÉCULO, 1907, p. 3). Nota-se que já no início do século a profissão de jornaleiro era rentável o suficiente para que Cataldo possuísse funcionários, ainda que não se saiba o tipo de vínculo. Corrobora a ideia de que havia um bom retorno financeiro a esses primeiros comerciantes o fato de, em agosto de 1914, Constantino Sallo, dono de banca na praça da Bandeira, ter sofrido um acidente na "serra da Tijuca", quando retornava de um "convescote" 
(piquenique) em automóvel de sua propriedade, guiado por um motorista e um ajudante ${ }^{74}$, numa época em que ainda eram raros e caros os automóveis particulares (O IMPARCIAL, 1914, p. 9).

Em termos de estrutura, as primeiras bancas fixas eram constituídas por caixotes de madeira. A palavra "banca" para se designar os locais onde se vendiam periódicos tem origem nessa estrutura e no jornaleiro que a teria inicialmente utilizado. De acordo com Rebello (s.d.), conta-se que o italiano Carmine Labanca foi quem teve a ideia de empregar caixotes para expor os jornais que negociava em frente ao "Café Central", no Largo do Machado, Rio de Janeiro, conhecido como "Café Lamas" em referência ao sobrenome de seu proprietário, o português Manuel Thomé dos Santos Lamas. Os fregueses acostumaram-se com a compra feita no "Labanca", que se transformou em banca, mesmo que não haja nenhuma comprovação desta história.

De fato, é difícil traçar a origem do termo não só pela falta de documentação, mas pelo uso da palavra "banca" ser antigo e comum no país. O termo, conforme o Dicionário Houaiss, provém do italiano "banca" (1340), "inicialmente empregado com o sentido de 'tenda para vender mercadorias'". Por sua etimologia, pode-se pensar que tenha sido introduzido pelos primeiros italianos que trabalharam como jornaleiros e em outras atividades no país, mas a palavra, na acepção de barraca ou lugar onde se comercializa mercadorias, é de uso comum no Brasil pelo menos desde $1821^{75}$, muito antes do fluxo imigratório, como se vê.

No Rio de Janeiro, a palavra "banca" era também popularmente utilizada para designar os locais em que se recolhiam apostas para o jogo do bicho e, por vezes, as atividades de bicheiro e jornaleiro confundiam-se, como no caso de Salvador De Luca, que possuía uma banca de jornais no Largo da Cancella ${ }^{76}$. Parece-nos mais

74 Não há como afirmar, pelos elementos apresentados na reportagem, que se tratem de funcionários, apesar de ser plausível considerar que fossem.

75 A antiga Praia do Peixe, região de comércio de pescados e variedades no Rio de Janeiro, possuía diversas "bancas" onde os proprietários ofereciam seus produtos. Em novembro de 1821, o "Diário do Rio de Janeiro" apresentava um anúncio de um barco à venda "[...] na banca de Francisco Ferreira [...]. Disponível em: <http://memoria.bn.br/DocReader/094170 01/1085>. Acesso em: 09 nov. 2017.

76 Sua existência é comprovada por um empréstimo não quitado que fez a Candido de Freitas Washington, posteriormente cobrado à força através de espancamento, como noticiado em "A 
provável, portanto, que, por ser o termo comum bem antes de os jornais serem negociados de forma avulsa, os jornaleiros, ao adotarem a estratégia de fixarem-se em pontos de grande circulação, fizeram uso de "bancas", caixotes ou armações de madeiras, por vezes com tábuas de apoio para oferecer seus produtos, de forma que a estrutura ficou conhecida como "banca de jornais", o mesmo modo como as bancas de frutas, verduras, pães (Fig. Figura 53), camelôs e de muitos vendedores ambulantes que compunham a paisagem das cidades brasileiras naquele período.

Figura 53 - Vendedor de Pão Doce - Marc Ferrez - Rio de Janeiro (RJ) C. 1895

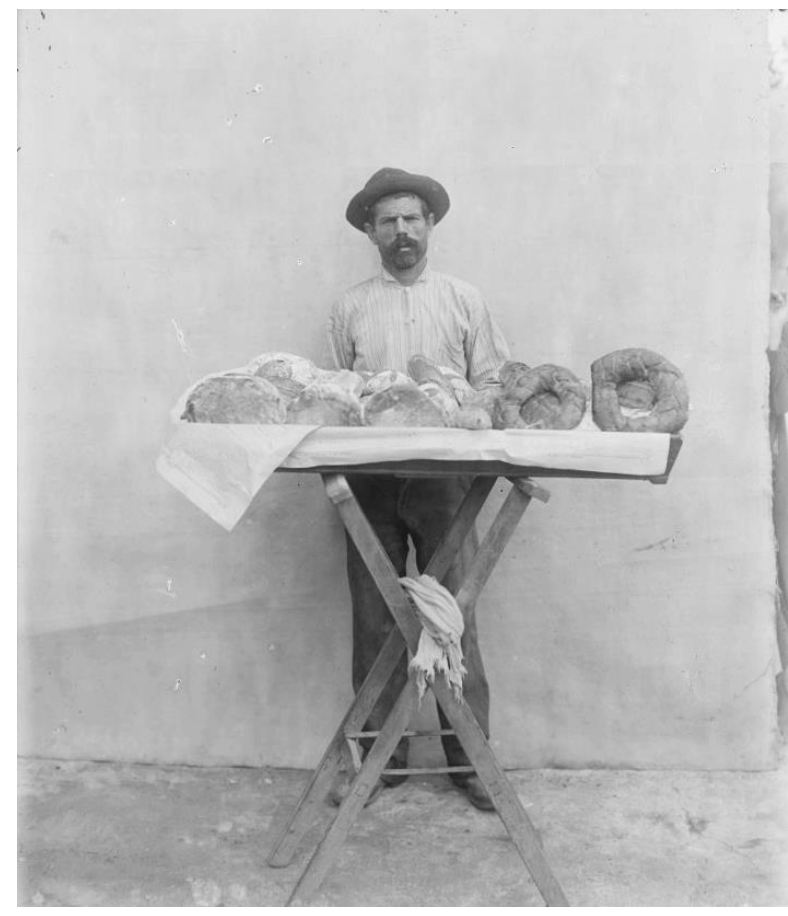

Fonte: Acervo Fotográfico Instituto Moreira Salles (IMS). Disponível em: <http://fotografia.ims.com.br/>. Acesso em: 17 nov. 2017

Dos improvisados caixotes de madeira e tábua, as bancas de jornais começam a se estruturar melhor no início do século XX. Se antes a maioria dos jornaleiros ainda perambulava a cidade em busca de fregueses, agora os pontos fixos vão se espalhando. $\mathrm{Na}$ av. Central (atual Rio Branco), Cesare (César) Bianco se estabelece e tem freguesia privilegiada, como o então senador Rui Barbosa, além de empregar meninos de rua para venderem periódicos na região. Hercule Imbroisi,

Noite", n. 2153, p. 1. Disponível em: <http://memoria.bn.br/DocReader/348970 01/11913>. Acesso em: 09. nov. 2017. 
nesse mesmo período, fixa sua banca na rua do Riachuelo, próximo ao número 184 (REBELLO, s. d.). Nos anos seguintes, as bancas de madeira foram se multiplicando, quase sempre de forma precária (Fig. Figura 54). A situação só começa a se modificar em 1954, quando, por iniciativa do prefeito de São Paulo, Jânio Quadros, é promulgada a lei ㄲo 4447, obrigando, a partir de então, que os jornaleiros se adaptassem às condições impostas pela instrução normativa. Apesar de não especificar um modelo a ser seguido, com a imposição da lei, proliferaram-se por São Paulo e outras cidades as bancas no formato de quiosques em metal como ainda hoje são construídas (CHAGAS, 2013).

Figura 54 - Banca de jornal no centro de São Paulo (SP)

- Alice Brill (c. 1953)

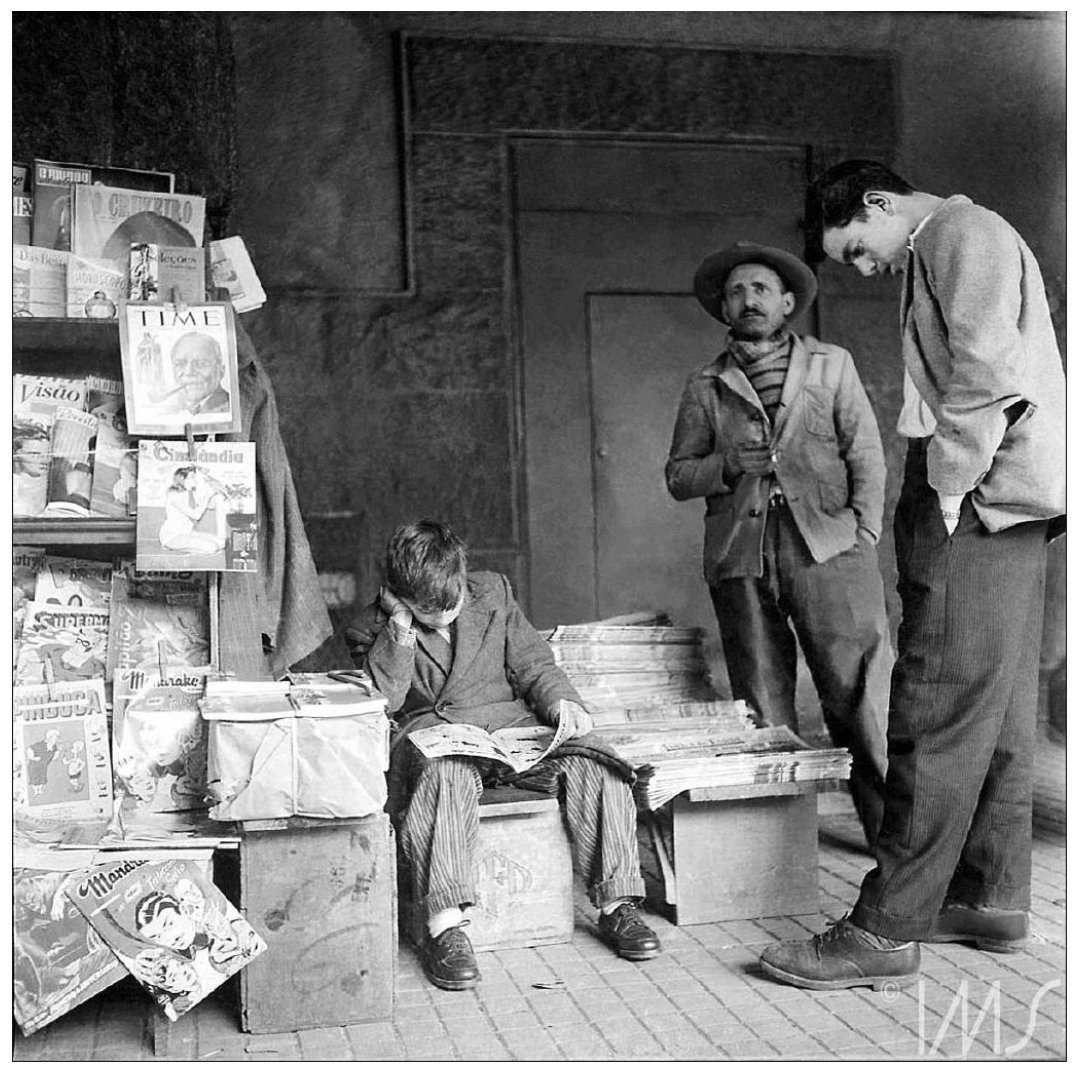

Fonte: Acervo Fotográfico Instituto Moreira Salles (IMS). Disponível em: <http://fotografia.ims.com.br/>. Acesso em: 17 nov. 2017. 


\subsection{Qual o lugar dos livros?}

Já com as bancas de jornal organizadas, no começo do século XX, Monteiro Lobato promove uma inovadora ideia para ampliar a circulação dos livros publicados por sua editora, ao propor, em uma carta enviada a comerciantes de todo o país, uma parceria para venda de livros através de consignação, o que garantiria ao revendedor a redução dos riscos de prejuízo e ao editor a possibilidade de estabelecer uma circulação e um público nacional às suas edições. A iniciativa de Lobato tinha um objetivo claro: ampliar a distribuição e os canais de venda para as publicações de sua editora, a "Monteiro Lobato e Cia". Sem tal ampliação, jamais poderia aumentar a tiragem, devido ao limitado número de livrarias existentes no Brasil e concentradas nas capitais, principalmente das regiões Sul e Sudeste.

A quantidade de leitores e a circulação dos livros sempre foi um gargalo para o mercado editorial brasileiro. Se a alfabetização, a partir dos anos 1950 e 1960, havia reduzido o contingente daqueles incapazes de ler, o problema do número de estabelecimentos formais para a venda das publicações ainda estava por resolver. A banca surgiu, em vista disso, como uma alternativa natural para a comercialização de livros em grande volume, modelo de distribuição, no entanto, muito mais antigo que as primeiras coleções da Abril.

Entre 1940 e 1942, a "Folha da Manhã" (atual Folha de São Paulo) editou em brochuras $^{77} \mathrm{com}$ mais de 100 páginas, no tamanho $24 \mathrm{~cm}$ por $22 \mathrm{~cm}$, caricaturas políticas de Belmonte (Música, Maestro!; A Guerra do Juca), publicadas originalmente na Folha da Manhã e Folha da Noite, com distribuição em bancas de jornais, da mesma forma que os periódicos da empresa. Ainda na década de 1940, a chamada "literatura clandestina", de caráter erótico/pornográfico, era vendida em algumas bancas do Rio de Janeiro, já previamente conhecidas pelo público consumidor destas edições ${ }^{78}$.

Em 1953, a Librairie Hachette inaugura sua sucursal no Rio de Janeiro, denominada "Librairie Hachette S. A. do Brasil", assumindo a "[...] distribuição das

77 Embora com formato semelhante a revistas em quadrinhos.

78 Folha de São Paulo, 15 jun. 1943, p. 3. Disponível em: <https://acervo.folha.com.br/index.do>. Acesso em 18 nov. 2017. 
Publicações Francesas no Brasil, por intermédio das livrarias e bancas de jornais"79, ampliando a circulação de periódicos e livros franceses antes restritos a importadoras especializadas. A Hachette, conforme Labanca (2009), ofereceria, na década seguinte, acordos para que jornaleiros possuíssem estantes metálicas giratórias, conhecidas como racks, onde os livros eram ofertados em espaço separado aos do restante da banca, evitando a concorrência visual direta com outras publicações.

Três anos depois, a Monterrey iniciou a publicação de livros de bolso, com a série $O$ Coyote, de histórias de faroeste traduzidas do espanhol, também comercializados em bancas de jornais (LABANCA, 2009). Na década de 1960, a Editora especializou-se em obras de espionagem, muito populares naquele momento em que a Guerra Fria estava em seu auge. Em 1967, procurando diversificar e atingir um público interessado em outros temas, inicia a coleção "Avec", composta por coletâneas de contos clássicos de autores consagrados da literatura estrangeira, mas que não abandonam a estética das chamativas capas (Fig. Figura 55), muitas desenhadas pelo reconhecido artista brasileiro Benício ${ }^{80}$.

79 Correio da Manhã, no 18539, 01 set. 1953, $1^{\circ}$ Caderno, p. 9. Disponível em: http://memoria.bn.br/DocReader/089842 06/29539>. Acesso em: 18 nov. 2017.

80 José Luiz Benício da Fonseca, mais conhecido como Benício, é um artista gráfico brasileiro. Criou diversas capas de discos e livros, realizou ilustrações para cartazes de cinema, peças publicitárias e revistas de circulação nacional. Gonçalo Júnior conta sua trajetória em "E Benício criou a mulher...", publicado pela editora “Opera Graphica” em 2014. 
Figura 55 - Capas de exemplares da Coleção Avec
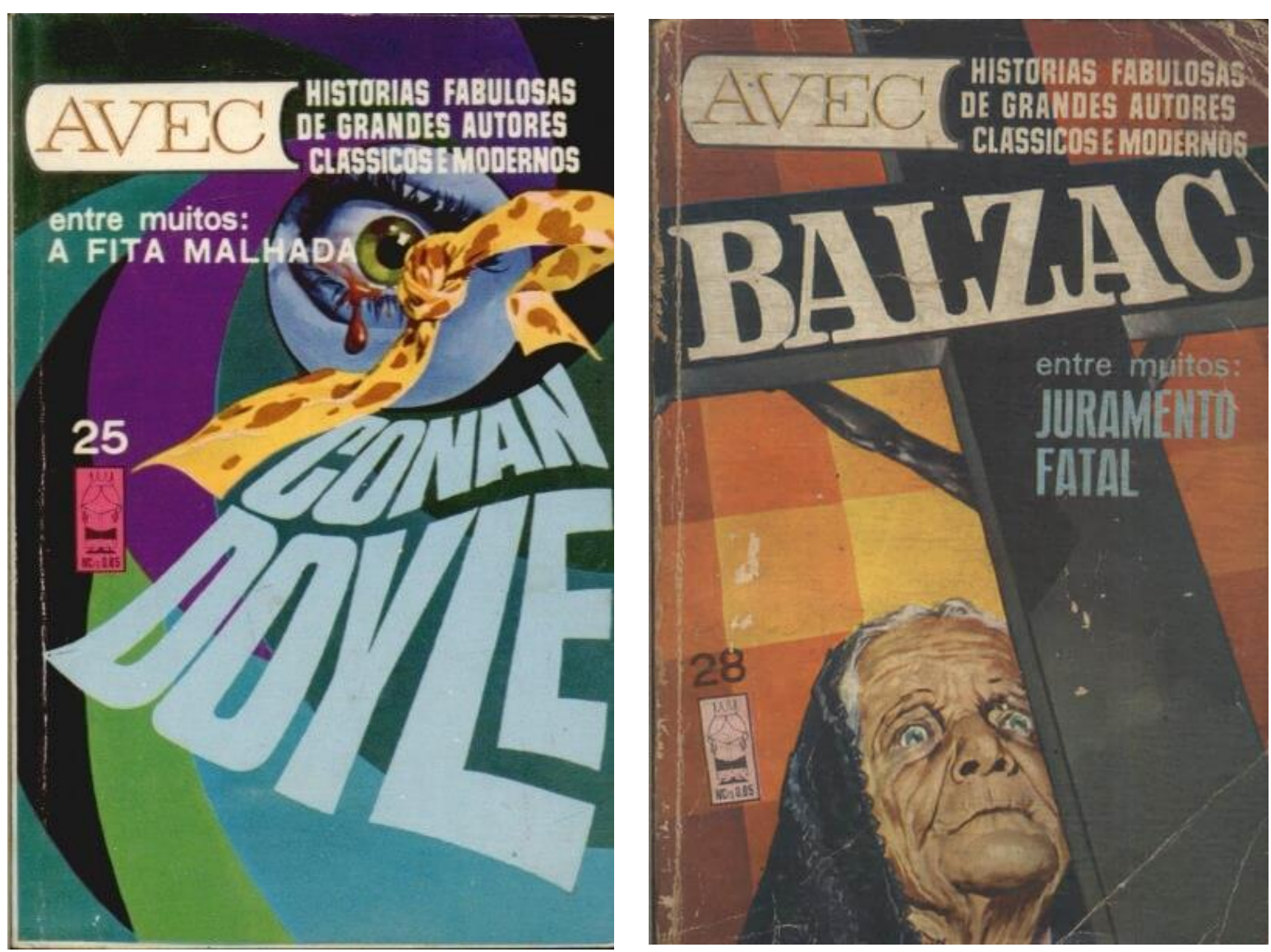

Fonte: Livraria Traça. Disponível em: <www.traca.com.br>. Acesso em: 21 nov. 2017.

Em 1961, a Tecnoprint lança sua coleção "Edições de Ouro", precedidas, na década de 1950, pelos pequenos livros da coleção "Edições Segredo" (LABANCA, 2009), formada por generalidades e clássicos da literatura, que havia recebido críticas negativas pela apresentação de textos condensados e capas apelativas (Fig. Figura 56):

Quando o livrinho consiste numa história policial sem importância literária, admite-se [...] [a] exploração barata dos instintos. Mas quando o livro é uma condensação de grande obra literária (como 'Madame Bovary', de Flaubert, 'A Carne', de Júlio Ribeiro, 'A Besta Humana', de Zola, 'O Primo Basília [sic]', de Eça, que qualquer pessoa hoje encontra nos jornaleiros), 0 sensacionalismo da capa e a condensação em si merecem repulsa de quantos respeitam e amam a verdadeira literatura" (ABSURDO, p. 6). 
Figura 56 - Capas de exemplares da "Edições Segredo"

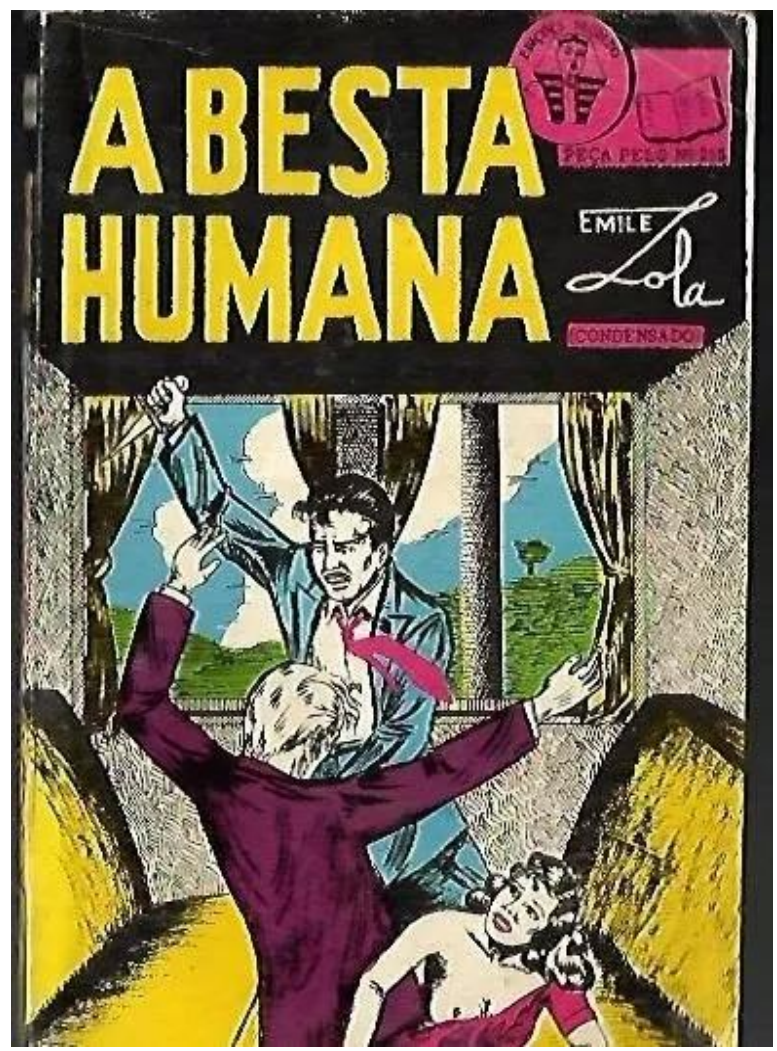

Fonte: Mercado Livre. Disponível em: $<$ https://produto.mercadolivre.com.br/MLB904935049-a-besta-humana-emile-zola- JM> Acesso em: 21 nov. 2017.

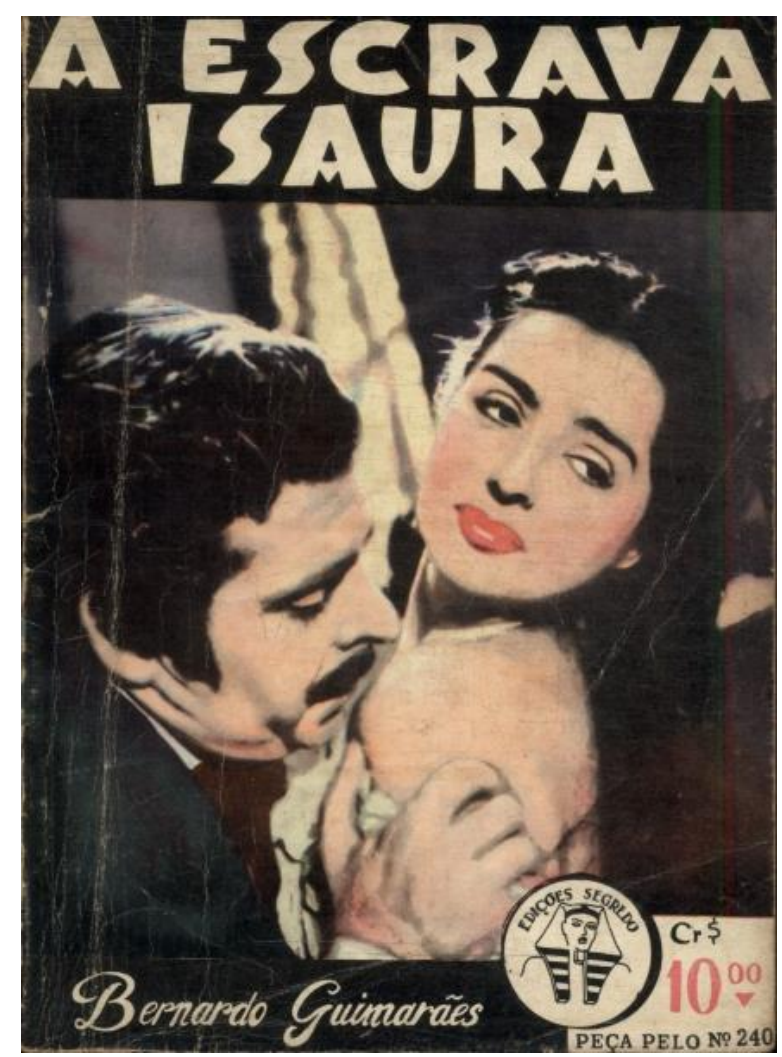

Fonte: Livraria Traça. Disponível em: $<$ www.traca.com.br>. Acesso em: 21 nov. 2017.

Recepção diferente teve a Edições de Ouro na mesma coluna do Diário Carioca (LITERATURA, 1961, p. 6). Uma nota publicada pouco após a edição dos primeiros títulos aponta que a redação havia recebido exemplares das "[...] 'Edições de Ouro', que sempre víamos de passagem nas bancas de jornais" e identifica a presença de "[...] inúmeras obras de valor literário e educativo indiscutível [...]", entre os quais encontram-se A Muralha, de Dinah Silveira de Queirós, e Meu Guia Ortográfico, de Sá Nunes. Mas o que chamou a atenção foi "[...] a grande quantidade de livros policiais interessantíssimos [...]", cujas "[...] cuidadas traduções [...]" davam ao leitor brasileiro a mesma sensação que experimentavam os ingleses com o mesmo tipo de ficção. Nas Edições de Ouro, a Tecnoprint popularizou a 
literatura brasileira em livros de bolso vendidos em bancas de jornais ${ }^{81}$ e introduziu em nosso mercado editorial obras de ficção científica produzidas por autores nacionais, através da séria Futurâmica ${ }^{82}$. Uma estratégia inédita e incomum implementada pela editora eram as "faixas de preço", classificadas por um selo que definia o valor do exemplar em comparação a outros da mesma categoria, de acordo, principalmente, com a quantidade de páginas, evitando a defasagem do valor impresso nas capas nos momentos de alta inflacionária.

Em 1969, a tradicional distribuidora Fernando Chinaglia implantou uma nova forma de se vender livros em bancas: o crediário. O leitor poderia comprar obras de "[...] 30, 40 e até 50 cruzeiros novos [...]" através de uma pequena entrada e o restante a prestações ${ }^{83}$, permitindo que a moda do crediário, então em voga para bens de consumo como televisão, geladeiras, enceradeiras, entre outros, chegasse também ao universo dos livros (DIÁRIO DE NOTÍCIAS, 1969, p. 16).

Assim, mesmo antes do lançamento de Papillon e Os Imortais da Literatura Universal pela Abril, as bancas de jornais há muito ofereciam também livros, de todos os gêneros, mas que guardavam em comum a característica do acabamento em brochura, geralmente de baixa qualidade e pequeno formato. $O$ comércio de rua, no qual também se incluíram o de livros, tem origem na oferta especialmente de produtos populares e está associado à cultura de massas. A banca de jornais, onipresente nas grandes cidades, nas vias entre a casa e o trabalho, no caminho até o ponto de ônibus ou o suburbano, manifesta-se a todo instante e pulula à vista com sua enorme oferta de livros, fascículos e periódicos, muitas vezes pôsteres de lançamentos que, mais que pedir, praticamente obrigam à atenção do transeunte.

Já em março de 1964, uma nota no Diário Carioca indicava que havia "[...] nada menos de mil bancas de jornais" apenas na Zona Sul do Rio de Janeiro. Ainda que pareça um pouco exagerado, o número simboliza a dimensão do crescimento

81 LITERATURA R. J. Diário Carioca, Rio de Janeiro, 11 fev. 1961, p. 6. Disponível em: <http://memoria.bn.br/docreader/093092_05/5038>. Acesso em: 20 nov. 2017.

82 LITERATURA R. J. Diário Carioca, Rio de Janeiro, 03 fev. 1961, p. 6. Disponível em: <http://memoria.bn.br/docreader/093092_05/4934>. Acesso em: 20 nov. 2017.

83 Diário de Notícias, 02 fev 1969, 1a. Seção, p. 16. Disponível em: <http://memoria.bn.br/DocReader/093718 04/80933>. Acesso em: 18 nov. 2017. 
deste tipo de ponto comercial nas cidades brasileiras. "Quem lê tanta notícia?" diria Caetano em 1968. Enquanto as bancas se multiplicavam, as livrarias eram raras (como ainda são), do mesmo modo que a parcela da população habituada à prática da leitura, recreativa ou técnica. Escondidas atrás de vitrines, livrarias com frequência poderiam ser confundidas com outras das milhares de lojas que ofertavam mercadorias diversas. A banca do jornal, da revista, dos quadrinhos, do cartão-postal e também dos livros, parecia muito mais integrada e contextualizada ao cotidiano popular, e menos assustadora para o leigo que não sabia o que responder ao atendente de livraria que lhe perguntava: "precisa de algo?"

Conforme Dessauer (1979, p. 46), as livrarias e outros canais tradicionais em comércio de livros são considerados "pontos de venda". Já bancas de jornais e outros canais alternativos de distribuição, como supermercados e cadeias de lojas, compreendem o "mercado de massas". O problema da escassez de pontos de venda era representativo da elitização do hábito de se comprar livros. Segundo dados do SNEL, mencionados por Hallewell (2005), havia, em 1972, concentradas nas regiões Sul e Sudeste, economicamente mais representativas, apenas 600 livrarias no país, que, ademais, mostravam-se despreparadas para receber o leitor:

\begin{abstract}
As livrarias são geralmente maldispostas, sem nenhum atrativo, entulhadas, e os livros, por isso, praticamente escondidos. Os balconistas estão despreparados, não conhecem seu estoque, e o leitor não possui nenhum guia para localizar o título de que necessita. Há livreiros que dispõem os livros segundo a editora, e assim reúnem, por exemplo, Teoria Microeconômica e $O$ ensino funcional da datilografia na mesma estante, pelo simples fato de serem editados pela Fundação Getúlio Vargas. Há os que arrumam segundo o autor, outros pelo assunto (aqui são cometidas as mais hilariantes heresias), mas há até os que arrumam suas prateleiras segundo o formato...

Infelizmente, nossas livrarias, em regra, não são instrumentos de venda de livros, mas locais onde eles são comprados. Repetem-se nelas, na era da tecnologia e da televisão, dos cassetes e dos vídeo-cassetes, os mesmos processos de venda que tornaram famosas as antigas Francisco Alves e Garnier. Mudam-se os tempos, os métodos, não. (VIEIRA, 1975, p. 207208)
\end{abstract}

Em contrapartida, as bancas de jornal, presentes em maior número e em todo território nacional, surgiam como canal de distribuição ideal a edições populares de grande tiragem. Os itens eram mais facilmente encontrados, devido ao próprio limite do espaço, e a propaganda cuidava de direcionar parte dos compradores já com o 
pedido na ponta da língua. As livrarias, pela forma como eram organizadas e pelo status elitizado de que dispunham, tornavam-se barreiras à grande parcela da população que, composta por indivíduos historicamente excluídos do hábito de as frequentarem, privavam-se, por conseguinte, do acesso a livros que não apresentassem unicamente temáticas ligeiras e de rápido consumo disponíveis em outros canais de venda. Mesmo aqueles habituados às livrarias, devido à precariedade delas, poderiam experimentar dificuldades na compra de determinado título. Seu maior trunfo, a diversidade, acabava arruinado pelos inadequados métodos de organização e exposição, potencializados pelo despreparo dos funcionários, ao contrário do que ocorre com os jornaleiros, como veremos. José Fernando de Barros Martins, da Livraria Martins Editora, era, em 1969, ainda mais categórico: "nem para se esconder da chuva o povo brasileiro entra em livraria. Essas lojas são, em geral, rançosas, não atraem clientes novos. A mercadoria é mal exposta, o vendedor não deixa o comprador à vontade" (O LIVRO..., 1969, p. 25).

As bancas, valendo-se do público "descartado" pelas livrarias, viram seu movimento aumentar. Para se ter ideia do crescimento apresentado pela venda de livros por este canal, em 1973, 2,2\% das obras comercializadas no país ocorria nesses estabelecimentos, valor que saltará quase dez vezes, alcançando o expressivo número de 20,9\% em 1979, apenas seis anos depois (REIMÃO,1996, p. 62-63). Boa parte do sucesso que as bancas experimentaram foi devido ao perfil das editoras que publicavam obras para circularem no "mercado de massa". Vieira (1975, p. 210) aponta que os editores brasileiros tradicionais, bem como as livrarias, não inovam em suas estratégias e não se utilizam adequadamente dos meios de comunicação, pois

[...] a maioria desconhece a colaboração da imprensa, limitando-se a distribuir alguns exemplares com os titulares da crítica literária, de público discutível, não se dando ao trabalho, sequer, de encaminhar suas publicações acompanhadas de um press-release.

\subsection{O livro na banca de jornais}

O contista Dalton Trevisan iniciou sua carreira editando por conta própria seus livros e os distribuindo em banca de jornais. Ivo Nalce (1972, p. 2), ao comentar a volta do escritor curitibano às bancas, naquele momento já consagrado e publicado pela Civilização Brasileira, tem dúvidas se elas influíram de alguma forma na 
consolidação de seu estilo, mas estava certo de que ajudaram "[...] bastante para aumentar o número de seus leitores. Um escritor deve ser lido [...]". Nalce era otimista com este tipo de circulação, pois

não importa que alguém compre o Rei da Terra pensando ser um livreto
policial ou pornográfico - como é o caso da maioria dos livros à venda em
bancas. O importante é que estarão levando boa literatura para casa e, se
gostarem voltarão às bancas, ou às livrarias, para buscar mais (NALCE,
1972, p. 2).

A venda de livros em bancas de jornais era algo que já estava bem estabelecido no começo dos anos 1970, e muitos autores que antes poderiam ser vistos com desconfiança por terem suas obras em pontos alternativos agora eram considerados inovadores, ainda que a opinião de parte dos leitores não fosse tão positiva quanto à de Nalce. O bom momento que vivia o comércio dos livros em bancas se deve, sem dúvida, à distribuição. O surgimento dos distribuidores foi fundamental no aumento da circulação bibliográfica. Embora fossem mais um elemento de custo na cadeia, possibilitaram que regiões antes inacessíveis aos editores, devido à distância do centro de produção, passassem a ser atendidas e o processo de reposição dos estoques facilitado, eliminando o trabalho extra e possibilitando a dedicação exclusiva aos processos editoriais e comerciais.

Os editores brasileiros, entretanto, dependiam dos serviços prestados por distribuidoras terceirizadas para disseminarem pelo país suas publicações. A Abril tinha um trunfo, como se observou no capítulo 2: desde 1961 era proprietária da Distribuidora Abril, que além de disseminar as edições da empresa, também oferecia seus serviços a outras editoras. Quando os primeiros livros completos foram lançados, portanto, a Distribuidora Abril já tinha quase dez anos de funcionamento e havia organizado uma eficiente rede de revendedores e distribuidoras regionais, que os faziam chegar a praticamente qualquer lugar do país onde também estivessem revistas como Veja, Claudia, Quatro Rodas, Pato Donald, entre outras publicações dos Civita. O domínio de boa parte da cadeia de circulação do livro (produção, impressão e distribuição) permitia ganhos em escala, além de um controle muito mais rígido sobre cada produto comercializado. Repartes (quantidade de exemplares a serem vendidos em cada banca), devoluções e comissões sobre vendas eram 
organizados pela própria empresa, otimizando os processos e reduzindo perdas, o que refletiu no aumento do lucro e na oferta de preço competitivo no mercado ${ }^{84}$.

O distribuidor também foi essencial na manutenção do processo de aquisição dos exemplares. Durante ou ao fim das coleções, caso o colecionador perdesse um ou mais números, poderia solicitá-los ao jornaleiro ou à distribuidora responsável por abastecer as bancas de sua região. Essa disponibilidade diminuía a possível desistência no decorrer das publicações, já que a falta de determinados números, sem a perspectiva de adquiri-los, talvez levasse o comprador a perder o interesse em continuar a compra dos volumes posteriores.

Cada banca de jornais que trabalhava com produtos Abril era atendida pela Distribuidora de forma direta ou pelas regionais que a ela prestavam contas, estabelecendo um relacionamento muito próximo aos jornaleiros, personagens centrais no processo de venda das coleções e outros produtos culturais. Victor Civita sempre deu valor a este aspecto e, como vimos, nos primeiros anos da Abril fazia questão de ir pessoalmente visitar cada dono de banca e inspecioná-las. O fato de muitos daqueles profissionais serem compatriotas de Civita certamente facilitou o processo e deu visibilidade extra à pequena Editora que então estava começando a atuar no país. Anos depois, já com maior poder político e econômico, a Abril teve papel fundamental no aumento de concessões a bancas, assim como financiou a ampliação e compra da estrutura para aqueles que não tinham condições de custear o investimento.

A afinidade com os jornaleiros era essencial por dois fatores, no que tange às coleções de livros da Abril: 1) os profissionais poderiam informar sobre o lançamento e oferecer os exemplares aos fregueses; 2) como existia uma curva de declínio para os volumes da série, com base na comercialização do primeiro número, era indispensável contar com a frequente promoção dos vendedores nas bancas para reduzir o nível da queda que haveria durante os títulos subsequentes. O contato entre o consumidor e seu jornaleiro é, da mesma maneira que as formas tradicionais

84 Roberto Civita defendia que cada empresa dentro do conglomerado Abril era um "profit center", um centro de receitas. Para ele, cada unidade deveria manter-se independente, embora respondendo aos mesmos executivos, com orçamentos e metas próprias. Caso uma empresa, ainda que fosse da Abril, desejasse utilizar os serviços de outra, também do grupo, deveria pagar por eles. 
de publicidade, uma eficiente estratégia de divulgação, devido à maior intimidade com a clientela que os atendentes de livraria. Conhecendo gostos e capacidade de compra, além de contar com um estabelecimento onde não estão presentes tantas formalidades, o jornaleiro seria capaz, dessa maneira, de casualmente indicar um exemplar da Abril durante a comercialização de outros produtos. Era, por isto, essencial no processo ativo e passivo da propaganda, tanto comunicando sobre produtos como recebendo e concluindo a venda ao cliente anteriormente comunicado.

Como mercadoria, o livro faz parte "[...] dos mecanismos econômicos próprios ao capitalismo" (LAJOLO; ZILBERMAN, p. 60) e, por isso, a indústria editorial não deve desconsiderar relação intrínseca entre a propaganda e a distribuição, como evidencia John Dessauer (1979). Para o autor, de nada adianta haver divulgação se o consumidor não encontra o produto disponível para compra. Explicita seu raciocínio ao usar a metáfora do motor, onde a propaganda

é para o conjunto da distribuição o que a graxa e o óleo são para o motor: os lubrificantes necessários que fazem o motor funcionar com maior suavidade e melhor desempenho. Se o motor tem pouca força, é antiquado ou esta está em mau estado de conservação, de pouco adianta pôr-lhe mais óleo e graxa para melhorar seu desempenho (DESSAUER, 1979, p. 197).

Desta forma, a eficiência do uso da banca e da boa distribuição das edições, aliada a campanhas de divulgação, pode ser conferida no relato em que Fernando Almada (1975) narra sua experiência ao presenciar a venda de um exemplar da coleção Os Imortais da Literatura Universal em uma banca de bairro, um verdadeiro encontro entre a propaganda e a circulação:

Certo cidadão, após pedir um jornal especializado em esportes,
perguntou se o jornaleiro recebera algum livro novo da série Os
Imortais da Literatura Universal, pergunta, naturalmente, feita
de modo simples. O jornaleiro exibiu-lhe o exemplar recém-
recebido, o homem leu o nome do autor, declarou desconhecê-
lo e comprou o livro. É quase certo que o cidadão jamais
tivesse entrado numa livraria. E veio encontrar-se com a
literatura numa modesta banca de jornal de bairro, já
estimulado pela campanha de propaganda conduzida"
(ALMADA, 1975, p. 246-247).

A narrativa de Almada é descrição privilegiada de um processo que ocorria com frequência na comercialização das coleções da Abril, a compra de um exemplar por um consumidor que havia tido contato prévio com algum tipo de publicidade da 
Editora e aproveitou a visita costumeira à banca para, além de comprar o habitual periódico esportivo, adquirir o volume em circulação de "Os Imortais [...]". Como uma espécie de espaço cultural popular, em que a frequência conduz à intimidade, a banca permite que se desconstrua a hierarquia social e cultural relacionada às livrarias, por exemplo, e se cative o leitor não iniciado à literatura de cunho erudito à compra deste tipo de ficção.

Escarpit (1976, p. 125-126) segmenta esses dois circuitos, o das livrarias tradicionais, como "circuito letrado", e o das drogarias e lojas de departamento (ao qual adicionamos também bancas de jornais), como "circuito popular". Ainda que seja evidente que não haja nenhuma lei que restrinja o acesso às livrarias, os "[...] próprios horários e necessidades geográficas [...]" se encarregam de nelas limitar a frequência de boa parte da população, por não se encontrarem no circuito dos trabalhadores, ou seja, "[...] nos trajetos de sua vida cotidiana, o trabalhador não tem praticamente nunca a oportunidade de passar por uma livraria quanto [sic] [quando] ela está aberta, ou, quando tem, não está suficientemente motivado para entrar e comprar um livro". A banca e outros pontos de vendas de livros do "circuito popular", como bem demonstra o relato de Almada, cumprem função inversa: estão sempre no circuito do fluxo cotidiano e neles a motivação de comprar o jornal para leitura diária (e junto um oportuno livro) é maior do que frequentar o desconhecido "circuito letrado" das livrarias, no qual boa parte da população não se sente incluída.

Compreendidos os agentes motivadores e desmotivadores da frequência às livrarias e bancas de jornais, convém apontar a valiosa característica que as bancas têm como canal de propaganda das coleções da Abril: sua própria estrutura como meio privilegiado de publicidade. Ao exporem os exemplares, seja dentro ou nas laterais (Fig. Figura 57), havia o contato visual com os volumes pelas bancas de toda cidade. Para auxiliar na utilização destes espaços como canais de publicidade, a Abril cedia, através de sua Distribuidora, cartazes e bandeirinhas que deveriam ser afixados para a divulgação dos lançamentos, como informado no capítulo anterior ${ }^{85}$.

$85 \mathrm{Em}$ alguns casos, os cartazes eram arrancados das bancas, provavelmente para serem utilizados como objetos de decoração. A saída para alguns jornaleiros era virar as peças e escrever à mão sobre a disponibilidade de determinada obra, conforme afirmou Darlan Pedro da Costa (OS LIVROS..., 1974). 
O bom relacionamento com o jornaleiro, somado às peças a eles direcionadas, salientando os lucros que as coleções poderiam oferecer, possibilitaram à Editora ocupar posições privilegiadas na exposição dos produtos, permitindo ao frequentador conhecer suas edições, caso não tivesse ainda sido previamente atingido pela propaganda.

Figura 57 - Banca de jornais na Praça da Sé (SP) com produtos expostos Domingos de Miranda Ribeiro - 1966

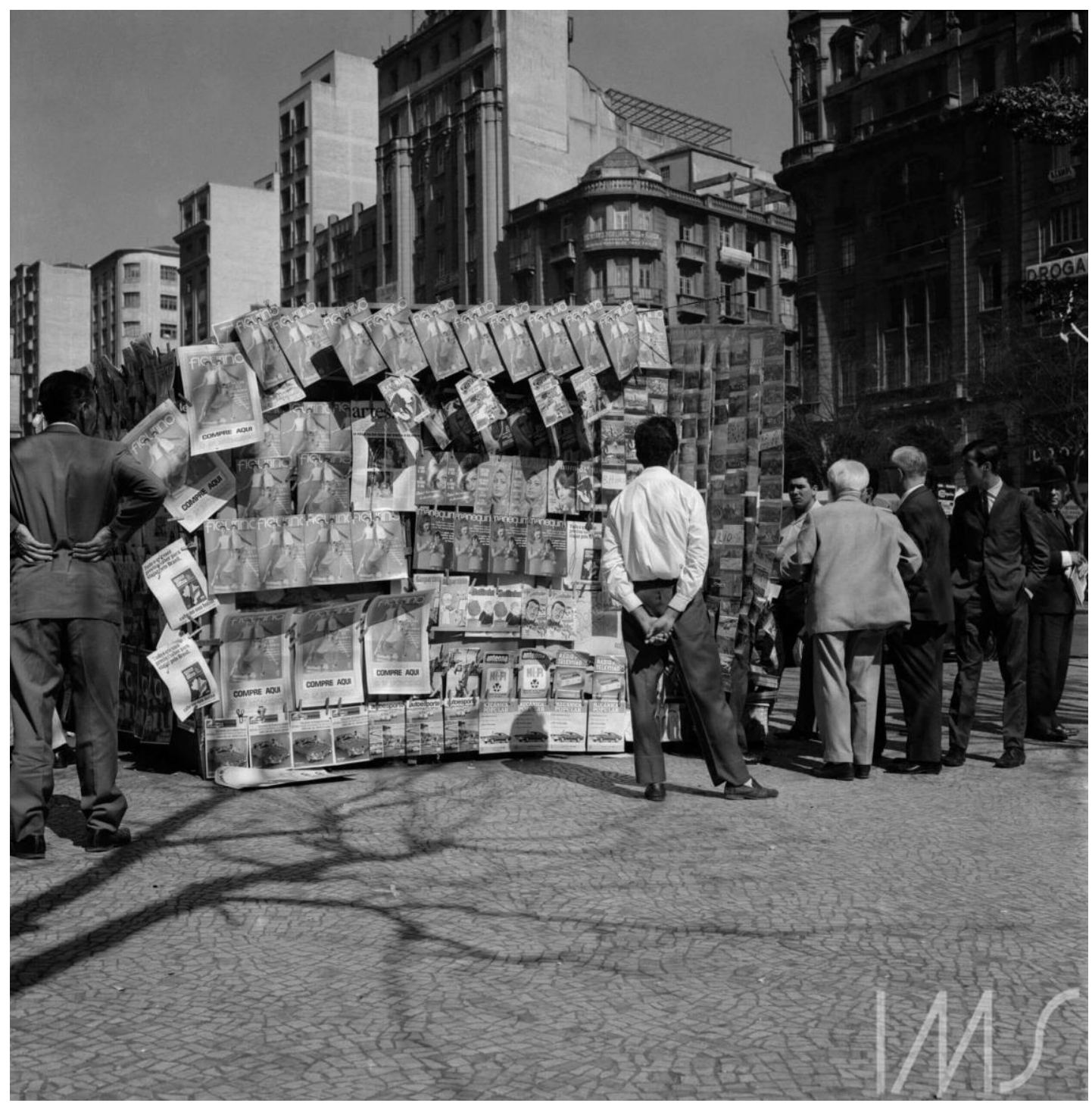

Fonte: Acervo Fotográfico Instituto Moreira Salles (IMS). Disponível em: $<$ http://fotografia.ims.com.br/>. Acesso em: 23 nov. 2017 
A exposição dos volumes, frequentemente associada à facilidade na venda, era um fator muito trabalhado pela Distribuidora junto ao jornaleiro. Tanto que as peças para informação dos lançamentos com frequência abordavam o assunto. $A$ Figura Figura 58 apresenta o fragmento de uma promoção voltada aos jornaleiros em que se pode identificar as estratégias de exposição, oferta e propaganda atuando em conjunto para potencializar as vendas. Observa-se a recomendação de que as "[...] coloridas capas dos fascículos [...]" sejam empregadas como meio de divulgação, despertando o interesse do transeunte. Ao freguês acostumado à compra de jornais, é sugerido que se ofereça a coleção, comunicando-o da temática, relevância e dinâmica de publicação que o profissional já havia previamente estudado. Aqui, ao contrário do cliente do relato de Almada (1975), que já conhecia o

Figura 58 - Fragmento de peça publicitária voltada a jornaleiros onde se salienta a importância da exposição adequada dos exemplares

produto, cabe ao jornaleiro apresentá-lo, embora boa parte já chegue à banca propenso à compra devido à "[...] boa campanha publicitária que será feita na televisão".

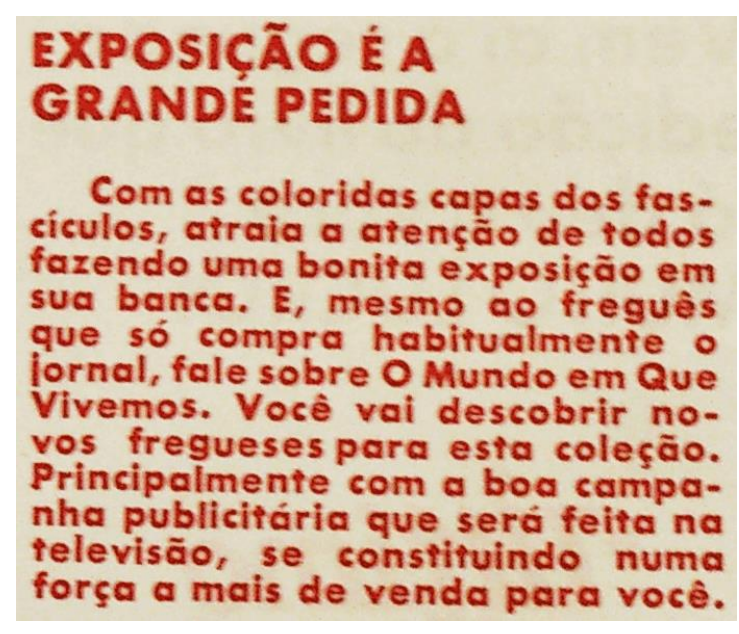

Fonte: DEDOC Abril.

Consequentemente, mesmo o comprador que não procurasse os livros colecionáveis da Abril poderia ser interpelado pelo jornaleiro com oferta dos volumes. As peças de divulgação, informando elementos básicos de cada série, 
como sua temática, qualidades, periodicidade, entre outros, preparava-o para que pudesse solucionar qualquer dúvida que representasse resistência à compra. Em alguns casos, quando eram oferecidos brindes em determinados exemplares, 0 jornaleiro os recebia e podia demonstrá-los ao público, despertando o interesse pelo desenvolvimento da coleção (Fig. Figura 59), que frequentemente fazia uso destes tipos de "atrativos" para "amarrar" o leitor ao processo contínuo de compra, conforme apontamos anteriormente.

Figura 59 - Brindes oferecidos junto à coleção A Grande Aventura do Homem encaminhados aos jornaleiros para demonstração ao cliente

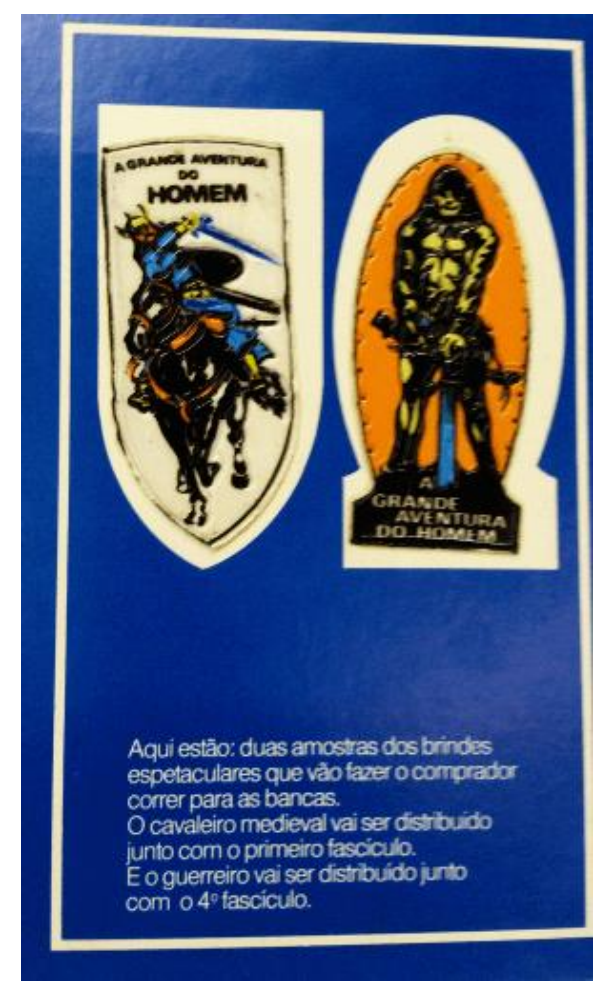

Fonte: DEDOC Abril.

Como os donos de banca tinham, em teoria, liberdade para recusar publicações em que não acreditassem haver bom nível de vendas, a Distribuidora Abril, a cada novo lançamento, investia em peças para convencê-los a apostar no produto e solicitar maior número de exemplares no reparte. $E$ isso ocorria não apenas com obras da própria Abril, mas também com as de outras editoras que 
utilizassem seus serviços. Um exemplo é o relançamento de $O$ Último Tango em Paris, de Robert Alley, publicado pela Civilização Brasileira em 1973 e distribuído pela Abril. O romance, baseado no polêmico filme homônimo de sucesso estrelado por Marlon Brando e Maria Schneider, vendeu 100.000 cópias em apenas 20 dias em todo o Brasil. Reimpresso, o livro foi censurado pelo Ministro da Justiça Alfredo Buzaid. Na peça promocional, ofertada aos jornaleiros pela Distribuidora sob o título de "Vai continuar o tango do lucro", os profissionais são informados de que "o livro mais vendido dos últimos tempos volta para atender os milhares de leitores que não puderam comprar antes [...] trazendo mais lucros para você. Vai ser uma 'moleza' vender essa edição. Avise desde já os seus fregueses. Reforce seu reparte". Como é possível notar, identifica-se, na peça, três elementos fundamentais para a boa comercialização do livro: estímulo ao jornaleiro ("lucro" e "moleza vender"), propaganda ("avise [...] seus fregueses") e disponibilidade ("reforce seu reparte"). Desse modo, o vendedor, sentindo-se estimulado pela perspectiva de ganho sem muita dificuldade, comunica aos fregueses, que tomam conhecimento da reimpressão do título bastante popular naquele momento e, ao procurá-lo, terão pouco risco de encontrá-lo esgotado, devido ao estoque reforçado disponível na banca.

É importante que se diga, no entanto, que nem sempre o relacionamento entre a Editora Abril e os donos de bancas de jornais esteve isenta de conflitos - ou ao menos da acusação sobre eles. No que se refere à circulação de periódicos da Editora, Genival Rabelo (1972, p. 43) aponta em artigo ao "Estado de São Paulo" a "[...] abusiva política de distribuição [...]" praticada pela Abril e denunciada pelo "Sindicato dos Jornaleiros de São Paulo", que consiste no esquema do "[...] ou tudo ou nada [...]": "[...] 'ou o jornaleiro compra todas as 35 publicações da Abril a maioria das quais deficitária e de difícil venda ou então não leva nada e não pode comprar as revistas de interesse de sua clientela'". Somava-se a isso, conforme Rabelo, o fato de a Editora transferir aos donos de bancas "[...] o ônus do financiamento das suas revistas (vende a vista e só recebe encalhes em limites preestabelecidos, com prazo de 90 dias até um ano para pagar segundo informação ao referido Sindicato)".

Não foi possível encontrar, em nossas pesquisas, nenhuma outra referência a este tipo de relação abusiva entre a Abril e os proprietários de bancas de jornais, 
nem informações sobre sua extensão também ao mercado de fascículos e livros colecionáveis. $\mathrm{O}$ artigo também não deixa claro se as condições eram as mesmas para jornaleiros de outros Estados e se foram impostas pela Distribuidora ou pela Editora (vale ressaltar que, embora sob a égide de uma mesma empresa, a Abril Cultural era uma divisão relativamente independente de sua irmã responsável pelos periódicos).

Em 1974, apenas quatro anos após o lançamento pioneiro de Papillon ${ }^{86}$, a compra de livros em capa dura e brochados (e não apenas os de bolso) já havia se tornado um hábito do grande público nas grandes cidades. Naquele momento, o país atingira o número de 15 mil bancas, sendo que, destas, 37\% localizavam-se nas cidades de São Paulo (3.000) e Rio de Janeiro (2.600) (CALDAS, 1974). A distribuição volta à pauta quando se observa que os volumes das coleções não eram comercializados simultaneamente em todos os Estados brasileiros. Os livros circulavam primeiro no Rio de Janeiro e em São Paulo, por serem locais de maior consumo e onde a Abril mantinha maior controle, para depois irem a outras praças, geralmente após dois meses, talvez aproveitando os volumes devolvidos pelas bancas, complementados com novas impressões, em caso de necessidade. Valêncio Xavier (1971) informa que, da tiragem inicial de 150 mil exemplares de Os Irmãos Karamazov, de Dostoiévski, 120 mil foram vendidos nos primeiros dias no eixo Rio-SP e os 30 mil remanescentes seriam distribuídos para o restante do país. A estratégia que se repetiu com Os Pensadores foi interrompida na edição de Teatro Vivo, que teve lançamento nacional, provavelmente para aproveitar o grande investimento em propaganda que foi realizado na produção, retransmitida para o restante do país, da peça teatral sobre a história do teatro.

86 Valêncio Xavier (1971) aponta que, na verdade, a primeira iniciativa de vendas de livros metodicamente em bancas de jornais (não se tratando dos de bolso) foi feita pelo "Sr. José Ghignone" em Curitiba. Há possibilidade de que as obras inaugurais de Dalton Trevisan tenham relação com o comércio de Ghignone, embora não tenhamos dados para confirmar este fato. A Livraria Ghignone, de propriedade de José, esteve intimamente envolvida com a geração curitibana de novos escritores contemporâneos a Trevisan. 


\subsection{Outras modalidades alternativas de circulação}

Antes de tratarmos de outros modelos de circulação fora do eixo das livrarias, alguns empregados pela Abril ou subsidiárias para suas publicações, convém pontuarmos que as coleções bibliográficas da Editora parecem ter sido também distribuídas em livrarias, principalmente nas regiões fora do eixo Rio-SP, ainda que este não fosse seu mercado preferencial. Há muito pouca informação acerca da relação entre a Abril e livrarias, principalmente pelo fato de os Civita utilizarem a própria máquina de distribuição de periódicos em bancas, que construíram ao longo dos primeiros 23 anos de atuação no Brasil, para venderem seus livros e outros produtos culturais, pelo que parece realmente ter sido apenas marginal o uso de livrarias ${ }^{87}$.

A comercialização de enciclopédias e dicionários por fascículos (ou capítulos) não foi introduzida no Brasil pela Abril. Ao menos cinquenta anos antes das coleções da Editora, estes livros, considerados de referência, eram vendidos através de assinaturas e remetidos aos compradores pelo sistema de entrega dos correios (RANGEL, 1974). A partir de 1934, a coleção em dez fascículos denominada "Galeria Nacional", cada um composto de cem "[...] retratos e biografias de vultos importantes da nossa história", foi anunciada ao preço de $2 \$ 000$ cada, mais 500 réis pelo volume a ser enviado por Correio ${ }^{88}$. Em 1938, a "Sociedade Propagadora da Cultura Mundial" anunciava o lançamento em fascículos semanais do "Grande Dicionário 'Lello Universal'”, cuja aquisição era feita por assinaturas no valor de $3 \$ 000$ cada fascículo, entregues na casa do assinante sem cobranças extras ${ }^{89}$. Esse modelo de vendas e distribuição caiu em desuso com a introdução dos fascículos em bancas (RANGEL, 1974).

87 Duas notas apresentadas no Correio Brasiliense (DF) e Diário de Pernambuco (PE) indicam que, ao menos nessas localidades, a coleção Os Imortais da Literatura Universal foi vendida também em livrarias. Disponíveis em: <http://memoria.bn.br/DocReader/029033 15/36855> e <http://memoria.bn.br/DocReader/028274 02/7172>. Acesso em 27 nov. 2017.

88 Disponível em: <http://memoria.bn.br/DocReader/030015 05/47427> e <http://memoria.bn.br/DocReader/030015_05/83385>. Acesso em: 27 nov. 2017.

89 Disponível em: <http://memoria.bn.br/DocReader/030015 05/86495>. Acesso em: 27 nov. 2017. 
Outra forma, ainda mais antiga que a anterior, é a venda de livros usados em lojas dedicadas a este tipo de comércio ou até em livrarias de especializadas em livros novos que também trabalhavam com usados. Conhecidas popularmente por "sebo"90 ou "alfarrábio", eram opções baratas para a compra de volumes de segunda mão e sua origem confunde-se com a das próprias livrarias de novos. Sendo tão tradicionais no Brasil, era previsível que as coleções da Abril, em algum momento, começassem a ser ofertadas nos alfarrábios do país. Mas alguns colecionadores foram bem rápidos, como o pernambucano que, apenas alguns meses após o término da publicação, anunciava nos classificados todos os 53 volumes de Os Imortais da Literatura Universa ${ }^{11}$. Em 1974, a Livraria São José, uma das mais tradicionais lojas de livros usados do Rio de Janeiro, publicou a venda "de ocasião" da coleção completa da enciclopédia em fascículos O Livro da Vida, lançado em 1971 e que, pela extensão da coleção, não há muito havia terminado de circular nas bancas.

Com relação às edições, a Abril, muito pela origem de seus proprietários, sempre foi uma empresa que olhou para fora do Brasil, especialmente para os países com setor editorial mais desenvolvido que o nosso, como Itália e Estados Unidos. O pensamento basilar era reproduzir, aqui, adaptado às necessidades locais, o que se fazia no estrangeiro. Se dava certo lá, aqui também tinha que dar. A venda ao consumidor feita por marketing direto, seja através de cupons em determinados veículos impressos ou mala direta, é um exemplo disso. O marketing direto é definido por Ike Zarmatti ([1980?]), diretor-gerente da "Divisão de Marketing Direto" da Editora, como a "[...] atividade de solicitar uma resposta diretamente a um público específico", isto é, sem intermediários:

\footnotetext{
O exemplo dentro da Abril é tipicamente a venda de coleções de livros [...] por mala direta, quando então são enviadas mensagens a um público previamente escolhido e este público responde diretamente à Abril, solicitando a compra desta coleção de livros [...].
}

90 A origem do nome "sebo", associado ao comércio de livros usados, é bastante controversa. A que nos parece mais crível é a história de que o famoso livreiro Pedro da Silva Quaresma, ao comprar a livraria de Serafim José Alves, iniciou a venda de apostilas importadas de Portugal, onde eram conhecidas como "sebentas", "[...] porque passavam de mão em mão, ano após ano, entre estudantes" (MASSON, 1971, p. 12), cujo produto emprestou o nome aos estabelecimentos que trabalham com livros usados.

91 Disponível em: <http://memoria.bn.br/docreader/029033 15/49024>. Acesso em: 27 nov. 2017. 
Para que o comércio baseado em marketing direto pudesse funcionar adequadamente, foi necessário aguardar a reestruturação dos Correios ${ }^{92}$, que melhoraram seu sistema e sua imagem perante o público, que deixou de recear a compra por encomenda postal, permitindo o acesso de consumidores residentes no interior e em regiões periféricas do país aos produtos que antes eram oferecidos apenas nos maiores centros urbanos.

Se os consumidores de São Paulo e Rio de Janeiro continuavam a ser o maior mercado, os do interior eram os que mais davam retorno ao sistema. Sergio Rangel Leite (LEITE, [1980?]) esclarece que cidades do interior possuíam uma população com bom poder aquisitivo, "[...] como os proprietários de terra, funcionários públicos, que têm poupança muito maior que a nossa [habitantes das grandes cidades], porque não têm nem onde gastar [...]" e a mala direta os propiciava "[...] comprar como se estivesse[m] em qualquer grande magazine", razão pela qual respondiam muito mais frequentemente às ofertas enviadas. Em vista disso, se o retorno dos cupons em São Paulo e no Rio estava na casa de 1 a 2 por cento, no interior "[...] chega a ultrapassar 50 por cento", um ótimo volume. A desvantagem do interior era ter menos nomes na lista que as capitais.

O marketing direto é um modelo de distribuição, "[...] na medida em que ele troca produto por dinheiro. Nesta aplicação, ele está exercendo função típica de um canal de vendas" (ARANHA, 1987). Este sistema desenvolveu-se como alternativa a outros modelos em meados da década de 1970 e a Abril começou a utilizá-lo em 1974, quando esse método de venda ainda era praticamente inexistente no Brasil. Por isso, apenas com o lançamento de Teatro Vivo, em 1976, consegue-se identificar uma ação de marketing direto para uma coleção de livros da Editora. A maior vantagem desta modalidade é a eliminação dos lojistas do ciclo e, por conseguinte, a melhora na margem de lucro.

92 Em março de 1969, o antigo e defasado DCT (Departamento de Correios e Telégrafos) foi convertido no atual ECT (Empresa de Correios e Telégrafos). Para mais informações sobre o processo de transformação do DCT em ECT, consultar VERGARA, Sylvia Constant; CAVALCANTI, Celso de Oliveira Bello. Do ECT à ECT: o resgate da virada na década de 70. RAP - Revista de Administração Pública, Rio de Janeiro, v.29, n.1, p.88-100, 1995. Disponível em: <http://bibliotecadigital.fgv.br/ojs/index.php/rap/article/view/8293/7068>. Acesso em: 02 dez. 2017. Para uma análise da história dos correios no Brasil, BARROS NETO, João Pinheiro. Administração pública: uma breve história dos correios. São Paulo: Annablume, 2004. 
Produzida pela Divisão de Marketing Direto da Abril, uma carta proposta com a oferta dos dez primeiros volumes da coleção foi oferecida a uma lista de clientes identificada como "preferenciais", por serem "pessoas especiais, cultas, ativas e com necessidade de publicações acima da média da população". O desconto sobre o preço de capa era irrisório, $\operatorname{Cr} \$ 5$ a menos que o valor dos dez exemplares comprados em banca, embora o risco inflacionário do período tornasse interessante a aquisição antecipada, de maneira que se evitasse que a coleção completa ficasse mais cara com o aumento no preço de volumes no decorrer da publicação. Além do panfleto informativo sobre a obra, duas cartas acompanhavam o pacote: uma com dados sobre os livros e sua importância e outra, assinada por Victor Civita, que além de apontar o trabalho de equipe e o tempo de pesquisa necessário para realizar o projeto, expõe sua paixão pelo teatro, definido como a arte que reúne as características das outras artes, "[...] propiciando uma experiência espiritual plena", para o qual a possibilidade de tomar "[...] consciência - individual ou social [...]" é o principal elemento do fascínio que desperta. A carta proposta foi enviada por mala direta para nomes que já constavam no cadastro de clientes da Editora, selecionados entre consumidores de outros produtos já editados e assinantes de revistas da empresa.

A "Divisão de Marketing Direto" foi criada em 1972, originalmente apenas para vender assinaturas de "Veja", transformando-se, posteriormente, em canal para distribuição de toda sorte de mercadorias. Ganhou tamanha importância que chegou a ter uma revista própria, a Caixa Postal Abril (Fig. Figura 60), um catálogo de produtos publicado trimestralmente e entregue gratuitamente aos clientes. 
Figura 60 - Revista Caixa Postal Abril

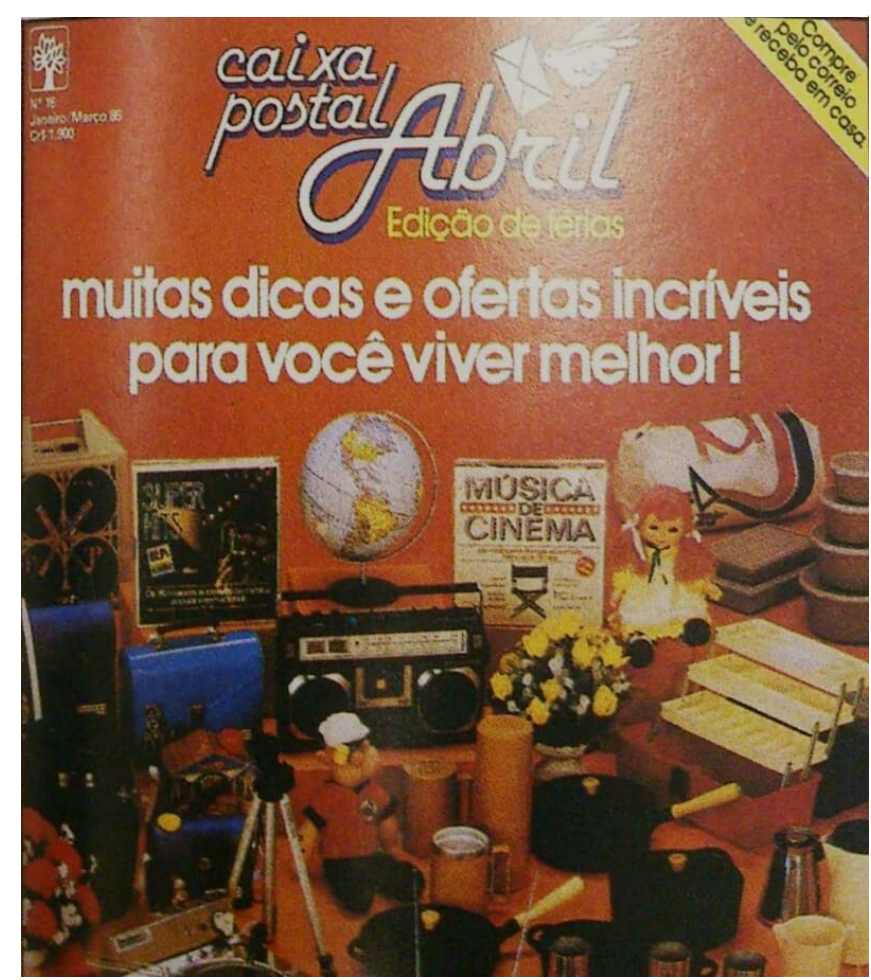

Fonte: MERCADANTE, Luiz Fernando. Victor Civita. São Paulo: Nova Cultural, 1987.

A Abril já havia realizado ações de marketing direto antes, desde as primeiras coleções, em especial as de menor porte, embora sem a importância que este sistema ganhou nos anos 1970. A modalidade básica para pagamento das coleções era o reembolso postal, ainda que também fossem executadas ações com pagamento direto, muitas vezes a partir de listas de empresas de cartão de crédito. $\mathrm{O}$ reembolso postal consiste na remessa do produto à agência do Correio mais próxima à residência do cliente, que efetua o pagamento, somado ao custo do serviço de envio, em alguns casos, no ato da retirada do pacote. O sistema garante certa segurança ao editor, por reduzir as perdas associadas aos repartes devolvidos de livrarias ou bancas, agiliza a prestação de contas e auxilia na interiorização do livro, conforme aponta Vieira (1975). O autor propunha que as editoras se reunissem para elaborar catálogos conjuntos de alguns de seus títulos, que deveriam ser distribuídos pelas agências da ECT, "[...] com indicações de como acionar o reembolso, a relação de todos os livros e revistas disponíveis, com endereço do 
editor, preço e prospecto do pedido", restando às editoras a realização de campanhas publicitárias de divulgação, que teriam o custo diluído se várias delas participassem. Não foi possível identificar se alguma ação do tipo foi executada durante aquele período.

Outra modalidade de distribuição de livros muito tradicional no Brasil é o clube do livro. Sua dinâmica consiste em reunir assinantes que, mediante pagamento periódico, recebem exemplares pré-selecionados ou selecionados com base em uma lista pré-determinada, dinâmica que permite a edição de obras com alta tiragem e venda garantida quando o clube reúne muitos clientes. Segundo Hallewell (2005), o "Clube do Livro", dirigido por Mário Graciotti, foi o primeiro de caráter "popular" no Brasil, em 1943. Anteriormente, existiram clubes menores, feitos por artistas brasileiros que editavam obras de luxo em baixíssima tiragem. Ainda na década de 1940, o "Livro do Mês" e o "Círculo Literário" apareceram adotando o mesmo sistema e, para um círculo restrito a militares, a "Biblioteca Militar", anteriormente "Biblioteca do Exército", surgiu em 1938. A "Coleção Saraiva”, que apareceu em 1944, em homenagem a Joaquim Inácio da Fonseca Saraiva, chegou a ter edições de 50 mil exemplares.

A Abril, ciente da potencialidade dos clubes do livro e vislumbrando um mercado com espaço a ser explorado, inaugura, em março de 1973, o seu "Círculo do Livro", empresa fundada em setembro do ano anterior em parceria com uma gigante do setor editorial alemão, a Bertelsmann, e limitado inicialmente à cidade de São Paulo. O "Círculo [...]" funcionava através da remessa bimestral de uma espécie de catálogo, a "Revista do Círculo", que oferecia livros divididos em seções, entre as quais cada sócio deveria optar por comprar ao menos Cr\$16 para se manter no clube, além da taxa mensal de $\operatorname{Cr} \$ 8$ e da inscrição única de $\operatorname{Cr} \$ 13$. Caso não escolhesse nenhuma obra, seria enviado o "Livro recomendado". As seções da primeira revista, com alguns títulos, eram:

1) "Livro recomendado": "O senhor embaixador", de Érico Veríssimo;

2) "Divulgação": "Eram os deuses astronautas?", de Erich von Daniken e "O macaco nu", de Desmond Morris; 
3) "Obras-Primas": "Oliver Twist", de Charles Dickens; "O retrato de Dorian Gray", de Oscar Wilde e "Ana Karênina", de Leon Tolstoi;

4) Livros Juvenis: "A ilha do tesouro", de Robert Louis Stevenson;

5) Documentos e Reportagens: "Treblinka", de Jean-François Steiner;

6) Romances de Ação: "Hospital", de Arthur Hailey e "Clarão na serra", de Francisco Marins;

7) Poesia e Teatro: "O diabo e o bom Deus", de Jean-Paul Sartre; e "Romeu e Julieta", de William Shakespeare.

Havia também as seções de biografias, romances históricos e "Retratos de Nossa Época". A cada bimestre, dez novos títulos estariam disponíveis. Os livros eram, em média, $20 \%$ mais baratos que nas livrarias: "Eram os deuses astronautas?”, por exemplo, custava $\operatorname{Cr} \$ 16$ nas livrarias e $\operatorname{Cr} \$ 12$ aos associados do "Círculo do Livro". O livro recomendado era sempre comercializado por um valor menor que o habitual e, após deixar essa categoria, tinha seu preço aumentado, uma estratégia que, apesar da boa variedade de opções da Revista, induzia o sócio à compra de determinados títulos. O recebimento e entrega dos pedidos era feito por uma equipe de vendedores independentes, que deveriam morar próximos ao associado e estarem dispostos a atendê-lo todos os dias da semana, incluindo domingos e feriados (A LEITURA, 1973). Em termos de materialidade gráfica, os volumes eram encadernados em capa dura, geralmente ilustrada, formato $13 \mathrm{~cm}$ por $21 \mathrm{~cm}$, com qualidade semelhante à impressão dos demais livros da Abril.

O sucesso do Círculo do Livro não demorou a chegar. No primeiro mês de atividade, associaram-se 1.412 pessoas. Em outubro de 1973, apenas sete meses após o lançamento, já formavam o "Círculo do Livro" 32.000 pessoas e, em janeiro de 1974, 45.000 sócios já recebiam bimestralmente a "Revista do Livro", ano em que a empresa participou, com um estande, da III Bienal Internacional do Livro de São Paulo. A escalada manteve-se e o número de sócios subiu para 100.000 em outubro do mesmo ano e atingiu 250.000 em novembro de 1975. Em fevereiro de 1977, meio milhão de leitores já recebiam edições do "Círculo [...]", "[...] o que o transformou no maior clube do gênero da América Latina, e numa das maiores editoras brasileiras de livros, com parque gráfico próprio e uma produção prevista para 1977 de 4 
milhões de exemplares". Naquele ano, já eram 1.551 revendedores ativos, que faziam 2,5 milhões de visitas, agora por trimestre, devido ao aumento do número de associados. Cada revendedor, por sua vez, realizava 5 visitas trimestralmente aos sócios (MEIO..., 1977, p. 97).

O "Círculo do Livro" já havia atingido, em 197593, patamar suficiente para colaborar, como acionista, da "Edibolso", empresa constituída em fevereiro daquele ano voltada à comercialização de livros de bolso em pontos alternativos. A Abril detinha $30 \%$ das ações ${ }^{94}$, e, além do "Círculo [...]", estavam associadas ao projeto a estadunidense Bentan Books, a DIFEL e a Record. A "Edibolso" foi a tentativa da Abril em extrapolar as bancas de jornais como pontos de venda para pocket books. Seus exemplares, que levavam em torno de 90 dias para serem publicados, entre o preparo do texto e a impressão ${ }^{95}$, eram disponibilizados ao preço máximo de $\operatorname{Cr} \$ 18$ em 1975. Além das bancas, estavam disponíveis em supermercados, postos de gasolina, farmácias, hotéis, lojas de departamentos e de discos e, posteriormente, também em livrarias, cinemas e aeroportos, sempre através de displays fornecidos pela empresa (Fig. Figura 61).

Apesar da ampla circulação, no início de 1978 as vendas estavam abaixo do esperado pelo estrelado elenco de acionistas, estacionadas na faixa de 100 mil livros ao mês, e "[...] com pouco menos de 6\% dos títulos de livros de bolso brasileiros, a Edibolso havia absorvido apenas 6,8\% do mercado" (HALLEWELL, 2005, p. 676). A insuficiência dos números explica o fato de a Abril ter utilizado, a partir de abril daquele ano, além dos canais mencionados, o reembolso postal para a comercialização dos volumes mais vendidos da "Edibolso", numerados de um a dez e divididos entre "ficção" e "não-ficção", tática que já indicava a tentativa por

93 No livro do professor Laurence Hallewell (2005), talvez por erro de digitação ou revisão, é indicado o ano de 1971 como sendo o de fundação da "Edibolso", mas todas as suas edições e notícias de lançamento apontam para o ano de 1975. Ainda, sendo o "Círculo do Livro" acionista com $14 \%$ da nova empresa, não poderia estar presente no quadro societário antes de 1973, quando foi fundado.

$9461 \%$, segundo Hallewell (2005).

95 Era possível realizar o processo em até dez dias, como foi o caso do livro-reportagem "Operação Resgate", de Alessandro Porro, de 120 páginas, escrito em duas semanas e publicado pela Edibolso, sobre "os soldados israelenses [que] invadiram o aeroporto de Entebbe, em Uganda, e resgataram os 105 reféns sequestrados por terroristas árabes num avião da Air France", em 1976. LIVRO instantâneo. Veja, São Paulo, 04 ago. 1976, p. 128. Disponível em: <http://acervo.veja.abril.com.br>. Acesso em: 10 dez. 2017. 
ampliar o mercado. Através do posicionamento das obras, era possível preencher o cartão-resposta e solicitar os livros. Ainda em 1978, na "V Bienal do Livro de São Paulo", um "dispositivo eletrônico" dava a chance de os frequentadores ganharem um livro da companhia ${ }^{96}$. Apesar dos 2500 pontos de vendas atingidos em $1978 \mathrm{e}$ das tentativas de sua diversificação e divulgação, a Edibolso teve suas atividades encerradas ${ }^{97}$, uma das raras apostas da Abril a fracassar na década de 1970.

Figura 61 - Display com livros da Edibolso

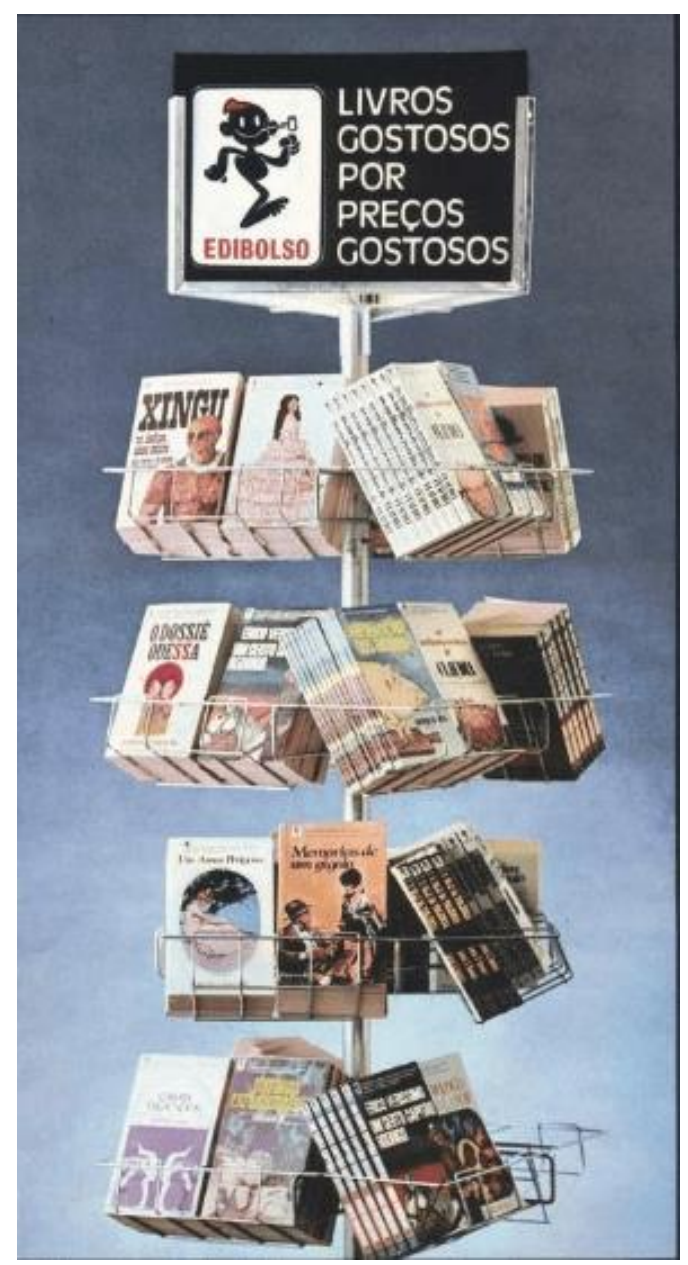

Fonte: Veja, 17 dez. 1975, p. 124. Disponível em: <acervo.veja.abril.com.br>.

96 TESTE do livro. Veja, São Paulo, 23 ago. 1978, p 98. Disponível em: <http://acervo.veja.abril.com.br>. Acesso em: 10 dez. 2017.

97 Conforme Hallewell (2005), a Edibolso foi posteriormente comprada pela Tecnoprint, embora não seja mencionada a data de aquisição. 
Acesso em: 05 dez. 2017.

Os racks como os empregados pela Edibolso eram comuns em editoras de livros de bolso. Mas, bem antes, a Editora Globo de Porto Alegre inovou ao utilizar uma estratégia de distribuição tão curiosa quanto única no Brasil. Henrique Bertaso, diretor da companhia, inspirou-se em uma ideia veiculada na "Publisher's Week", tradicional periódico estadunidense sobre o setor editorial, de empregar estantes para comercializar obras em livrarias de todo o país. O sistema funcionava da seguinte maneira, segundo informa José Otávio Bertaso (1993, p. 25-26), filho mais velho de Henrique: eram entregues aos livreiros, consignadas, "[...] uma ou duas estantes com prateleiras especiais para livros, trazendo no topo os dizeres 'Edições da Livraria do Globo'. Nessas estantes, encontrava-se uma amostra das publicações da Editora, que eram conferidas periodicamente (mensal, trimestral ou semestralmente) por um pracista, que anotava as vendas, as faturava e recebia o pagamento no ato, além de substituir os volumes faltantes por "novos lançamentos". Inicialmente implantado no Rio Grande do Sul, onde "[...] as estantes eram fabricadas na carpintaria da empresa e remetidas, junto com os livros, por via fluvial ou ferrovia" a todas as cidades gaúchas que estas vias alcançavam, o modelo foi expandido para o restante do país, em parceria com distribuidores e livrarias regionais. Em Salvador, Recife e Natal, Henrique Bertaso ainda realizou outra iniciativa incomum: trocou espaço publicitário nos jornais locais por "[...] artigos, crônicas e contos de autores então publicados pela Globo [...]", eliminando custos com propaganda.

Convém compreender, por fim, outro sistema muito utilizado pela Abril, já mencionado no capítulo 3, o "porta-a-porta". A Divisão de Volumes foi um departamento da Editora especializado em encadernar (ou reencadernar) fascículos e livros anteriormente publicados em bancas de jornais após o término das coleções, dando origem a novos produtos. Reunidos em coleções completas, eram comercializadas, através do "porta-a-porta", por 1.350 vendedores, que visitavam os domicílios e empresas oferecendo a oportunidade de compra à vista ou a prazo, através de crediário. Em 1972, nove mil coleções eram vendidas através desse sistema mensalmente (A INCESSANTE, 1972). 
Economicamente, a partir de 1974, a crise pós-“milagre", somada ao aumento do preço do papel, leva uma série de editoras brasileiras à falência ou concordata. Politicamente, a segunda metade dos anos 1970 é marcada pela distensão "lenta, gradativa e segura" promovida pelo penúltimo presidente militar do Brasil, Ernesto Geisel. A proposta de abertura do regime provocara no setor militar conhecido como "linha dura", por seu radicalismo e defesa de um regime ainda mais autoritário, a reação contra o projeto de abertura política. No começo da década seguinte, em abril de 1980, com o país já sob comando de João Baptista Figueiredo, o clima se acirra. Insatisfeitos com livrarias que exibiam em sua vitrine posters à venda de Ernesto Che Guevara, setores extremistas do governo, junto a membros reacionários do setor civil, como o C.C.C (Comando de Caça aos Comunistas), disparam, durante a noite do dia 4 e madrugada do dia 05 de abril, de acordo com Maués (2013), tiros contra três livrarias da cidade de São Paulo (livraria Editora Livramento, livraria Capitu e livraria Kairós). Seguem-se uma série de atentados contra outras livrarias, sedes de jornais, órgãos legislativos e de classe (OAB-RS). As bancas de jornais também foram vítimas de atentados, sendo bombardeadas e incendiadas aquelas que comercializavam periódicos da imprensa alternativa, de editoria considerada de esquerda.

Com o mercado diversificado, novas editoras concorrendo no segmento de coleções vendidas em bancas, como a Rio Gráfica, do conglomerado da TV Globo, e uma crise inflacionária que assustaria toda a população na década seguinte, a Editora Abril começou a perder o espaço e o domínio do setor que praticamente comandou sozinha durante década de 1970. Em 1982, a divisão da Abril em dois grupos, devido à separação dos irmãos Roberto e Richard Civita, pôs fim à Abril Cultural, que se tornou Nova Cultural. O cenário de então já era muito distinto daquele experimentado no lançamento de Papillon. Com valiosa contribuição da Abril, os livros populares para o mercado de massa já não estavam mais "à venda em todas as bancas" apenas, mas disponíveis em diversos outros canais e através vários outros métodos. 


\section{CONSIDERAÇÕES FINAIS}

Chegamos ao momento do estudo em que, após realizado todo o percurso investigativo, retomamos a pergunta inicialmente proposta: como foi possível realizar em nosso país, com as condições que apresentava, um projeto editorial de livros colecionáveis vendidos em bancas de forma tão bem-sucedida? Acreditamos que tenha sido elucidada a questão ao longo dos capítulos, nos quais procuramos demonstrar como uma série de elementos se coadunou de maneira a viabilizar o incrível volume de vendas apresentado pelas coleções. Esses elementos se reúnem em condições
a) Estruturais;
b) Materiais;
c) Discursivas;
d) Distributivas.

Cada uma contribuiu, reunida às demais, para o processo de comercialização em massa das coleções da Abril Cultural em bancas de jornais. Individualmente, não respondem pelo sucesso da Editora; apenas em conjunto dão origem a um sistema que propiciou e produziu o fenômeno, representado pelo fluxograma da figura Figura 62. A estrutura empresarial erigida pela Abril só foi possível, conforme identificamos no capítulo 2, devido ao momento histórico em que a empresa foi fundada, com baixo nível de concorrência e disponibilidade de recursos financeiros para que pudesse se constituir. Como um conglomerado, a Editora pôde contar, em meados da década de 1960, quando já estava há mais de dez anos atuando no país, com uma reserva de capital suficiente para investir na produção em altíssima tiragem de exemplares das coleções, bem como suportar uma propaganda extensiva e cara nos mais diversos veículos de massa. Os livros, materialmente muito bem-acabados e com capas decoradas, foram associados às necessidades subjetivas do públicoalvo. A associação entre materialidade e propaganda fomentou o interesse nas 
obras, que, por sua vez, dependeram da ampla rede de distribuição montada pela Abril para que pudessem efetivamente circular e atingir todos os objetivos comerciais planejados.

Figura 62 - Sistema de produção dos livros colecionáveis da Editora Abril

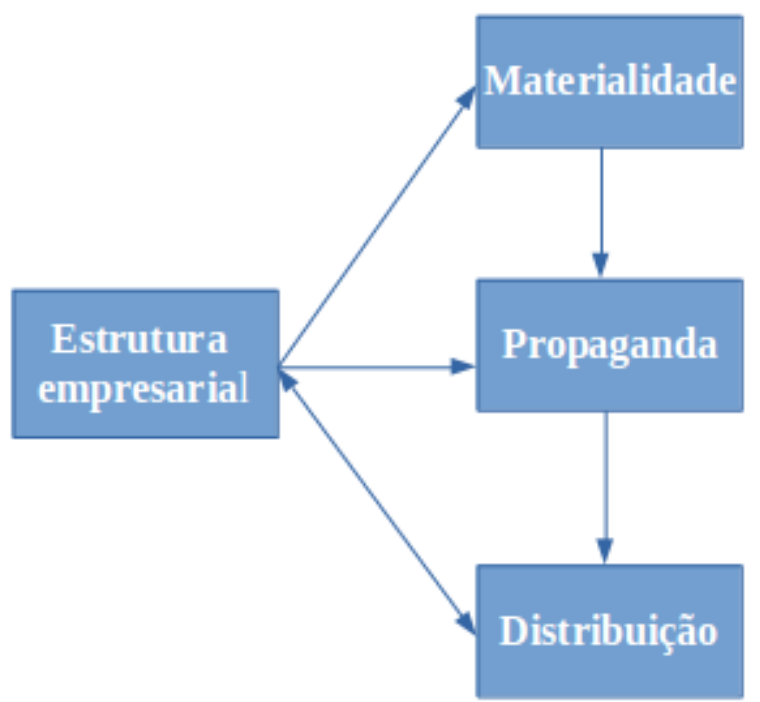

Fonte: Autoria própria.

O processo se inicia com Victor Civita, fundador da Editora Abril, que encontra, no final da década de 1940, quando a empresa é estabelecida, um cenário precário para a produção editorial. Muito antes dos incentivos oficiais ao desenvolvimento do setor, realiza, através de empréstimos internacionais, a importação de máquinas modernas para a instalação de um parque gráfico atualizado, eficiente e condizente ao seu ambicioso projeto empresarial. Dispondo de meios de produção, procura desenvolver também estratégias de distribuição e comércio até então inéditas no país, que lhe permitiram constituir a maior editora do país, com gráfica e distribuidora próprias.

Estabelecida a primeira condição, estrutural, e já com conhecimento suficiente do mercado editorial, começou o plano de vender não mais apenas revistas, mas também produtos culturais como fascículos, que se transformaram em coleções de bíblias e enciclopédias. Compreendeu, ainda, que precisava produzir exemplares com bom acabamento, que remetessem aos luxuosos volumes associados a obras 
de "alta cultura" pelos consumidores, o que o levou a imprimir e encadernar, a partir de 1970, livros com alto padrão gráfico em comparação aos demais vendidos no mercado de massa, superiores até às brochuras comercializadas em livrarias, condição material para que se sobressaíssem no mercado editorial. Percebeu a importância da propaganda, num período em que quase não eram utilizadas para divulgar livros, como ferramenta de convencimento e persuasão de um público não habituado à compra de obras de cunho erudito. Anunciou em intervalos de programas de rádio e TV, patrocinou peças e concertos, espalhou pela cidade suas coleções em outdoors e panfletos, além de imprimir em suas publicações atrativas peças proclamando as maravilhas de se comprar "cultura" e "conhecimento", em belos discursos que condicionaram uma parcela das classes médias a darem espaço, ao lado das geladeiras, enceradeiras, televisores e outros bens a esse produto chamado livro, como definiu Lobato.

Essa "massa" de interessados precisava encontrar com facilidade aqueles livros tão interessantes, e o eficiente sistema de distribuição em bancas de jornais, contando com agentes regionais que descentralizavam o processo de circulação, condicionou o encontro entre a oferta e a procura, que, com a garantia de rápido atendimento na reposição de estoques esgotados em todo o território nacional, tornou Platão, Dostoiévski e autores teatrais improváveis best-sellers. Ao controlar a edição, impressão e distribuição, a Abril pôde reduzir significativamente o valor cobrado pelos exemplares, o que, somado à grande tiragem, permitiu a oferta em bancas de jornais a valores baixos, por vezes inferiores a obras semelhantes vendidas em livrarias, ao mesmo tempo que mantinha uma boa margem de lucro para reinvestimento na empresa, reiniciando todo o processo, que se seguiu, coleção após coleção, a ponto de transformar a Abril Cultural de uma divisão da Editora Abril a empresa de maior faturamento dentro do conglomerado.

Quanto ao colecionismo de edições populares, não há dúvidas de que se disseminou a partir dos livros da Abril. Se antes a manutenção de livros abstraídos de sua utilidade imediatamente instrumental, que enceta questões de manipulação, ordem e classificação era voltada, no âmbito bibliográfico, principalmente aos colecionadores eruditos, Os Imortais da Literatura Universal, Os Pensadores, Teatro 
Vivo, entre outras publicações da Editora, demonstraram que a posse, acumulação e ostentação torna-os ferramentas de mediação simbólica para funções individualizantes de afirmação e diferenciação também entre o grande público. A esse aspecto, podem somar-se condições de fetiche pela forma, ainda que a coleção de artigos produzidos em massa não atenda a certas categorizações comuns entre os colecionadores, como os caráteres de unicidade e raridade (BAUDRILLARD, 2009).

O objeto de coleção, aquele retirado de sua função meramente utilitária, tem seu sentido completo a partir de sua relação com a coleção, com o todo. As partes, abstraídas do circuito funcional, perdem sua utilidade e tornam-se acúmulo. Sob a perspectiva dos leitores das edições publicadas pela Abril, nem todos eram, de fato, colecionadores. Parte do público adquiria o livro por seu caráter instrumental, como meio de comunicação de informações, literárias, técnicas, artísticas. Outro grupo de consumidores, ao possuir os objetos e retirá-los do circuito funcional, colecionavamnos. Havia, ainda, embora menos comum, o leitor que, adquirindo o livro por sua utilidade, após o uso deslocava-o ao campo dos objetos colecionáveis, que poderiam ser reconvertidos em sua funcionalidade instrumental. Este processo, peculiar, transforma cada exemplar da coleção em uma entidade flutuante entre a função e a posse.

O sucesso de vendas dos livros da Abril em praticamente todos os canais em que atuou demonstra que a descentralização do comércio bibliográfico, ainda que os Estados do Sul e Sudeste apresentassem a maior parte do público, era uma saída para o crescimento do mercado editorial brasileiro, assim como o rompimento da barreira ao acesso de livros por parte dos habitantes de cidades do interior do país e de regiões periféricas dos centros urbanos. Barker e Escarpit (1975), ao tratarem do problema europeu relativo ao hábito de leitura, apontam que "até data relativamente recente, o livro era considerado artigo quase que exclusivamente de luxo, ou pelo menos artigo de consumo destinado a uma minoria bem situada economicamente", veiculado exclusivamente através de livrarias, pertencentes a um círculo que exclui as massas. As bancas de jornais tiveram, dessa forma, um papel fundamental como descentralizadoras da distribuição e também do acesso ao livro. Em um momento 
em que se desenvolvia a incipiente indústria cultural no Brasil, as edições da Abril introduziram obras "quase que exclusivamente de luxo" nesse circuito dominado por produtos populares veiculados nos mais diversos canais de comunicação e circulação.

Ao mesmo tempo que pudemos observar a ampla disseminação bibliográfica, é difícil dimensionar os efeitos do acesso a livros de literatura, filosofia e teatro no grande público. Faltam dados, disponíveis no Departamento de Documentação da Editora Abril (DEDOC), para que se possa afirmar se, de fato, alguma fração dos colecionadores adquiriu o hábito da leitura regular ou, ao menos de aquisição de livros, através da compra de outras coleções ou mesmo da frequência a livrarias. Não sabemos se houve um efeito, ainda que superficial e temporário, de interesse por outro tipo de produção cultural que não a veiculada pelos canais de massa. Encontra-se problemas no texto, na diagramação e composição, mas nenhum nas capas. Havia fichas para reclamação quanto a problemas de encadernação, mas não para questões editoriais. Isso pode fazer crer que os livros de fato não eram para serem lidos, como já se dizia à época. Não é possível precisar. Sua materialidade "perfeita" ornamentou estantes nos mais diversos rincões do país, mas há referências a pesquisas, provavelmente arquivadas no DEDOC, que identificam a efetiva leitura das obras (o que, de fato, também não sugere verdadeira apropriação das mesmas).

Há no discurso "iluminista" do grande grupo que é a Abril, simbolizado pela figura de seu presidente, Victor Civita, o caráter mais de mediação do acesso do que da apropriação da cultura. A publicidade, em determinados momentos, faz crer que as coleções, ao introduzirem o beletrismo, a filosofia, a "alta cultura" em bancas espalhadas por todo o Brasil, possuiriam, por si, uma espécie de mecanismo civilizador e educativo, proporcionando aos leitores melhores oportunidades de posicionamento social e consecutivo implemento de renda, o que se alinhava à ideologia do Regime Civil-Militar (1964-1985) de ascensão pelo estudo e mérito pessoal, que se intensificaram a partir dos conceitos de "Brasil Grande" e "Nação Potência". O discurso desenvolvimentista dominante no período influenciou a opinião dos brasileiros durante o Regime a partir da perspectiva educacional, produzindo 
uma demanda por instrução que se associou ao desejo por distinção, fundado na necessidade de se estabelecer entre a camada social recém-adquirida. Essas condições foram contempladas pela aquisição dos exemplares e formação de coleções editadas pela Abril Cultural.

Ao romper com a ineficiência do mercado editorial em relação à impressão, distribuição e venda, além de adotar uma política agressiva de divulgação e um discurso de capitalização simbólica de suas edições, a Abril contribuiu para a introdução de um novo produto cultural no país, o fascículo, bem como para massificação do hábito de se consumir e colecionar livros. Também incentivou a melhora no padrão editorial dos exemplares vendidos fora do circuito das livrarias, através de um modelo de negócio que posteriormente seria adotado por editoras tradicionais. Já como grande conglomerado, ofereceu sua estrutura gráfica e distributiva para a produção e circulação de obras de outras casas publicadoras brasileiras.

O volume de vendas atingido pelas coleções da Abril é algo muito difícil de se repetir, por estar inserido em um contexto histórico, econômico e social muito particular que foi o Brasil da década de 1970. Apenas naquele decênio, "a Abril vendeu mais de 18 milhões de livros, em 465 títulos distribuídos em oito coleções" (PAIXÃO, 1997, p. 165). Mas suas estratégias de planejamento e divulgação deixaram heranças que ainda hoje se pode observar nas raras coleções que são postas à venda em bancas de jornais, voltadas principalmente às classes médias: volumes em capa dura, embora não mais mimetizando couro decorado, bom acabamento, alta tiragem e propaganda em diversos canais de divulgação.

O estudo do mercado editorial contemporâneo cresceu substancialmente nos últimos anos, quando a "História do Livro" passou a fazer parte de pesquisas nos campos da Comunicação, História, Ciência da Informação, entre outros. Notamos, porém, que em relação aos livros populares de massa e, especialmente, no que se refere à circulação desses produtos culturais através de canais alternativos de distribuição, muito ainda se tem a investigar. Esperamos ter oferecido nossa contribuição e podido despertar o interesse de nossos colegas nessa seara das 
obras de grande circulação, mas que ainda demandam e oferecem muitas possibilidades de novos estudos. 


\section{REFERÊNCIAS BIBLIOGRÁFICAS}

A ESTADA do Sr. Fiorello la Guardia em S. Paulo. O Estado de São Paulo, São Paulo, 03 fev. 1946. Disponível em: http://acervo.estadao.com.br. Acesso em: 27 jul. 2016.

A FUGA do inferno para a fama. Veja, São Paulo, n. 85, p. 3-6, 22 abr. 1970.

A GRANDE marcha. Veja, São Paulo, n. 220, p. 115, 22 nov. 1972.

A INCESSANTE criação de mercados. Expansão, São Paulo, 28 jun. 1972, p. 1621.

A LEITURA multiplicada. Veja, São Paulo, 14 mar. 1973, p. 85-86. Disponível em: <acervo.veja.abril.com.br>. Acesso em: 05 dez. 2017.

A REDESCOBERTA da emoção e da qualidade pela TV no Brasil. Jornal do Brasil, Rio de Janeiro, Caderno B, p. 12. Disponível em: <http://memoria.bn.br/DocReader/030015 09/139786>. Acesso em: 05 ago. 2017.

A SUPERESTRÉIA. Veja, São Paulo, n. 399, p. 120-121, 28 abr. 1976.

ABSURDO. Diário Carioca, Rio de Janeiro, 12 out. 1960, p. 6. Disponível em: <http://memoria.bn.br/docreader/093092_05/3542>. Acesso em: 20 nov. 2017.

ACERVO FOTOGRÁFICO INSTITUTO MOREIRA SALLES (IMS). Disponível em: $<$ http://fotografia.ims.com.br/>. Acesso em: 23 nov. 2017.

ADORNO, Theodor W.; HORKHEIMER, Max. Dialética do esclarecimento. Rio de Janeiro: Jorge Zahar, 1985.

ALMADA, Fernando. Publicidade e venda de livros. In: MAGALHÃES, Aluísio; HOUAISS, Antônio; SILVA, Benedicto et al. Editoração hoje. Rio de Janeiro: Ed. Fundação Getúlio Vargas, 1975.

AMARAL, Maria Adelaide. Com a peça "Bodas de Papel", nascia uma autora. Folha de São Paulo, São Paulo, 02 out. 2016. Disponível em: $<$ http://m.folha.uol.com.br/ilustrissima/2016/10/1818406-com-a-peca-bodas-depapel-nascia-uma-autora.shtml>. Acesso em: 25 jul. 2017.

AMARAL, Zózimo Barrozo do. Zózimo. Jornal do Brasil, Rio de Janeiro, Caderno B, p. $3, \quad 23 \quad$ abr. 1970 . Disponível em: <http://memoria.bn.br/DocReader/030015 09/6860>. Acesso em: 02 fev. 2017.

ANDRADE, Carlos Drummond de. Literatura, liquidação. Jornal do Brasil, Rio de Janeiro, Caderno B, p. 8, 20 ago. 1970. Disponível em: <http://memoria.bn.br/DocReader/030015 09/13564>. Acesso em: 19 fev. 2017. 
ANOS DOURADOS. Estante de livros: a Bíblia mais bela do mundo. 14 fev. 2015 . Disponível em: <http://www.anosdourados.blog.br/2015/02/estante-de-livros-bibliamais-bela-do.html>. Acesso em: 19 abr 2016.

APOSTA no futuro, Uma. Revista Veja, São Paulo, 23 mai. 1980, p. 4

APPADURAI, Arjun. A vida social das coisas: as mercadorias sob uma perspectiva cultural. Niterói: Editora da Universidade Federal Fluminense, 2008.

AQUINO, Cleber (Org.). História empresarial vivida: depoimentos de empresários brasileiros bem-sucedidos. São Paulo: Gazeta Mercantil, 1986. v. 4.

ARANHA, Eduardo de Souza. Suporte à força de vendas. Revista Administração de Empresas, v.27, n. 1, p. 57-61, jan./mar. 1987. Disponível em: <http://www.scielo.br/pdf/rae/v27n1/v27n1a08.pdf>. Acesso em: 04 dez. 2017.

ARQUIVO PÚBLICO DO ESTADO DE SÃO PAULO. DEOPS. DEOPS/SP. 50-E-332563, São Paulo, jan. 1978.

AVISOS. A Gazeta do Rio de Janeiro, Rio de Janeiro, p. 4, 24 jan. 1818.

AYALA, Walmir. As edições de arte: revisão 68. Jornal do Brasil, Rio de Janeiro, 08 jan. 1969, Caderno B, p. 2. Disponível em: <http://memoria.bn.br/DocReader/030015 08/127735> Acesso em: 19 set. 2016.

BAHIA, Benedito Juarez. Dicionário de jornalismo Juarez Bahia: século XX. Rio de Janeiro: Mauad X, 2015.

BARRETO, Junia. Traições editoriais: os trabalhadores do mar, de Victor Hugo a Machado de Assis. In.: Traduzires. Brasília, v. 1, n. 1, p. 84-94, 2012.

BAUDRILLARD, Jean. A Sociedade de Consumo. Lisboa: Edições 70, 2010.

BENJAMIN, Walter. A obra de arte na era de sua reprodutibilidade técnica. Obras escolhidas: Magia e técnica, arte e política. São Paulo: Brasiliense, 2012.

. Rua de Mão Única. In.: Obras Escolhidas II. São Paulo: Brasiliense, 1987.

BERNARDINI, Aurora Fornoni. Prefácio. In.: MANZONI, Alessandro. Os Noivos. São Paulo: Nova Alexandria, 2012.

BERTASO, José Otávio. A Globo da Rua da Praia. São Paulo: Globo, 1993.

BETTING, Joelmir. Notas econômicas. Folha de São Paulo, 14 jul. 1972, p. 25. Disponível em: <http://acervo.folha.uol.com.br>. Acesso em: 10 abr. 2017.

BOURDIEU, Pierre. A distinção: crítica social do julgamento. Porto Alegre: Zouk, 2011.

BRASIL. Constituição (1946). Constituição dos Estados Unidos do Brasil: promulgada em 18 de setembro de 1946. Disponível em: 
$<$ http://www.planalto.gov.br/ccivil 03/Constituicao/Constituicao46.htm>. Acesso em: 29 jan. 2016.

. Documentos de companhias. Diário Oficial da União. Rio de Janeiro, 06 abr. 1939. Seção 1, p. 55.

Sumário das decisões em reunião da Comissão da Tarifa, do dia 4 de novembro de 1948. Diário Oficial da União. Rio de Janeiro, 24 dez. 1948. Seção 1, p. 12.

. Lei no 4.680, de 18 de junho de 1965. Dispõe sôbre o exercício da profissão de Publicitário e de Agenciador de Propaganda e dá outras providências. Disponível em: <http://www.planalto.gov.br/ccivil 03/Leis/L4680.htm > Acesso em: 22 ago 2017.

Cartões de imigração. 1900-1965. Disponível em: <http://www.familysearch.org>. Acesso em: 15 mar. 2016.

BRINGHURST, Robert. The Elements of Typographic Style. Vancouver: Hartley \& Marks, 1996.

BURKE, Peter. História Social do Conhecimento: de Gutemberg a Diderot. Rio de. Janeiro: Jorge Zahar, 2003.

CABRAL, Eula Dantas Taveira. Internacionalização da mídia brasileira: análise das estratégias do Grupo Abril. In: Congresso Brasileiro de Ciências da Comunicação, 29., 2006, Brasília. Anais... Brasília, 2006.

CALDAS, Gracinha. Os livros saem das livrarias para as bancas. E Já vendem até 100 mil. Diário de Notícias, São Paulo, DN-Escolar, p. 25, 24-25 mar. 1974. Disponível em: <http://memoria.bn.br/docreader/093718 05/30831>. Acesso em: 28 ago. 2017.

CAMINHO da morte. Revista da Semana, 25 abr. 1909. p. 4. Disponível em: <http://memoria.bn.br/DocReader/025909 01/8879 >. Acesso em: 18 out. 2016.

CANO, Wilson. Raízes da concentração industrial em São Paulo. 1975. 335 f. Tese (Doutorado em Economia) - Instituto de Filosofia e Ciências Humanas, UNICAMP, Campinas. 1975.

CAROTTI, Carlo; ANDRIANI, Giacinto (Org.). La fabbri dei Fratelli Fabbri. Milão, Itália: FrancoAngeli, 2010.

CARTA, Mino. Carta ao leitor. In: Veja, São Paulo, p. 17, 08 de out. 1969. Disponível em: <https://acervo.veja.abril.com.br>. Acesso em: 07 mar. 2017.

CHAVES, Paulo Azevedo. Conselho. Diário de Pernambuco, Geral, p. 7, 12 set. 1976. Disponível em: <http://memoria.bn.br/DocReader/029033 15/89619>. Acesso em: 04 ago. 2017.

CIVITA, Roberto. A conquista de novos leitores pela Editora Abril. São Paulo, Revista Propaganda, fev. 1973. 
O planejamento e a comercialização de edições populares. In.: Centro Regional para o Fomento do Livro na América Latina; Instituto de Documentação da Fundação Getúlio Vargas; Sindicato Nacional dos Editores de Livros, 1975. Release. (Texto transcrito de fita gravada).

CIVITA, Victor. Resolvemos trabalhar para o ano de 1990. Realidade, São Paulo, fev. 1968, p. 107. Disponível em: <http://memoria.bn.br/docreader/213659/3672>. Acesso em: 15 jan. 2016.

CLEMENTE, Walter. A confiança no mercado editorial. Gazeta Mercantil, São Paulo, 25 abr. 1980.

COUTINHO, Ediberto. Papillon, a liberdade. Correio da Manhã, Rio de Janeiro, Anexo, p. 6, 24 abr. 1970. Disponível em: <http://memoria.bn.br/DocReader/089842 08/5434>. Acesso em: 02 fev. 2017.

DARNTON, Robert. O beijo de Lamourette: Mídia, cultura e Revolução. São Paulo: Companhia das Letras, 2010.

DAVALLON, J. A mediação: a comunicação em processo? Prisma - Revista de Ciência da Informação e da Comunicação, n. 4, p. 03-36, jun. 2007. Disponível em: <http://revistas.ua.pt/index.php/prismacom/article/viewFile/645/pdf>. Acesso em: 05 set. 2013.

DEPUTADO denuncia publicações à CPI. Correio da Manhã, Rio de Janeiro, 22 nov. 1963. p. 14. http://memoria.bn.br/docreader/089842_07/46123

DESSAUER, John P. Tudo sobre a publicação de livros: a experiência editorial nos Estados Unidos. São Paulo: Mosaico: EDUSP, 1979. 2v.

DIÁRIO DE NOTÍCIAS. 02 fev 1969, 1ª. Seção, p. 16. Disponível em: <http://memoria.bn.br/DocReader/093718 04/80933>. Acesso em: 18 nov. 2017.

DIAS, Haroldo. INL, a edição para baratear o livro. Jornal do Brasil, Rio de Janeiro, Livro (Suplemento do Jornal do Brasil), 25 set. 1971. Disponível em: <http://memoria.bn.br/DocReader/030015_09/40783>. Acesso em: 12 mar. 2017.

. INL, a edição para baratear o livro. Jornal do Brasil, Rio de Janeiro, Livro (Suplemento do Jornal do Brasil), 25 set. 1971. Disponível em: <http://memoria.bn.br/DocReader/030015 09/40783>. Acesso em: 12 mar. 2017.

DIEESE. Comparação das estruturas orçamentárias nas últimas décadas. Disponível em: <https://www.dieese.org.br/metodologia/pof3.xml>. Acesso em: 25 set. 2017.

DUALIB, Roberto. E a criação consolidou sua postura profissional. In.: Meio \& Mensagem Documento: Os Anos 70. São Paulo: Publicações Informativas Ltda., [1980?].

ECO, Umberto. Apocalípticos e integrados. São Paulo: Perspectiva, 2006. 
ELE escapou deste inferno. Revista Realidade, São Paulo, n. 49, p. 78-90, abr. 1970.

ELOGIO a Castelo quase deu cadeia. Correio da Manhã, Rio de Janeiro, 06 fev. 1965, p. 10. Disponivel em: <http://memoria.bn.br/docreader/089842 07/61778>. Acesso em: 27 jan. 2017.

ENTUSIASMO até o fim. Revista Veja, São Paulo, Memória, p. 76, 29 ago. 1990.

FARIA, Maria Isabel; PERICÃO, Maria da Graça. Dicionário do livro: da escrita ao livro eletrônico. São Paulo: Edusp, 2008.

FAUSTO, Boris. História concisa do Brasil. São Paulo: EDUSP, Imprensa Oficial do Estado de São Paulo, 2001.

FIGUEIREDO, Wilson. Segunda seção. Jornal do Brasil, Rio de Janeiro, 07 fev. 1965b, $1^{\circ}$. Caderno, p. 8.

. Segunda seção. Jornal do Brasil, Rio de Janeiro, 28 jan. 1965a, $1^{\circ}$. Caderno, p. 8. Disponível em: <http://memoria.bn.br/DocReader/030015 08/63858>. Acesso em: 28 jan. 2017.

FILÓSOFOS populares. Movimento. Opinião, Rio de Janeiro, 26 ago. 1974, p. 23. Disponível em: <http://memoria.bn.br/DocReader/123307/2095>. Acesso em: 12 mar. 2017.

FOLHA DA MANHÃ. São Paulo, 14 jul. 1950. Economia e Finanças, p. 8. Disponível em: <http://acervo.folha.uol.com.br/>. Acesso em: 29 abr. 2016.

$18 \quad$ jul. 1964, p. $16 . \quad$ Disponível em: <http://acervo.folha.uol.com.br/fsp/1964/07/18/2/>. Acesso em: 12 out. 2017.

. 15 jun. 1943, p. 3. Disponível em: <https://acervo.folha.com.br/index.do>. Acesso em 18 nov. 2017.

FONSECA, Edson Nery da. Grandezas e misérias da Indústria Cultural. Diário de Pernambuco, Recife, Primeiro Caderno, 25 jan. 1972, p. 4. Disponível em: <http://memoria.bn.br/DocReader/029033 15/23914>. Acesso em: 18 mar. 2017.

GASKELL, Philip. A new introduction to bibliography. New Castle: Oak Knoll Press, 2000.

GOMES, Pedro. Informe JB. Jornal do Brasil, Rio de Janeiro, 1․ Caderno, p. 10, 21 mai. 1965.

HALLEWELL, Laurence. O livro no Brasil: sua história. São Paulo: EDUSP, 2005.

HESSE, Paulo. Paulo Autran e Paulo Hesse. 2 mai 2015. Disponível em: <https://www.youtube.com/watch?v=PbikgepHf6M>. Acesso em: 02 ago 2017.

IBGE. Pesquisa Industrial Anual 1988-1995. Estatísticas do século XX. Rio de Janeiro: IBGE, 2007. 
IMORTAIS em massa. Vida Moderna. Veja, p. 68, São Paulo, 18 nov. 1970. Disponível em: <https://acervo.veja.abril.com.br>. Acesso em: 09 mar. 2017.

INCESSANTE Criação de Mercados, A. Revista Expansão, São Paulo, 28 jun. 1972.

INFORME JB. Jornal do Brasil, Rio de Janeiro, p. 10, 04 mar. 1967. http://memoria.bn.br/DocReader/030015 08/96549

JHALLY, Sut. The codes of advertising: fetishism and the political economy of meaning in the consumer society. New York ; London: Routledge, 1990.

JORGE, Salomão. A Editora Abril e a falsa promessa. O Estado de São Paulo, São Paulo, 05 jan. 1975, p. 54. Disponível em: <http://acervo.estadao.com.br>. Acesso em: 18 mar. 2017.

JORNAL DO BRASIL. n. 127, de 29 mai. 1926, p. 10. Disponível em: <http://memoria.bn.br/DocReader/030015 04/46813>. Acesso em: 09 nov. 2017.

Edição 2308, de 5 out 1934, p. 31. Disponível em: $<$ http://memoria.bn.br/DocReader/030015 05/47427> $<$ http://memoria.bn.br/DocReader/030015_05/83385>. Acesso em: 27 nov. 2017.

KONINGS, Johan. As traduções da Bíblia no Brasil. In.: GABEL, John; WHEELER, Charles. A Bíblia como literatura: uma introdução. São Paulo: Ed. Loyola, 2003.

LABANCA, Gabriel Costa. Dos anos dourados às Edições de Ouro: a Tecnoprint e o livro de bolso no Brasil (1930-1970). Dissertação de Mestrado. Rio de Janeiro: PPGH/Uerj, 2009.

LABARRE, Albert. História do livro. São Paulo: Cultrix, 1981.

LE GOFF, Jacques. História e memória. Campinas, SP: Editora da UNICAMP, 1990.

LEITE, Sergio Rangel. Graças aos Correios um negócio sério e de futuro. Meio \& Mensagem Documento: Os Anos 70, São Paulo: Publicações Informativas Ltda., [1980?], p. 165-168.

LIMA, Luiz da Costa. Comunicação e cultura de massa. In.: LIMA, Luiz da Costa. Teoria da Cultura de Massa. Rio de Janeiro: Paz e Terra, 1978.

LITERATURA e Sciencias. Correio Braziliense ou Armazém Literário. Londres, Inglaterra, p. 175, jul. 1817.

LITERATURA R. J. Diário Carioca, Rio de Janeiro, 24 mai. 1961, p. 6. Disponível em: <http://memoria.bn.br/docreader/093092 05/6182>. Acesso em: 20 nov. 2017.

LIVRARIA TRAÇA. Disponível em: <www.traca.com.br>. Acesso em: 21 nov. 2017. 
LIVROS para ler no lazer. Correio da Manhã, Rio de Janeiro, 16 mai. 1970, Anexo, p. 7. Disponível em: <http://memoria.bn.br/DocReader/089842 08/6524>. Acesso em: 15 fev. 2017.

LIVROS. Correio da Manhã, Rio de Janeiro, 18 jun. 1970, Anexo, p. 6. Disponível em: <http://memoria.bn.br/docreader/089842 08/8191>. Acesso em: 15 fev. 2017.

LOBATO, Monteiro. Prefácios e entrevistas. São Paulo: Brasiliense, 1955.

MAIA, Prestes. Estudo de um Plano de Avenidas para a cidade de São Paulo. São Paulo: Melhoramentos, 1930.

MAIS livros. In: Revista Veja, São Paulo, p. 17, 01 dez 1971.

MANGUEL, Alberto. Uma história da leitura. São Paulo: Companhia das Letras, 1997.

MARÃO, José Carlos. Uma aventura, a professorinha. Realidade, São Paulo, abr. 1970.

MARCUSE, Herbert. A ideologia da sociedade industrial. Rio de Janeiro: Jorge Zahar, 1979.

MARTIN-BARBERO, Jesús. Dos meios às mediações: comunicação, cultura e hegemonia. Rio de Janeiro: Editora UFRJ, 2009.

MASSON, Nonnato. Todo livro tem seu dia de sebo. Jornal do Brasil, Rio de Janeiro, 26 jun. 1971, Serviço, p. 12. Disponível em: <http://memoria.bn.br/docreader/030015 09/34947>. Acesso em: 29 nov. 2017.

MATOS, Mônica Moreira de. Clássicos comprometidos. Jornal do Brasil, Rio de Janeiro, 13 ago. 1979, Caderno B, p. 2.

MATOS, Odilon Nogueira de. A Cidade de São Paulo no século XIX. Revista de História, São Paulo, v. 10, n. 21-22, p. 89-125, 1955. Disponível em: <http://www.revistas.usp.br/revhistoria/issue/view/2982>. Acesso em: 05 fev. 2016.

MCKENZIE, D. F. Bibliography and the Sociology of Texts. Cambridge: Cambridge University Press, 1999.

MEIO milhão. Veja, São Paulo, 09 fev. 1977, p. 97. Disponível em: <acervo.veja.abril.com.br>. Acesso em: 05 dez. 2017.

MERCADANTE, Luiz Fernando. Victor Civita: biografia. Disponível em: $<$ http://grupoabril.com.br/pt/quem-somos/victor-civita/biografia>. Acesso em: 17 jan. 2016.

. Victor Civita. São Paulo: Nova Cultural, 1987.

MICELI, Sergio. A noite da madrinha e outros ensaios sobre o éter nacional. São Paulo: Companhia das Letras, 2005. 
Janeiro: IBGE, 2006.

MICHALSKI, Yan. Uma festa, com gesto e mensagem. Jornal do Brasil, Rio de Janeiro, 29 abr. 1976, Caderno B, p. 2.

MIRA, Maria Celeste. $O$ leitor e a banca de revistas: o caso da Editora Abril. Tese (Doutorado em Antropologia Social) - IFCH, Universidade Estadual de Campinas, Campinas, 1997.

MIRANDA, Tavares de. Reportagem. Folha de São Paulo, São Paulo, 05 fev. 1965, $2^{\circ}$. Caderno, p. 2.

MOLLIER, Jean-Yves. 0 camelô: figura emblemática da comunicação. São Paulo: Edusp, 2009.

MONT'ALEGRE, Omer. Por dentro do negócio. Jornal do Brasil, Rio de Janeiro, 11 dez. $1962,1^{\circ}$. Caderno, p. 9.

MOREIRA, Márcio. O fim da pura intuição e a chegada da técnica. In.: Meio \& Mensagem Documento: Os Anos 70. São Paulo: Publicações Informativas Ltda., [1980?].

NALCE, Ivo. Os bons nas bancas. Diário do Paraná, Curitiba, 08 out. 1972, Terceiro Caderno, p. 2. Disponível em: <http://memoria.bn.br/DocReader/761672/88867>. Acesso em: 24 nov. 2017.

NOGUEIRA, R. M. Marketing. Folha de São Paulo, São Paulo, 29 jul. 1964. $1^{\circ}$. Caderno, p. 6. Disponível em: <http://acervo.folha.uol.com.br/fsp/1964/07/29/2>. Acesso em: 12 out. 2017.

O HOMEM DE VENDAS DE 1965: VICTOR CIVITA. Revista Brasileira de Vendas, 57, dez. 1965.

O LIVRO sem livraria? Veja, São Paulo, 03 set. 1969, Brasil, p. 24-25. Disponível em: <acervo.veja.abril.com.br>. Acesso em: 22 nov. 2017.

O SÉCULO. n. 265, 26 jun. 1907, p. 3. Disponível em: $<$ http://memoria.bn.br/DocReader/224782/1047>. Acesso em: 09 nov. 2017

O SINTOMA dos salários. Veja, São Paulo, 17 dez. 1969. Brasil, p. 51. Disponível em: <https://acervo.veja.abril.com.br>. Acesso em: 26 set. 2017.

PAIXÃO, Fernando (Org.). Momentos do Livro no Brasil. São Paulo: Editora Ática, 1997.

PAPILLON, agora também no Brasil. Realidade, São Paulo, mai. 1970, p. 12. Disponível em: <http://memoria.bn.br/DocReader/213659/8815>. Acesso em: $15 \mathrm{fev}$. 2017. 
PASSOS, Maria Helena. A Bíblia confirmou a fé de Victor. Revista Leitura, São Paulo, set. 2003 [clipping DEDOC Abril não paginado].

PEREIRA, Mateus. H. F. A máquina da memória: o tempo presente entre a história e o jornalismo. Bauru, SP: EDUSC, 2009.

. A Trajetória da Abril Cultural (1968-1982). Em Questão, Porto

Alegre, v. 11, n. 1, p. 167-188, jan./jun. 2005. Disponível em: < http://seer.ufrgs.br/EmQuestao/article/view/120/78>. Acesso em: 04 set 2013.

PERISSÉ, Gabriel. Boccaccio e uma centena de histórias. In.: Revista Língua Portuguesa, São Paulo, n.11, p.48-51, set. 2006.

PIGNATARI, Décio. Informação, linguagem, comunicação. Cotia, SP: Ateliê Editorial, 2008.

POMIAN, Krzysztof. Colecção. In.: Enciclopédia Einaud. v. 1: Memória-História. Lisboa: Imprensa Nacional; Casa da Moeda, 1984. p. 51-86.

PORTA, Paula (Org.). História da Cidade de São Paulo, v. 1: a cidade colonial. São Paulo: Paz e Terra, 2004.

RABELO, Genival. Como não podia..., Tribuna da Imprensa, Rio de Janeiro, 31 jan. 1966, p. 8. http://memoria.bn.br/DocReader/154083_02/23435

O calcanhar de Aquiles de Victor Civita. Estado de São Paulo, São Paulo, 27 jul. 1972, Geral, p. 43. Disponível em: <http://acervo.estadao.com.br/>. Acesso em: 28 nov. 2017.

O capital estrangeiro na imprensa brasileira. Rio de Janeiro: Civilização Brasileira, 1966.

RANGEL, Maria Lúcia. Fascículos: a florescente indústria da cultura em fatias. Jornal do Brasil, Rio de Janeiro, 13 jul. 1974, Caderno B, p. 4-5. Disponível em: <http://memoria.bn.br/docreader/030015 09/107707>. Acesso em: 02 jul. 2017.

REBELLO, Gilson. O Rio de banca em banca: a história dos jornaleiros no Rio de Janeiro. Rio de Janeiro: O Dia, s. d.

REIMÃO, Sandra. Mercado editorial brasileiro: 1960-1990. São Paulo: Com-Arte: FAPESP, 1996.

REVISTA VEJA. n. 339, p. 44-45. Disponível em: <https://acervo.veja.abril.com.br>. Acesso em: 27 out. 2017.

ROTINA antiga. Jornal do Brasil, Rio de Janeiro, 14 mar. 1968. Disponível em: <http://memoria.bn.br/docreader/030015_08/112435>. Acesso em: 02 out. 2017.

SABADIN, Celso; PINHEIRO, Agnaldo ; GABRIELLI, Lourdes. Grupo Abril. In.: Os Grandes Conglomerados de Comunicação. Meio \& Mensagem Documento, 1982. 
SALLES, Mauro. Década de 70: a consolidação da propaganda. In.: Meio \& Mensagem Documento: Os Anos 70. São Paulo: Publicações Informativas Ltda., [1980?].

SÃO PAULO. Diário Oficial do Estado de São Paulo. Poder executivo. São Paulo, 04 jan. 1948. n. 3, p. 9.

S.A.I.B - Sociedade Anônima Impressora Brasileira. Diário Oficial do Estado de São Paulo. Poder executivo. São Paulo, 20 nov. 1950. p. 46.

SCARZANELLA, Eugenia. Entre dos exilios: cesare civita, un editor italiano en buenos aires, desde la guerra mundial hasta la dictadura militar (1941-1976). Revista de Indias, Madrid, Espanha, v, 69, n. 245, p. 65-94, 2009.

SEVERINO, Antônio Joaquim. Como ler um texto de filosofia. São Paulo: Paulus, 2009.

Educação, ideologia e contra-ideologia. São Paulo: Editora Pedagógica Universitária, 1986.

SILVA JUNIOR, Gonçalo. O homem Abril: Cláudio de Souza e a história da maior editora brasileira de revistas. Vinhedo, SP: Editoractiva Produções Artísticas, 2003.

SILVEIRA, Helena. Dois mil anos de teatro. Folha de São Paulo, 28 abr. 1976, llustrada, $\quad$ p. $36 . \quad$ Disponível $<$ http://acervo.folha.uol.com.br/fsp/1976/04/28/21//4283133>. Acesso em: 02 ago. 2017.

SINGER, Paul. Dominação e Desigualdade: estrutura de classe e repartição de renda no Brasil. Rio de Janeiro: Paz e Terra, 1981.

SKIDMORE, Thomas. Brasil: de Castelo a Tancredo. São Paulo: Paz e Terra, 1988.

SODRÉ, Nelson Werneck. História da Imprensa no Brasil. Rio de Janeiro: Mauad, 1999.

SPIVACOW, Boris. Memoria de un sueño argentino: entrevistas de Delia Maunás. Buenos Aires, Argentina: Ediciones Colihue, 1995.

STEINBERG, Charles S. Prefácio. In.: STEINBERG, Charles S. Meios de comunicação de massa. São Paulo: Editora Cultrix, 1970.

TOLEDO, Roberto Pompeu de. Victor Civita. São Paulo: Nova Cultural, 1987.

TSCHICHOLD, Jan. A forma do livro: ensaios sobre tipografia e estética do livro. Cotia, SP: Ateliê Editorial, 2007.

UM Bonde Chamado Desejo. In: Enciclopédia Itaú Cultural de Arte e Cultura Brasileiras. São Paulo: Itaú Cultural, 2017. Disponível em: <http://enciclopedia.itaucultural.org.br/evento398381/um-bonde-chamado-desejo>. Acesso em: 18 de ago. 2017. Verbete da Enciclopédia. 
UNIVERSIDADE FEDERAL DO RIO GRANDE DO SUL. Disponível em: $<$ http://www.ufrgs.br/faced/extensao/memoria/cartilhas imagens/alegria ler pre.htm $>$. Acesso em: 19 set 2016.

VEBLEN, Thorstein. Teoria da classe ociosa: um estudo econômico das instituições. São Paulo: Abril Cultural, 1983.

VENCEDORES e vencidos. A República: orgam do Partido Republicano. Curitiba, PR, p. 2, 06 ago. 1890. http://memoria.bn.br/DocReader/215554/1087

VERISSIMO, Erico. Um certo Henrique Bertaso. Porto Alegre: Globo, 1978.

VIEIRA, Roberto A. Amaral. Redução de custos gráfico-editoriais. In: MAGALHÃES, Aluísio et. al. Editoração hoje. Rio de Janeiro: Ed. Fundação Getúlio Vargas, 1975.

XAVIER, Valencio. Dostoiévski e números. Diário do Paraná, Curitiba, 14 fev. 1971. Terceiro Caderno, $\quad$ p. $6 . \quad$ Disponível <http://memoria.bn.br/docreader/761672/80514 >. Acesso em: 14 out. 2017.

ZAPPIENS. Disponível em: <http://www.zappiens.br>. Acesso em: 25 mar. 2015.

ZARMATTI, Ike. Marketing Direto: renascimento e consolidação. Meio \& Mensagem Documento: Os Anos 70, São Paulo: Publicações Informativas Ltda., [1980?], p. 161-164. 


\section{ANEXO I}

\section{Lista de títulos, ano de publicação, autores, tradutores e copyright da tradução da coleção Os Imortais da Literatura Universal}

\begin{tabular}{|c|c|c|c|c|c|}
\hline Número & $\begin{array}{c}\text { Ano de } \\
\text { Publicação }\end{array}$ & Título & Autor & Tradutor & Copyright da Tradução \\
\hline 01 & 1970 & Os Irmãos Karamazov & Fiódor M. Dostoiévski & $\begin{array}{c}\text { Natália Nunes e Oscar } \\
\text { Mendes }\end{array}$ & Cia. Aguilar Editora \\
\hline 02 & 1970 & As Aventuras do Sr. Pickwick & Charles Dickens & Octavio Mendes Cajado & Editora Globo S. A. de Porto Alegre \\
\hline 03 & 1970 & Madame Bovary & Gustave Flaubert & Araújo Nabuco & Livraria Martins Editora \\
\hline 04 & 1970 & Novelas Exemplares & Miguel de Cervantes Saavedra & $\begin{array}{c}\text { Darly Nicolana } \\
\text { Scornnaienchi }\end{array}$ & Editora Boa Leitura \\
\hline 05 & 1971 & Decamerão & Giovanni Boccaccio & Torrieri Guimarães & Hemus Livraria \\
\hline 06 & 1971 & Eugênia Grandet & Honoré de Balzac & Moacyr Werneck de Castro & Difusão Européia do Livro \\
\hline 07 & 1971 & Os Três Mosqueteiros & Alexandre Dumas, Pai & Octavio Mendes Cajado & Saraiva S. A. Livreiros Editores \\
\hline 08 & 1971 & Werther & Johann Wolfgang von Goethe & Galeão Coutinho & Livraria Martins Editora \\
\hline 09 & 1971 & Tom Jones & Henry Fielding & Octavio Mendes Cajado & Editora Globo S. A. de Porto Alegre \\
\hline 10 & 1971 & O Morro dos Ventos Uivantes & Emily Brontë & Oscar Mendes & Editora Globo S. A. de Porto Alegre \\
\hline
\end{tabular}




\begin{tabular}{|c|c|c|c|c|c|}
\hline \multicolumn{6}{|c|}{ Lista de títulos, ano de publicação, autores, tradutores e copyright da tradução da coleção Os Imortais da Literatura Universal } \\
\hline Número & $\begin{array}{c}\text { Ano de } \\
\text { Publicação }\end{array}$ & Título & Autor & Tradutor & Copyright da Tradução \\
\hline 11 & 1971 & Lorde Jim & Joseph Conrad & Mário Quintana & Editora Globo S. A. de Porto Alegre \\
\hline 12 & 1971 & A Vagabunda & Gabrielle S. Colette & Juracy Daisy Marchese & Difusão Européia do Livro \\
\hline 13 & 1971 & O Sol Também se Levanta & Ernest Hemingway & Berenice Xavier & Editora Civilização Brasileira S. A. \\
\hline 14 & 1971 & Pais e Filhos & Ivan Turguêniev & Ivan Emilianovitch & Livraria Martins Editora \\
\hline 15 & 1971 & $\begin{array}{c}\text { O Retrato do Artista Quando } \\
\text { Jovem }\end{array}$ & James Joyce & José Geraldo Vieira & Editora Civilização Brasileira S. A. \\
\hline 16 & 1971 & $\begin{array}{l}\text { Memórias Póstumas de Brás } \\
\text { Cubas / Dom Casmurro }\end{array}$ & Machado de Assis & - & - \\
\hline 17 & 1971 & $\begin{array}{c}\text { Tônio Kroeger / A Morte em } \\
\text { Veneza }\end{array}$ & Thomas Mann & Maria Deling & Boa Leitura Editora S. A. \\
\hline 18 & 1971 & Os Trabalhadores do Mar & Victor Hugo & Machado de Assis & Domínio Público \\
\hline 19 & 1971 & Servidão Humana & W. Somerset Maugham & Antônio Barata & Editora Globo S. A. de Porto Alegre \\
\hline 20 & 1971 & Ana Karênina & Leão Tolstói & João Gaspar Simões & Editora José Aguilar Ltda \\
\hline 21 & 1971 & Os Noivos & Alessandro Manzoni & Marina Guaspari & Editora Irmãos Pongetti \\
\hline
\end{tabular}




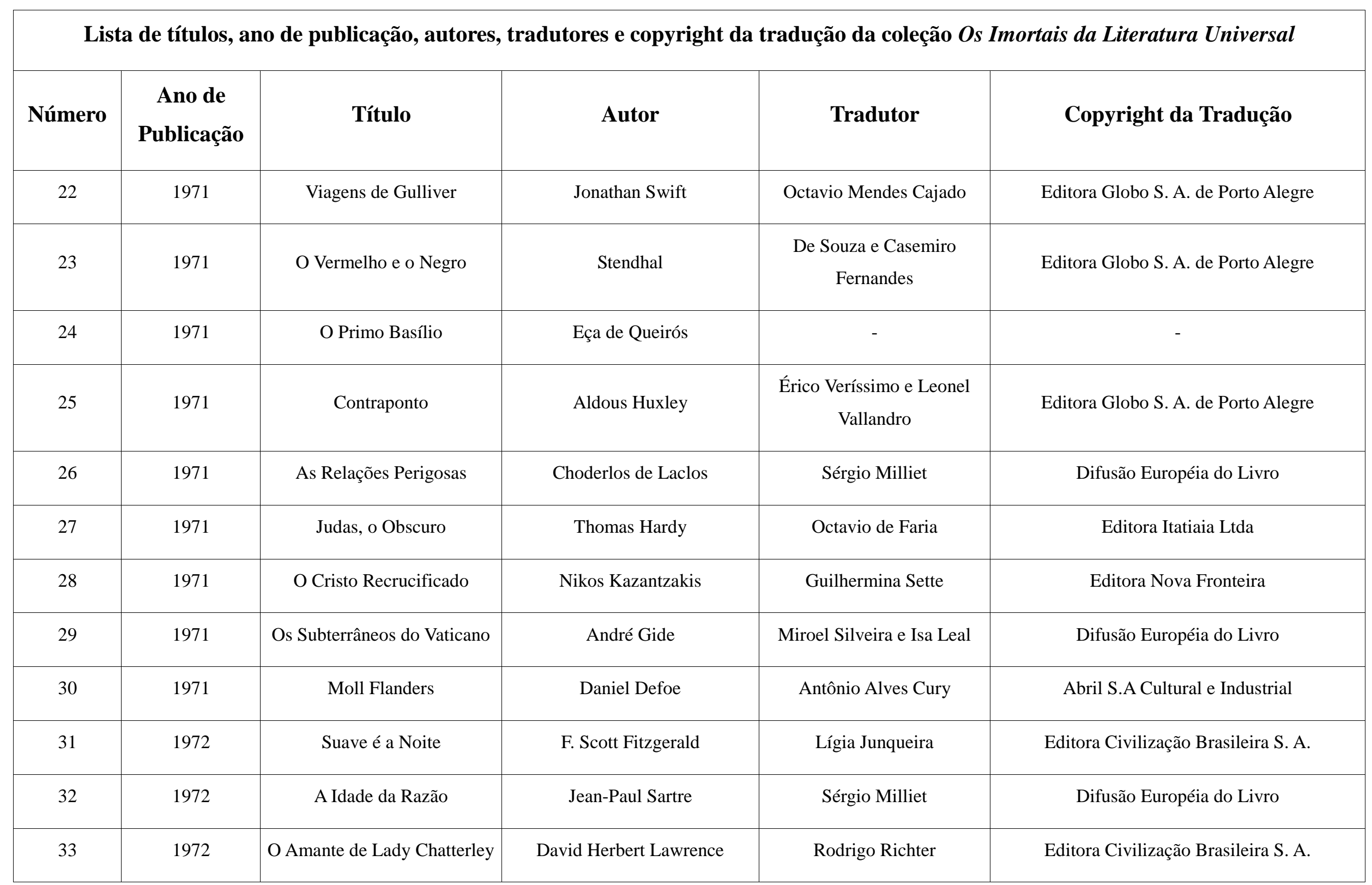




\begin{tabular}{|c|c|c|c|c|c|}
\hline \multicolumn{6}{|c|}{ Lista de títulos, ano de publicação, autores, tradutores e copyright da tradução da coleção Os Imortais da Literatura Universal } \\
\hline Número & $\begin{array}{c}\text { Ano de } \\
\text { Publicação }\end{array}$ & Título & Autor & Tradutor & Copyright da Tradução \\
\hline 34 & 1972 & As Vinhas da Ira & John Steinbeck & $\begin{array}{c}\text { Ernesto Vinhaes e Herbert } \\
\text { Caro }\end{array}$ & Editorial Bruguera Ltda \\
\hline 35 & 1972 & O Retrato de Dorian Gray & Oscar Wilde & Oscar Mendes & Editora José Aguilar Ltda \\
\hline 36 & 1972 & Germinal & Émile Zola & Francisco Bittencourt & Editorial Bruguera Ltda \\
\hline 37 & 1972 & Ivanhoé & Walter Scott & Brenno Silveira & Livraria Martins Editora \\
\hline 38 & 1972 & O Falecido Mattia Pascal & Luigi Pirandello & Mário da Silva & Editora Civilização Brasileira S. A. \\
\hline 39 & 1972 & $\begin{array}{l}\text { Lady Barberina / Outra Volta } \\
\text { do Parafuso }\end{array}$ & Henry James & $\begin{array}{l}\text { Leônidas Gontijo de } \\
\text { Carvalho / Brenno Silveira }\end{array}$ & Editora Civilização Brasileira S. A. \\
\hline 40 & 1972 & Contos & Voltaire & Mário Quintana & Editora Globo S A de Porto Alegre \\
\hline 41 & 1972 & Nosso Homem em Havana & Henry Graham Greene & Brenno Silveira & Editora Civilização Brasileira S. A. \\
\hline 42 & 1972 & Almas Mortas & N. V. Gógol & Tatiana Belinky & Abril S.A Cultural e Industrial \\
\hline 43 & 1972 & Moby Dick & Herman Melville & $\begin{array}{c}\text { Péricles Eugênio da Silva } \\
\text { Ramos }\end{array}$ & Abril S.A Cultural e Industrial \\
\hline 44 & 1972 & Babbit & Sinclair Lewis & Leonel Vallandro & Editorial Bruguera Ltda \\
\hline
\end{tabular}




\begin{tabular}{|c|c|c|c|c|c|}
\hline \multicolumn{5}{|c|}{ Lista de títulos, ano de publicação, autores, tradutores e copyright da tradução da coleção Os Imortais da Literatura Universal } \\
\hline Número & $\begin{array}{c}\text { Ano de } \\
\text { Publicação }\end{array}$ & Título & Autor & Tradutor & Copyright da Tradução \\
\hline 45 & 1972 & Mrs. Dalloway / Orlando & Virginia Woolf & Mário Quintana / Cecília \\
Meirelles & Editorial Bruguera Ltda \\
\hline 46 & 1972 & A Pele & Curzio Malaparte & Alexandre O'Neill & Editora Civilização Brasileira S. A. \\
\hline 47 & 1972 & A Romana & Alberto Moravia & Marina Colasanti & Editora Nova Fronteira \\
\hline 48 & 1972 & A Condição Humana & André Malraux & Jorge de Sena & Edição Livros do Brasil \\
\hline 49 & 1972 & O Estrangeiro & Albert Camus & Antônio Quadros & Edição Livros do Brasil \\
\hline 50 & 1972 & Ficções & Jorge Luis Borges & Carlos Nejar & Editora Globo S. A. de Porto Alegre \\
\hline
\end{tabular}

Obs: A esta lista de livros, acrescenta-se três volumes de biografias e bibliografias dos autores, formados a partir da encadernação dos fascículos que acompanhavam as obras.

Fonte: quadro elaborado pelo autor, com dados obtidos no DEDOC - Departamento de Documentação da Editora Abril. 


\section{ANEXO II}

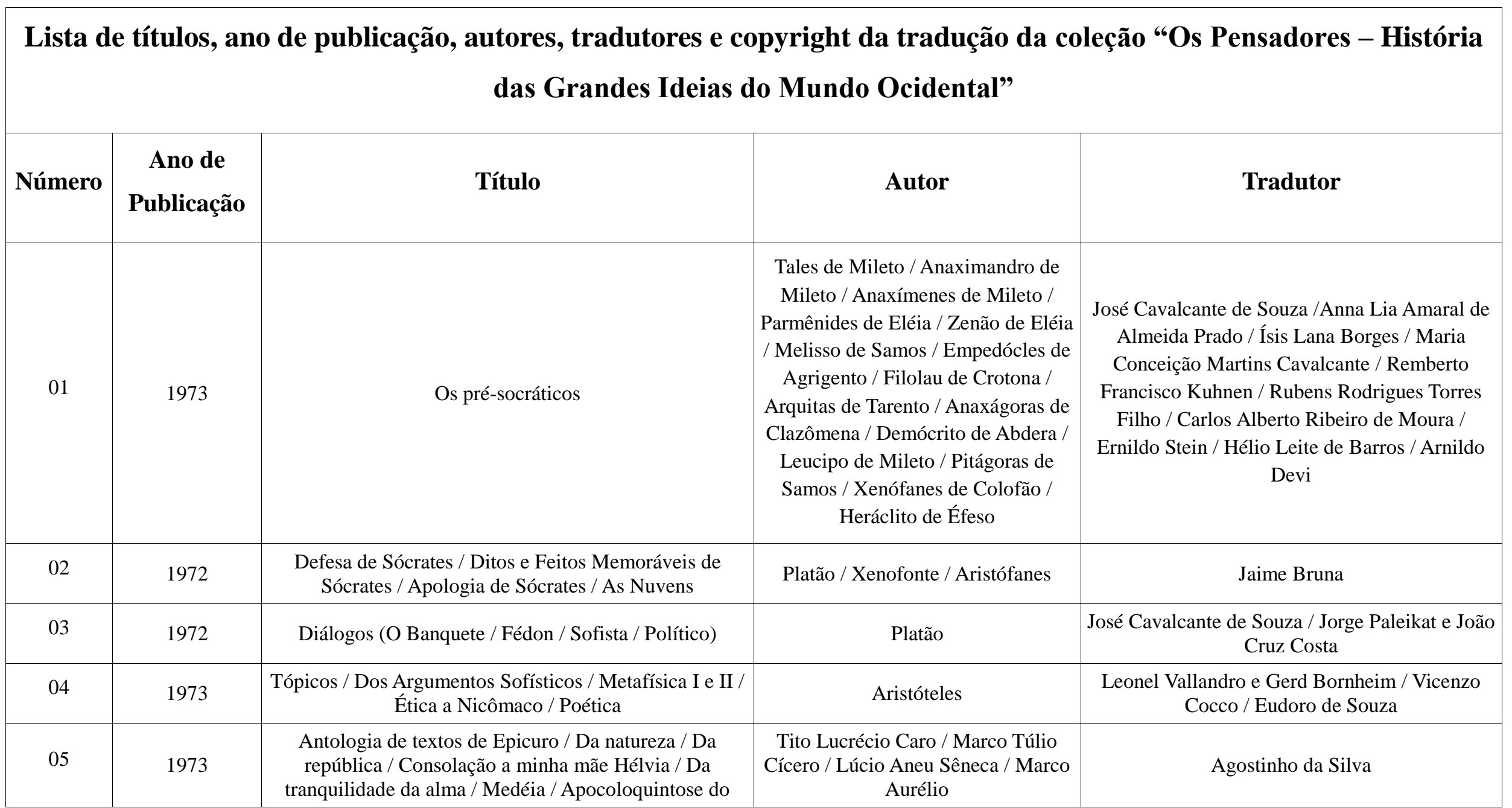




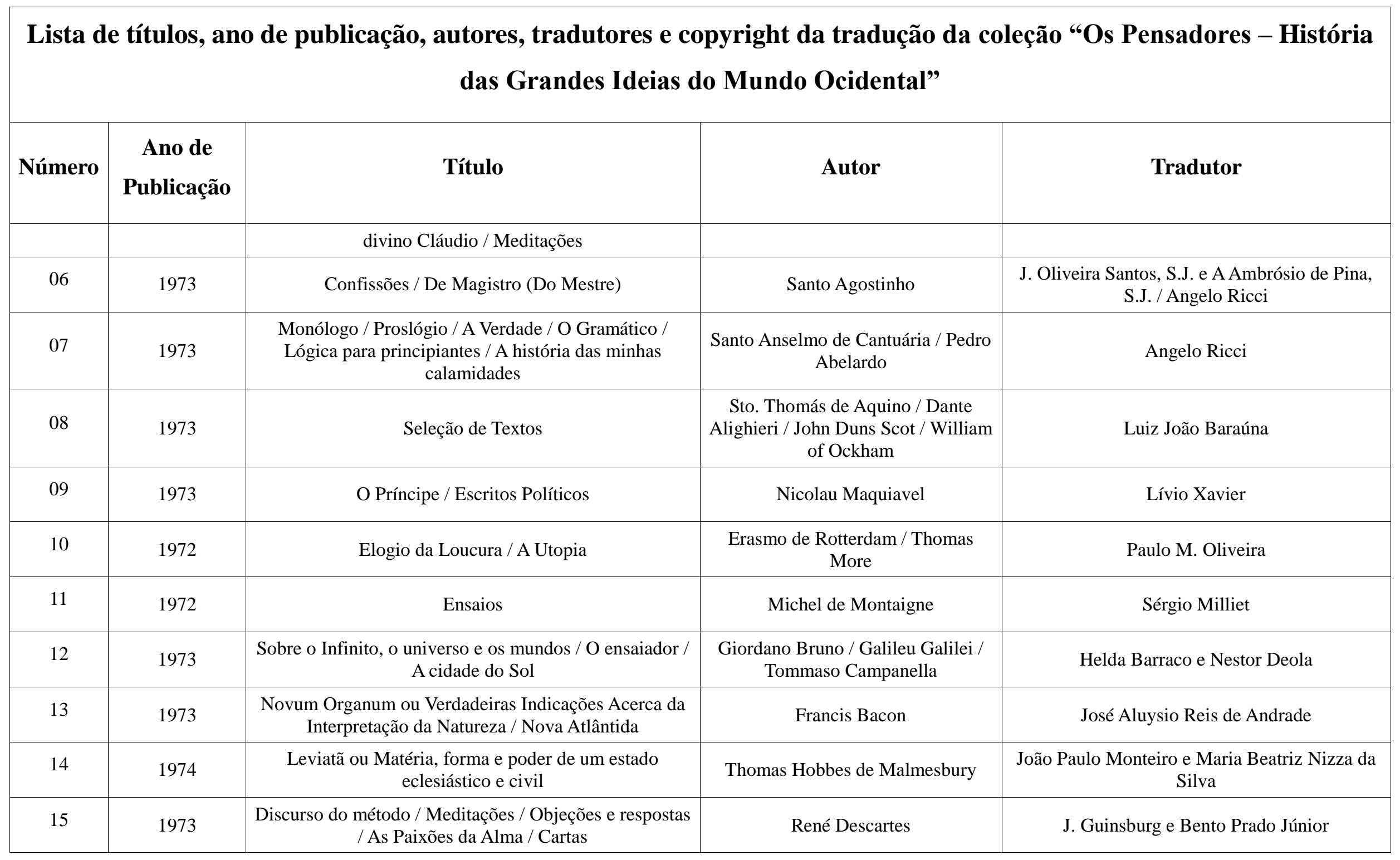




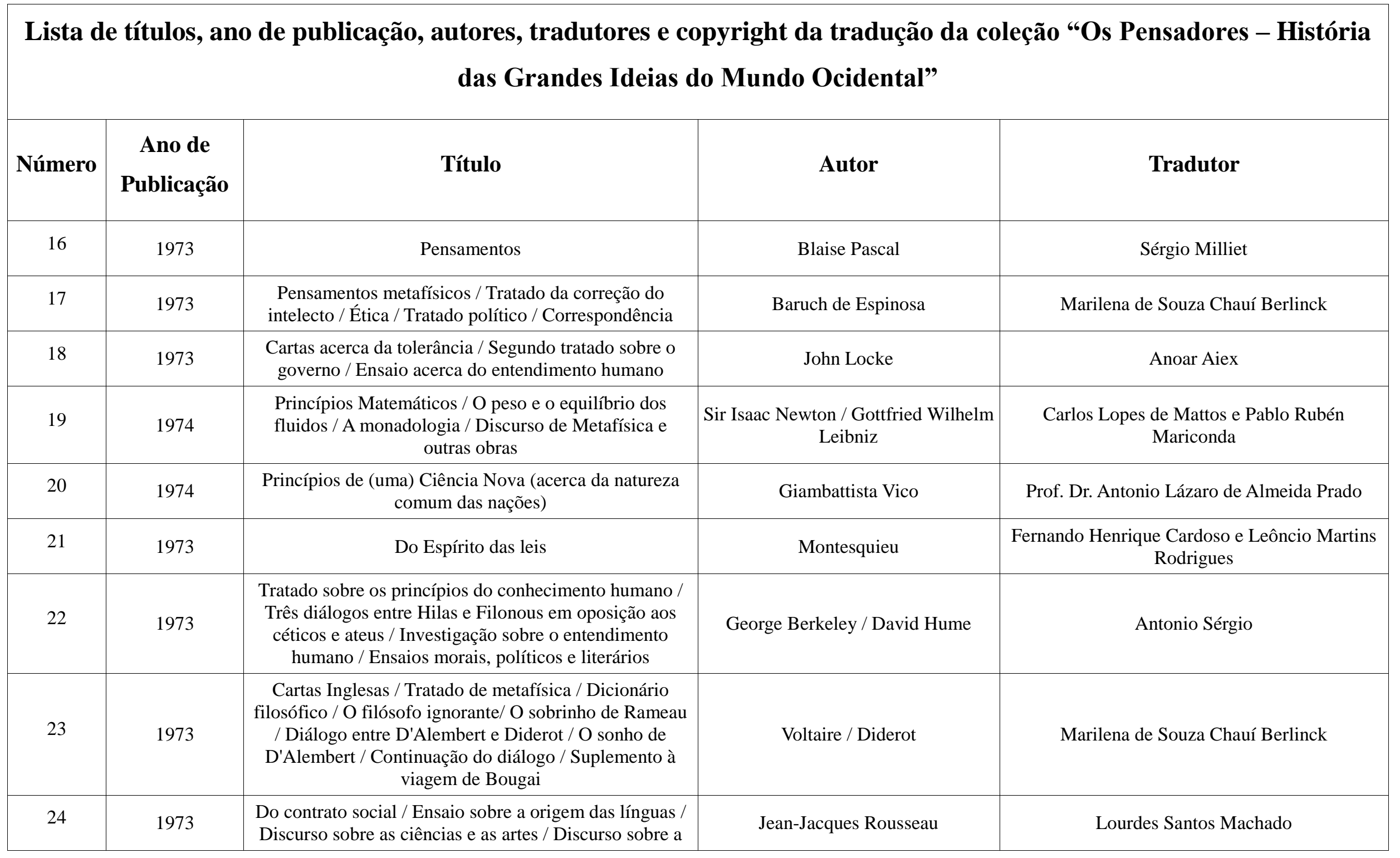




\begin{tabular}{|c|c|c|c|c|}
\hline \multicolumn{5}{|c|}{$\begin{array}{l}\text { Lista de títulos, ano de publicação, autores, tradutores e copyright da tradução da coleção "Os Pensadores - História } \\
\text { das Grandes Ideias do Mundo Ocidental" }\end{array}$} \\
\hline 25 & 1974 & Crítica da Razão pura e outros textos filosóficos & Immanuel Kant & Marilena de Souza Chauí Berlinck \\
\hline 26 & 1973 & Escritos filosóficos & $\begin{array}{l}\text { Johann Gottlieb Fichte / Friedrich } \\
\text { Von Schelling }\end{array}$ & Rubens Rodrigues Torres Filho \\
\hline 27 & 1973 & Texto escolhidos & Condillac / Helvétius / Degerando & Luiz Roberto Monzani \\
\hline 30 & 1974 & $\begin{array}{c}\text { A fenomenologia do espírito / Estética, a idéia e o ideal / } \\
\text { Estética, o belo artístico e o ideal / Introdução à história } \\
\text { da filosofia }\end{array}$ & Georg Wilhelm Friedrich Hegel & Henrique Cláudio de Lima Vaz \\
\hline 31 & 1974 & $\begin{array}{l}\text { Mundo como vontade e representação / Parerga e } \\
\text { Paralipomena / Diário de um sedutor / Temor e tremor }\end{array}$ & $\begin{array}{l}\text { Arthur Schopenhauer / Søren } \\
\text { Kierkegaard }\end{array}$ & $\begin{array}{l}\text { Wolfgang L. Maar / Adolfo C. Monteiro / Maria } \\
\text { J. Marinho / Carlos Grifo }\end{array}$ \\
\hline 32 & 1974 & Obras Incompletas & Friedrich Nietzsche & Rubens Rodrigues Torres Filho \\
\hline 33 & 1973 & $\begin{array}{l}\text { Curso de Filosofia Positiva / Discurso Sobre o Espírito } \\
\text { Positivo / Catecismo Positivista / As Regras do Método } \\
\text { Sociológico e Outros Textos }\end{array}$ & Auguste Comte e Émile Durkheim & Miguel Lemos \\
\hline
\end{tabular}




\begin{tabular}{|c|c|c|c|c|}
\hline \multicolumn{5}{|c|}{$\begin{array}{l}\text { Lista de títulos, ano de publicação, autores, tradutores e copyright da tradução da coleção "Os Pensadores - História } \\
\text { das Grandes Ideias do Mundo Ocidental" }\end{array}$} \\
\hline 35 & 1974 & $\begin{array}{l}\text { Manuscritos econômico-filosóficos e outros textos } \\
\text { escolhidos }\end{array}$ & Karl Marx & José Carlos Bruni \\
\hline 36 & 1974 & $\begin{array}{l}\text { Escritos Coligidos / Sobre a Justificação Científica de } \\
\text { uma Conceitografia / Os Fundamentos da Aritmética }\end{array}$ & $\begin{array}{l}\text { Charles Sanders Peirce e Gottlob } \\
\text { Frege }\end{array}$ & $\begin{array}{l}\text { Armando Mora D’Oliveira e Sérgio } \\
\text { Pomerangblum }\end{array}$ \\
\hline 37 & 1974 & Ensaios da Sociologia e Outros Escritos & Max Weber & Mauricio Tragtenberg \\
\hline 40 & 1974 & $\begin{array}{l}\text { Pragmatismo textos selecionados / Experiência e } \\
\text { Natureza textos selecionados / A Alemanha Imperial e a } \\
\text { Revolução Industrial / A teoria da classe ociosa }\end{array}$ & $\begin{array}{l}\text { William James, John Dewey, } \\
\text { Thorstein Veblen }\end{array}$ & Pablo Rubén Mariconda, Bolívar Lamounier \\
\hline 41 & 1975 & $\begin{array}{l}\text { Investigações Lógicas / Sexta Investigação (Elementos } \\
\text { de uma Elucidação Fenomenológica do Conhecimento) e } \\
\text { Textos Escolhidos }\end{array}$ & $\begin{array}{c}\text { Edmund Husserl e Maurice Merleau- } \\
\text { Pounty }\end{array}$ & Marilena de Souza Chauí Berlinek \\
\hline 42 & 1974 & Lógica e Conhecimento - Princípios Éticos & Bertrand Russell & Pablo Ruben Mariconda \\
\hline 43 & 1976 & $\begin{array}{l}\text { Argonautas do Pacífico Ocidental (Um Retrato do } \\
\text { Empreendimento e da Aventura dos Nativos nos } \\
\text { Arquipélagos da Nova Guiné Milanésia) }\end{array}$ & Bronislaw Malinowski & $\begin{array}{l}\text { Anton P. Carr e Ligia Aparecida Cardieri } \\
\text { Mendonça }\end{array}$ \\
\hline
\end{tabular}




\begin{tabular}{|c|c|c|c|c|}
\hline \multicolumn{5}{|c|}{$\begin{array}{l}\text { Lista de títulos, ano de publicação, autores, tradutores e copyright da tradução da coleção "Os Pensadores - História } \\
\text { das Grandes Ideias do Mundo Ocidental" }\end{array}$} \\
\hline 44 & 1975 & Coletânea de Textos & $\begin{array}{l}\text { Moritz Schlick, Rodolf Carnap e } \\
\text { Karl R. Popper }\end{array}$ & Luiz João Baraúna \\
\hline 45 & 1973 & $\begin{array}{l}\text { O Existencialismo é um Humanismo / A Imaginação / } \\
\text { Questão de Método / Conferências e escritos Filosóficos }\end{array}$ & Jean-Paul Sartre e Martin Heidegger & Vergólio Ferreira \\
\hline 46 & 1975 & Investigações Filosóficas & Ludwig Wittgenstein & José Carlos Bruni \\
\hline 47 & 1976 & Ensaios Econômicos & $\begin{array}{l}\text { J. M. Keynes, M. Kalecki, P. sraffa e } \\
\text { J. Robinson }\end{array}$ & Rolf Kuntz \\
\hline 50 & 1976 & Seleção de textos & Claude Lévi-Strauss & Chaim Samuel Katz e Eginardo Pires \\
\hline 51 & 1975 & $\begin{array}{l}\text { Contingências do Reforço / A Epistemologia Genética / } \\
\text { Sabedoria e Ilusões da Filosofia / Problemas de } \\
\text { Psicologia Genética }\end{array}$ & $\begin{array}{l}\text { Burrhus Frederic Skinner e Jean } \\
\text { Piaget }\end{array}$ & Bachel Moreno \\
\hline 52 & 1975 & Ensaios & $\begin{array}{l}\text { Gilbert Ryle, John Langshaw Austin, } \\
\text { Willard Van Orman Quine e Peter } \\
\text { Frederick Strawson }\end{array}$ & Balthazar Barbosa Filho \\
\hline
\end{tabular}

Obs. 1: O ano de publicação é o indicado nos exemplares, embora não corresponda ao ano em que as obras foram efetivamente lançadas. 
Obs. 2: A esta lista de livros, acrescenta-se quatro volumes de biografias e bibliografias dos autores, formados a partir da encadernação dos fascículos que acompanhavam as obras.

Fonte: quadro elaborado pelo autor, a partir de dados obtidos no DEDOC - Departamento de Documentação da Editora Abril, com correções e acréscimo da informação de tradutores para o volume 21 (Montesquieu) e ano de publicação e tradutores para o volume 31 (Arthur Schopenhauer/ Søren Kierkegaard). 


\section{ANEXO III}

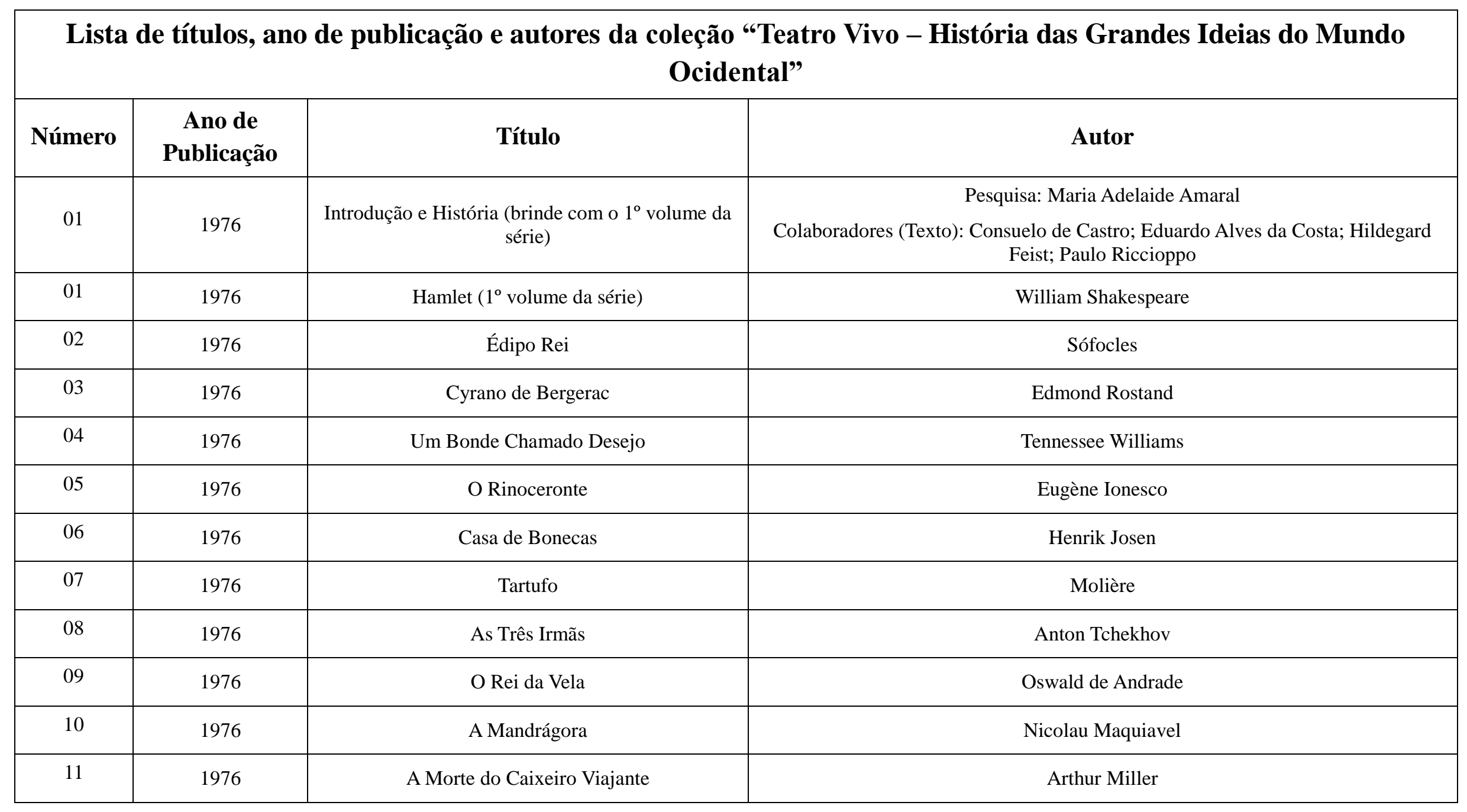




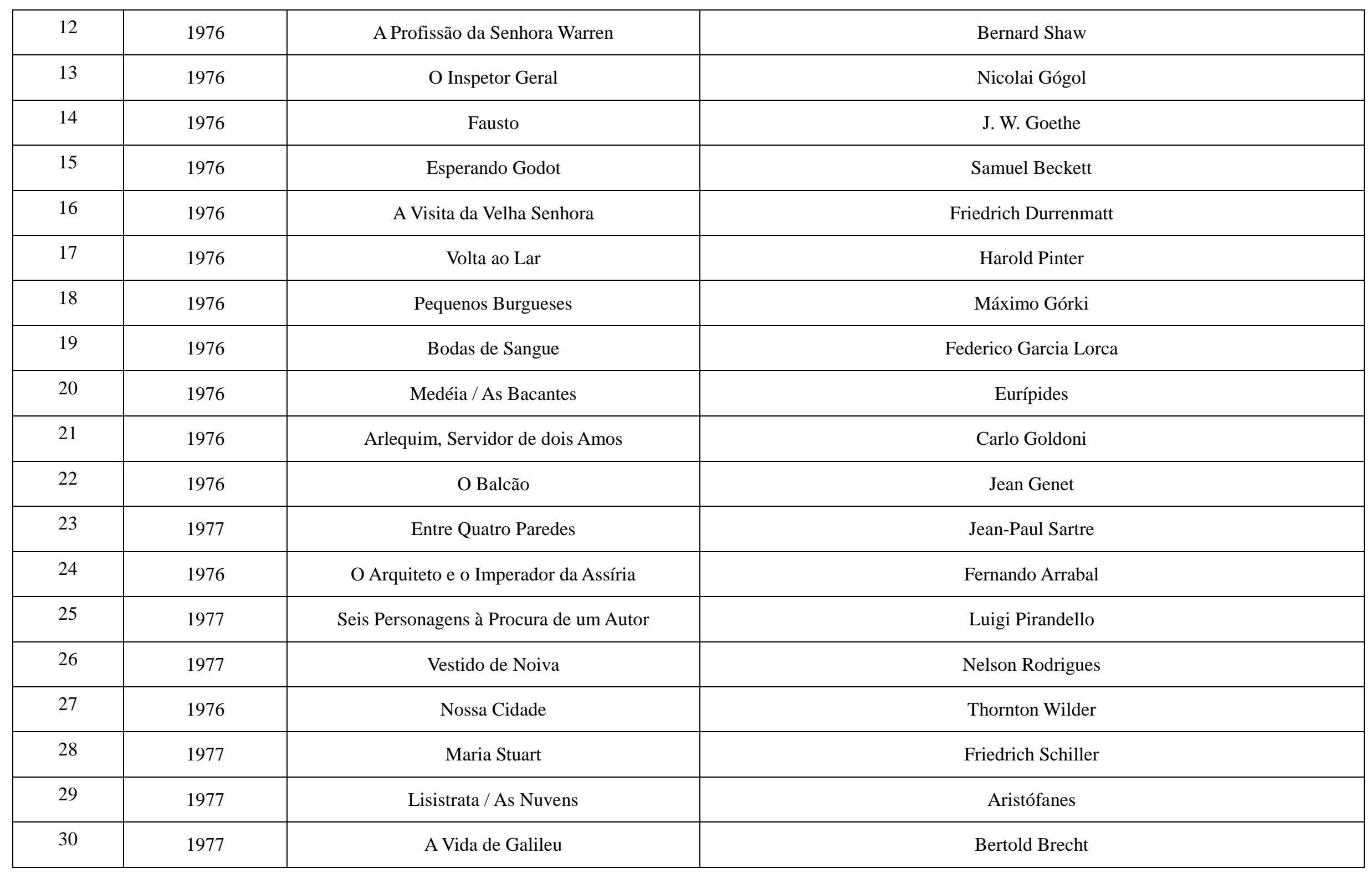




\begin{tabular}{|c|c|c|c|}
\hline 31 & 1977 & Marat / Sade & Peter Weiss \\
\hline 32 & 1977 & A Dança da Morte & Albert Camust Strindberg \\
\hline 33 & 1977 & Estado de Sítio & Edward Albee \\
\hline 34 & 1977 & Quem tem medo de Virginia Woolf? & Eugene O Neill \\
\hline 35 & 1977 & Longa Jornada Noite Adentro & \\
\hline
\end{tabular}

Fonte: quadro elaborado pelo autor, a partir de dados obtidos no DEDOC - Departamento de Documentação da Editora Abril. 


\begin{abstract}
ANEXO IV
Entrevista com Fernando Nuno, entre os meses de dezembro de 2017 e janeiro de 2018.

Fernando, como foi sua atuação da Abril Cultural durante a década de 1970 ? Quem eram os profissionais que trabalhavam na edição das coleções e como era selecionado o repertório de cada coleção?
\end{abstract}

Minha atuação na Abril Cultural, especificamente, foi bastante limitada, mas serviu de base sólida para o trabalho que desenvolvi no Círculo do Livro, em seguida. Darei a você um breve histórico de minha passagem por lá (foram 24 anos no grupo, do início de 1970 a abril de 1994). Espero que, dele, você possa extrair alguns tópicos para o seu trabalho. Entrei simultaneamente na ECA (somos colegas de faculdade em fases distintas, Wesley) e na Editora Abril. O 'vestibular' da Abril (416 candidatos para 4 vagas) foi até mais difícil que o da ECA! (2 mil para as cobiçadas cem vagas da manhã; a ECA oferecia outras cem à tarde).

Comecei como revisor, depois preparador de texto da Veja. Enquanto isso, o selo Abril Cultural iniciava sua, que me lembre, terceira coleção em bancas, Imortais da Literatura Universal (sendo as duas primeiras A Bíblia mais Bela do Mundo e Conhecer). O primeiro volume da coleção em que trabalhei foi o 20 (Ana Karênina), sob a supervisão de Boris Schnaiderman. Passei a dividir, aos 20 anos, a edição de texto dos livros com a cultíssima Maria de Fátima Mendonça Couto, a convite dela, pois o trabalho era demasiado para apenas uma pessoa.

Logo em seguida a Bertelsmann, que tinha os maiores clubes de livro do mundo, abriu no Brasil o Círculo do Livro, em parceria com o grupo Abril. A Bertelsmann entrou com o know-how e a gráfica e a Abril entrou com a equipe; assim, comecei como um faz-tudo editorial no Círculo, assumindo de vez o cargo de editor-geral do clube em 1977. O único funcionário enviado da Alemanha era o diretor da gráfica, montada nos moldes europeus pela Bertelsmann.

Antes disso, ainda fiz a edição de texto de outras coleções de livros da Abril Cultural (que me lembre, Clássicos Juvenis e, não estou certo do nome da outra, mas era algo como The Yellow Boys - uma série de policiais juvenis italianos.

Bom, vamos ao que importa para o teu trabalho. Que eu saiba, os principais responsáveis pelas coleções da sua pauta já morreram: o professor gaúcho Angelo Ricci, cassado por 1964, dirigia a coleção Imortais, e com ele aprendi muito. Os 
Pensadores era coordenada pelo professor José Américo Pessanha, um gênio também falecido precocemente; tive contato esparso com ele por conta do Círculo. Não lembro quem fez Teatro Vivo, mas Alberto Guzik (que depois trabalhou comigo no Círculo) estava lá. Como eu já tinha saído da Editora Abril na época das últimas duas coleções, não trabalhei nelas.

Você pergunta sobre a escolha do repertório. No caso de Imortais, a figura-chave foi o professor Ricci, com o apoio de professores-consultores. Para Os Pensadores, Pessanha foi o nome, trabalhando no mesmo sistema. Havia estudos de público, mas apenas como referência, não como norte. O marketing que se praticava então era bem diferente do de hoje. As coleções (como as editoras) tinham intenção e a função do marketing era levar o público a descobri-las e precisar delas; o marketing descobria e/ou criava o público para o livro. Por isso havia editoras comerciais tão específicas bem-sucedidas, em áreas de atuação bem diferentes: Zahar, Record, Civilização Brasileira, Pensamento sirvam de exemplo dessa diversidade. Hoje, o marketing, mais do que induzir o público a querer o que a editora propõe ou descobrir qual é esse público, ordena que a editora produza o que o público já quer. Com isso, as editoras vão ficando todas quase idênticas. Se uma faz 50 tons, a outra faz 50 tons e meio e a terceira inventa 51 tons, disputando um público já conquistado e gradualmente enfadado, em vez de ampliar os campos das necessidades culturais.

\section{Como era o processo de editoração dos livros em Os Imortais da Literatura Universal?}

O trabalho editorial dos volumes da coleção Imortais da Literatura Universal se processava em duas frentes. A edição se iniciava na Abril Cultural (na Rua do Curtume), e a segunda etapa era realizada na Editora Abril (então toda na Marginal Direita do Tietê, Av. Otaviano Alves de Lima). O contato direto entre as duas equipes era limitado, até por trabalharmos em endereços separados. Darei a você, Wesley, a descrição sucinta, os bastidores, desse processo.

$\mathrm{Na}$ Abril Cultural foi definida a coleção, foram contratados os direitos autorais das obras, foram redigidos os fascículos. Também lá era feita uma leitura prévia dos livros, a chamada edição de texto, para detecção de eventuais problemas da tradução contratada. A Editora Abril providenciava a preparação de texto (nome que se dá à normalização dos critérios de texto antes da diagramação e composição gráfica) e as revisões de provas tipográficas. Era uma época em que não se dava tanta atenção a creditar os nomes dos colaboradores de obras artísticas e literárias (vide a diferença nos créditos ao final dos filmes de cinema de então em relação com 
os de hoje, ou o fato de que discos como os dos Beatles, de Caetano, dos Stones etc. ainda não traziam os nomes dos músicos de apoio, por exemplo). Assim, o trabalho feito na Editora Abril não era creditado. Nem nós nos incomodávamos com isso.

Como a história começou para mim. Entrei na Abril e na USP em 1970. As baterias de testes da Abril foram mais árduas (416 candidatos para 4 vagas na editora, 2 mil vestibulandos para 200 vagas na ECA). Logo me destaquei e fui promovido a revisor e preparador de texto da Veja. Na revista, trabalhava dois dias por semana, sendo seis horas na quarta ou na quinta e de dezoito a 24 horas corridas na sexta (houve uma vez que o Kadáfi fez não lembro qual besteira na Líbia que o Mino Carta nos segurou por 27 horas direto).

Maria de Fátima Mendonça Couto, profissional experiente e excelente, era a preparadora de texto da Imortais. Formada em russo pela $\mathrm{FFLCH}$, as férias dela na Rússia caíram justamente no período em que devia ser preparado o volume Ana Karênina. No convívio com a equipe de preparação da editora, ela havia notado que eu já tinha certo conhecimento dos clássicos, por isso sugeriu à gerência que a substituísse. Como eu tinha tempo de sobra durante a semana, pude acumular esse trabalho, em freelancer, com o da Veja. A Fátima me passou o número do telefone do professor Bóris Schnaiderman (que havia sido orientador dela) e me pôs em contato com o professor Ricci (que dava as coordenadas da edição da Imortais na Abril Cultural, além de ter, pelo que entendi, escolhido com muita qualidade os volumes da série). O professor Bóris foi gentilíssimo. Só podia me atender aos sábados, e lá fui eu à casa dele por três ocasiões. Ele subia a escada de marinheiro que tinha na biblioteca doméstica para pegar os volumes russos no alto da estante. Eu pedia que ele me elucidasse pontos menos claros do texto, além de normalizar as grafias dos nomes russos pelo critério adotado na USP. Ainda não havia tradução direta do russo de Karênina. Bóris logo detectou que a tradução francesa em que se baseara a brasileira contratada pela Cultural tinha alterado os pontos de início e fim de vários capítulos do livro. Com a orientação dele, colocamos a edição brasileira de acordo com a original russa e várias falhas de tradução foram corrigidas. Não se falou em remuneração. Por isso, ao fim do trabalho, perguntei a Ricci se não seria possível pagar de alguma forma a disponibilidade de Bóris. Não havia verba. Pedi então que fosse colocado um agradecimento especial. Fiquei um pouco envergonhado com a tibieza do texto com que esse agradecimento foi publicado; porém, como disse, não era um tempo em que se creditassem com efusão os trabalhos de cultura.

O trabalho da Fátima Couto era sobrecarregado e não se limitava, segundo ela, à preparação, pois, ao que tudo indica, havia certa timidez na Abril Cultural quanto a mexer nos textos, um respeito excessivo talvez. Ana Karênina tinha sido mais um bom exemplo disso. Assim, ela pediu que a coleção passasse a ter dois preparadores: o segundo seria eu, tendo em vista o desempenho no volume de 
Tolstói. Assim, deixei a Veja e voltei a trabalhar cinco dias por semana, mas em algo que me satisfazia mais. A Biblioteca Mário de Andrade conta (ou contava) com salas especiais para estudiosos, onde se permite a entrada com livros trazidos de casa e onde se podiam pedir, para trabalho, quantos livros se quisesse, inclusive do setor de obras raras. (Se ainda é assim, e você não conhecia a possibilidade, pode ser talvez uma boa dica para você, Wesley.) Fátima, sabedora disso, requereu o uso de uma das salas. Lá, editamos em conjunto o texto dos volumes seguintes da coleção. Nosso método era: um de nós ia lendo a tradução em voz alta, enquanto o outro acompanhava a leitura no volume da língua original. E assim, creio, conseguimos resolver inúmeros problemas nas traduções contratadas. Depois de quatro volumes, como a situação de sobrecarga continuava, passamos a trabalhar individualmente, revezando-nos cada um de nós num diferente volume. Tendo-se chegado à conclusão de que a edição de texto estava na realidade sendo feita por nós, da preparação, por algum tempo a Abril Cultural abriu mão do cargo de editor de texto dos volumes. Fátima e eu fomos creditados pela edição nesse período. Três eventos marcantes que lembro agora: dei pela falta, na tradução, da introdução/explicação de Thomas Hardy a seu Judas, o obscuro. Traduzi esse texto e o inseri na edição. Também em outro volume, traduzido por importante escritor nosso, dei pela falta de um subcapítulo (de duas páginas apenas); ainda nesse caso fiz a tradução do trecho.

Apesar desses percalços, comuns na história da edição dos livros, gostaria de reafirmar a admiração pela bela escolha dos títulos da Imortais da Literatura Universal, feita, creio, pelo culto professor Ângelo Ricci. O aprendizado que tive ali me deu raízes para realizar mais tarde um dos trabalhos que mais me gratificou a alma: foi quando, a pedido da Publifolha, não só elaborei a lista da primeira coleção de clássicos da Folha de S. Paulo como também coordenei a edição da série e escrevi, além das orelhas de dezenove dos vinte volumes, textos especiais para os livros quando não havia algo assim nas traduções contratadas pela Publifolha (também nessa coleção detectei capítulos não traduzidos nas edições anteriores, que fiz traduzir e editei homogeneizando o texto para que as da Folha saíssem completas). A propósito, ainda, anos mais tarde meu filho Diego encontrou num site educacional o texto "O escritor dos humilhados e ofendidos" - que escrevi para o volume de Dostoiévski (Crime e castigo), da coleção da Folha -, devidamente creditado a mim (mas sem a minha autorização), apresentado pelo dito site como "professor da Universidade do Porto". Haja picaretagem na rede... Mas nunca mais encontrei esse site.

Após algum tempo, a Abril Cultural contratou novo editor de texto permanente para a coleção, um ex-padre, se lembro bem. O grupo Abril havia se juntado à alemã Bertelsmann para constituir o Círculo do Livro. A Bertelsmann forneceu o know-how e a Abril supriu o pessoal. Para as edições do texto, preferiu-se passar para 0 Círculo do Livro os preparadores da Editora Abril, pela qualificação que tinham: a 
Fátima Couto foi ser chefe de preparação e revisão do Círculo, preparadores exímios da Abril como Eliana Rocha, Silvana Salerno, Maria Lúcia Cardoso de Melo, Célia Regina Rodrigues de Lima do Rego Monteiro e Diego Mauro Emílio Calabi, entre outros, trabalharam nos primeiros lançamentos do Círculo, que foram principalmente clássicos da literatura. Eu também estava no time, como uma espécie de faz-tudo: além de preparação, fazia produção e diagramação, entrevistava e fotografava autores, traduzia obras e até operava a máquina de xerox: eu mesmo tirava as cópias dos textos que devia editar e preparar. Talvez por ser, na época, o mais novo, a mascote, tinha tanta disposição: e, provavelmente por causa dessa síndrome de hiperatividade (que felizmente venci anos depois), logo me deram o papel de editor do Círculo do Livro. Por dezessete anos, fiz o que hoje chamam de curadoria do Círculo, escolhendo (e tendo carta branca) todos os mais de 2 mil lançamentos da editora, com especial gosto pela criação de coleções.

Outra nota marginal a esta resposta a você, Wesley: em 1977, já no meu primeiro estágio num dos Círculos europeus da Bertelsmann, entrevistei, com a Silvana Salerno, minha mulher, o Eduardo Galeano, que estava para lançar As veias abertas da América Latina no Brasil. A entrevista deu as cinco páginas iniciais do caderno cultural da Folha de então, o "Folhetim"; entre o encontro com o Galeano e a publicação, porém, ainda fomos presos (por uma tarde) no DOPS, para onde fomos levados em camburões não identificados (no plural porque nos desencontramos na confusão e fomos presos separadamente) após uma manifestação contra a ditadura filmada pelo Gofredinho (filho da querida Lygia, que depois se tornou grande amiga nossa). Mas isso é outra história.

Enquanto isso, a Editora Abril passou o setor de preparação e revisão para a Abril Cultural, já num sistema industrial, de três turnos em 24 horas. Mas mesmo assim essa área de tratamento continuou a produzir grandes valores: o Pasquale Cipro Neto, por exemplo, fez parte da equipe três ou quatro anos depois de mim, já no âmbito da Nova Cultural. Pena que poucos anos depois desfizeram a equipe, e deixou de haver o treinamento intensivo que havia na Abril nessa área. $O$ tratamento de texto das coleções da Abril perdeu um bocado.

Uma outra curiosidade dessa trajetória que me ocorre agora, já que falamos em edição e revisão. Desde o início notei certa mágoa dos revisores, cujo trabalho consiste em corrigir textos muitas vezes ruins, mal redigidos. Apesar de serem muitas vezes mais cultos que os editores e redatores, os revisores nunca eram cotados para esses outros cargos. Revisores se consolam lembrando que Machado de Assis, Graciliano Ramos e José Saramago, entre tantos dos maiores escritores, foram também revisores. Por outro lado, é verdade que muitos excelentes revisores, mesmo quando têm essa queixa, têm grandes bloqueios para redigir bem. Eu fui um dos raros a cruzar a linha e, sendo sensível ao pleito, procurei aproveitar revisores quando precisava de um editor assistente no Círculo do Livro. A primeira pessoa que contratei dessa forma foi a Ibraíma Dafonte Tavares. Perguntei à Fátima Couto quem 
era o melhor revisor da equipe. Ela me indicou a lbraíma e eu, brincando, respondi: "Acabaste de perder tua melhor revisora". Hoje, tendo já passado por vários cargos de editor, a Ibraíma ministra, na Universidade do Livro, da Unesp, o principal curso de preparação e revisão do país. Outros editores que eu trouxe da revisão depois se tornaram figuras de destaque no mercado editorial: um foi diretor de marketing da Fnac, outra se tornou editora de infanto-juvenis da Melhoramentos.

\section{Você tem conhecimento de que "Os Noivos" foi publicado a partir de um resumo da obra original? Ainda, que "Os Trabalhadores do Mar" apresenta uma "troca" em seus capítulos?}

1) Sobre "Os Noivos", os diretores da coleção só se aperceberam de que a tradução contratada era um resumo numa fase em que não era mais possível reverter a publicação (havia um compromisso de data de lançamento assumido com o público leitor, por anúncio divulgado anteriormente) nem providenciar a tradução integral em tempo hábil.

2) OS TRABALHADORES DO MAR. Bem lembrado! É outro caso que eu já havia esquecido, Wesley. Esse foi publicado antes de ANA KARÊNINA (era um dos volumes imediatamente anteriores, número 16 ou 19, creio), portanto só deparei com o problema quando li o volume anos mais tarde (minha leitura doméstica não conseguia acompanhar o ritmo dos lançamentos da coleção, que eu vinha comprando, com desconto de funcionário, desde o número 1 na banquinha interna da Abril).

\section{Antes de trabalhar na Abril, você chegou a adquirir produtos da Editora? Como era o clima daqueles anos?}

No início da adolescência (anos 1960), via nas bancas a coleção TRÓPICO (uma enciclopédia temática não alfabética) e não conhecia ainda o nome 'fascículos'. Era como que uma revista 'diferente'. Até que em 1965 a Editora Abril lançou (creio que o selo Abril Cultural foi criado para a ocasião, você me confirma?) A BíBLIA MAIS BELA DO MUNDO. Quando chegou ao número 8, um anúncio de jornal de página inteira, com um texto enorme explicando a coleção (primeira tradução direta das línguas originais, a qualidade das imagens, a facilidade da encadernação, o preço acessível etc. - e, muito importante, todos os primeiros sete números anteriores 
estariam nas bancas (coisa inédita, pois banca não vendia números atrasados), e as bancas sempre teriam os três últimos fascículos (palavra nova para quase todos os leitores) à disposição, para o caso de perdermos algum lançamento. Fiz o meu pai ler o anúncio enorme inteiro (ele assinava a Folha e comprava o Estadão, então não sei em qual jornal foi, mas é provável que tenha sido nos dois e também em outros; havia muitos jornais diários). Não sei se ele teve a mesma vontade irresistível que eu, mas me parece que sim. Ele me deu o dinheiro, corri à banca, comprei os oitos fascículos e fiz a coleção até o fim. Se lembro bem, a própria Abril deu a lista dos encadernadores, que ficavam em inúmeros bairros.

Comecei então a comprar, avulsamente, a TRÓPICO, que lia como uma revista; ela já tinha passado do número 100 e não parecia ter fim definido. Saiu também a Tecnirama, por outra editora, e também comprei vários fascículos dela. Em 1966 a Abril Cultural lançou CONHECER, na mesma linha da TRÓPICO mas com visual mais moderno, traduzida e adaptada do italiano. Estava instalada a febre dos fascículos entre a classe média. Também colecionei e encadernei a CONHECER inteira. A TRÓPICO se extinguiu naturalmente. Não comprei mais a TECNIRAMA. Vieram outras séries da Abril: dessa fase inicial, colecionei GÊNIOS DA PINTURA, ARTE NOS SÉCULOS (que comprava com desconto de funcionário na banquinha interna da Abril). Em 1969, ano anterior a minha entrada na ECA e na Abril, vários jovens colegas do colegial e amigos do bairro (Santana) colecionavam, como eu, os fascículos com mini elepês de GRANDES COMPOSITORES DA MÚSICA UNIVERSAL. Imagine jovens de 16, 17 anos conversando e discutindo Bach, Beethoven, Mozart... Éramos nós. Curtir Beatles, George Martin, Rogério Duprat e Mutantes (além de Gil e Caetano) entrava no pacote. A febre era tão grande que quando saiu a série IMORTAIS DA LITERATURA UNIVERSAL, de que tratamos no início da nossa conversa, na Abril se espalhou que estava sendo necessário reimprimir o número 1, OS IRMÃOS KARAMÁZOV, que havia se esgotado, tendo vendido 300 mil exemplares. Hoje o número me parece exagerado.

$E$, para dar ideia do clima entre os jovens da época, sonhadores de um mundo novo (sobre o qual Paul McCartney disse há poucos anos, numa entrevista à Veja: nem parece que os anos 60 existiram, tudo voltou a ser como era antes), conto a você um episódio profissional-pessoal. Quando João Noro, o primeiro diretor editorial do Círculo do Livro, me convidou a ser o editor da casa, respondi que o cargo devia ser da Fátima Couto (então chefe de revisão do Círculo), ela que me havia ensinado tudo o que eu sabia sobre o trabalho de edição e seria falta de ética eu passar por cima dela. O Noro me disse: Então vá falar com a Fátima. Fui. E ela me disse: De jeito nenhum! Você é que tem talento de editor, eu não sirvo para isso! (O que, a meu ver, não era correto.) Além do mais, o salário de editor era bem maior (ela até sugeriu quanto eu devia pedir para aceitar o cargo, imagine). Insisti um bocado, mas ela insistiu mais ainda: o editor devia ser eu. E assim foi: voltei ao Noro, contei a 
resposta dela e iniciei uma carreira que tem muito pra contar. Talvez eu faça mesmo o livro que estão me pedindo a respeito, só preciso de tempo.

Bom, Wesley, contei a história só para dar noção da ética que prevalecia entre nós, que imaginávamos, ainda que em plena ditadura, construir um mundo de relações humanas mais justas e honestas que isso que estamos vendo aí. Mas tem muita gente boa ainda que vai mostrar a que veio. Confio.

Qual o motivo de a seleção dos catálogos para as coleções de livros da Abril ("Imortais", "Pensadores", Teatro Vivo, etc.) não contemplarem autores nacionais e a cultura popular, parte dela já legitimada pela crítica na época (como Ariano Suassuna, que poderia estar em Teatro Vivo), Patativa do Assaré em uma coleção de poesia... Ainda, porque a poesia nunca teve espaço nas coleções de literatura?

Boa questão, Wesley. Quanto a Teatro Vivo e Pensadores eu não saberia responder, talvez alguém da Cultural com que você tenha obtido contato saiba responder. No Círculo do Livro, lancei tanto poetas brasileiros como estrangeiros, intercalando as publicações. Havia, sim, um problema específico aí: a dificuldade em conseguir direitos autorais, e talvez isso tenha pesado lá do lado da Cultural. Levei muitos anos para conseguir Drummond e Bandeira para o Círculo, por exemplo, e o pessoal que editava para bancas não dispunha de tanto tempo. Já no que se refere aos clássicos, a questão é interessante: talvez não fosse nem consciente para nós, editores, mas se Machado de Assis e Victor Hugo, por exemplo, eram clássicos, acabavam integrados em duas categorias distintas, não a mesma: o clássico brasileiro e o clássico estrangeiro. Então, quando se falava em grandes clássicos da literatura, eram lembrados só os estrangeiros; mas quando se falava em Alencar ou em Machado, dizia-se igualmente que eram clássicos - essa é, pelo menos, a minha percepção retroativa. Assim, minha seção de clássicos no Círculo do Livro só continha autores estrangeiros; no entanto, eu editava os clássicos brasileiros na seção de Literatura Brasileira, embora que num setor especial, o de nossos clássicos. E, creio, assim têm feito todas as editoras. Tenho feito alguns trabalhos para os Clássicos Penguin da Companhia das Letras e, pelo menos na parte que me coube, até agora não vi nenhum brasileiro. Creio mesmo que não os há nesse selo, seria o caso de verificar, como índice de permanência dessa divisão (digamos, inconsciente da parte dos editores) entre os clássicos. No Círculo, fiz até uma coleção em vinte volumes à qual dei o nome de Grandes da Literatura Brasileira, e nela incluí os nossos clássicos; mas, pasme, não me ocorreu colocá-los na série de grandes da literatura mundial... 
Quanto a OS PENSADORES, é curioso que, tendo contado com José Américo Pessanha em posição de relevo na edição e com Marilena Chauí e outros filósofos brasileiros nos textos, não Ihes tenha ocorrido fazer volume com pensadores brasileiros. Tenho a lista completa da coleção, que o próprio José Américo me deu, e lá não há disso. Talvez na época, também na filosofia, como na literatura, os grandes brasileiros fossem categoria duplamente à parte: à parte dos autores brasileiros não clássicos e à parte dos estrangeiros já igualmente clássicos. 